\title{
PRODUÇÃO AUDIOVISUAL NA UNIVERSIDADE DE SÃO PAULO
}

\author{
Domingos Luiz Bargmann Netto
}

\begin{abstract}
Dissertação apresentada ao Programa de Pós-Graduação em Ciências da Comunicação da Escola de Comunicações e Artes da Universidade de São Paulo, como parte dos requisitos para a obtenção do título de Mestre na área de Cinema, Rádio e Televisão.
\end{abstract}

Orientador : Profa. Dra. Marília da Silva Franco

São Paulo - SP

Maio de 2000 


\section{Folha de aprovação}

Autor: Domingos Luiz Bargmann Netto

Título: Produção Audiovisual na Universidade de São Paulo

Dissertação defendida e aprovada em $06 / 10$ / 2000

pela comissão julgadora:

(assinatura)

Nome/ Instituição - Profa. Dra. Sheila Walbe Ornstein - FAUUSP

(assinatura)

Nome/Instituição - Profa. Dra. Vania Debs - ECAUSP

(assinatura)

Nome/Instituição - Profa. Dra. Marília Franco - ECAUSP (orientadora)

Presidente da CPGCA 
Universidade de São Paulo

Programa de Pós-Graduação em Ciências da Comunicação

\section{PRODUÇÃO AUDIOVISUAL NA UNIVERSIDADE DE SÃO PAULO}

Domingos Luiz Bargmann Netto

São Paulo - SP

Maio de 2000 


\section{Sumário}

Resumo/Abstract, pág. $0 \underline{1}$

Apresentação, pág. $0 \underline{2}$

1- A Ciência, as Tecnologias Audiovisuais e a Universidade, pág. $\underline{07}$

2- Experiências Passadas de Produção Audiovisual na USP, pág. $\underline{17}$

2.1- O Audiovisual nos Estatutos e Regimentos da USP, pág. $\underline{19}$

2.2- O Serviço de Documentação do DCAS - Departamento de Cultura e Ação Social da USP, pág. $\underline{25}$

2.3- O Clube de Cinema da Faculdade de Filosofia, Ciências e Letras, pág. $\underline{34}$

2.4- O Departamento de Produção de Filmes Documentários do IEB - Instituto de Estudos Brasileiros, pág. $\underline{35}$

2.5- O Serviço de Recursos Audiovisuais do Centro Regional de Pesquisas Educacionais "Prof. Queiroz Filho", de São Paulo, pág. $\underline{39}$

2.6- A (quase) Televisão Educativa USP/Ford Foundation, pág. $\underline{44}$

2.7- A ECA - Escola de Comunicações e Artes, pág. $\underline{48}$

2.8- O Laboratório de Recursos Audiovisuais da FAU, pág. 51

2.9- Outros casos não menos significativos, pág. $\underline{58}$

3- O Audiovisual na USP dos Anos 90, pág. $\underline{63}$

3.1- Estação Ciência, pág. $\underline{63}$

3.2- Núcleo José Reis de Divulgação Científica, pág. $\underline{65}$

3.3- Projeto UNIVÍDEO/CECAE, pág. $\underline{66}$

3.4- Fundo de Cultura e Extensão, pág. $\underline{87}$ 
3.5- Sistema Integrado de Apoio ao Ensino, pág. $\underline{89}$

3.6- Fundação de Amparo à Pesquisa do Estado de São Paulo, pág. 91

3.7- Educação Continuada a Distância, pág. 93

3.8 - TV USP - CCS, pág. 98

4- Relatos pessoais, pág. 101

4.1- Mario Guidi, pág. 101

4.2- Claudio Zaki Dib, pág. 112

4.3- Cristiano Mascaro, pág. 115

5- Os Problemas da Produção de Vídeo na USP, pág. 122

5.1- Recursos Humanos, pág. 122

5.1.1 - Composição de uma Equipe de Vídeo, pág. 123

5.1.2 - Formação Profissional, pág. 125

5.1.3 - Plano de Classificação de Funções na Área do Audiovisual, pág. 127

5.1.4 - Cooperação na Produção, pág. 128

5.2- Equipamentos e Tecnologia de Produção de Vídeo, pág. 129

5.2.1 - Processo de Compra, pág. 129

5.2.2 - Cooperação Técnica Interunidades, pág. 131

5.2.3 - Infra-estrutura Física, pág. 132

5.3 - Processo de Produção de Vídeo, pág. 133

5.3.1 - Formatos Audiovisuais, pág. 133

5.3.2 - Planejamento, pág. 136

5.3.3 - Custos de Produção, pág. 137

5.3.4 - Distribuição e Divulgação, pág. 138

5.4 - O Pensamento Científico e o Audiovisual, pág. 139 
6- Conclusões, pág. 144

7- Bibliografia, pág. 149

8- Anexo I - Decreto de fundação da Universidade de São Paulo (cópia parcial do texto do documento), pág. $\underline{152}$

Anexo II - Documentos relativos à reorganização do DCAS - Departamento de Cultura e Ação Social, pág. $\underline{155}$

Anexo III - Documentos relativos à TV Educativa USP/Ford Foundation, pág. $\underline{160}$

Anexo IV - Carta enviada ao Departamento de Recursos Humanos da USP, pág. 177

Anexo V - Descrição de atividades na produção de vídeo, pág. $\underline{180}$

Anexo VI - Projeto de Capacitação de Docentes enviado ao Departamento de Recursos Humanos da USP, pág. $\underline{184}$

Anexo VII - Funções do Plano de Carreira dos funcionários da USP compatíveis com produção de vídeo, pág. $\underline{193}$

Anexo VIII - Tipos de equipamentos para produção de vídeo, pág. 198 


\section{$\underline{\text { Resumo }}$}

Esta dissertação enfoca os aspectos práticos da produção audiovisual, destacadamente em vídeo, no ambiente acadêmico da Universidade de São Paulo.

A universidade como ambiente onde se desenvolve a Ciência, através da pesquisa, e se reproduz o pensamento científico, através do ensino, é também um ambiente propício às atividades do audiovisual. O avanço científico dos séculos XIX e XX permitiram a criação de tecnologias da imagem e do som, desde a fotografia aos WEB sites, que tão profundamente marcam o mundo contemporâneo. Por sua vez, estas mesmas técnicas muito contribuíram para os desdobramentos das pesquisas científicas, com a telescopia, a microscopia e demais sistemas de análise do espectro.

A Universidade de São Paulo, em mais de 60 anos de história, abrigou diversas iniciativas de produção de filmes e vídeos vinculados a atividades de ensino, pesquisa e extensão. Procuramos resgatar experiências passadas e verificar as atuais condições de produção de vídeos na USP. Nesse levantamento detectamos algumas constantes que indicam a necessidade de se estabelecer políticas para o audiovisual na Universidade.

Palavras-chave: audiovisual; cinema; documentário; história da USP; televisão; Universidade de São Paulo, vídeo.

\section{$\underline{\text { Abstract }}$}

This thesis focuses the audiovisual production pragmactical aspects mainly the video one wich is being made in the University of São Paulo (USP) academic environment. The University as an environment where Science is developed, throughout research and it reproduces the scientific thinking throughout education, it is also a fertile environment to audiovisual activities. Along the $19^{\text {th }}$ and the $20^{\text {th }}$ centuries, the scientific progress made possible the creation of sound and image technologies, since photo til WEB sites, wich so deeply enlightened the contemporany world. By the turn, these same techniques contribute to development of the scientific researches such as the telescopy, the microscopy and the other systems of the lighting spectrum analyses. The USP, along its 60 years old history, sheltered many production of films and videos linked to teaching, research and extension activities. We enlightened not only past experiences but also the up-to-date conditions of video production in USP. This survey shows same constant issues wich to the need of audiovisual policies in the Universiy.

Keywords: audiovisual, audiovisual policies, cinema documentary, history of the University of São Paulo, University of São Paulo, television, video. 


\section{$\underline{\text { Apresentação }}$}

Venho trabalhando na produção de vídeo documentários há 15 anos, primeiro na UNICAMP - Universidade Estadual de Campinas, de 1983 a 1986, e depois, a partir de 1987, no VídeoFAU - Laboratório de Vídeo da FAU - Faculdade de Arquitetura e Urbanismo da USP - Universidade de São Paulo.

No início eu participava de um grupo voluntarioso, coordenado por Marcelo Costa Souza, que se empenhava na produção de vídeos científicos. Era o embrião do que viria a ser o Centro de Comunicações da UNICAMP. Lá, meus primeiros trabalhos foram na área médica. Montávamos um circuito fechado de TV com duas câmeras transmitindo as cirurgias do Prof. Dr. José Aristodemo Pinotti. Eram mastectomias radicais, para um grupo de alunos instalados no anfiteatro do hospital. Como experiência técnica em sistemas de vídeo e áudio, havia intercomunicação entre equipe médica e alunos. Foi muito válido, mas logo busquei áreas mais amenas.

Certa ocasião fomos documentar uma comunidade de quilombolas, em Cafundó próximo a Sorocaba, São Paulo, junto com o Prof. Dr. Carlos Vogt, e tivemos que sair às pressas do lugar, pois uma série de mal entendidos entre a nossa equipe, mal preparada para um trabalho sócio-antropológico, e a população local, ressentida pelo freqüente assédio da imprensa e de pesquisadores, gerou um clima de animosidade que inviabilizou um bom relacionamento. Em outra ocasião, numa gravação da peça Pedro e o Lobo, nossa equipe ficava aguardando (im)pacientemente, por várias madrugadas seguidas, as discussões em torno dos imperativos da linguagem da dança sobre as especificidades da linguagem audiovisual travadas pela coreógrafa, a Profa. Marília de Andrade, e o cineasta Nuno Cesar de Abreu, que fazia a direção de vídeo, ambos do Instituto de Artes da UNICAMP. Eu estava aprendendo que fazer vídeos não era só lidar com equipamentos. Nesses tempos a minha ocupação principal era com a câmera, foi pela imagem que entrei nessa área.

Quando aluno de graduação do Departamento de Geografia da FFLCH/USP, em 1976, fiz também um curso de fotografia. Na minha cabeça as duas coisas se juntavam, o estudo do espaço geográfico com a observação e a apreensão do espaço fotográfico. $\mathrm{Na}$ prática profissional era bem difícil fazer essa junção, o mercado da fotografia é 
especializado e não permite experimentações, ou é a publicidade ou o foto-jornalismo e as áreas editoriais. Como nenhuma dessas atividades me atraía segui um caminho pessoal, fotografava meu ambiente, minha vida e lecionava geografia em escolas públicas.

Em 82 recebi uma proposta de documentar as atividades de pesquisas na área de Pedagogia, na UNICAMP, atividades coordenadas pelas Profas. Dras. Regina de Assis e Ana Luiza Smolka, daí vem a minha entrada no mundo acadêmico, trabalhando em documentação visual, primeiro com fotografia e depois com vídeo.

Na UNICAMP e na USP realizei documentários em diversas áreas do conhecimento - Antropologia, Medicina, Física, Pedagogia, Artes Plásticas, Arquitetura e sempre fiquei impressionado com o pouco uso que as universidades fazem dos recursos da comunicação audiovisual nelas existentes - equipamentos de vídeo e técnicos especializados. Além disso, a Universidade como depositária e guardiã dos saberes e como geradora de novos conhecimentos tem muito a contribuir numa sociedade carente de valores da crítica, da cidadania e o vídeo é, simplesmente, mais um recurso de comunicação para ser posto a serviço das demandas sociais.

O ambiente das universidades públicas apresenta características de organização e burocracia que influenciam fortemente o trabalho de produção audiovisual ${ }^{1}$. São vários os fatores que interferem nos procedimentos de trabalho e marcando o aspecto final dos filmes e vídeos. O uso de verbas públicas tem normas que exigem uma prestação de contas detalhada e documentada, onde um gasto do tipo "pagamento ao barqueiro Ubiratan por serviço de transporte fluvial, no rio Ribeira de Iguape, no trajeto de Iporanga à Prainha, para registro de depoimento de Dª . Clotilde”, como foi necessário na produção do documentário "Taipa de mão, casa de caboclo" que o VídeoFAU realizou em 1997, não seria aceito sem documentação. Ora, o Ubiratan não tem CPF e muito menos nota fiscal, ou utilizávamos os seus serviços ou não faríamos a gravação com a D . Clotilde.

\footnotetext{
${ }^{1}$ Na prática profissional a expressão 'audiovisual', nos anos 70, designava o sistema de projeção de slides acompanhada da reprodução de uma fita de áudio, com apenas um projetor ou, nas produções mais sofisticadas, chamadas multivisão, com 12 projetores simultâneos. Com o advento do videocassete e das videocameras esse sistema caiu em desuso e a expressão 'audiovisual' também. As novas tecnologias, digitais e multimídia, recuperaram a expressão e audiovisual, hoje, representa um conceito de amplo espectro de atividades relacionadas à produção e criação de imagens e sons.
} 
É comum o ar de surpresa nas pessoas que, indagando qual o meu trabalho, ficam sabendo que a FAU - Faculdade de Arquitetura e Urbanismo da USP tem uma produção de documentários e que esses programas estão sendo assistidos em diversas escolas de arquitetura e de engenharia espalhadas pelo país e, vez por outra, são exibidos na TV Cultura e na TV USP. Alguns desses vídeos, nos quais faço a direção e coordeno a produção, já receberam premiações em mostras e festivais de documentários. $^{2}$

Não só a FAU, mas a Universidade de São Paulo tem, sim, uma produção audiovisual e tem também uma história de uso de recursos do cinema, da televisão e do vídeo. História fragmentada, com documentação dispersa, de difícil resgate, dependendo da coleta de depoimentos pessoais. Ao longo de seus 65 anos de existência várias experiências aconteceram permitindo-nos afirmar que a análise da produção audiovisual na USP é reveladora das relações entre o ambiente acadêmico e as práticas da comunicação. A partir do conhecimento dos trabalhos realizados e do contexto da sua produção é possível apontarmos os problemas e as virtudes que esta instituição tem para, utilizando os recursos do vídeo, ampliar seu espaço nesses tempos de sociedade televisiva.

É sobre as questões em torno da produção audiovisual na Universidade de São Paulo que desenvolvi esta dissertação de Mestrado. O fantástico mundo contemporâneo em que vivemos, onde espaço e tempo são expressos em megabytes e megahertz, onde as tecnologias de recepção e de produção de imagens e sons invadem nossos eletrodomésticos, é decorrente do rápido desenvolvimento científico e tecnológico dos últimos dois séculos. Do relógio digital ao telefone celular, foram cientistas e pesquisadores que criaram as bases técnicas para a atual sociedade de informação. Sem uma rede de computadores de comunicação instantânea isso seria possível? E a ciência

\footnotetext{
${ }^{2}$ Em 1992 a série de documentários sobre a construção do MUBE Museu Brasileiro da Escultura recebeu o prêmio IAB - Vídeo de Arquitetura, no evento Encontro das Américas promovido pelo Instituto de Arquitetos do Brasil/São Paulo; em 1996 o vídeo "Esculturas Lúdicas" recebeu uma menção honrosa no $10^{\text {th }}$ IFHP International Housing and Planning Film/Video Competition, no Japão; em 1998 o documentário "Taipa de mão, casa de caboclo" também recebeu uma menção honrosa no $11^{\text {th }}$ IFHP, em Portugal e, na II Mostra de Vídeo do MIS Museu da Imagem e do Som de São Paulo, recebeu o prêmio de melhor vídeo universitário.
} 
sem as imagens micro/macroscópicas, sem a captura do instante preciso, onde estaria a engenharia genética e outras tantas inovações científicas?

A Universidade é um ambiente privilegiado para o audiovisual fluir naturalmente, como mais uma atividade das pesquisas e de ensino, e seria também o ambiente apropriado para a discussão do papel e das transformações que as linguagens audiovisuais têm operado na sociedade contemporânea. Tais questões serão abordadas no primeiro capítulo.

Nessa perspectiva a Universidade de São Paulo teria abrigado propostas e realizações de filmes, de vídeos, de televisão no decorrer de sua história. O levantamento de experiências de produção audiovisual, do passado até o presente, é apresentado nos capítulos segundo e terceiro. Essa pesquisa buscou informações em documentações oficiais da Universidade, nos arquivos da Reitoria, nas publicações sobre a história da instituição e, sempre que possível, procurei complementar e verificar os dados coletados mediante a coleta de depoimentos de personagens atuantes nos casos relatados. Tais depoimentos foram registrados em fita de áudio e são apresentados conforme a sua transcrição, mantendo o aspecto coloquial.

A riqueza desses depoimentos, registrando trajetórias de vida e diferentes formas de pensar o audiovisual na Universidade, levaram-me a inserir um capítulo específico para que tais experiências e conhecimentos se manifestassem mais plenamente. São visões de três profissionais de áreas distintas, um psicólogo, um físico e um arquiteto ${ }^{3}$, comentando sobre sua prática de trabalho e sobre o papel das imagens e dos sons no ambiente acadêmico. Com isso encerro o levantamento de dados e inicio os comentários dos problemas da produção de vídeos na USP, o quinto capítulo.

A abordagem dos problemas de produção considera todo o material já apresentado e minha vivência de 15 anos como vídeo produtor na Universidade, além da reflexão decorrente das atividades de pós-graduação que realizei. Nesta etapa procuro detalhar os diversos aspectos envolvidos na produção audiovisual, os procedimentos, as

\footnotetext{
${ }^{3}$ São eles, respectivamente: o Prof. Dr. Mario Guidi, o Prof. Dr. Claudio Zaki Dib e o fotógrafo Cristiano Mascaro.
} 
necessidades, as limitações e as contradições, quando realizada no ambiente da universidade pública.

O sexto capítulo resgata uma valiosa discussão ocorrida em 1994 no Centro Universitário Maria Antonia, o Seminário Internacional Dez anos de Ciência na $T V,{ }^{4}$ de onde partiram propostas pertinentes aos nossos interesses presentes. Nesse momento faz-se necessário um questionamento sobre os rumos das atividades de vídeo produção na universidade, da perspectiva adotada na sua realização para então apresentar as conclusões pertinentes.

Esta dissertação tem origem numa insatisfação com a repetição constante de algumas situações no meu trabalho de produção de vídeo na universidade. Verifiquei que são problemas comuns a vários profissionais da área e de várias épocas e me propus a escrever sobre isso. Portanto, é um levantamento comentado das práticas, das realizações (ou das não realizações) e, no anseio da superação de limites, propõe alguns caminhos. Acredito que a USP tem um desafio no mundo contemporâneo - criar uma nova imagem, não como a casa do saber, esta já está consolidada, mas como uma usina geradora de crítica e de novas práticas da cultura audiovisual/informatizada nesta passagem de milênio.

${ }^{4} \mathrm{O}$ evento foi organizado pelo UNIVÍDEO/Cecae/USP e teve a participação de representantes da BBC, de Londres, da Rede POP/UNESCO, da TV da Venezuela, da Academia Brasileira de Ciências, da Fundação Roberto Marinho, da UNESP, da UFPA, da UnB, unidades da USP (HRB, IQ, FAU, ECA, IF, CECAE), as empresas Mediatech e Vídeociência, do Rio de Janeiro e o, então pró-reitor de Cultura e Extensão, Jacques Marcovitch. 


\section{1 - A Ciência, as Tecnologias Audiovisuais e a Universidade}

"O cinema nasce científico para depois tornar-se espetáculo."

Essa abordagem, da natureza científica do cinema, é extremamente atraente para o escopo desta dissertação. Dado que sua origem está inserida em experimentações científicas e também que foi um valioso instrumento para o avanço das ciências, caberia ao cinema um lugar de destaque na instituição de excelência da pesquisa e do ensino em seu mais alto nível - a Universidade.

Não só por sua fundamentação teórica e técnica, baseada no conhecimento de médicos, engenheiros, físicos e químicos dos meados do séc. XIX, mas principalmente pela intenção de seus inventores em obter um novo instrumental de observação e registro de dados, o cinema é, primeiro, uma realização da ciência.

A ciência precisava do cinema e o cinema, para existir, precisava de um conjunto de conhecimentos científicos. Podemos encontrar a intenção de registro do movimento em outros meios de representação visual, mas o caráter documental da fotografia e a precisão mecânica no controle do tempo não poderiam prescindir dos conhecimentos e técnicas que só estariam disponíveis, no seu conjunto, no decorrer do séc. XIX. As grandes realizações não são obra de gênios iluminados. A estes ocorrem visões que, muitas vezes, aguardam séculos para se tornarem realidade. Da Vinci teve grandes idéias, mas estava defasado das técnicas capazes de materializá-las.

Historicamente há um extenso elenco de personalidades que compartilharam das idealizações e tentativas de solucionar a questão de dar movimento às imagens, mas Etiènne-Jules Marey e Eadweard Muybridge despontam como principais autores da técnica cinematográfica.

E. J. Marey, médico francês com vocação de engenheiro, preocupava-se inicialmente com problemas de fisiologia e desenvolveu aparelhagens para a representação gráfica de funções vitais e movimentação de animais.

\footnotetext{
${ }^{5}$ Comentário do Prof. Dr. Mário Guidi em depoimento coletado pelo autor em setembro de 1999.
} 
“Como todo pesquisador, Marey é movido por dois impulsos básicos: obter o máximo de dados com os recursos instrumentais e metodológicos conhecidos e, ao mesmo tempo, buscar recursos instrumentais novos, que permitam ampliar a gama e a precisão dos dados necessários ao avanço da pesquisa."

A publicação de seus estudos, em dezembro de 1878, alcançou repercussão internacional, estimulando outras experiências correlatas. Nos E.U.A., Lelland Stanford, fundador da universidade homônima contrata o fotógrafo Eadweard Muybridge para experimentarem a técnica fotográfica no registro do trote de um cavalo. São ainda fotografias, mas capturam momentos seqüenciais do movimento.

Marey e Muybridge trocam correspondência, seus trabalhos se aproximam e se complementam, os dois não serão parceiros, um é cientista o outro um inventivo fotógrafo. Cada um, por métodos e propósitos próprios, desenvolve equipamentos e dispositivos para resolver uma série de questões sobre o fracionamento do movimento em momentos distintos, numa elaborada articulação de engenharia eletro-mecânica, física ótica e química. Ambos alcançaram bons resultados, Marey com a cronofotografia e Muybridge com suas câmeras interligadas, realizaram os primeiros registros analíticos do movimento com precisão.

A etapa seguinte, da síntese reconstrutiva do movimento registrado, encontrou embasamento técnico em vários experimentos precedentes. Mecanismos de projeção de imagens animadas eram conhecidos há muito tempo, do singelo teatro de sombras chinês à popular lanterna mágica e, no decorrer do séc. XIX, surgiram novos aparelhos dando movimento a desenhos e silhuetas.

Baseado no fenômeno da persistência da imagem na retina ${ }^{7}$, a simulação do movimento era obtida por uma variedade de dispositivos - panoramas móveis, diorama,

\footnotetext{
${ }^{6}$ Guidi, Mário. De Altamira a Palo Alto. Tese de Livre Docência, São Paulo, ECA/USP, 1991.

${ }^{7}$ Conforme o trabalho do Prof. Dr. Mario Guidi, já citado, "O fenômeno é conhecido desde há muito. Tito Lucrezio Caro dele fala em seu De Rerum Natura, no ano 65 a.C. Ptolomeu, Newton e vários estudiosos a ele se referem ao longo dos séculos. Cabe porém a Peter Mark Roget em 1825, uma definição mais precisa e científica. Neste ano ele apresentou a Royal Society of London um trabalho onde explicava a relação entre a persistência da imagem na retina e a ilusão de óptica da síntese do movimento, ... De acordo com Plateau, este fenômeno teria, no olho humano, duração de 1/10 de segundo. Apesar de aproximado, esse dado serviria de base aos construtores dos primeiros aparelhos cinematográficos, onde a freqüência de projeção era da ordem de 16 quadros por segundo. Hoje, pesquisas realizadas na área da neuropercepção e psicologia sensorial nos fornecem um quadro mais amplo e preciso. A freqüência necessária, para que o olho humano perceba, como contínuo, um estímulo luminoso intermitente
} 
taumatrópio, fenaquitoscópio, zootrópio, praxinoscópio e outros. Muybridge desenvolveu seu aparelho projetor, o zoopraxiscópio, e obteve resultados plenamente satisfatórios. A primeira apresentação ocorreu em 1880 na San Francisco Art Association, e em outubro de 1881 realiza uma demonstração no Laboratório de Marey, em Paris.

A questão da autoria de um invento é, em geral, motivo de controvérsias. Não sendo um evento isolado e sim um processo cumulativo de conhecimentos e técnicas, concorrem a ele todos os outros pesquisadores que tenham contribuído, direta ou indiretamente, à solução final. Marey, como cientista, desinteressado de finalidades comerciais, é a figura que deu os passos principais nessa história, mas são seus coadjuvantes que levarão a fama da invenção do cinema.

A partir da $1^{a}$ sessão pública em dezembro de 1895 , pelas mãos dos irmãos Lumière, o cinema segue como que uma continuidade de seus objetivos primeiros registrar o movimento. Pode-se dizer que, além de científico, o cinema passou a ser educativo, tais as imagens produzidas pelos cinegrafistas dos Lumière, enviados aos mais diversos países, a recolher vistas do cotidiano, de eventos sociais e culturais. As cenas apresentadas eram, e continuam sendo, documentos que trazem ao público uma impressão dos costumes e comportamentos de outros povos, ampliando o conhecimento da diversidade cultural, social, geográfica, do mundo.

“Ao ver de vários estudiosos, a história do cinema documental e a do cinema educativo se confundem, no exterior e no Brasil. Referindo-se aos 15 primeiros anos da história do cinema, Elliot (1948) diz que o público que pagava para entrar nas salas de exibição de filmes 'divertia-se e, ao mesmo tempo, era educado" graças a películas do tipo documental." 8

O cinema logo será usado como material educativo. Em 1898 o médico francês Dr. Doyen registra em película uma de suas operações para finalidades de ensino. $\mathrm{Na}$ primeira década do séc. XX educadores e pesquisadores dedicam-se a discutir, produzir e aperfeiçoar a produção de filmes educativos, "por volta de 1910, catálogos

(Freqüência Crítica de Fusão), depende da intensidade luminosa do estímulo apresentado, bem como do nível de iluminação do ambiente onde se encontra o observador."

${ }^{8}$ Pfromm Netto, Samuel. Telas que ensinam. Campinas, SP, Editora Alínea, 1998. 
especializados de filmes educativos eram disponíveis nos EUA, na França e na Inglaterra. Um catálogo de uma firma de Chicago, por exemplo, listava mais de mil títulos, destinados às escolas e ao ensino em geral." 9

A Medicina apropriou-se da técnica do cinema incorporando-a ao seu instrumental clínico, primeiro como registro de sintomas e tratamentos e, em seguida, desenvolvendo novos instrumentais para o exame interno do corpo. A sofisticação dos recursos de microcinematografia, endoscopia, filmagem em câmera lenta, registro em infra-vermelho, ultra-violeta e raios $\mathrm{X}$ permitiram à ciência imagens de fenômenos nunca antes verificados, não só na área médica, mas também na astronomia, na meteorologia, na psiquiatria, constituindo propriamente o cinema científico.

O período da II Guerra Mundial representa o principal momento de expansão do uso do cinema para fins de ensino e treinamento. Os Estados Unidos precisavam preparar milhares de pessoas para o esforço de guerra, nas fábricas de material bélico, nos serviços médicos, nas comunicações, nas operações de guerra, "O programa planejado para a solução deste problema desenvolveu-se tendo como centro os recursos audiovisuais. Somente para esse fim, o exército americano adquiriu 55.000 projetores e gastou cem milhões de dólares em filmes educativos. "10 Nessa operação participaram, inclusive, educadores que já trabalhavam em universidades, na administração escolar, nas políticas educacionais do país, e que puderam, então, experimentar e verificar os resultados do uso intensivo do cinema no processo ensino/aprendizado.

Com o sucesso alcançado pelas Forças Armadas Americanas, os educadores foram estimulados a fazer o mesmo nas escolas. Os recursos audiovisuais invadem as salas de aula, refletindo o interesse das indústrias de equipamentos num mercado ainda inexplorado. As universidades passam a formar mais especialistas nesses recursos e a treinar professores no seu uso, o governo investe em pesquisas pedagógicas. A partir desse momento as escolas e a educação iniciam um processo de renovação baseado, principalmente, no uso de tecnologias da imagem e do som.

\footnotetext{
${ }^{9}$ Id. Ibid.

${ }^{10}$ Parra, Nelio. Recursos Audiovisuais e a Renovação Didática. Tese de Doutorado, São Paulo, FE/USP, 1972.
} 
Nos anos 60, estudos verificam que a educação é o principal fator para a melhoria do desempenho econômico de uma nação e, também, que nos países de economia pouco desenvolvida as escolas são precariamente aparelhadas e utilizam métodos de ensino arcaicos ${ }^{11}$. Os professores deveriam ser equipados com os modernos recursos audiovisuais e, com isso, elevar o padrão de qualidade do ensino num salto, arrancando os países pobres de sua permanente estagnação econômica. Como plano de marketing para as indústrias do ramo e como forma de expandir a ideologia do capitalismo americano funcionou bem, mas para os problemas da escola de nada adiantou, ou melhor, acirrou algumas das contradições,

“..., apesar da introdução de novos instrumentos e recursos tecnológicos no ensino, em essência o sistema em nada mudou. Continuou a ser encarado como uma transmissão de informações por parte de um professor, agora com uma bagagem maior de recursos e equipamentos, para um grupo de alunos em geral, passivos. E levantamos a hipótese de que o sistema não se modificou, porque suas bases, apesar de ultrapassadas, teoricamente falando, continuaram a dirigir, no dia-a-dia escolar, a utilização daqueles recursos." 12

Fora da escola, e apesar dela, o mundo corria em direção oposta. Não só o cinema, mas também novos meios de comunicação interagiam rapidamente com a sociedade, espalhando sua presença nas artes, na cultura, na economia, na política. Marconi, no final do séc. XIX, apresentava a radiotransmissão e, durante a I Guerra Mundial, várias indústrias aperfeiçoaram os equipamentos de rádio. Em 1920, a empresa americana Westinghouse, ainda com muitos aparelhos em seu estoque, realiza transmissões de entretenimento em Pittsburgh. O rádio ganha uso comercial estimulando a formação de indústrias do setor, do mercado publicitário e da própria indústria da comunicação.

Paralelamente, ainda no final do séc. XIX, foram desenvolvidas pesquisas para a obtenção de técnicas de transmissão instantânea da imagem e na década de 1920 os

\footnotetext{
${ }^{11}$ Id. Ibid.

${ }^{12}$ Id. Ibid.
} 
resultados já eram satisfatórios. ${ }^{13}$ As primeiras transmissões de televisão ocorrem na Inglaterra em fins de 1936, pela BBC de Londres.

As emissoras de rádio e televisão organizaram-se de formas distintas quanto a seus propósitos. Na Europa, desde o início, foram consideradas como serviços públicos com finalidades de veicular os valores culturais do país, oferecer informações de interesse geral da população e, portanto, não poderiam sofrer interferências de caráter comercial ou político. Estavam, assim, inseridas na mesma esfera de atividades que as universidades e museus, como elementos de cidadania a serviço da nação. Na América ocorreu o oposto, as empresas privadas dominaram o setor e as emissoras públicas foram apenas complementares ao sistema.

A II Guerra Mundial impediu a rápida difusão da TV, principalmente na Europa, mas após esse período de estagnação, a expansão das emissoras avança pelo mundo inteiro. Com a melhoria da qualidade de transmissão e a ampliação da área de recepção, a TV passa à hegemonia nos meios de comunicação.

A tecnologia do vídeo desenvolveu-se a partir dos mesmos princípios do registro sonoro em suporte magnético e dos processos de captação e reprodução de imagens da televisão. Nos anos 50 surge a fita magnética (videotape) para armazenar imagens e permitir a exibição de programas pré-gravados. Os processos técnicos utilizados têm seus antecedentes no sistema de gravação sonora já industrializado desde 1935 pela empresa alemã AEG. Na década de 60 os aparelhos de videotape portáteis vão substituir as câmeras de cinema de $16 \mathrm{~mm}$, que eram utilizadas na cobertura jornalística e agilizam os trabalhos de reportagens externas. Nos anos 70 essa tecnologia chega ao consumidor doméstico em câmeras e gravadores do tipo Betamax e VHS. Em pouco tempo torna-se hábito assistir a filmes em fitas de vídeo alugadas.

Com a facilidade de manuseio do videocassete a exibição de materiais educativos em sala de aula ganha um novo impulso. Empresas especializam-se na

\footnotetext{
${ }^{13}$ A relação entre luz e eletricidade, o efeito foto-elétrico, era conhecido desde 1817 (Berzeleus, Suécia) a partir da propriedade do elemento Selênio. Em 1873, produziu-se a primeira célula fotocondutora (W. S. May, Inglaterra). Em 1884, Paul Nipkow, estudante de Ciências Naturais em Berlin, criou um sistema de decomposição da imagem e no ano de 1923, é patenteado o tubo de raios catódicos, pelo engenheiro e físico russo W. Zworikin. Em 1926, o inglês J. L. Baird demonstra a televisão no Royal Institution e a BBC passa a apoiar o desenvolvimento desse sistema.
} 
transposição de filmes didáticos para fitas magnéticas (o processo de telecinagem), investindo no mercado educacional apoiadas na nova tecnologia. A popularização do vídeo desencadeou um processo que vem transformando a cultura audiovisual, facilitando o acesso a filmes de cinema, possibilitando a gravação de programas da TV e, principalmente, com as câmeras de uso doméstico, as pessoas estão desenvolvendo uma noção do fazer audiovisual, do manuseio das imagens e sons, antes inviável aos leigos pela complexidade da indústria cinematográfica e da televisão e pelos custos proibitivos dos meios de produção.

Desde meados do séc. XIX até a primeira metade do séc. XX preparou-se o cenário para as grandes mudanças que vão ocorrer, principalmente, adiante dos anos 50. Um outro elemento fundamental desse cenário surge na década de 40 , quando o primeiro computador entra em funcionamento na Inglaterra. ${ }^{14} \mathrm{Com}$ a invenção de novos dispositivos eletrônicos, o transistor (1947), o circuito integrado (1959), o computador torna-se a peça central da revolução tecnológica que estamos vivendo. Inicialmente projetado para finalidades científicas e de desenvolvimento tecnológico, a presença do computador se multiplica a partir dos anos 70, no comércio, na administração pública e nos lares, com o uso de programas de cálculo, de planilhas, de textos, de jogos de lazer. O grande aliado do uso amplo do computador dá seus primeiros passos também nos anos 70. Na década anterior o Departamento de Defesa dos Estados Unidos havia desenvolvido uma rede de comunicação interligando computadores dedicados a estratégias militares (ARPANET). Como os Centros de Pesquisas, as Universidades e os Laboratórios de empresas privadas tinham a necessidade de troca de informações em fluxos cada vez maiores, passaram a usar o sistema de redes de computadores com múltiplas conexões. Desta forma, cientistas e demais pesquisadores passaram a intercambiar informações, dados e arquivos, por todo o planeta, pois os computadores de uma Universidade, formando uma rede, podem se comunicar não apenas com uma outra rede, mas com muitas outras, de seu próprio país, de seu continente, do mundo. A INTERNET surge para servir às pesquisas científicas e tecnológicas, porém seu potencial de comunicação desperta o interesse geral e logo surgem empresas vendendo o serviço de conexão à rede, tanto para quem oferece quanto para quem procura informação.

\footnotetext{
${ }^{14}$ Em 1943, o computador Colossus foi produzido no Centro de Pesquisas de Bletchley Park com projeto idealizado por Max Newman.
} 
$\mathrm{O}$ aspecto que interessa destacar nesse pequeno resumo histórico é de que as atuais tecnologias da comunicação estão, todas, fundamentadas no avanço científico e tecnológico desencadeado a partir do século XIX e que as ciências conseguiram inúmeros benefícios com o uso dos recursos de processamento de imagens, de sons, de dados alfa-numéricos e das facilidades na transmissão/recepção das informações. Portanto, seria natural que as universidades apresentassem um ambiente impregnado de sistemas multimídia e demais tecnologias da imagem e do som, nas suas atividades mais avançadas e nas mais prosaicas. Seria uma vocação da universidade, o pensar e o fazer audiovisual? Isso ocorreu-me durante a leitura da Tese de Doutorado de minha orientadora, Profa. Dra. Marília Franco, quando coloca:

\footnotetext{
“A vocação é o eixo central deste trabalho. O termo remete à idéia de um conjunto de tendências e aptidões que predispõe ao cumprimento de funções e objetivos determinados. Uma vez reconhecida uma vocação, no entanto, é preciso alimentá-la de estímulos e condições para que se desenvolva". ${ }^{15}$
}

Marília Franco trata das relações entre a educação e o cinema, "buscando pontos em comum no conjunto de tendências que os orientam e de objetivos que soem cumprir”. Entendo que essa abordagem pode ser aplicada às relações entre a universidade e os recursos audiovisuais. A universidade em suas atividades de pesquisas científicas, de ensino de graduação e de pós-graduação e na extensão do conhecimento e da cultura à sociedade não só pode como deve utilizar dos recursos audiovisuais para alcançar suas finalidades. E, tratando-se de tais recursos, que na atualidade envolvem as várias mídias, fotografia, cinema, vídeo, CD-ROM, internet, cabe destacar as possibilidades e as qualidades que os recursos do vídeo oferecem.

O vídeo facilita a integração das mídias anteriores. Podemos transportar para o sinal eletrônico de vídeo todos os outros suportes visuais, gerando um efeito de aproximação das diversas formas de pensar e fazer imagens e sons. Essa facilidade dilui as fronteiras, as regras das outras linguagens, cria um espaço de expressão onde tudo é permitido. A apropriação dessa tecnologia pelas pessoas desejosas de uma expressividade audiovisual, no mundo inteiro e a partir dos anos 70, gerou uma nova articulação das imagens e sons, uma linguagem videográfica, específica do vídeo. Mas

\footnotetext{
${ }^{15}$ Franco, Marília da Silva. Escola Audiovisual, Tese de Doutorado, São Paulo, ECA/USP, 1987.
} 
ainda é uma tecnologia vinculada a processos mecânicos e analógicos e o vídeo, na sua fruição, permanece preso ao tempo, não escapa de sua linearidade, de sua finitude, há sempre um começo, meio e fim. Permanece assim como alguma coisa do passado, das formas tradicionais das linguagens audiovisuais, mas aponta para o futuro, indicando uma direção, por onde vão as novas mídias, estas sim, amparadas pelas tecnologias digitais, pelas telecomunicações e pela informática, que permitem, cada vez mais uma comunicação interativa.

É interessante observarmos que logo no início dos anos 70 várias propostas fomentam a organização de TVs Comunitárias na América do Norte. Já em 1969, George Stoney ${ }^{16}$ implantou no National Film Board do Canadá um programa de capacitação para produção de vídeos, voltado para quaisquer pessoas interessadas em realizar seus próprios programas. Negando o aparato sofisticado da televisão profissional, Stoney propunha o uso de câmeras simples como instrumento de uma comunicação alternativa, expressão da individualidade ou da coletividade, iniciando um movimento que levou à criação das TVs de acesso público, dedicadas aos interesses da comunidade.

A apropriação espontânea e criativa da tecnologia do vídeo questionou um dos grandes e incômodos paradigmas da produção audiovisual, a qualidade técnica. Sempre ameaçador o quesito de qualidade técnica inibia os desejos de indivíduos e de grupos sociais, pois implica em altos custos e maior especialização dos usuários para a operação dos equipamentos. O uso disseminado de câmeras e de sistemas de edição de baixo custo mostraram que a força da mensagem e a qualidade narrativa podem se impor sobre a parafernália técnica e atingir uma significação política e social inexistente nas grandes empresas de comunicação.

Porém, a perspectiva transformadora do vídeo na sua amplitude maior foi apontada por Mauro Cavalletti, em sua Dissertação de Mestrado "Expressão Audiovisual"17, com toda a pertinência ele coloca que,

\footnotetext{
${ }^{16}$ George Stoney, documentarista e defensor do uso da tv pela comunidade, é professor da New York University.

${ }^{17}$ Cavalletti, Mauro. Dissertação de Mestrado, São Paulo, ECA/USP, 1999.
} 
“..., o vídeo estabeleceu-se com autonomia, apresentando os sinais claros de uma estrutura tecnológica diferenciada, uma linguagem em desenvolvimento com características distintas e, finalmente, apresentando possibilidades e soluções para novas abordagens cognitivas. O vídeo reinventou eletronicamente suas matrizes e em sua posterior interface com os computadores, reinventou a si próprio, distorcendo, fragmentando, manipulando, questionando e transformando todas as mídias que incorporava em sua linguagem."

“O vídeo estabeleceu as conexões necessárias entre a mídia audiovisual da indústria e as imagens e sons irreais e sintéticos produzidas pela cultura digital. O caminho estabelecido entre dois diferentes paradigmas de comunicação, o da sociedade industrial e o da sociedade de informação, no audiovisual, tem o vídeo como passagem e principal canal de comunicação."

A partir destas considerações pretendo agora verificar quais foram as práticas desenvolvidas na USP em torno do uso dos recursos audiovisuais. 


\section{$\underline{2 \text { - Experiências passadas de producão audiovisual na USP }}$}

No início das pesquisas que realizei para esta dissertação fui encontrando informações que me levaram a crer que esta Universidade tem um passado rico em experiências de produção de cinema, televisão e vídeo, e que por terem sido descontinuadas, são pouco conhecidas.

A curiosidade de encontrar coisas que estão esquecidas por aí, em algumas páginas dispersas, descobrir imagens do passado em algum fundo de gaveta e trazê-las de volta à vida, foi uma grande motivação para essa investigação do passado. É claro que, para alcançar o objetivo do meu mestrado, não poderia deixar de registrar experiências anteriores de produção audiovisual e juntando-as ao conhecimento do presente, apresentar um quadro comentado da produção de cinema e vídeo na Universidade de São Paulo, que é o que interessa a este trabalho.

Em diversos momentos a vontade de aprofundar a pesquisa histórica era forte, principalmente quando encontrava um dado novo que se encaixava no quebra-cabeças e contribuía para perceber melhor o quadro que se anunciava, mas se me deixasse levar pelo entusiasmo que advém das pequenas descobertas, estaria afastando-me do meu propósito que é muito mais o presente e iria fazer pesquisa de história.

Foi preciso então selecionar e não acumular demais, trazendo para esta dissertação apenas o necessário para mostrar que foram várias as iniciativas de produção de cinema/vídeo nas áreas do Ensino, da Pesquisa e da Extensão, desta Universidade. De fato, não me aprofundei, mas revolvi o solo o suficiente para conhecer da sua fertilidade, levantei dados, localizei casos significativos. Filmes antigos pouco encontrei, fiz algumas entrevistas, e tudo isso resultou num panorama que, além de corroborar minha visão sobre o tema em questão, espero, seja útil a outros pesquisadores.

Em 1996, como aluno de pós-graduação do CTR - Departamento de Cinema, Rádio e Televisão da ECA, fui convidado a participar, na condição de diretor, da produção de um vídeo institucional da USP. O propósito era apresentar a Universidade ao público externo que freqüentemente a visita e, também, oferecer aos seus 
professores, que participam de Congressos ou realizam viagens, um material que apresentasse uma síntese do que é e o que faz esta instituição. O então reitor Prof. Dr. Flávio Fava de Moraes encaminhou a solicitação dessa produção à CCS Coordenadoria de Comunicação Social. Com isso inaugura-se uma nova postura da USP diante da questão da produção de sua própria imagem - o programa de apresentação da Universidade de São Paulo deveria ser produzido por ela mesma e não, como em ocasiões anteriores, contratar uma empresa para fazê-lo. Também inédita foi a proposta de que o vídeo não deveria refletir apenas o momento da Universidade naquela gestão, mas sim refletir o espírito permanente da USP, enfatizando o significado mais amplo da instituição no mundo das ciências, cultura e na própria vida dos que fazem a Universidade, professores, alunos e funcionários.

$\mathrm{Na}$ imprensa escrita e na radiodifusão a Universidade já vinha trabalhando com autonomia em seus veículos próprios - a Rádio USP entrou em funcionamento em 1977 e o Jornal da USP abre suas páginas em 1985, mas em vídeo, o recurso audiovisual mais comum da atualidade, a Reitoria ainda dependia de serviços externos. Cabia, naquele momento, buscar na própria instituição as competências necessárias à realização de uma produção que fizesse juz ao nome que a assinaria. A CCS coordenou uma articulação que envolvia professores, alunos, funcionários e recursos técnicos de quatro unidades da universidade - a Cecae/UNIVÍDEO, a ECA, a FAU e o LSI da POLI. Não vou aqui detalhar essa experiência de co-produção, resgato esse episódio para contextualizar o início do levantamento histórico que realizei. Naquela ocasião houve uma ampla pesquisa para a elaboração do roteiro e dos materiais que passavam pelas minhas mãos saltavam algumas informações que estimularam a curiosidade. $\mathrm{O}$ que mais chamava a atenção era, primeiro, o próprio Decreto de Fundação da Universidade e, segundo, as informações de produção de filmes documentários, na década de 50, como consta no livro História da Universidade de São Paulo de 1954, do Prof. Dr. Ernesto de Souza Campos ${ }^{18}$. Resolvi começar por verificar, nos estatutos e regimentos editados no decorrer da história desta Universidade, o que existia relativo à utilização de recursos audiovisuais.

\footnotetext{
${ }^{18}$ Ernesto de Souza Campos, foi professor da Faculdade de Medicina da USP por mais de trinta anos. Participou das primeiras discussões sobre o ensino superior no Brasil e da criação da Universidade de São Paulo e era francamente favorável ao uso do rádio e do cinema pela universidade. Integrou a Comissão para o estudo da localização das instalações da Universidade sendo, depois, presidente da Comissão da Cidade Universitária.
} 


\section{1 - O audiovisual nos estatutos e regimentos da USP}

Assim reza o Decreto no. 6.238 de 25 de janeiro de 1934 quanto aos fins da universidade:

Art. $2^{\circ}$ - são fins da universidade:

a) promover, pela pesquisa, o progresso da ciência;

b) transmitir, pelo ensino, conhecimentos que enriqueçam ou desenvolvam o espírito ou sejam úteis à vida;

c) formar especialistas em todos os ramos de cultura, e técnicos e profissionais em todas as profissões de base científica ou artística;

d) realizar a obra social de vulgarização das ciências, das letras e das artes, por meio de cursos sintéticos, conferências, palestras, difusão pelo rádio, filmes científicos e congêneres. (grifo meu, o Anexo I apresenta cópia do decreto)

Ora, para a perspectiva colocada nesta dissertação é muito significativo encontrar já na gênese da Universidade de São Paulo, no documento que expressa os ideais universitários da época, a proposta de uso do rádio e do cinema dentre as atividades da instituição. Por mais um pouco de tempo e estaria incluída aí a televisão. Foi no ano seguinte, 1936, que o novo meio de comunicação entrou em operação comercial na Inglaterra! E caso já estivesse difundido o seu uso, como estavam o rádio e o cinema, com certeza os autores desse decreto ${ }^{19}$ teriam-na incluído dentre os recursos para a realização do papel social da nova universidade (essa proposta não tardou a surgir assim que a TV chegou ao Brasil) ${ }^{20}$.

\footnotetext{
${ }^{19}$ Uma comissão composta por Agesilau Bittencourt (Instituto Biológico), Almeida Júnior (Instituto de Educação), André Dreyfus (Faculdade de Medicina), Júlio de Mesquita Filho (O Estado de S. Paulo), Raul Briquet (Faculdade de Medicina), Rocha Lima (Instituto Biológico) e Vicente Rao (Faculdade de Direito) discutiu e elaborou o decreto de criação da Universidade, in: USP: Alma Mater Paulista. Maria Cecília Loschiavo dos Santos, São Paulo, EDUSP, 1998.

${ }^{20}$ Em sessão de 19/12/1952, o Conselho Universitário aprovou proposta dos Diários Associados, no sentido de serem realizados programas de difusão cultural, pela televisão, sob orientação da Universidade de São Paulo, sem qualquer pagamento, desde que a Reitoria concordasse que uma empresa particular
} 
Se o decreto de fundação da universidade menciona a utilização do rádio e do cinema, o faz por estarem seus autores integrados ao ambiente de renovação do ensino existente no Brasil da época:

“A década de 20 é o marco de uma grande reforma na educação brasileira. O desejo de criar as bases para o erguimento de um país moderno e progressista orientou a reflexão e as iniciativas de um número significativo de educadores, em vários estados. $\mathrm{O}$ pensamento da Educação Nova institucionalizou-se, em 1924, através da Associação Brasileira de Educação, reforçando os ideais do grupo que se disseminaram nas reformas estaduais conduzidas em São Paulo, Rio de Janeiro (Distrito Federal), Ceará, Bahia, Minas Gerais, com a criação das Diretorias Gerais de Ensino."21

As discussões em torno do sistema educacional do país estenderam-se por toda a década de 20, com a participação de educadores, intelectuais, jornalistas, da Associação Brasileira de Educação - ABE, do Rio de Janeiro e do jornal O Estado de São Paulo, incluindo-se nos debates a questão da universidade no Brasil. Buscava-se definir o papel e o perfil que o sistema universitário brasileiro deveria assumir, o tipo de universidade, a dedicação do professor, a abrangência dos cursos, as particularidades regionais, os recursos materiais necessários.

"Houve, sem dúvida, naquela época, um movimento amplo em que uns proclamavam as virtudes e exigências da vida universitária e outros, aqui em São Paulo, além de substanciosa e proveitosa elucidação do problema, ainda pelejavam pela criação de uma universidade em nossa Metrópole."22

Junto a essa movimentação ocorria uma outra discussão, iniciada na década anterior na Europa, e que trazia o cinema à pauta da agenda educacional: " $O s$ educadores, porém, logo perceberam a vocação educativa da linguagem cinematográfica e começaram a organizar, em todo o mundo, entidades a pesquisar $e$

patrocinasse os programas, sem qualquer propaganda, in História da Universidade de São Paulo, Ernesto de Souza Campos, São Paulo, USP, 1954. Consta que foi designada uma comissão para estudar o assunto, porém o processo relativo, de número $18758 / 52$, não foi localizado nos arquivos da Reitoria para verificarmos o desenrolar do caso.

${ }^{21}$ Franco, Marília da Silva. Escola audiovisual. Tese de Doutorado, São Paulo, ECA/USP, 1987.

22 Campos, Ernesto de Souza. História da Universidade de São Paulo, São Paulo, USP, 1954. 
elaborar estudos e projetos que estimulassem e desenvolvessem essa possibilidade entrevista." 23

O uso educativo das imagens em movimento difunde-se rapidamente "por volta de 1910, catálogos especializados de filmes educativos eram disponíveis nos EUA, na França e na Inglaterra”"24 e “... o Brasil pode ser considerado um dos países precursores, senão no emprego ordenado, pelo menos na preocupação de utilização do cinema educativo." 25

O jornal "O Estado de São Paulo" promoveu, em 1926, um inquérito, sob a direção do Dr. Fernando de Azevedo, sobre os problemas e necessidades do sistema educacional no Brasil, e ali perguntava: "Não acha que o Estado de São Paulo não poderá resolver, de maneira intensiva e extensiva, o problema da educação popular, sem pôr a serviço dessa obra os grandes recursos modernos como o cinema e a radiotelefonia?" 26 As respostas foram unânimes opiniões favoráveis.

Em julho de 1931, a Diretoria Geral de Ensino de São Paulo instituiu uma Comissão para organizar a atividade cinematográfica no âmbito da educação e houve uma "Semana do Cinema Educativo", para divulgar e demonstrar os recursos que o cinema oferecia ao ensino. Essa movimentação em torno da questão cinema/educação tem a sua mais expressiva e concreta realização com a criação do INCE - Instituto Nacional de Cinema Educativo em 1937. Idealizado por Roquete Pinto em 1935, tal iniciativa obteve o apoio do Ministro da Educação Gustavo Capanema e foi inserido na nova organização do Ministério da Educação e Saúde Pública, conforme a Lei no. 378, que, em seu artigo no. 40, destinava o INCE a promover e orientar a utilização da cinematografia, especialmente como processo auxiliar do ensino e ainda como meio de educação em geral. ${ }^{27}$

\footnotetext{
${ }^{23}$ Franco, Marília da Silva Ibid.

${ }^{24}$ Pfromm Netto, Ibid.

${ }^{25}$ Parra, Nélio. Ibid.

${ }^{26}$ Franco, Marília da Silva Ibid.

${ }^{27}$ Franco, Marília da Silva Ibid.
} 
A nova universidade nascia sob o foco das luzes da modernização econômica, social e cultural do país, acesas desde os anos 20. Nesse contexto nada mais natural que no ato de criação da tão almejada Universidade de São Paulo já se mencionasse explicitamente o uso do rádio e de filmes científicos para a vulgarização do conhecimento.

Verificando o decreto de criação da USP encontramos mais adiante, em seu capítulo VI, sobre os laboratórios e demais instalações universitárias, que a Universidade terá salões de conferências apropriadas para projeções cinematográficas, uma filmoteca e uma discoteca e um estúdio para transmissão pelo rádio. Temos assim, na origem desta Universidade, a proposta de utilização de recursos audiovisuais para cumprir uma das finalidades da instituição e a disposição de infra-estrutura para concretização de tal objetivo.

Esse decreto, em seus 54 artigos, não detalha toda a estrutura da nova instituição, tal matéria seria elaborada no decorrer dos primeiros anos de vida universitária. Em 29 de fevereiro de 1944 o decreto $\mathrm{n}^{\mathrm{o}} 13.855$ regulamenta a organização da universidade. A Reitoria compreendia então, entre outros, o DCAS Departamento de Cultura e Ação Social e neste encontramos a Divisão de Rádio e o Serviço de Documentação com sua Seção de Cinema Educativo à qual competia, inclusive, a produção de documentários. Tal Seção de fato existiu e pretendo relatar um pouco de sua história e do DCAS mais à frente. No momento quero apenas concluir com as informações de interesse que constam das edições seguintes dos estatutos e regimentos da USP.

Em $1^{\circ}$ de Setembro de 1964, a Reitoria da USP publica a portaria no 00 , que é a consolidação dos estatutos da universidade editados até então. Ali já não encontramos a indicação do uso do rádio e do cinema como meios para alcançar a finalidade de vulgarização das ciências.

Os fins da universidade estão resumidos a dois itens:

Art. $1^{\circ}$ - a Universidade de São Paulo, criada pelo decreto estadual no 6.283 , de 25 de Janeiro de 1934, tem por finalidades: 
I - promover, incentivar e divulgar a cultura e a pesquisa;

II - formar pessoas habilitadas para a investigação filosófica, científica, artística e literária, e ao exercício das profissões liberais, técnico-científicas, técnico-artísticas e de magistério.

Já a estrutura da Reitoria descrita nesses estatutos preservou algo do passado. No capitulo II, artigo 17, consta o Departamento de Serviços Técnicos e que este compreendia ainda o Serviço de Documentação, o mesmo que pertencia ao Departamento de Cultura e Ação Social na década de 50.

Novos estatutos são editados através do decreto no 52.326, de 16 de Dezembro de 1969. Aqui surge pela primeira vez, com essa denominação, a Escola de Comunicações e Artes criada em Junho de 1966, com o nome de Escola de Comunicações Culturais e, também, o órgão antecessor da atual CCS - Coordenadoria de Comunicação Social , a CODAC - Coordenadoria de Atividades Culturais.

O decreto $\mathrm{n}^{\mathrm{o}}$ 52.906, de 27 de Março de 1972, aprova o Regimento Geral da Universidade, detalhando sua estrutura e dele consta, como parte integrante da Reitoria, a CODAC, que tinha por finalidade promover atividades de caráter cultural, destinadas à divulgação dos conhecimentos e progressos verificados nas ciências, letras, artes e na técnica (Art. 44, grifo meu) e a TV Educativa.

Conforme o Artigo 48 - A TV Educativa tem por objetivo ampliar a capacidade docente da USP e propiciar o estudo das inter-relações entre o desenvolvimento da criatividade e a utilização das novas tecnologias educacionais.

Já não há menção ao Serviço de Documentação nem à Seção de Cinema Educativo, nos processos que consultei, da Secretaria Geral da Reitoria, nada localizei sobre a extinção desse serviço nem do destino de seu patrimônio.

O estatuto hoje em vigor é a resolução nº 3461, de 07 de Outubro de 1988 e suas complementações até Setembro de 1999. Esse documento não apresenta nenhum dos serviços apontados anteriormente e nem mesmo é citada a CCS - Coordenadoria de Comunicação Social. 
Na edição atualizada, de 1998, do Regimento Geral há apenas a indicação de que a CCS está vinculada à Reitoria (Art. 253) porém sem detalhamento de sua estrutura ou finalidade. A TV Educativa que constava do regimento de 72, desaparece. Por mais que procurasse nesses documentos recentes, não localizei nada que envolvesse recursos audiovisuais, televisão, educação a distância, difusão cultural ou divulgação científica. Tais assuntos não estão mais no âmbito da macroestrutura da universidade, foram deslocados para o segundo plano, aquele das atribuições próprias de outros setores da universidade.

Se depender dos estatutos parece que a USP, na contramão da história, ao invés de incrementar a presença do audiovisual em sua estrutura, foi retirando-lhe o espaço inicialmente concedido. Isso que verificamos nos vários regimentos e estatutos da universidade apenas esconde o que, de fato, ocorreu nos meandros dessa instituição, em diversas ocasiões, em diversas escolas, em relação à produção de filmes e de vídeos. Não que tais iniciativas tenham acontecido sem a participação e o apoio dos órgãos centrais da USP, muito pelo contrário a experiência que relatarei em seguida, do Serviço de Documentação do DCAS, estava inserida na própria Reitoria, mas os estatutos que regem esta universidade foram, paulatinamente, "esquecendo" a importância da comunicação audiovisual para o desenvolvimento das suas atividades próprias, de ensino e de pesquisa, e como meio de integrar-se à sociedade.

"Deveria a universidade, como maior centro gerador de ciência e tecnologia, estudar uma estratégia e procurar abrir espaço para divulgar suas realizações também por esses meios. Se avaliarmos que, muitas vezes, o rádio e a televisão ocupam quase que programas inteiros com ocorrências de caráter policial e pouco se dedicam a fatos que podem contribuir para melhorar as condições de vida do cidadão, não socializando as novas descobertas no campo científico e tecnológico, algo deve estar deslocado numa genuína escala de valores. Urge assumir algumas ações concretas para mudar esse quadro.”. ${ }^{28}$

\footnotetext{
${ }^{28}$ Kunsh,, Margarida M. Krohling. Universidade e Comunicação na Edificação da Sociedade, São Paulo, Ed. Loyola, 1992.
} 


\section{2 - O Serviço de Documentação do DCAS - Departamento de Cultura e} Ação Social

As informações sobre o Serviço de Documentação foram inicialmente levantadas no trabalho comemorativo ao IV Centenário da cidade de São Paulo, do Prof. Dr. Ernesto de Souza Campos que elaborou, detalhadamente, o relato dos primeiros 20 anos da história da Universidade. ${ }^{29}$ Souza Campos, um entusiasta do cinema e do rádio educativos, em artigo publicado em 1952 relata:

“Certa vez fiquei embaraçado em ilustrar um curso realizado no Rio de Janeiro. Por intermédio do professor Gudin tomei conhecimento da existência do Cinema Educativo, organização a que, depois, procurei dar o maior prestígio.

Desde aquela época introduzi definitivamente o cinema educativo no curso que dirijo em nossa Faculdade de Medicina. Empenhei-me, também, para que a nossa Universidade criasse serviço idêntico ao do Rio. O apêlo foi ouvido. Com o auxílio dos Fundos Universitários de Pesquisa, o cinema educativo associou-se ao serviço já instituído do microfilme universitário." ${ }^{30}$

Este serviço tem sua origem no Serviço de Divulgação Bibliográfica, criado em 1944, para facilitar o acesso a artigos de periódicos na área de Biologia e funcionou inicialmente na Faculdade de Medicina. Com o apoio da Fundação Rockfeller recebeu uma das primeiras máquinas de microfilmagem no Brasil para o armazenamento e difusão de informações científicas, atendendo a pesquisadores da universidade e de outros centros de pesquisa do país e do exterior. Em 1948 foi incorporado ao DCAS Departamento de Cultura e Ação Social. Segundo o relato de Souza Campos, o serviço foi reorganizado em 1950 e passou a desenvolver outras atividades, agora com a denominação de Serviço de Documentação:

"Nessa época, foi o Serviço de Documentação instalado à rua Vieira de Carvalho,

$172,5^{\circ}$ andar, com equipamentos inteiramente novos e modernos.

\footnotetext{
${ }^{29}$ História da Universidade de São Paulo, São Paulo, USP, 1954.

${ }^{30}$ Souza, Ernesto de Souza. Temas Universitários, São Paulo, USP, 1952.
} 
Com a reforma, introduziram-se novas produções de materiais correlatos aos trabalhos fotográficos, tendo-se em vista o melhor aproveitamento da capacidade dos aparelhos foto-técnicos adquiridos.

O Serviço de Documentação opera, atualmente, com 25 funcionários especializados e compreende:

- Secção de Cinema Educativo

- Biblioteca Central

- Seção de Microfilme

À Secção de Cinema Educativo compete:

- organizar filmes documentários sobre as atividades da Universidade de São Paulo;

- confeccionar filmes de caráter educativo;

- proceder a ampla divulgação dos mesmos, em colaboração com a Divisão de Difusão Cultural;

- cooperar com outras entidades de caráter cultural, mantendo e incentivando o intercâmbio de filmes.

O Serviço já exibiu 260 filmes de 35 e 16 m/m, de conteúdo educativo e científico na capital e outros Estados do Brasil. Realizaram-se empréstimos de mais de uma centena de filmes e filmagens de mais de 1.500 metros, compreendendo cenas da Cidade Universitária e aspectos tradicionais de Ouro Prêto, Congonha dos Campos, Itanhaen, etc." 31

Não foi sem surpresa que li tal relato. A USP, nos anos 50, produzindo filmes já com recursos próprios! Quem? Como? E, principalmente, por que tal experiência de trabalho praticamente desapareceu da memória da Universidade? Para onde foram os filmes realizados? A partir das informações colocadas por Souza Campos busquei mais dados até mesmo para verificar se isso tudo era verídico ou apenas propostas não realizadas, frutos de um devaneio idealista. Em consultas ao arquivo da Secretaria Geral da Reitoria localizei o processo 10839/55 que trata da reestruturação dos órgãos remanescentes do DCAS - Departamento de Cultura e Ação Social, extinto em Outubro de 1955.

\footnotetext{
${ }^{31}$ Souza, Ernesto de Souza. História da Universidade de São Paulo, São Paulo, USP 1954.
} 
O DCAS havia sido criado em 1944, mas só instalado em 1948. Tinha por finalidade promover ampla difusão cultural e, ao mesmo tempo prestar completa assistência aos estudantes universitários e compreendia três Divisões - Difusão Cultural, Ação Social e Imprensa e Rádio. À Divisão de Imprensa e Rádio cabia:

“... distribuir notícias de interesse da universidade aos jornais e às emissoras de rádio, realizar gravações sonoras, manter um estúdio experimental, organizar representações radiofônicas de caráter educativo, proceder à confecção e divulgação de filmes educativos ou documentários das atividades da universidade." ${ }^{32}$ (grifo meu).

Não localizei informações sobre as razões da extinção do DCAS, o processo 10839/55 trata apenas do destino a ser dado aos serviços do Departamento e arrastou-se até 1960.

A reorganização do DCAS extinguiu a Divisão de Rádio, transferindo parte de seu patrimônio - microfones, amplificadores, osciloscópios, para o Instituto de Eletrotécnica da Escola Politécnica ${ }^{33}$. Suas atribuições foram divididas entre as áreas de difusão cultural e de documentação que, inicialmente, seriam inseridas na recém criada Comissão de Pesquisa e Extensão Universitária. Em 1960 é proposta uma nova organização aos serviços de difusão, documentação e de referências bibliográficas, desta vez como divisões vinculadas à Secretaria Geral da Reitoria ${ }^{34}$. Nesse momento consta como competência da Divisão de Documentação Técnico Científica "documentar, por todos os processos audiovisuais, as atividades da Universidade de São Paulo; manter intercâmbio bibliográfico e de microfilmes; proceder à elaboração de filmes e diapositivos de caráter educativo; e formar e aperfeiçoar servidores em fotodocumentação" (pag 113, grifo meu). Porém tal formalização não ocorreu e os estatutos de 64 colocaram a documentação como um serviço do Departamento de Serviços Técnicos da Reitoria.

A questão não é meramente burocrática. A morosidade no processo em definir onde e como inserir as atividades de difusão cultural e de produção de materiais audiovisuais para o ensino e a extensão apontam para o pouco interesse da Universidade

\footnotetext{
${ }^{32}$ Washington, Luis. Universidade de São Paulo, monografia, São Paulo, USP, 1950.

${ }^{33}$ Pág. 25 do processo RUSP 10389/55.

${ }^{34}$ Pág. 112 do processo RUSP 10389/55.
} 
de São Paulo em posicionar-se diante de tais questões. Sempre vinculadas à Reitoria tais atividades passaram por diversas formas de organização e por trás das formalidades ocorriam discussões sobre o grau de autonomia que tais atividades deveriam ter.

Em junho de 55, o então Reitor Prof. Dr. Alípio Corrêa Netto questionava o art. 35 do Regimento Interno da USP que atribuía à Divisão de Difusão Cultural a competência de promover e incentivar, por todos os meios à sua disposição, atividades de caráter cultural destinados à divulgação dos conhecimentos e progressos verificados no setor das Artes, das Ciências e das Letras, afirmando que a Divisão de Difusão Cultural "é, por assim dizer, uma universidade dentro de uma universidade" e que esta "viria a superpor-se aos Institutos universitários" 35 . Em seguida o Reitor propõe reduzir tal órgão à condição de serviço de coordenação das medidas necessárias à divulgação cultural promovida pelos órgãos de ensino e pesquisa integrantes da Universidade de São Paulo. Mais adiante propõe extinguir a Divisão de Rádio reorganizando suas atribuições, como já citado acima. Um outro parecer comenta que:

“de fato, quando se estabelece que a Divisão entrará em entendimentos com as Faculdade e Institutos da Universidade de São Paulo para promover a difusão, o que se deve entender é que a iniciativa é da Divisão. Em vez de ser ela um orgão central auxiliar à disposição dos Institutos da Universidade, ela inverte a relação e passa a pedir ou a esperar que estes Institutos lhe tragam a sua contribuição. Mais ainda, se esses institutos se furtarem à colaboração, a Divisão poderá dar desenvolvimento ao seu magnífico programa de difusão cultural apelando ou comprando a colaboração de universidades nacionais e estrangeiras, ou mesmo das entidades culturais em geral. Na universidade, cujo objetivo é a difusão cultural, um departamento especializado nessa função dá a entender que os demais órgãos, ou sejam os institutos universitários, não preenchem a contento essa função, ou então que não a devem preencher senão com o concurso daquele departamento, o qual, controlando parte dos recursos de que os institutos carecem, colocaria, na prática, os institutos em posição de subordinação" 36

Ainda no processo de reorganização dos serviços do DCAS consta que, em reunião de 08 de agosto de 1960, o Conselho Universitário decidiu que "compete à Divisão de Difusão Cultural promover e incentivar, mediante autorização superior,

\footnotetext{
${ }^{35}$ Pág. 2 e 3 do processo 10389/55.

${ }^{36}$ Processo Rusp 10.839/55, pag. 11 e 12.
} 
cursos, conferências, publicações e quaisquer outras atividades de caráter cultural destinadas à divulgação dos conhecimentos... etc. "(grifo meu).

A questão de autonomia ou não, porém sob outro viés, atingiu também o Serviço de Documentação. Chefiado, desde sua origem em 1950, pelo Sr. Guelfo Oscar Campiglia, este abre processo, em 1963, junto à Reitoria pleiteando a mudança da designação de Serviço para Divisão, argumentando que:

“sem embargo de ser um órgão 'meio’ na prestação de serviços especialíssimos aos usuários da documentação especialmente, científica e tecnológica, verifica-se que esses serviços fundam-se em um complexo de 'teorias e técnicas' cujas aplicações, dos mais simples aos mais complicados 'procedimentos tecnológicos', exigem um corpo de técnicos, dentre os quais documentalistas, bibliotecários, cineastas, etc,(...) Cabe dizer ainda, que é fator essencial aos organismos especializados o fornecimento rápido, atualizado e completo, face o ritmo acelerado dos acontecimentos científicos e técnicos na atualidade de onde se infere que, os organismos documentários devem gozar de autonomia suficiente para que a burocracia não represente fator negativo e colidente com a própria natureza do 'serviço' a prestar, ... A atividade informativa é realmente um importante 'serviço', nunca um ‘Serviço' no sentido ‘Estatutário.” 37

Os casos citados colocam, no meu entender, duas questões da maior relevância para a relação Comunicação X Universidade:

1- qual é o tipo de relacionamento que deve se estabelecer entre os especialistas em comunicação e os pesquisadores das ciências? A iniciativa de produção de materiais de divulgação é exclusiva de um deles ou cabe a ambos a sua proposição?

2- qual é a organização, dentro da estrutura burocrática da universidade, mais eficiente para um serviço de produção audiovisual? Qual deve ser o seu grau de autonomia, frente às especificidades do serviço, para superar as limitações impostas pelas regulamentações de prestações de contas, de previsões de custos, dos necessários serviços de terceiros, conforme comentei na apresentação desta dissertação.

\footnotetext{
${ }^{37}$ Processo Rusp 15.625/63
} 
Convém destacar que os estatutos editados em 1964 simplesmente suprimiram a difusão cultural da estrutura da Reitoria restando apenas o Serviço de Documentação, vinculado ao Departamento de Serviços Técnicos. Havia, sim, o Departamento de Extensão Universitária para cuidar de Relações Universitárias, Museus, Orquestra e Teatro Universitários.

Sobre as atividades do Serviço de Documentação consta ainda, segundo o relato de Souza Campos, que

“... destaca-se a produção de diapositivos ..., no exercício de 1952, foi de 18.000 unidades, na maioria entregues às diversas cátedras universitárias, (...) além dos citados, funcionam outros serviços extraordinários, tais como: formação e aperfeiçoamento de 'técnicos de documentação'... As instalações de laboratórios de revelação, cópias, sonorização etc., estão projetadas e serão concluídas, sob especificações técnicas, no Edifício da Reitoria, em construção na Cidade Universitária". ${ }^{38}$

Com tantas atividades descritas era necessário buscar confirmações e tentar resgatar essa experiência de produção. O Serviço de Documentação, desde seu inicio, em 1950, até sua extinção, no final dos anos 60, foi chefiado pelo Sr. Guelfo Oscar Campiglia. Procurei então pessoas relacionadas à questão e fui encontrar Oscar Campiglia, filho do Sr. Guelfo (falecido em 1969), morando em Campinas. Lá pudemos resgatar um pouco da história desse que foi um pioneiro na produção audiovisual na USP. Segundo o relato de Oscar Campiglia, ${ }^{39}$

“A primeira instalação física do Serviço de Documentação foi feita lá na rua Vieira de Carvalho 172, $5^{\circ}$ andar, próximo do largo do Arouche, um pouquinho próximo também da praça da República, em São Paulo.

Então o Serviço de Documentação ocupava todo o $5^{\circ}$ andar e tinha do lado esquerdo as câmaras escuras, o laboratório fotográfico, a secagem, e foi inclusive numa das salas que foi instalada uma das primeiras grandes máquinas de microfilmagem no Brasil, já que o objetivo do serviço de documentação na primeira fase da sua instalação era fazer reprodução de bibliografias, livros, revistas, etc, para atendimento de pesquisadores da USP. E na continuação, no centro havia a parte

\footnotetext{
${ }^{38}$ Souza, Ernesto de Souza. Ibid

${ }^{39}$ Depoimento coletado pelo autor em novembro de 1999
} 
organizacional, de busca e recuperação das obras a serem reproduzidas, e do lado direito havia uma seção de cinema onde havia uma pequena sala de projeção com projetor 16 e $35 \mathrm{~mm}$ e os aparelhos de som e um pequeno estúdio de gravação de som.

E ali foram produzidos e expostos e testados as primeiras produções de cinema que eu tenho conhecimento, que foram feitas pela USP de uma forma mais específica como documentação e divulgação de informação, ... assisti, assistimos às primeiras exibições de alguns dos documentários que ele fez como o alcoolismo, o tratamento de madeiras, e eu me lembro também ,e isso ficou muito gravado prá mim, ele tinha feito um estudo sobre iluminação durante uma missa. Então ele fez uma iluminação toda especial, do levantamento do cálice, da hóstia, as luzes batendo naqueles dourados todos, fazia aqueles halos, ...ficou muito bonito. As primeiras produções ele fez em 16 mm. Como se chamavam aquelas câmeras antigas? Paiard ?Faiard?

Tinha um rapaz, é muito interessante e curioso, porque ele cuidava da parte de som. Ele fazia sonoplastia e ele era sonoplasta da rádio São Paulo, naquela época, então ás vezes eu ia visitá-lo lá na rádio que era ali na avenida Angélica. Além dele parece que tinha mais duas pessoas trabalhando lá, e quando ele estava produzindo os documentários ele contratava de fora, pegava profissionais de outros lugares. Deve ter evidentemente feito conhecimento com muita gente da indústria do cinema da época. Eu me lembro que em termos de equipamento havia ali na rua Santa Ifigênia e arredores, era o centro das industrinhas de máquinas fotográficas, consertos, fazia cinema, alugava-se máquina, e uma porção de coisas desse gênero e ás vezes eu ia lá pegar alguma máquina ou levar alguma coisa prá arrumar. Mas na verdade eram poucas pessoas que estavam diretamente ligadas ao setor.

Isso mostra que havia uma certa facilidade em termos orçamentários mas também não havia muita facilidade em termos de pessoal. Isso sempre foi um problema, conseguir gente especializada, e de bom nível para atuar nessa área.

Ele fazia tudo! Ele chegava até a exagerar na centralização, porque claro que um trabalho desse tipo se for de porte maior ele exige a participação de cada especialista na sua área. Mas como não havia, ele começava desde o roteiro, fazia todo o planejamento, a produção, a locação de equipamentos, fotografia, revelação, edição. Eu acompanhava até certo ponto, porque eu estava estudando na época, não tinha muita possibilidade de um acompanhamento permanente.

Depois o setor mudou para o prédio da Reitoria velha, lá na Cidade Universitária, então ele ocupou inicialmente a ala direita do prédio da Reitoria, com a 
seção de foto-documentação e reprodução bibliográfica, com a seção de cinema, com o laboratório e o embriãozinho de uma gráfica. Mas depois com a outra ala do prédio, aí pôde se expandir mais a gráfica e algum laboratório. E lá ficou até a criação da Escola de Comunicação e Artes, cuja comissão de criação foi integrada por ele e depois deve ter se juntado à escola.

Como ele era pintor antigamente e gostava muito do barroco, ele começou a pesquisar o barroco brasileiro em termos de documentação religiosa, igreja, etc. A partir daí ele começou a fotografar essas igrejas. E fotografou as igrejas paulistas, depois as mineiras, depois as baianas, e aí ele foi estendendo, pegando as pernambucanas, as paraibanas e também do Sul. E isso gerou um acervo bem grande de fotos. Existem coleções de fotografias muito grandes derivadas desse trabalho.

Uma parte deste material que estava em casa, eu fiz uma doação para a Unicamp para garantir que esse acervo fosse realmente mantido e servido para várias pesquisas. $O$ restante do material também como aquelas produções antigas de filmes, etc, ficaram na USP, só que a gente não tem ciência exatamente de onde eles estão.

$O$ trabalho dele tinha todo um roteiro preparado com levantamentos. Naturalmente prá fazer isso ele teve que pesquisar em muitos livros, visitou muitos locais antes de mais nada, fez isso antes de fotografar, ... inclusive ele fazia um estudo completo das igrejas, no caso do barroco. Ele desenhava, ele era pintor, então ele desenhava todo o frontispício, destacava os elementos chave do barroco, os elementos de ligação, a idade, e a partir daí ele fazia um estudo de todo o interior da igreja, como é que ela era, como ela tinha sido construída. Enfim, tudo isso foi devidamente organizado prá que se realmente tivesse um instrumento documentário de bom nível. E eu me lembro, isso eu achei interessantíssimo, o cuidado nas fotografias, foi muito grande. Então ele usava aquelas máquinas, mais modernas que ele podia contar na época, e todas com dispositivo de correção, aqueles foles que você podia acertar os ângulos e destacar os elementos principais. Aí a gente tinha uma bateria de flashes eletrônicos e a gente fazia estudos de ângulo, ficava um aqui, outro aqui, outro lá, às vezes 4 flashes prá iluminar e destacar os elementos mais importantes de cada composição. Às vezes tinha que tirar 10, 15, 20 chapas de uma única peça prá poder realmente realçar aquilo que era mais significativo.

O trabalho que o meu pai desenvolveu, eu vejo a coisa do ponto de vista pessoal dele, um idealismo muito grande. Ele era de um desprendimento absurdo em termos de fazer o bem, de ensinar, de transmitir conhecimento, de fazer coisas úteis. Isso serviu 
como um elemento que alavancou uma iniciativa e uma atividade, mas é como uma planta que se joga num terreno fértil, se você joga uma boa semente numa coisa árida não sai nada. Então, de repente essa iniciativa e essa criatividade, esse espírito artístico e idealista, uma força de trabalho que isso gerava, muito grande, caiu num terreno que precisava daquela semente, que naquela época, a USP estava crescendo, precisava de meios de divulgação, de meios de reprodução de informação científica e cresceu, se desenvolveu de uma forma muito grande, muito bonita, e gerou toda essa série de eventos que a gente está vendo hoje que foram muito proveitosos na época.

Então na verdade é isso, é um espírito empreendedor dentro de uma realidade necessitada daquele trabalho."

Encerrada a entrevista fiquei ainda mais instigado a localizar os filmes de G. O. Campiglia. Seu filho cedeu-me uma cópia do currículo do pai, onde estava citado, no item Cinematografia, que: "Produziu cerca de 10 documentários cinematográficos destacando-se dentre eles: "Modernos Sistemas da Construção"; "Apêlo”, filme sobre ecologia, baseado na tese do Prof. Dr. Mário Guimarães Ferri; "Cidade Universitária”; "Alcoolismo", etc”

Chama a atenção, nesse curriculum vitae, a diversidade de atividades que o Sr. Campiglia desenvolveu na área de documentação, não só em cinema, fotografia, microfilmagem, microfotografia científica, mas também na organização de vários Centros de Documentação, no país e no exterior. Ocorreu, ao ler tais páginas, um desses cruzamentos de informações que, muitas vezes, indicam algumas constantes de um processo em observação. O Sr. Guelfo Campiglia elaborou um projeto de reorganização do Instituto Brasileiro de Bibliografia e Documentação - IBBD, do CNPq (o currículo é de 1968). No final dos anos 80 o Prof. Nelson Pretto, da UFBa, desenvolveu, numa articulação entre FUNTEVÊ, CNPq e IBICT- Instituto Brasileiro de Informação em Ciência e Tecnologia -, o Projeto Universidade Vídeo que veio a ser, em 1993, o embrião do projeto UNIVÍDEO, na USP. O que se destaca é que algumas práticas propostas no Serviço de Documentação, dos anos 50, são também referendadas nos anos 90: a formação de técnicos em produção audiovisual, o intercâmbio de filmes/vídeos, o apoio ao uso da imagem nas atividades de ensino, pesquisa e extensão da universidade. 
Dos filmes mencionados no currículo localizei dois no acervo da Fundação Cinemateca Brasileira: “Apelo", uma cópia em $35 \mathrm{~mm}$, consta como produção do Serviço de Documentação da Reitoria da USP e "Modernos Sistemas de Construção", cópia de negativo, sem mais dados por não ter sido processado, está catalogado como material de preservação e é de acesso restrito, também produzido pelo Serviço de Documentação. A ficha técnica de "Apelo" indica o ano de 1961, direção de Trigueirinho Neto, baseado na tese de Mário Guimarães Ferri e produção de Oscar Campiglia.

Caberá a outras instâncias da USP, no caso de interessar o resgate de sua memória, providenciar a busca desses materiais.(o Anexo II apresenta documentos relativos à reorganização do DCAS)

\section{3 - Clube de Cinema na Faculdade de Filosofia, Ciências e Letras}

O cinema na USP tem uma passagem digna de nota, no início dos anos 40, não de forma oficial, mas como atividade paralela, através do Clube de Cinema da Faculdade de Filosofia, Ciências e Letras. Em torno de Paulo Emílio Salles Gomes e seus colegas da revista "Clima" (Antônio Cândido, Lourival Gomes Machado e Décio de Almeida Prado) as sessões de filmes selecionados, reunindo professores, alunos da Faculdade de Filosofia e outros intelectuais, criaram um ambiente de debates estimulando a formação de uma crítica cinematográfica. Tal experiência teve curta duração, pois logo chamou a atenção do DIP - Departamento de Imprensa e Propaganda, sendo fechado pelo governo Getúlio Vargas. Ainda ocorreram algumas sessões clandestinas na casa de Paulo Emílio, mas por pouco tempo. ${ }^{40}$

"Historicamente, as preocupações críticas com o cinema na USP remontam os anos 40, o Clube de Cinema da Faculdade de Filosofia, Ciências e Letras, tendo como figura central Paulo Emílio Salles Gomes. Só mais tarde constituiu-se formalmente uma área acadêmica neste setor e mais uma vez a presença deste intelectual foi decisiva para a implantação dos estudos de cinema no Brasil. Sobretudo, foi ele quem implantou uma

\footnotetext{
${ }^{40}$ Relato do professor Rudá de Andrade ao autor, em 11/02/2000.
} 
mentalidade preocupada em pensar o cinema dentro das questões cruciais da cultura de nosso tempo." 41

\section{4 - O Departamento de Produção de Filmes Documentários do IEB -} Instituto de Estudos Brasileiros.

Uma outra atividade em torno do cinema ocorreu no IEB, em meados dos anos 60, por iniciativa do Prof. Paulo Emílio Salles Gomes. Foi proposta e aprovada a criação de um Departamento de Produção de Filmes Documentários, ligado ao setor Cultural do Instituto. Suas atribuições e finalidades eram:

1 - a realização de documentários que atendessem aos interesses do IEB;

2 - a realização de estudos e debates sobre o cinema documentário;

3 - a programação e exibição de filmes de interesse das atividades do IEB;

4 - o estabelecimento de convênios com instituições nacionais ou internacionais para fomentar o intercâmbio cultural na área do cinema documentário;

5 - a formação de um centro de produção de documentários, com equipe e equipamentos próprios, a partir da obtenção de verbas, mediante convênios com entidades nacionais e internacionais.

O escopo da proposta é exemplar na sua inserção como difusão cultural dentro da instituição universitária. A mobilização que acarreta, pelas pesquisas necessárias à produção de documentários, pesquisas estas desenvolvidas e apoiadas pelo IEB, e nos estudos da linguagem cinematográfica, estimulados pelos debates, colocam a realização cinematográfica como elemento de integração intra e extra universidade. Um exemplo significativo dessa proposta, foi a palestra de Joris Ivens, importante documentarista holandês, ocorrida em 1967.

As produções, com o patrocínio do IEB e de instituições como Fundação Cinemateca Brasileira, FAPESP, Fundação Brasil Central e outras, contaram com a

\footnotetext{
${ }^{41}$ Santos, Maria Cecília Loschiavo dos. USP: Alma Mater Paulista, São Paulo, EDUSP, 1998.
} 
participação dos cineastas Francisco Ramalho Jr., Thomas Farkas, Sérgio Muniz, Paulo Gil Soares, Geraldo Sarno e enfocavam temas vários da realidade brasileira. Como exemplo cito o projeto "Pesquisa e documentários sobre cultura popular do Nordeste", realizado por Geraldo Sarno e Thomas Farkas e que resultou em 3 filmes: “Mestre Vitalino", 11 min., 1967; "Vitalino Lampião", 11 min., 1969 e "Jornal do Sertão", 11 min., 1970. O acervo de filmes consta de 15 documentários sendo 11 com produção ou co-produção do IEB. Apenas dois filmes têm cópias em fita de vídeo o que dificulta o acesso pois, projetores e técnicos em projeção são coisas raras hoje em dia. Vale citar também a produção de um documentário com o Prof. Paulo Emílio Salles Gomes entrevistando o poeta italiano Guiseppe Ungaretti, de 1968, porém este material foi extraviado.

Em depoimento coletado pelo autor, Sérgio Muniz, um dos cineastas participantes, relata uma parte desta história: ${ }^{42}$

“..., deve ser mais ou menos isso, final de 1965,... a partir de 4 produções que o Thomas Farkas tinha feito que é o "Nossa Escola de Samba", "Subterrâneo do Futebol", "Memórias do Cangaço" e "Viramundo", esses filmes tiveram uma certa repercussão nacional e de uma certa forma interessou muito Paulo Emílio e Maria Isaura Pereira de Queiroz. Então começaram a ver se haveria outras formas de continuar fazendo esse tipo de trabalho, não é um documentário sociológico, mas um documentário que tentasse ver a realidade brasileira ...,

..., então mexe daqui, mexe de lá, com relações do Paulo Emílio e da Maria Isaura se conversou com o Prof. José Aderaldo Castelo, que na época era o diretor geral lá do Instituto de Estudos Brasileiros, que aceitou uma proposta desse Departamento de Produção de Filmes Documentários, que na verdade era um nome pelo qual a gente pudesse estabelecer relações, não tinha cargo, não tinha função, não tinha dinheiro, não tinha nada ...,

..., as propostas partiram de nós, vendo o que era possível, no momento, fazer. Não era nenhum projeto. Eram coisas de fora para dentro.

..., então se propôs alguns trabalhos conjuntos com o IEB que resultaram em alguns trabalhos concretos, fosse uma produção totalmente de fora do IEB e que eles entravam com alguma coisa, fosse alguma coisa produzida mais quase que 
inteiramente com certos recursos do IEB, então eu diria que nessas duas possibilidades de produção houve a seguinte participação: no caso dos filmes que foram feitos prá fora, que foram feitos com Geraldo Sarno e Thomas Farkas, foi feito "Jornal do Sertão" e se não me engano “Vitalino Lampião”. São documentários do Geraldo Sarno que geram um trabalho de pesquisa que vai avançar, um ou dois anos depois, na continuação que o Farkas fez no nordeste inteiro, que acabou se transformando em "Brasil Verdade",43, onde nós fizemos uns 19 ou 20 documentários, do ano de 64 até quase 80. ( esse material foi recuperado por T. Farkas e hoje está disponível em vídeo tendo alguns títulos sido apresentados através do CANAL BRASIL da TV a cabo).

Teve uma produção mais diretamente ligada ao IEB, que era um filme do Geraldo Sarno e chama-se "Auto de Anchieta" que é um documentário que ele faz a partir da chegada dos ossos do Anchieta a São Paulo. Até ajudei a fazer câmera, ele passando por Aparecida, chegando num tanque de guerra a São Paulo, depois ele reencenou em Embú esse "Auto do Anchieta", com um grupo de atores em que participava o Celso Nunes ...,

..., em 66, junto com o Departamento de Zoologia da (Faculdade de Filosofia, Ciências e Letras) USP, pelo Vanzolini (Prof. Paulo Emílio Vanzolini), ele tinha acesso a uma câmera Arriflex $16 \mathrm{~mm}$, que ficou à nossa disposição, e com uma verba internacional que ele tinha, ... era um projeto sobre uma pesquisa que ele estava fazendo em Angra dos Reis, era pro Geraldo Sarno fazer e eu acabei fazendo, esse projeto em Ilha Grande ${ }^{44}$.

..., e depois, foi um documentário que eu vim a fazer em 67, que teve uma maior participação da Maria Isaura, chamado "O povo do velho Pedro" que é uma documentação de uma comunidade messiânica no interior da Bahia que a Maria Isaura tinha estudado no início dos anos 50 e que nessa época de 67, ela forma um grupo interdisciplinar universitário prá voltar a essa cidade, prá ver como é que estava aquela comunidade não sei quantos anos depois e que envolvia várias áreas: antropologia, sociologia, geografia, economia, psicologia, foi um especialista de cada

\footnotetext{
42 Depoimento coletado em Fevereiro de 2000.

43 "Brasil Verdade" é o título do filme de longa metragem que englobava 4 documentários "Nossa Escola de Samba", "Subterrâneo do Futebol", "Memória do Cangaço" e "Viramundo", que foram ampliados para $35 \mathrm{~mm}$. e lançados em circuito comercial na $2^{\mathrm{a}}$ metade dos anos 60.

${ }^{44} \mathrm{O}$ documentário trata de expedição científica à região de Angra dos Reis, na Ilha Grande, num projeto de pesquisa envolvendo o Departamento de Zoologia, de Geografia e de Geologia da USP. O filme foi realizado em 1966 e tem 60 minutos de duração. O material está disponível, em película 16 mm, no arquivo do IEB.
} 
área e iria uma equipe prá filmar, não prá filmar o resultado da pesquisa, mas o que estava acontecendo naquele momento. Também não era prá eu fazer o filme, era pro Paulo Gil fazer, mas no último momento ele não pode ir e eu acabei fazendo.

Então a participação maior é da Maria Isaura nesse caso e a participação do IEB, foi que eles deram negativo, foi uma confusão, filme sensível, baixa sensibilidade, Kodak, Agfa, e o material de som, as fitas de som, som direto e só isso. Depois com o dinheiro, que veio através da FAPESP, foi possível pagar algumas pessoas, pagar a montagem, magnético perfurado, ...

Quem também ajudava um pouco nessa coisa de acabamento, no caso do filme “O povo do velho Pedro", era aquele Centro de Áudio Visual que tinha na entrada da USP, o CRPE ${ }^{45}$, eles tinham um pequeno estúdio de cinema e foi possível fazer transcrição de áudio, de magnético, sincronizar algumas coisas, então teve uma participação por tabela depois que nós tínhamos feito esse contato com o IEB, por estar no IEB nós pudemos usar uma coisa que normalmente sendo fora da universidade você não poderia utilizar,...

O IEB dava um apoio funcional e no caso desse filme que nós fomos fazer na Bahia eles deram o negativo, o som, e um veículo. Nós saímos de São Paulo e fomos de carro até o interior da Bahia, um dos veículos era da produção e se não me engano eles pagaram a gasolina de ida e de volta. E depois durante todo o acabamento do filme por uma questão também de economia eu editava esse filme num estúdio que tinha alí no Sumaré, era um estúdio da Odil Fono Brasil que não existe mais, e essa pessoa só podia montar à noite então começava às 8 horas da noite e ia até as 2 horas da manhã, então eu fiquei com um jipe à disposição prá montar e levar a pessoa de madrugada prá casa. O veículo nem era do IEB, mas da FAPESP. Essas coisinhas de você conseguir amarrar prá poder viabilizar, mas nunca chegou a ter, que eu saiba, consagrado no orçamento anual uma verba específica prá esse Departamento, o dinheiro ia sendo caçado e arrancado passo a passo.

... , o trabalho de divulgação e distribuição sempre ficou muito precário na medida em que esses filmes já foram feitos no início brando da ditadura e tiveram acabamento depois do AI 5, então esse problema da exibição ficou restrito fundamentalmente ao nível universitário, alguns desses filmes, aí já incorporados à produção do Farkas, em duas ou três dessas atividades da SBPC que faz a cada

${ }^{45}$ CRPE - Centro Regional de Pesquisas Educacionais, órgão do INEP - Instituto Nacional de Estudos Pedagógicos, funcionou na USP, nos anos 60 e é objeto do próximo tópico deste capítulo. 
congresso anual, me lembro que uma vez foi apresentado no Rio, Curitiba eu cheguei a ir... foram apresentados prá esse público dentro de um âmbito de ciências sociais, prá professores, etc. E foram divulgados, e eu participei muito dessa atividade, de 65 até 67, 68 nós fizemos, praticamente de casa a casa, escolas do estado, centros acadêmicos, juntava 40, 50 médicos ou engenheiros, ia na casa de alguém e projetava. Nunca houve a possibilidade de uma projeção mais sistemática.

Eu organizei, em 67, a vinda do Joris Ivens ao Brasil. Eu fiquei amigo dele e apareceu a possibilidade junto à Cinemateca de São Paulo de trazer o Joris Ivens, não me lembro como o IEB entrou nisso, porque na verdade quem produziu fui eu, consegui a passagem, consegui o hotel através do Rubens Paiva que era um dos sócios do hotel, no Rio consegui que ele ficasse hospedado na casa da sogra do Luís Carlos Barreto. Todo o trânsito dos filmes vindos da Europa prá cá e de volta prá lá quem pagou foi a Cinemateca Brasileira na época. O que o IEB fez não me lembro. Eu sei que tem uma entrevista gravada com ele. O original dessa fita está no Museu Segall.

..., mas o IEB nunca consolidou uma base de produção, ..., depois, como não era uma coisa estrutural, regimental, consagrada, formalmente pela Universidade, aquilo acabou se desfazendo na medida em que nós começamos a fazer outras coisas. O IEB na época queria fazer coisas no nordeste, mas não tinha condições de comprar negativo prá participar, então ficou uma relação amistosa, porém sem capacidade de fazer qualquer produção.

No caso específico desse projeto é uma coisa circunstancial e conjuntural, de 2 ou 3 pessoas que perceberam que havia uma possibilidade de entrosamento e ver o que que era possível fazer na época, mas não era uma coisa estrutural."

2.5 - O Serviço de Recursos Audiovisuais do CRPE - Centro Regional de Pesquisas Educacionais “Prof. Queiroz Filho”, de São Paulo.

O Centro Brasileiro e os Centros Regionais de Pesquisas Educacionais foram criados em 1955 e representam mais uma etapa do projeto de grande envergadura para o INEP - Instituto Nacional de Estudos Pedagógicos, que Anísio Teixeira vinha 
realizando desde que assumira a direção do órgão, em 1952. ${ }^{46}$ Bastante detalhadas eram as atividades dos Centros Regionais: biblioteca, documentação e informação, museu, pesquisa, cursos, estágios, elaboração de livros didáticos e serviços de educação audiovisual.

O CRPE de São Paulo, instalado em 1956 na Cidade Universitária, em área hoje ocupada pela Faculdade de Educação, funcionou sempre conveniado à USP. Por lá passaram professores e alunos da Universidade realizando pesquisas e estágios nas diversas áreas de atuação do Centro Regional inclusive no seu SRAV - Serviço de Recursos Audiovisuais.

O uso do cinema educativo, no Brasil, foi bastante acentuado a partir dos anos 40 até os anos 60. Muitas filmotecas de consulados: americano, francês, britânico, canadense, e de empresas privadas: Varig, Shell, esta uma das mais famosas e requisitadas, formaram uma cultura audiovisual em gerações seguidas com seus filmes educativos.

Os Estados Unidos, no esforço de ampliar sua área de influência política e econômica, nesse período crítico de enfrentamento ideológico com o socialismo da URSS (a "Guerra Fria” dos anos 50/60), criou o programa “Aliança para o Progresso". Com recursos do Banco Mundial e abrangendo toda a América Latina, os norteamericanos tinham grande interesse na expansão de seus modelos de produção cinematográfica, embutida aí a sua própria cultura e ideologia. Um dos itens do programa "Aliança para o Progresso", conhecido como "Ponto 4", apoiava acordos de cooperação para a formação de centros de produção audiovisual. Esse acordo veio a favorecer uma experiência significativa de produção de filmes educativos, nos anos 60, a partir de um programa de colaboração entre a Universidade Estadual de Michigan, de seu Centro de Audiovisual e o INEP.

Esse programa foi concretizado, em 1960, com a criação do SRAV do Centro Regional de Pesquisas Educacionais de São Paulo que, através de doações do "Ponto 4", recebeu um conjunto de equipamentos de cinema para produção, montagem,

\footnotetext{
${ }^{46}$ Castro, Maria Helena Guimarães de. O INEP ontem e hoje, INEP, www.inep.gov.br, 1999.
} 
sonorização e copiagem de filmes educativos, ${ }^{47}$ e vários funcionários do CRPE receberam auxílio financeiro do "Ponto 4" para realizarem cursos técnicos em produção cinematográfica nos EUA.

O CRPE propunha o uso dos recursos audiovisuais como auxiliares do ensino, numa perspectiva de instrumental didático. Oferecia a professores de $1^{\circ}, 2^{\circ}$ graus e mesmo de $3^{\circ}$ grau, cursos de capacitação no uso do retroprojetor, do projetor de diapositivos, na produção de materiais impressos, no uso correto do quadro-negro. Outras atividades eram de tradução e legendagem de filmes americanos, para distribuição às escolas e o apoio à produção de filmes educativos.

O responsável pela direção do SRAV - Serviço de Recursos Audiovisuais do CRPE foi o Sr. Chicrala Haidar ${ }^{48}$ que nos relatou um pouco dessa história:

"Quem dirigiu o centro era o Dr. Fernando de Azevedo, foi o primeiro diretor do CRPE. Nessa época o Dr. Anísio estava nos EUA, e quem estava dirigindo o INEP era o Prof. Darcy Ribeiro, muitíssimo amigo do Prof. Anísio. Eu fui conversar com ele, foi um contato muito bom, e ele me disse uma coisa que na hora eu não entendi, mas que demonstra a inteligência dele: 'é uma pena que vocês estejam instalando esse Centro em São Paulo e não na Bahia, num estado menor, que se sentiriam muito felizes e dariam maior apoio. Em São Paulo vocês não vão ter esse apoio'. E foram proféticas essas palavras, não houve realmente um grande apoio nem do Estado, nem da Prefeitura e da USP também muito pouco.

... então nós instalamos e veio muito equipamento dos EUA. Caixas e mais caixas, onde veio o equipamento de som pro cinema, câmeras de filmagem, o que havia de melhor. Os americanos não fizeram economia mesmo, ..., foi no período do Prof. Laerte (Ramos de Carvalho, diretor do CRPE), nos anos 60, o audiovisual teve uma grande expansão.

As atividades do audiovisual eram de dois tipos: treinamento, nós treinamos centenas e centenas de professores de São Paulo, como da América Latina, porque o CRPE mantinha cursos para alunos de todos os países da América Latina e o Áudio Visual deu uns 8 a 10 cursos para alunos de fora. Eram professores do $1^{\circ}$ e $2^{\circ}$ graus $e$

\footnotetext{
${ }^{47}$ Pfromm Netto, Samuel. Telas que ensinam, Campinas, SP, Ed. Alínea, 1998.

${ }^{48}$ Depoimento coletado pelo autor, em fevereiro de 2000.
} 
do ensino superior. Esses cursos tinham uma boa aceitação. ..., os recursos eram por exemplo o flanelógrafo. Com os recursos modernos pode ser que o professor de hoje olhe com descaso, mas essas coisas eram muito importantes e continuam sendo. No ensino primário o flanelógrafo quando bem usado dá resultados muito bons. Flanelógrafo são figuras cortadas, que colocando, ajudam a criar uma história. $O$ uso correto do quadro negro parece uma coisa secundária, mas não é. Publicações, jornaizinhos também têm o seu papel importante e o slide, o diapositivo, o retroprojetor que é de uma importância extraordinária e precisam de uma técnica para serem usados corretamente. Tudo isso era ensinado e demonstrado.

..., demos cursos também de cinema, veio até um grupo da UNESCO aprender aqui a fazer loops, eu era o professor deste grupo, fizemos alguns filmes e eles aprenderam. ..., tínhamos esse tipo de curso: como se escreve um roteiro, eu mesmo dei vários cursos de cinema educativo, à noite, por iniciativa própria e eram muito concorridos por professores da USP. Criei também um Cinema, trazíamos filmes famosos que já não se exibiam mais, Paulo Emílio veio fazer palestras, e no curso de cinema eu enfatizava o roteiro porque eu parto do princípio que se você tem um bom roteiro é capaz de ter um bom filme, se não tem um bom roteiro não adianta...

.... então o audiovisual teve uma expansão muito grande. Trouxemos mais de cem filmes educativos americanos, da Enciclopédia Britânica, do Disney, de diversas empresas para traduzir para o português, mais de cem filmes. Esses filmes foram entregues a uma empresa privada que vendeu por aí, e ficamos com várias cópias de cada filme que emprestávamos à rede escolar de São Paulo. Foi um momento de grande movimento. E produzíamos também filmes educativos pela importância do próprio filme, como treinamento de funcionários para produção de filmes. Tudo em 16 mm. As despesas de produção eram do MEC e do Ponto 4, do governo americano, não da USP.

O fim do Áudio Visual se deu porque o Ponto 4, mudaram as pessoas e os últimos que vieram acharam que o Áudio Visual já tinha cumprido a sua função do ponto de vista dos americanos. Embora nós mostrássemos que ainda deveria permanecer mais tempo para se firmar ..., e aí aconteceu a profecia do Darcy Ribeiro : tiraram eles e não veio nada em troca, nem o Estado nem a Prefeitura. Nem a própria USP. 
Alguma coisa foi para a Faculdade de Educação, alguma deve ter ido para a ECA, não sei. Isso foi de 60 para 70, fins de 60. E aí morreu, acho que não tem mais nada lá, aí morreu o audiovisual."

O Prof. Claudio Zaki Dib, do Instituto de Física da USP, que tem uma larga experiência de trabalho em pesquisa e desenvolvimento de Tecnologia da Educação aplicada ao ensino/aprendizagem, relata sua passagem pelo SRAV - Serviço de Recursos Audiovisuais do CRPE,

“Em 1963 houve um projeto para o ensino de física chamado Projeto Piloto para o Ensino de Física, com 25 professores latino-americanos, com uma consultoria na área psicológica, essa equipe ficou aqui um ano e eu tratei de levá-los para o Instituto de Física e os acomodei lá e trabalhamos durante um ano. Esse projeto tinha como objetivo verificar as possibilidades de desenvolver projetos para o ensino de física para o $2^{\circ}$ grau, pretendia-se criar materiais, naquela época, anos 60, de ensino programado, e pensava-se na produção de 'loops', filmes contínuos, projetados em projetores especiais, em programas de televisão, em filme de $16 \mathrm{~mm}$,

O projeto era da UNESCO, tínhamos de produzir textos e havia em São Paulo, na Cidade Universitária, o CRPE e lá havia um serviço de audiovisual com profissionais muito competentes, tinha o Chicrala Haidar, o Mc Coy, então eles buscaram, o pessoal da UNESCO, o Albert Baez, (Professor do MIT/EUA) autor do projeto, procurou uma aproximação com o Chicrala Haidar e eles trabalhando com esses professores vindos para o projeto piloto, puderam produzir um filme de $16 \mathrm{~mm}, .$. e havia o apoio da UNESCO, naquela época, de U\$140,000, e também da Física, cedendo o espaço. O filme não era tão bom quanto os canadenses, mas era um filme claro "A luz é uma onda", com apresentação do Prof. Paulus.

Quando terminou o projeto eu fiquei o depositário de todo o material e coloquei à disposição do Instituto de Física. Já havia uma coleção de filmes importados, comprados, pelo Prof. Antônio de Souza Teixeira Antunes, que era um dos precursores dessa preocupação no ensino de física, todos esses materiais foram juntados e começamos a filmoteca do Instituto de Física. " 49

\footnotetext{
${ }^{49}$ Depoimento coletado pelo autor em outubro de 99.
} 
Em 1972 o INEP - Instituto Nacional de Estudos Pedagógicos passa por uma reestruturação em decorrência da reforma administrativa do Ministério da Educação e Cultura. Em decorrência é firmado acordo com a USP referente à incorporação do patrimônio do CRPE de São Paulo, à Faculdade de Educação, absorvendo os setores técnicos, administrativos e o pessoal que neles trabalhavam. Daí vem a origem do setor de audiovisual da Faculdade de Educação da USP e alguns dos filmes produzidos pelo SRAV estão hoje depositados no recém criado Centro de Memória da Faculdade.

\section{6 - A (quase) TV Educativa USP/Ford Foundation}

Em 1963 o Prof. Dr. Laerte Ramos de Carvalho, então diretor do CRPE de São Paulo, apresenta um ante-projeto de TV Educativa em circuito fechado na USP, ao Reitor Prof. Dr. Luiz Antônio da Gama e Silva. Tal documento foi preparado para ser apresentado à Fundação Ford que já havia manifestado grande interesse em apoiar financeiramente um projeto de Televisão Educativa para Cursos Básicos na Universidade. ${ }^{50}$

Com a manifestação oficial da Fundação Ford, o Reitor designou o Prof. Laerte para desenvolver o projeto da TV Educativa. Ainda em 63 o diretor do CRPE solicitou a colaboração do Prof. Samuel Pfromm Netto, do Instituto de Psicologia da USP, e do engenheiro eletrônico Nelson Purper Lisboa, do CRPE, para discutirem o detalhamento do projeto.

$\mathrm{Na}$ argumentação do projeto da TVE apontava-se a significativa participação da USP no desenvolvimento cultural e econômico de São Paulo e do Brasil e, por suas condições materiais e de pessoal, destacavam-na como centro irradiador das ciências de onde deveriam partir as novas experiências e iniciativas no campo do ensino superior. As pressões dos setores de produção do Estado exigiam soluções para a formação de pessoal e a USP era chamada a participar da preparação dos profissionais, de diversos níveis de qualificação, necessários ao crescimento das indústrias paulistas. Dizia-se,

\footnotetext{
${ }^{50} \mathrm{O}$ histórico aqui relatado está baseado, principalmente, na leitura do processo RUSP 17534/64, que trata do convênio USP/Ford Foundation.
} 
então, ser urgente o início de experiências no âmbito da USP que levassem à introdução de novos recursos para a multiplicação do trabalho docente e de comunicação simultânea, pois a Universidade ainda estava longe de atender à procura de vagas em seus Institutos. O CRPE, em atividades integradas ao Departamento de Educação da Faculdade de Filosofia, Ciências e Letras da USP, já vinha desenvolvendo pesquisas de utilização de meios de comunicação audiovisual para fins educativos. Por estarem empenhados em programas de formação e aperfeiçoamento de pessoal, produção de material didático, experimentação pedagógica, com apoio da UNESCO, UNICEF, da Aliança para o Progresso e de várias outras instituições, o complexo CRPE/DE colocava-se como o lugar onde deveria se instalar a Televisão Educativa em circuito fechado. Havia ainda a menção especial ao SRAV - Serviço de Recursos Audiovisuais, organizado e equipado para o uso desses recursos em cursos e produção de materiais.

O projeto foi apresentado em agosto de 64 e aprovado pela USP e pela Fundação Ford. Previa-se já para o ano seguinte a realização de cursos de Metodologia Geral do Ensino, Psicologia da Educação, Administração Escolar e Química. Caberia à Fundação Ford fornecer o auxílio de U\$177,000, destinado à compra de equipamentos, aperfeiçoamento de pessoal nos Estados Unidos e assistência técnica. A USP comprometia-se a fazer as adaptações necessárias para a instalação da TV Educativa no CRPE e também da rede de transmissão e recepção. O CRPE cedia parte da área do SRAV, para instalação de estúdio e demais dependências e ainda, financiaria parte da instalação e de contratação de pessoal.

O projeto foi posto em execução, em novembro de 64 o responsável técnico da TV, Nelson Purper Lisboa seguiu para os EUA com a finalidade de efetuar a compra dos equipamentos, selecionados com a participação do diretor da TV Educativa da Universidade da Flórida. Em janeiro de 65 os professores Samuel Pfromm Netto, do IP - Instituto de Psicologia, e Nélio Parra, do Departamento de Educação, viajam aos EUA para conhecerem o sistema de funcionamento, produção e coordenação dos serviços universitários de TVs Educativas. Fizeram-se reuniões de planejamento das aulas que seriam transmitidas, discutiram-se planos de organização e previsões de despesas. Os equipamentos chegaram em novembro de 65, época em que ocorreram a montagem e os ajustes técnicos. Quase um ano depois, em outubro de 1966, ainda sem entrar em funcionamento, a Comissão da TV Educativa recebeu um comunicado do Fundo de 
Construção da Cidade Universitária informando que "por conveniências de ordem administrativa e visando a futura integração da Escola de Comunicações, o estúdio de TV Educativa da Universidade de São Paulo será transferido das dependências do prédio do CRPE para o edifício da Reitoria". ${ }^{51}$

Ora, a Comissão da TV Educativa havia sido preparada para o projeto com viagens e estudos nos Estados Unidos, os especialistas americanos estavam aguardando a data de inauguração da TV, a Fundação Ford não foi informada da mudança, o projeto foi elaborado com base nas instalações e serviços existentes no SRAV/CRPE, e tudo isso é alterado repentinamente por "conveniências de ordem administrativas"?

Chicrala Haidar, diretor do SRAV, não participou desse projeto, seus comentários são escassos,

"Nós tínhamos um funcionário que se envolveu nisso e começou a ir aos EUA, ele tinha muita amizade com o reitor da USP, e nós já tínhamos recebido o equipamento, e ele ficou indo aos EUA para reforçar o negócio e aí perdemos o controle dele, ele ficou indo mais pela USP, e de repente ele começou a andar de carro de luxo, chegou a ser preso, fazia contrabando... Supostamente ele era entendido nisso, também não sei se era, eu hoje tenho minhas dúvidas

Mas quem conseguiu a televisão foi o Dr. Laerte. A TV Educativa deveria ser instalada no CRPE, mas não havia recursos, não havia local para instalação, seria contraproducente, o Áudio estava morrendo, o Ponto 4 estava querendo ir embora, o Dr. Laerte achou melhor a coisa ir prá USP, prá ECA.

Eu pelo menos nunca perdi tempo com a TV porque desde o princípio me pareceu um pouco fora de realidade. Sem dinheiro você não faz nada, fazer imitação não dá”.

O Prof. Samuel Pfromm, em depoimento coletado por este autor, relata:

“A TV Educativa da USP não deu certo em grande parte por causa da própria USP, ela não queria ter uma TV Educativa. Apesar de todo o planejamento de programas, das viagens que fiz aos EUA e Europa para conhecer as TVs educativas,

\footnotetext{
${ }^{51}$ Processo RUSP 17534/64 pág 198.
} 
inclusive de universidades, o projeto não foi implantado por duas coisas, primeiro foi a incompetência do responsável pela área técnica da TV, que agindo sem conhecimento, sem a formação necessária, nem engenheiro era, criou uma situação em que, simplesmente, a TV não funcionava, não havia condição técnica para os equipamentos adquiridos funcionarem e isso com todo o apoio financeiro da Fundação Ford, o que se gastou não foi pouco. E, em segundo, por obscuras razões políticas e de uma hora para outra a TV foi transferida do CRPE para a ECA e lá acabou tendo um uso restrito aos alunos, ao treinamento dos alunos da ECA”.

Fato consumado, a TV foi transferida para o edifício da Reitoria e entrou em funcionamento em novembro de 67, sob direção do Curso de Rádio e Televisão da ECC - Escola de Comunicações Culturais. Em relatórios de atividades da TV Educativa da USP consta a produção de tele-aulas e sua exibição em circuito fechado, restrito às dependências daquele edifício e ao pavilhão B-9, onde funcionava a ECC.

Samuel Pfromm Netto continuou participando da TV Educativa e, juntamente com o Prof. Arrigo Leonardo Angelini, ambos do Instituto de Psicologia, desenvolveram o "Curso Integrado de Psicologia Educacional" através da televisão, em circuito fechado,

“O curso funcionou pela primeira vez em 1969 e abrangeu cerca de mil alunos de todas as áreas do curso de licenciatura da Faculdade de Filosofia, Ciências e Letras da USP. Foram planejados e produzidos 20 videoteipes, cada um com 40 minutos de duração, sendo empregada larga variedade de gráficos, ilustrações, diapositivos, dramatizações, visuais diversos." 52

Esse curso pela televisão deixou de existir quando as disciplinas ministradas para os cursos de licenciatura, de Psicologia da Aprendizagem e de Psicologia da Adolescência, passaram a ser responsabilidade da Faculdade de Educação. Segundo Pfromm Netto "havia uma forte oposição, de um grupo lá na Educação, a qualquer uso de audiovisuais, de televisão, no processo ensino/aprendizagem então, quando o curso foi pra lá eles acabaram largando tudo ...,"53

\footnotetext{
${ }^{52}$ Pfromm Netto, Samuel. Telas que ensinam, Campinas, SP, Ed. Alínea, 1998.

${ }^{53}$ Depoimento coletado em fevereiro de 2000.
} 
O Prof. Samuel relatou mais um episódio sobre projetos de TV na USP,

"Por essa época, final dos anos 60, havendo a disponibilidade técnica de um canal UHF e também de obter a concessão para rádio, nós fizemos o projeto para uma TV UHF e para uma Rádio FM da USP. Foi tudo muito rápido porque o prazo era curto, mas o projeto foi feito e, depois de um longo tempo de tramitação, foi autorizado, mas a própria Reitoria questionou a necessidade da USP ter uma TV Educativa de sinal aberto, falava-se que 'custava muito caro manter uma TV, além disso já existe a TV Cultura em São Paulo, com essa verba dá para contratar vários professores para a universidade’. E assim a USP perdeu o canal UHF e ficou só com a Rádio."

Depois disso, Samuel Pfromm Netto foi para a TV Cultura onde chefiou a Divisão de Ensino por toda a primeira metade dos anos 70. Coordenou o projeto Telescola, participou como consultor da série Vila Sésamo, dando desenvolvimento às suas atividades na área de televisão educativa. (o Anexo III apresenta documentos relativos à tv educativa da USP)

\section{7 - A ECA - Escola de Comunicações e Artes}

A inserção de um tópico sobre a ECA, neste levantamento, visa apenas o registro de seu surgimento e também, apontar o papel que logo assumiu nas questões do audiovisual da Universidade. Sem dúvida que uma avaliação apurada da contribuição da ECA e um detalhamento de sua história é matéria para um trabalho intenso e específico, não cabendo aqui a sua pretensão.

Criada em junho de 1966, pelo Decreto n 46.519, com o nome de Escola de Comunicações Culturais, a nova unidade nasceu no conturbado cenário político brasileiro do regime militar e, como toda a USP, não escapou ilesa a esse ambiente, muito pelo contrário. É interessante resgatar um depoimento do Prof. Dr. José Marques de Melo, apresentado na Mesa Redonda Primeiros Professores da ECA ${ }^{54}$ :

\footnotetext{
54 in Revista Comunicações e Artes, volume 12, pág, 35, 36 e 38, ECA/USP, 1984. Esta edição da revista foi toda dedicada aos 17 anos da Escola.
} 
"Na verdade, esta Escola já nasce com uma série de equívocos. Ouvindo vários depoimentos e histórias contadas pelos colegas sobre a criação da ECA, não é difícil concluir que ela foi imaginada para ser um adorno da Universidade. Uma espécie de jardim cultural. Os jardins verdadeiros já existiam. Faltavam as artes, a cultura, os intelectuais, para enlevar os cientistas. Decide-se então criar um Instituto de Artes, que acaba surgindo como uma Escola de Comunicações Culturais, mais adaptada às exigências de uma sociedade que se moderniza e entra na sua fase industrial. Algum historiador precisa, no futuro, resgatar a motivação que levou realmente a concretizar esse projeto do qual se nutriu a nossa Escola, e a dimensionar os caminhos da distorção. Alguns deles são visíveis e talvez sejam os responsáveis pela produção de cactos em jardins planejados para dar rosas. Primeiro, é preciso lembrar que esta Escola foi pensada à margem da sociedade. Segundo, que ela se rege, desde o começo, de cima para baixo. Terceiro, que ela sempre foi tutelada pela Reitoria e pelos mandatários do poder administrativo, hoje encastelados no Conselho Universitário. Quando o Reitor decide criar uma nova escola que abrigaria o mundo das arte e da comunicação, ao invés de abrir as portas para a participação da comunidade artística, intelectual e dos profissionais da imprensa, do rádio, da televisão e do cinema, institui um grupo de trabalho cuja hegemonia é ocupada por funcionários da própria Universidade, alguns dos quais exerciam funções técnicas na Reitoria. É compreensível, portanto, que a estrutura inicial não tenha refletido o dinamismo das atividades artísticas e comunicacionais presentes na sociedade brasileira. Quando a escola é criada e instalada, em vez de ter a sua administração confiada aos docentes recrutados mediante concurso público, considerados competentes nos diversos ramos do saber que compunham o universo acadêmico da área, põe-se em prática o mecanismo tutelar de remeter todas as decisões fundamentais a um comitê de catedráticos designados pelo Conselho Universitário. Assim sendo, a Escola passa a ser dirigida de cima para baixo e de fora para dentro. A ECA nasce sem autonomia, subordinada às instâncias superiores da USP." 55

"Talvez por essa falta de autonomia é que a ECA não floresce como uma unidade criativa. Imperando a centralização das decisões em órgãos alheios à vida

\footnotetext{
${ }^{55}$ Nos arquivos da Secretaria Geral da Reitoria constam vários registros de atas do Conselho Universitário tratando de encaminhamentos ao CTA, Conselho Técnico e Administrativo da ECA, já nos primeiros anos de sua existência.
} 
cotidiana da Escola, nem sempre as medidas tomadas são compatíveis com as nossas necessidades. Os regulamentos eram aplicados ao pé da letra, quando sabemos que sempre existem brechas, capazes de serem contornadas por legisladores sintonizados com a realidade. É triste, mas é a verdade. A ECA foi criada para ser o jardim da Universidade. Mas o jardim não produz as flores esperadas. Os jardineiros sentem-se tolhidos nas suas iniciativas, nas suas ações, obedecendo instruções vindas de cima, semeando com hesitação, com insegurança. O resultado são flores bravias, agressivas, nutridas no estrume político que o movimento militar de 64/68 lança em todo o país. $\mathrm{O}$ contingente juvenil que converge para a ECA revela inquietação, destemor e efervescência. O ambiente da Escola sempre foi de contestação, de insatisfação e de resistência. A rebeldia dos nossos alunos foi, em alguns momentos, o único incentivo com que contaram os professores que não se conformavam com o arbítrio”.

Considerei válido incluir esse longo trecho do depoimento do Prof. Marques pela sua veemência e clareza na colocação do contexto em que nasce a ECA e, independentemente de ser uma expressão pessoal, aponta mais uma vez os descaminhos por onde passam as questões da comunicação na Universidade.

Por outro lado, desde cedo a ECA passa a constituir um novo vetor para a produção audiovisual da USP. Já em 1967 o então Diretor da ECC, Prof. Dr. Julio Garcia Morejón, foi autorizado pelo Conselho Universitário a manter entendimentos com a Televisão Bandeirantes para a cessão de 02 horas diárias de programação, a fim de ser dada divulgação de atividades desenvolvidas na USP ${ }^{56}$. Em 68, é aprovado um convênio entre a USP e a Secretaria de Cultura, Esportes e Turismo para a realização de um filme documentário, focalizando o município de Embú em seus aspectos históricos, artísticos. $^{57}$

No decorrer de sua história, além das óbvias atividades próprias de suas finalidades de Ensino e Pesquisa na área de Artes e Comunicações, a ECA tem representado significativa contribuição à produção audiovisual da Universidade. Em

\footnotetext{
${ }^{56}$ Conforme consta na ATA 583, de 08.05.67, do Conselho Universitário, dos Arquivos da Secretaria Geral da Reitoria.

${ }^{57}$ Conforme consta na Ata 601, de 05.08.68, do Conselho Universitário, dos Arquivos da Secretaria Geral da Reitoria. Segundo o Prof. Rudá de Andrade, em relato a este autor, o documentário foi uma das primeiras realizações em cinema da ECA e foi dirigido por Roberto Santos, então professor do Curso de Cinema.
} 
cinema, rádio e televisão, as várias unidades desejosas de produzir materiais afins recorrem à ECA em busca de orientação e apoio técnico.

\section{8 - O Laboratório de Recursos Audiovisuais da Faculdade de Arquitetura e Urbanismo}

A Faculdade de Arquitetura e Urbanismo tem a fotografia presente entre seus materiais de ensino e pesquisa desde as primeiras turmas de alunos, nos anos 50. A documentação fotográfica iniciou-se pelas mãos de alunos que registravam monumentos históricos e outras edificações de interesse arquitetônico. Esse acervo foi se formando no Centro de Estudos Folclóricos, do Grêmio da FAU, e posteriormente transferido para a Biblioteca da unidade. No começo dos anos 70 o Prof. Dr. Nestor Goulart Reis Filho, então Diretor da Faculdade, idealiza a criação de um Laboratório de Recursos Áudio Visuais.

O LRAV foi estruturado como um laboratório interdepartamental para atender a todos os professores e alunos da faculdade em suas atividades de ensino, pesquisa e extensão, que envolvessem o uso de recursos audiovisuais. $O$ fato de não estar vinculado exclusivamente a um só Departamento foi um fator positivo para o desenvolvimento do setor, pois a atividade passou a ser de interesse de toda a comunidade da FAU e não de um grupo restrito. Não havia um dono do Laboratório, todos podiam usá-lo.

Cristiano Mascaro, já como ex-aluno da FAU, foi convidado a implantar o novo laboratório. Em depoimento a este autor, ele relata um pouco dessa história ${ }^{58}$,

“... em meados de 73 já tinha me formado, e o Nestor que na época era o diretor, resolveu criar um laboratório de recursos audiovisuais, não só fotografia. $\mathrm{Na}$ época além de fotografia era som, gravar palestras, e audiovisual, aquele sistema de projeção simultânea, dois projetores de slides, uma projeção articulada. E eu fiquei entusiasmado com a idéia.

\footnotetext{
${ }^{58}$ Depoimento coletado em março de 2000.
} 
Eu fui com muito entusiasmo imaginando que seria uma coisa fácil, por quê não? Na medida em que tinha um diretor poderoso no sentido de ser um cara realizador, cheio de idéias, politicamente fortalecido dentro da Universidade, um professor brilhante, então eu imaginava que não teria grandes problemas, o equipamento talvez fosse o grande problema por causa de verba, dinheiro. Mas tinha uma política toda de se comprar equipamento, a FAU já tinha as Hasselblads, tinha uma Linhof, que já eram mais do que suficientes e algumas em $35 \mathrm{~mm}$ que eu não me lembrava, mas não era o equipamento mais caro prá comprar e com o tempo a gente foi estruturando. A primeira coisa era fazer um organograma e um estudo da estrutura desse laboratório. Eu não tinha experiência nenhuma a não ser uma tremenda vontade de participar da criação, um desafio muito gostoso. A gente chegou a ponto, sem nenhum heroísmo, de calção e esguicho, lavava o laboratório porque no dia seguinte ia chegar o armário para equipamento, a gente estava pouco ligando para os tais desvios de função que depois eu descobri que era um terror.

De fato começamos a comprar equipamento. Percebemos que tinha que ter um laboratório dos alunos e um laboratório de produção e um setor de empréstimo. A gente começou a criar fisicamente o laboratório de forma que os alunos tivessem acesso facilmente. Um laboratório para os alunos trabalharem em revelação, ampliação; um setor de empréstimos onde tinha todo equipamento para o aluno poder retirar uma câmera fotográfica e projetor, etc. E um laboratório de produção que atenderia a duas coisas : uma era produzir material didático. O professor tem necessidade e essa é uma capacidade da fotografia, você não precisa levar os alunos prá mostrar o Parque do Ibirapuera, os projetos do Niemeyer, você pode fotografar, ou obras do outro lado do mundo você tira de livros, e assim cria um material didático da forma mais simples possível.

A gente sabia até pelo próprio nome do laboratório - recursos áudio visuais, que o vídeo estava chegando e que a gente precisava ter o equipamento que seria extremamente útil, assim como a fotografia, o áudio visual, para obter e passar informações para os alunos. O vídeo não é minha área, vamos consultar alguém, talvez uma consultoria, qual o melhor equipamento, marca, tipo. Por sorte já estava estabelecido na época o Olhar Eletrônico, de alunos da FAU. Fui na importadora da Sony, mas também não tinha muito o que escolher. Daí que a gente listou todo o equipamento necessário, a ilha de edição, a câmera, não me lembro exatamente qual 
era porque isso deve ter sido em 83, tecnicamente me apoiei nesse pessoal que já sabia alguma coisa. Fui conversar também com o pessoal da TV Cultura.

E precisávamos montar uma equipe, mas era difícil porque tinha que pegar pessoas que não fossem do mercado, mas que tivessem vontade de trabalhar e logo que chegavam lá ou descobriam que lá podia ser uma moleza ou reclamavam do salário, essa era uma discussão diária ... Não sei direito a ordem, mas o Carlo ficou lá um tempinho, depois o Perington, mas sempre um cara que era câmera, editor, tudo ao mesmo tempo, e daí quando o vídeo estava começando, e você já tinha essa experiência técnica e espírito de trabalhar em universidade, vocês começaram a fazer o acompanhamento da obra do MUBE."

Cristiano Mascaro saiu da FAU em 1988, eu havia ingressado no LRAV um ano antes. Sem a chefia, o laboratório continuou por si mesmo, éramos apenas 2 funcionários e atendíamos, na medida do possível, às solicitações de vídeos. Fui ocupando espaço de decisões e conseguindo o remanejamento de funcionários de outros setores que tinham interesse em trabalhar na produção de vídeo. Tais pessoas aprendiam, na prática, a operação dos equipamentos e os procedimentos de produção, depois de 2 ou 3 anos formávamos um grupo de 6 funcionários.

Com o passar do tempo, o setor de vídeo e o setor de fotografia do LRAV já não tinham nenhum trabalho em comum, passando a ter vida própria e, a partir disso, assumimos o nome VídeoFAU - Laboratório de Vídeo da FAU.

A experiência de trabalho que consolidou a formação técnica da equipe de vídeo do Laboratório foi a realização da série de 11 documentários sobre o projeto e a construção do MUBE - Museu Brasileiro da Escultura, ${ }^{59}$ iniciada em 1989 e concluída em 1992. Essa documentação era uma solicitação da Profa. Dra. Sheila Walbe Ornstein, do Departamento de Tecnologia da Arquitetura da FAU, e tinha se iniciado como um trabalho de alunos em visita à área onde começava a construção do Museu. Dada a extensão do trabalho, registrar toda a obra em suas etapas, e para sistematizar as gravações, analisamos o processo construtivo, as técnicas que seriam empregadas e definimos uma estrutura temática conforme convinha às disciplinas do Departamento de

\footnotetext{
${ }^{59}$ O projeto desse Museu surgiu como resposta da Associação dos Moradores do Bairro, Jardim Europa, à intenção da iniciativa privada que pretendia construir, no local, um empreendimento comercial.
} 
Tecnologia da Faculdade. Nosso objetivo era produzir um material didático partindo da velha idéia de que "uma imagem vale mil palavras" e também, que, se não é viável levar os alunos a um canteiro de obras, vamos levar o canteiro à sala de aula. $\mathrm{O}$ trabalho começou apenas com os recursos disponíveis - equipamentos de gravação e edição, transporte da FAU e uma pequena verba obtida junto à FAPESP, pois tratava-se de uma atividade inserida na pesquisa que a Profa. Sheila Ornstein realizava sobre a execução daquele Museu.

A situação de termos um longo trabalho a desenvolver, com gravações periódicas, da terraplanagem à execução da concretagem da grande viga, o registro de depoimentos com especialistas, a realização das edições, levou a equipe a uma prática de produção contínua, por 4 anos, que profissionalizou a todos. Se no início tínhamos um grupo heterogêneo, vindo de áreas diversas da Faculdade, ao final da série do MUBE, formávamos um grupo capacitado à produção de documentários.

Esse material também nos estimulou a abrir uma nova área em nossas atividades. Há algum tempo eu me preocupava com a pouca utilização dos vídeos que fazíamos. Apenas o professor interessado o exibia em suas aulas e o material não tinha nenhuma divulgação. A série de vídeos do MUBE não deveria ter o mesmo destino, não fazia sentido tanto trabalho para ficar restrito a 30 ou 40 alunos, uma vez por ano em uma sala de aula da FAU. Sem dúvida, o material era de interesse de outras escolas de arquitetura, de engenharia e procuramos uma estratégia de divulgação. Com o apoio do Instituto Cultural Itaú, preparamos o lançamento da série, enviando convites, comunicados à imprensa, especializada ou não, e, para nossa surpresa, na noite do evento, no Centro Cultural Itaú, conseguimos um público de umas 60 pessoas. A partir daí sistematizamos a divulgação à imprensa, a remessa de mala direta para nosso público alvo, produzimos um folheto com as sinopses dos programas, incluindo outros vídeos que já tínhamos, e iniciamos a venda do material.

Colocamos dois critérios para decidir se um novo programa entra ou não para distribuição - primeiro é se ele tem "vida própria", se o programa tem uma linha narrativa autônoma que independa de qualquer explicação adicional. Alguns vídeos produzidos para pesquisas científicas são por demais vinculados a um contexto específico, dependem de outras informações que não estão contidas no programa e, se 
exibidos fora desse contexto, apresentam um conteúdo incompleto; o segundo aspecto é de qualidade técnica, mesmo que isso não seja tão importante quanto o conteúdo, mas as imagens e o áudio do programa devem ser inteligíveis sob pena de, simplesmente, inviabilizarem a sua aceitação pelo público.

A idéia estava correta e a resposta ao nosso chamado não tardou, passamos a receber pedidos de fitas de Pernambuco, Minas Gerais, Rio Grande do Sul e, aos poucos, o material ia se espalhando. Numa estimativa de venda, até hoje, de 500 fitas, e que esse material tenha sido assistido por, pelo menos, 100 alunos de escolas de arquitetura e de engenharia, resulta num público 50.000 pessoas. Isso é bastante significativo para a situação anterior, quando ficávamos restritos aos alunos da FAU. É relevante também, que a renda originada da venda desse material é, em parte, revertida para o próprio Laboratório, e em várias situações foi essa verba que permitiu o chamado urgente de assistência técnica para conserto de equipamentos, quando o orçamento da Faculdade não podia nos atender.

A série de vídeos do MUBE havia sido produzida toda com os equipamentos UMatic $^{60}$ do Laboratório. Apesar da boa qualidade oferecida, era evidente a defasagem em relação às novas tecnologias. Os sistemas de edição em computador estavam se disseminando, as câmeras incorporaram o gravador num só corpo e, com uma aparelhagem obsoleta não teríamos como ampliar nossos recursos de tratamento de imagens. Até essa época, 1992, não dispúnhamos de gerador de caracteres nem de efeitos visuais, inventávamos alguma coisa com projeção de diapositivos, com maquetes, num autêntico exercício dos primórdios do cinema. Urgia uma renovação de recursos e sabíamos que isso não viria do orçamento da faculdade.

A Profa. Sheila Ornstein dava prosseguimento à sua pesquisa na área de Avaliação Pós-Ocupação, um campo pouco conhecido fora do âmbito da arquitetura e que trata da qualidade e do desempenho das edificações. Apresentei-lhe, então, a proposta de darmos continuidade à produção de vídeos, vinculando a compra de novos equipamentos, como materiais necessários ao desenvolvimento das atividades da

\footnotetext{
${ }^{60} \mathrm{O}$ formato U-Matic foi o primeiro tipo de video-cassete que surgiu, lançado pela Sony em 1971, e logo foi adotado por todas as emissoras de televisão, no mundo inteiro, por sua praticidade e menor custo em relação ao sistema anterior, de carretéis.
} 
pesquisa, ao projeto que estava sendo encaminhado à FAPESP. Com a aprovação desse projeto adquirimos um sistema de edição, baseado em computador, que permite a montagem dos programas de forma não-linear, com recursos de letreiros, efeitos visuais e demos um salto tecnológico de, pelo menos, 10 anos (o que, nessa área de vídeo, é bastante significativo).

A FAPESP revelou-se uma parceira receptiva à proposta de utilização de recursos de vídeo, integrados à metodologia das pesquisas, e novos projetos se seguiram. As solicitações baseavam-se em dois argumentos - primeiro, a necessidade de registro visual e sonoro dos objetos e/ou situações de estudo e do processamento dessas imagens para sobreposição ou justaposição de informações, através de legendas e outras artes gráficas; e, segundo, a elaboração de um programa, em video-tape, que apresentasse a síntese dos resultados da pesquisa para finalidade de divulgação científica. Outro produto resultante desse trabalho, de valor documental considerável, é a formação de um arquivo de imagens, disponibilizado aos demais pesquisadores interessados, no acervo de vídeo do Laboratório. Utilizamos ainda, com a mesma estratégia de solicitação, o Programa de Apoio à Infra-estrutura da FAPESP, nos módulos equipamentos especiais multiusuários e de infra-estrutura geral, obtendo recursos financeiros para continuar a atualização da tecnologia de áudio e vídeo e para a instalação de um novo espaço de trabalho com estúdio, salas de edição, computação gráfica, etc. Dessa forma dispomos hoje de equipamentos de ótima qualidade de vídeo, em formato Super-VHS e Betacam, e de áudio, no formato DAT (Digital Audio Tape).

Paralelamente a esse processo de reequipamento buscávamos, sempre que possível, inserir, nos pedidos de verbas para pesquisas, as despesas de produção, tais como: fitas de vídeo, transporte, alimentação, materiais de iluminação, serviços de terceiros (assistentes técnicos, elaboração de computação gráfica, locutores, copiagem do vídeo para distribuição, etc). Isso procurava suprir outra carência constante na realização de vídeo na universidade: o custeio da produção, que, geralmente, não é atendido a contento pelo orçamento da faculdade. Os materiais básicos para o funcionamento do Laboratório, tais como fitas de edição, lâmpadas halógenas, filtros de luz etc, e os itens de infra-estrutura, micro-computadores e suprimento genérico, têm sido fornecidos pela FAU, mas as demandas específicas de cada projeto de produção não são entendidas, pela administração da faculdade, como pertinentes ao seu 
orçamento. Caberá portanto, ao interessado o provimento dessas despesas. Como exemplo, cito o caso da pesquisa "Quadro do Paisagismo no Brasil” do Prof. Dr. Sílvio Soares Macedo, do Departamento de Projeto da FAU, que faz um levantamento histórico e da atualidade, na área de Paisagismo, em diversas cidades do país. Esse trabalho, iniciado há vários anos, sempre propôs a realização de uma documentação em vídeo, mas a verba da pesquisa não podia atender às despesas das viagens, estadias, materiais de produção do vídeo, por existirem outros gastos prioritários. No momento aguardamos parecer da FAPESP relativo à suplementação de verba para realizarmos essa documentação, e tem sido nossa recomendação, aos pesquisadores interessados, que façam a previsão dessas despesas em seus projetos de captação de recursos externos.

Mais recentemente, há 3 ou 4 anos, surgiram duas fontes de recursos, na USP, onde é possível solicitar verbas para custos de produção de vídeos: o FCEX - Fundo de Cultura e Extensão, da Pró-Reitoria de Cultura e Extensão Universitária, e o SIAE Programa Sistema Integrado de Apoio ao Ensino, das Pró-Reitorias de Graduação e de Pós-Graduação ${ }^{61}$. Com recursos do SIAE 97 realizamos o vídeo "Taipa de mão, casa de caboclo" e alcançamos um público maior do que normalmente esperamos. Conseguimos a sua veiculação na TV Cultura, e além do público afeto à arquitetura, despertamos o interesse de outras áreas, antropologia, geografia, meio ambiente, e, o que mais surpreendeu, um público geral manifestou uma recepção positiva do programa. Isso chamou a atenção para uma área de produção de vídeos pouco explorada na universidade - a difusão cultural.

Em geral, verificando o acervo de filmes e vídeos da USP, destaca-se a produção de materiais didáticos, dirigida ao ensino superior, e de materiais científicos, para apresentação em Congressos e demais eventos de caráter específico, restritos às áreas do conhecimento interessadas. Vídeos para um público mais abrangente, como documentários de interesse geral, são escassos e sempre carentes de divulgação. Como o nosso trabalho já apresenta uma prática estabelecida para a área de pesquisas e de ensino, estamos estimulando a elaboração de projetos para a área de extensão, com a proposta de produzir vídeos de difusão cultural.

\footnotetext{
${ }^{61}$ Estas iniciativas serão comentadas no próximo capítulo.
} 


\section{9 - Outros casos não menos significativos}

A Universidade de São Paulo, em pouco mais de 6 décadas de existência, criou um espaço estimulante para inúmeras iniciativas, tantas que qualquer relato histórico, conforme seus propósitos, fixará limites para sua amplitude. Outras unidades da USP realizaram produções de filmes e vídeos, destaque especial cabe aos trabalhos realizados no âmbito da medicina, no Hospital das Clínicas, onde Benedito Junqueira Duarte documentou ao longo de 30 anos, dezenas de cirurgias e outras atividades médicas, acumulando prêmios em Festivais Internacionais de Filmes Científicos. A Faculdade de Medicina é assunto para um detalhado levantamento sobre o uso do cinema e demais recursos audiovisuais em seus mais de 100 anos de história.

Com o surgimento do cinema, em 1895, a atividade de documentação visual no estudo do organismo humano ganhou um valioso instrumento e logo na primeira década do século XX se desenvolviam técnicas especializadas e sofisticadas de filmagem de órgãos. A microcinematografia e a possibilidade de aumentar ou diminuir o tempo real, impulsionou as pesquisas e a compreensão de vários fenômenos biológicos, constituindo um vasto campo para a cinematografia científica.

Por outro lado, na Faculdade de Medicina da USP, houve, em meados dos anos 70, um projeto de televisão, para circuito fechado que, apesar de adquiridos os equipamentos, nunca foi posto em funcionamento. ${ }^{62}$

\footnotetext{
${ }^{62}$ Em Abril de 1996, a Profa. Marília Franco, como coordenadora do projeto UNIVÍDEO, foi convidada a uma visita no Edifício dos Ambulatórios do Hospital das Clínicas e pude acompanhá-la aos porões do mau uso da verba pública. A chefia dos ambulatórios do HC queria saber se era possível utilizar os equipamentos lá existentes, adquiridos em meados dos anos 70, para produzir e exibir aos usuários do Hospital programas de educação da saúde. Encontramos um sistema completo de gravação e edição de vídeo, de padrão profissional (formato U-Matic), com 08 câmeras de uma marca renomada (Ikegami), aparelho de telecinagem, etc, totalmente abandonados num ambiente úmido e empoeirado. Não conseguimos recuperar o percurso dessa história, mas o desfecho é dramático - o investimento na recuperação daquele material não compensava devido à defasagem tecnológica que ele apresentava.
} 
Em 1981, o então Instituto de Física e Química de São Carlos, hoje constituindo duas unidades independentes, criou o CDCC - Centro de Divulgação Científica e Cultural, com suas atividades voltadas para a Extensão Universitária, esse Centro vem desenvolvendo programas educacionais junto a escolas públicas da região. O CDCC é muito reconhecido pela criação de materiais de ensino para a área de ciências, principalmente a Experimentoteca, kits para realização de experiências. Dentre as diversas estratégias de ação do Centro - cursos de atualização, observatório de astronomia, cineclube - consta também a realização de vídeos. O material videográfico do CDCC caracteriza-se pela alta qualidade técnica (é produzido com serviços de terceiros), com formato de curta duração (de 6 a 10 minutos) o que é bem apropriado ao uso em sala de aula, linguagem simples, de fácil compreensão.

O IFUSP - Instituto de Física da USP têm um dos maiores acervos de filmes e vídeos educativos da USP, principalmente com materiais adquiridos, mas também com produções próprias. Conforme o relato do Prof. Dr. Cláudio Zaki Dib, no início dos anos 60 o Prof. Dr. Antônio de Souza Teixeira Antunes já utilizava filmes educativos americanos, adquiridos principalmente da Academia de Ciências dos Estados Unidos, para a formação de professores no ensino de física. Além da já mencionada produção de filmes, no Serviço de Recursos Audiovisuais do CRPE, com apoio da UNESCO, o Prof. Zaki Dib relata outra experiência de produção:

“... em 1968 eu começei um programa novo de ensino de Física, tinha duas partes, no $1^{o}$ semestre toda a fundamentação da tecnologia da educação ..., no $2^{\circ}$ semestre eles aplicavam tudo isso no desenvolvimento de um projeto para o ensino de Física. Era uma inovação, faziam textos, fotografias, mas ninguém sabia fazer filmes e havia o Tassara, o Marcelo Tassara, que foi meu aluno de Física. Ele me ajudou, não tínhamos dinheiro, ele e esposa, a Eda Tassara, então os dois trabalharam com meus 
alunos e produziram o primeiro filme do Instituto de Física ${ }^{63}$, usando Tecnologia da Educação ...," 64

O Prof. Dr. Ernst Hamburger, hoje na direção da Estação Ciência, também desenvolveu produções de filmes voltados para o ensino de Física, no começo dos anos 70. Esse trabalho contou com a participação de alunos da ECA e do Prof. Marcelo Tassara que, além de ser formado em Física, é cineasta e professor da ECA. É dele o seguinte relato:

“... na época conheci o Prof. Hamburger logo que eu entrei na Universidade, fui estudar Física, eu nem sonhava em me dedicar ao cinema e o Prof. Hamburger trabalhava com o Prof. Sala (Oscar Sala) no Laboratório de Física Nuclear ..., ...e nós continuamos amigos, tanto é que ele soube que eu tinha entrado na ECA, então ele teve essa idéia de desenvolver uma série de filmes. Na época estava chegando ao Brasil o Prof. Albert Baez e, um desses casos raros: ele é ou era físico, não sei se está vivo ainda, e ao mesmo tempo realizador. Ele se dedicava à realização de filmes educativos. E ele veio aqui e o Prof. Hamburger resolveu criar, criamos um grupo de trabalho de pesquisa e ele me convidou para dirigir esse pequeno grupo. E nós então realizamos uma série de filmes, chegamos a realizar 17 ou 18 filmes. Ainda na época praticamente não se usava vídeo, faz 30 anos .E nós filmamos em película, depois evidentemente fizemos telecinagem, passamos para a mídia eletrônica, mas a captação foi feita em película, com muitas dificuldades, todas as dificuldades inerentes à mídia química.

..., nós usamos recursos da ECA, na época os recursos que nós tínhamos eram relativamente novos, hoje eles não estão propriamente obsoletos, mas estão cansados e velhos em termos de uso e desgaste, e quem trabalhou nisso foram alunos do nosso curso de cinema e do curso de física. Foi um momento de rara felicidade de junção, de colaboração dos dois Institutos : da ECA, através da minha pessoa e o Instituto de Física, através do Prof. Hamburger, ..., os filmes que nós conseguimos realizar, me

\footnotetext{
${ }^{63}$ Segundo relato de Marcelo Tassara trata-se do desenho animado “As leis de Kepler". A ficha técnica indica o ano de 1968, duração de 6 min., bitola 16 mm em P\&B.

${ }^{64}$ Depoimento coletado em outubro de 99.
} 
parece que são 17 filmes, um bom resultado nós colhemos, depois de 3 anos, pouco mais de 3 anos de trabalho. "65

O Prof. Hamburger, depois, continuou esse trabalho, criando a Oficina de Vídeo no Instituto de Física. Não era um setor formalmente constituído na estrutura do Instituto, mas de fato, com recursos por ele captados, adquiriu uma ilha de edição, formato Super-VHS, e uma câmera, e houve uma produção de documentários até o início dos anos 90. Atualmente, com a saída do funcionário encarregado e a obsolescência dos equipamentos, não tem havido mais produções, com recursos próprios, no IFUSP. ${ }^{66}$

Para encerrar este levantamento de experiências passadas, menciono um caso que, não teve maiores repercussões, mas é muito significativo sobre como a USP tem tratado da questão da comunicação por meios audiovisuais.

Em 1989, um grupo de professores da ECA elaborou um anteprojeto de TV Educativa para a Universidade, justificando que:

“A USP - o maior centro de pesquisas do país - tem sido exigida na ampliação de sua interação com a sociedade, o que é tarefa complexa devido à sua enorme e diversificada estrutura. Há no entanto um território a ser plenamente conquistado: o da divulgação científica e cultural, visando o aperfeiçoamento do ensino de $1^{\circ}$ e $2^{\circ}$ graus. E a TV UHF pode ser o instrumento adequado para alcançar tal objetivo.

Baseados neste princípio, promovemos uma investigação junto ao governo federal no sentido de localizar um canal educativo ainda disponível para endereçar tal pleito. A consulta resultou favorável: o canal UHF 53B da cidade de São Paulo poderá vir a ser a sigla da futura TV USP." 67

\footnotetext{
${ }^{65}$ Depoimento coletado pelo autor em novembro de 1999.

${ }^{66}$ Não foi possível um detalhamento da situação do IFUSP por dificuldades de acesso às informações. O Prof. Mikya Muramatsu, que participou das produções do Prof. Hamburger nos anos 70, vem realizando vídeos com o apoio do programa SIAE e recursos técnicos da ECA e do CCE (o programa SIAE será comentado no próximo capítulo).

${ }^{67}$ O Anteprojeto TV-USP foi elaborado pelos professores Carlos Augusto M. Calil (coordenador), Dr. Mario Guidi, Ricardo Herling, Roberto Elizabetsky e Suely Pontes Valente, ECA/USP, 1989.
} 
O documento apresentava uma proposta de estrutura, linhas de programação, planejamento técnico, cronograma e orçamento. Tratava-se de um primeiro estudo mas, já informava a disponibilidade de um canal UHF, o que havia sido verificado junto à FUNTEVÊ, órgão do Ministério das Comunicações responsável pelas concessões de canais educativos. O material foi encaminhado à Reitoria em meados de 1989 e, segundo o coordenador do projeto, não mais saiu de lá, o comentário é lacônico “disseram que não estavam interessados...".

Ora, não podemos deixar de considerar que esta Universidade vem reincidindo no descaso com a questão da televisão. Nos anos 60, numa novela kafkiana, volatizou uma TV em circuito fechado. Imediatamente após, no relato do Prof. Samuel Pfromm Neto, não pleiteou o canal UHF a que tinha direito, ficando só com a rádio FM e, novamente, não se interessa pelo assunto e deixa o carro da história passar à frente, ficando a ver seus bucólicos jardins.

A USP poderia hoje estar transmitindo em rede aberta, com alcance nacional, caso tivesse abraçado o projeto do canal UHF. Seria uma referência às universidades que não tiveram tal oportunidade e hoje engatinham na TV a cabo, mas isso é outra história, ou melhor ...deixou de ser história. 


\section{$\underline{3 \text { - O audiovisual na USP dos anos } 90}$}

A década de 90 apresenta a informática e as telecomunicações como principais protagonistas no mundo das ciências, da cultura, das relações sociais. O futuro é digital, o tempo e o espaço escoam por fibras óticas, mas, fora das vitrines, a vida real continua sendo avaliada pelas disparidades econômicas. As universidades refletem a contemporaneidade, buscam e propõem novas posturas. Na USP renovam-se idéias e projetos audiovisuais. Os anos 70/80, de pouca atividade nessa área, foram como uma fase de contração para liberar o forte impulso dos anos 90. Várias iniciativas, diretamente ou indiretamente relacionadas às questões da produção e do uso do vídeo, ocupam espaços na Universidade, fomentando uma cultura audiovisual.

Surge a Estação Ciência (1987), a Escola do Futuro (1991), o CINUSP (1993), o UNIVÍDEO (1994), o Programa SIAE (1997), a TV USP (1997). Elaboram-se projetos de Educação a Distância (1995), cursos de especialização formam divulgadores das ciências, realizam-se eventos que discutem vários aspectos da relação Universidade/Comunicação. ${ }^{68} \mathrm{O}$ vídeo já não é uma novidade no início dos anos 90 , mas é ainda de muito interesse de professores, alunos e pesquisadores.

\section{1 - Estação Ciência}

A Estação Ciência, o mais conhecido centro de divulgação científica da USP, foi criado pelo CNPq em 1987 e, a partir de 1990, passou para a administração da Universidade. A Estação Ciência atua intensamente na divulgação das ciências, realizando cursos de atualização para professores do Ensino Fundamental e Médio e, também, com exposições para a população em geral conhecer teorias, técnicas e pesquisas científicas. O uso de vídeos está presente nas programações da Estação

\footnotetext{
${ }^{68}$ Cito alguns dos eventos: em 1994, realizou-se um Seminário Internacional "Dez anos de Ciência na TV”, no Centro Universitário Maria Antonia; em 1998, o simpósio “A Comunicação Integrada na Universidade, Políticas, Processos e Meios", promovido pela CCS - Coordenadoria de Comunicação Social-CCS; em abril de 1999, a FEA apresentou "Educação à distância sem complicações", a Estação Ciência realizou a $4^{a}$ Mostra de Material de Divulgação e Ensino das Ciências, com exposição, palestras e simpósio.
} 
Ciência desde o início de suas atividades. Ainda na gestão do CNPq, em 1988, aconteceu a $1^{\mathrm{a}}$ Mostra Internacional da Imagem Científica.

No decorrer da década de 90 consolidou-se a realização de mostras de vídeos científicos, e, na sua quinta edição, o evento Ver Ciência 99 exibiu 38 produções nacionais e internacionais em 5 dias de programação. Neste ano, essa programação foi incorporada ao projeto Mostra Tua Cara, da DREM 4 - Delegacia Regional de Ensino e as escolas (65 unidades na região da Lapa) agendaram previamente a participação nas sessões. O público, de 3.500 alunos, eram, na maioria, do Ensino Fundamental (40\%) e do Ensino Médio (30\%). ${ }^{69}$

A experiência da Estação Ciência indica a necessidade de uma estratégia de incentivos à participação do público nesses eventos. Como não se trata de material de entretenimento, nem apresenta um apelo ao interesse geral, as exibições são dirigidas, principalmente, a estudantes e professores, de qualquer grau, do Ensino Fundamental ao Superior. Na atividade educativa não é apenas o material exibido que, por si só, prédefine o seu público, mas sim a abordagem e o contexto criados em torno de sua apresentação. A Estação Ciência, já conhecida das escolas públicas e privadas, principalmente das regiões norte e oeste da cidade, faz um trabalho ostensivo junto às Delegacias Regionais de Ensino Municipal e com os professores que tem participado dos seus cursos de atualização, para comparecerem, com seus alunos, às exibições dos vídeos. Com a divulgação prévia das temáticas dos materiais busca-se obter o melhor aproveitamento do evento mediante a sua articulação aos conteúdos programáticos que os professores desenvolvem em suas disciplinas. Assim, a realização de Mostras de Vídeos Científicos não se restringe à seleção/programação dos materiais. Antecede o evento um intenso trabalho de divulgação e envolvimento do público que interessa atingir, e segundo seus organizadores, sem a parceria do Centro Cultural Banco do Brasil e da Petrobrás, o projeto Ver Ciência seria inviável.

A prática da Estação Ciência tem demonstrado que a estratégia, junto às escolas de Ensino Fundamental e Médio, dá bons resultados, mas quanto às universidades ainda não há resposta significativa. Mesmo as faculdades de comunicação que poderiam participar na condição de produtores de vídeos, exercitando seus alunos em trabalhos de

${ }^{69}$ Dados fornecidos pela organização do evento. 
divulgação científica, mostram-se indiferentes diante do evento. $\mathrm{O}$ mesmo acontece quando a organização da Mostra Ver Ciência busca uma participação maior da própria USP. Parece que a divulgação científica não tem espaço na pauta de prioridades da universidade.

\section{2 - Núcleo José Reis de Divulgação Científica}

O Núcleo José Reis de Divulgação Científica, vinculado à ECA, foi criado em 1991, com a finalidade de realizar estudos, pesquisas, experimentos destinados a otimizar o uso dos meios de comunicação de massas para a disseminação e popularização da ciência e da tecnologia. ${ }^{70}$

Como primeira iniciativa, o NJR elaborou um programa de pós-graduação em Divulgação Científica, em nível de especialização, destinado a cientistas, pesquisadores, jornalistas e comunicadores envolvidos ou interessados em projetos nessa área. Visava, com isso, proporcionar conhecimentos básicos sobre os processos de comunicação, capacitando os alunos na teoria e na técnica das atividades de divulgação científica. $\mathrm{O}$ programa do curso abrangia as questões envolvidas na elaboração do texto de divulgação, o jornalismo científico, o uso do rádio e da TV na divulgação, a produção de documentários científicos, o papel da divulgação científica nas atividades de Extensão da Universidade e nas instituições de pesquisa.

Foram realizados dois cursos, em 1992 e 93, com a participação de, aproximadamente, 35 alunos, principalmente profissionais da área do jornalismo e de assessorias de comunicação, algumas pessoas da USP (em torno de $20 \%$ do grupo) inclusive este autor. Depois disso, lamentavelmente, a atividade cessou.

O curso foi muito estimulante por trazer à discussão as questões mais urgentes para profissionais que já atuavam na área e propiciou uma compreensão global dos processos e dos problemas presentes na vulgarização do discurso científico. Alguns dos profissionais que hoje estão atuando na comunicação social da USP, Márcia Furtado na

${ }^{70}$ Folheto de divulgação, 1993. 
direção da Agência USP de Notícias, Luis Victorelli na assessoria de comunicação da Faculdade de Odontologia de Bauru, este autor no Laboratório de Vídeo da FAU fizeram tal curso.

\section{3 - Projeto UNIVÍDEO/Cecae}

Em 1988 recebi um folheto do CNPq informando sobre o projeto Universidade Vídeo. Na época já estava trabalhando no Laboratório de Vídeo da FAU USP e fiquei muito interessado nas propostas ali colocadas, afinal encontrava alguém preocupado com as mesmas questões nas quais eu pensava. Ali propunha-se a realização de um cadastramento de filmes e vídeos das diversas áreas do conhecimento, a formação de videotecas, o apoio técnico e financeiro a projetos de produção de vídeos, numa articulação entre o Centro de Referência do IBICT - Instituto Brasileiro de Informação em Ciência e Tecnologia, o CNPq e a FUNTEVÊ - Fundação Centro Brasileiro de Televisão Educativa .

Tudo isso coincidia com minhas preocupações como produtor de vídeos - a formação de acervo, a divulgação dos materiais, o apoio à produção. Fiquei ansioso por um contato pessoal com os organizadores de tal projeto que marcaram o seu lançamento para a $40^{a}$ Reunião da SBPC, em julho daquele ano, na USP. Como estava fazendo um documentário do evento, por solicitação da própria SBPC, não tive muito tempo disponível, mas minhas tentativas de contato foram frustradas por não encontrar ninguém para informar como andavam as propostas anunciadas.

Alguns anos depois, em 93, fui procurado, na FAU, por Nelson De Luca Pretto para uma entrevista sobre produção de vídeos universitários. Nelson ${ }^{71}$ estava desenvolvendo sua pesquisa de doutorado no CCA- Departamento de Comunicações e Artes da ECA e buscava verificar qual era o estado da arte, na área de vídeo, na USP. Naquela ocasião soube, por ser ele um dos idealizadores, que o projeto Universidade

\footnotetext{
${ }^{71}$ Nelson De Luca Pretto, catarinense, formou-se em Física na Bahia, fez o mestrado em Educação, trabalhou no INEP, na FUNTEVÊ e atualmente é diretor da Faculdade de Educação da UFBa.
} 
Vídeo, pela falta do apoio necessário, já em 1988, havia sido abandonado logo após seu lançamento.

A passagem de Nelson Pretto pela USP deixou frutos, mais uma vez a boa semente caiu sobre um solo fértil. As idéias com que ele trabalhava foram acolhidas pela CECAE - Coordenadoria Executiva de Cooperação Universitária e de Atividades Especiais, órgão vinculado à Reitoria, que se interessou em desenvolver um programa de apoio ao uso do vídeo nas atividades de ensino, pesquisa e extensão desta Universidade.

Nelson Pretto não aponta o vídeo como um material didático, visão esta ainda freqüente no meio acadêmico, mas sim como um conjunto de atividades envolvendo: a pesquisa, como núcleo gerador do conhecimento; a distribuição dos vídeos, entendida não só como a remessa das fitas de vídeo, mas como distribuição da informação; a $\underline{\text { utilização, }}$ envolvendo tanto os vídeos produzidos em universidades como a utilização de toda a produção de imagens da sociedade, o que leva este aspecto ao patamar de um novo paradigma na produção audiovisual “... uma vez que o didático passará a ser o uso e não o produto em si"; a produção que, ultrapassando os limites meramente técnicos, alcança as atividades de ensino e pesquisa, e deve permear toda a universidade, e a avaliação, elemento fundamental em todo o processo, vai atuar "não só na identificação do que e como produzir mas também na aquisição de novos equipamentos, na capacitação profissional, na avaliação dos produtos existentes no mercado e do próprio sistema de comunicação”.

O conjunto de ações proposto por Nelson Pretto decorria, em grande parte, da constatação de que existia uma produção de vídeos em universidades brasileiras, mas que eram pouco utilizados e também, de sua concepção sobre o pensar e o fazer audiovisual, visto aí como um elemento de transformação da universidade em um novo organismo mais integrado à sociedade contemporânea, repleta de imagens, comunicação e informação.

A CECAE convidou professores, pesquisadores e técnicos ligados à produção de vídeo, de várias unidades da USP, para opinarem sobre as questões levantadas por Nelson Pretto. Após algumas sessões em que se discutiu a viabilidade de se implantar 
um programa de ações na área de audiovisual na USP, foi estruturado, em meados de 1993, o projeto UNIVÍDEO.

Integrado à CECAE, dentro do Programa Universidade-Universidade ${ }^{72}$, o UNIVÍDEO baseava-se em dois princípios:

- desenvolver ao máximo as condições de cadastramento, difusão e troca de informações sobre o uso e produção de vídeo nas atividades acadêmicas das Unidades da USP

- não propor nenhum tipo de centralização a não ser aquelas referentes ao cadastramento e difusão de informações.

Foi criado um Conselho de Planejamento, composto de Coordenação Acadêmica, Coordenação Executiva, Gerência Técnica e foram convidados representantes de várias unidades da $\operatorname{USP}^{73}$ que já apresentassem atuação na área do audiovisual ou que tivessem a possibilidade de atuar. Constituía-se desta forma um grupo de trabalho e uma estratégia de difusão das informações, pois os representantes das unidades seriam os agentes de comunicação, trazendo demandas específicas e levando informes das propostas de trabalho do UNIVÍDEO.

Inicialmente o Conselho de Planejamento definiu a realização das seguintes atividades:

- em parceria com o SIBI - Sistema Integrado de Bibliotecas da USP, a execução do cadastramento de todo o acervo fílmico/videográfico da USP;

- a capacitação técnica para funcionários, através de cursos de trinta horas, sobre técnicas de produção de vídeo;

\footnotetext{
72 O Programa Universidade-Universidade/CECAE, dedica-se à cooperação inter-universitária e intrauniversitária, através do apoio às atividades conjuntas e na articulação de redes de informação.

${ }^{73}$ As participações foram: Profa. Dra. Marília Franco/ECA (Coordenação Acadêmica), Renato Levi Pahim/ECA, Profa. Laura Martirani/ESALQ, Luiz Bargmann/FAU, Prof. Marcelo K. Zuffo/EP/LSI, Marcia Regina de Sá/EEF, Profa. Dra. Margarida Kunsch/CCS, Maria Izabel Leão/CCS, Rosa Tierno Plaza/IGC, Teodoro Mendes Neto/MAC, Vicente Gosciola/FE,.Luiz Victorelli/HPRLLP/FO Bauru, pela CECAE Regina Carvalho (Coordenadora Executiva) e Renato Campanã (Gerência Técnica).
} 
- a capacitação de professores e pesquisadores, através de cursos de trinta horas, sobre produção de vídeo e seu uso no ensino e na pesquisa;

- implantação do BBS-UNIVÍDEO para agilização da difusão de informações sobre produção de vídeo (técnicas, elaboração de projetos e roteiros, incentivos fiscais, acervos etc);

- planejamento do Selo UNIVÍDEO, em parceria com a EDUSP, visando a distribuição dos vídeos produzidos na USP.

O desenvolvimento das atividades começou com o entusiasmo próprio das iniciativas em que todos estão imbuídos do espírito da realização. O SIBI cooperou efetivamente no cadastramento de filmes e vídeos; a comunidade uspiana respondeu ao chamado para os cursos de capacitação; já o BBS empacou em dificuldades técnicas e de carência de equipamentos, não havia, na época, 1993, a facilidade da internet (hoje o site UNIVÍDEO está acessível). O planejamento do Selo de distribuição só seria viável a partir da análise dos vídeos produzidos pela USP e do conhecimento da capacidade de produção das unidades, de seus projetos de produção, numa avaliação da perspectiva de médio e longo prazo dos programas que poderiam vir a ser distribuídos.

Atualmente é possível conhecer parte do acervo de filmes e vídeos da USP, que contém produções da universidade e também externas a ela, algo em torno de 2.000 títulos, consultando o programa de busca DEDALUS do SIBI. As informações estão disponíveis, mas a difusão do material não ocorre por dois motivos:

1- nem todas as videotecas da USP, por suas normas internas, permitem o acesso ao público externo, somente à comunidade uspiana, isso não favorece a difusão da produção audiovisual da universidade, apenas a sua disseminação no meio acadêmico;

2- não existe um programa global da USP para a duplicação deste acervo e nem para a recuperação de filmes antigos e sua transposição para vídeo (telecinagem), que é um suporte facilitador da difusão.

O cadastramento UNIVÍDEO foi realizado em 1994/95 e não abrangeu todo o acervo da USP, alguns materiais não foram processados como, por ex., os filmes do 
Departamento de Produção de Filmes Documentários do Instituto de Estudos Brasileiros, de meados da década de 60, e que estão catalogados apenas no arquivo do Instituto. Acontece que, em 1997, houve uma atualização do software de busca do SIBI e a base UNIVÍDEO não foi, desde então, carregada com os dados das novas produções. Desta forma uma consulta, hoje, à base UNIVÍDEO, indica que a USP só produziu vídeos até 1995 , nos anos seguintes nada mais consta.

Outro aspecto problemático desse cadastramento foi que o percurso das informações obrigava a sua passagem pela CECAE para que esta as encaminhasse ao SIBI, quando então seriam inseridos no sistema. O procedimento habitual e conhecido para o cadastro da produção da USP é o envio dos dados diretamente às bibliotecas, como se faz com novos livros e monografias. No primeiro momento, em 94/95, com o empenho do grupo de trabalho do UNIVÍDEO, o cadastramento da base UNIVÍDEO funcionou, mascom o passar do tempo, supondo-se que o procedimento estipulado já estava de conhecimento geral, permitiu-se que o processo caminha-se naturalmente. De fato isso não ocorreu. $\mathrm{O}$ envio das informações à CECAE diminuiu, o SIBI trocou de software e as bibliotecas passaram a cadastrar os filmes e vídeos na base Produção da USP, resultando em bases de dados incompletas. Se procuramos por filme/vídeo acessamos a base UNIVÍDEO, desatualizada desde 1996. Se procuramos por filme/vídeo na base Produção da USP encontramos centenas de títulos de publicações relativas ao tema, portanto não existe no momento, uma forma de acesso direto ao acervo de filmes e vídeos da USP.

Atualmente está em andamento um novo cadastramento, pelo SIBI, que utilizando-se da base Monografias, vai inserir a produção da USP realizada em materiais especiais - filmes, vídeos, CD-ROM, diapositivos e outros.

Os cursos de capacitação à produção de vídeos começaram em 1994 e dependiam da colaboração das unidades que participavam do projeto para ceder espaço e equipamentos, pois o UNIVÍDEO não dispunha de infra-estrutura própria. A CECAE forneceu o apoio administrativo e institucional, mas não tínhamos nem mesmo uma sala para as aulas. Até início de 96 o curso foi itinerante, passando pela ECA, ESALQ, FAU, MAC, IQ, FFLCH/LISA. Em junho daquele ano o UNIVÍDEO, numa articulação entre POLI, CCS e CECAE, obtém a cessão de uso de equipamentos de gravação e de edição, 
formato Super-VHS, de propriedade da POLI e, com o apoio da CCS, ocupa uma sala no Anfiteatro Camargo Guarnieri para instalar tais equipamentos e dar andamento à realização dos cursos.

A periodicidade estava na média de quatro cursos por ano, dois por semestre, para funcionários e para docentes/pesquisadores. As turmas, de 12 a 15 pessoas, no caso dos funcionários, tinham como requisito da inscrição que o aluno fosse indicado pela chefia e que suas atividades fossem relacionadas a essa área. A carga horária estava dividida em 5 dias com 3 horas de atividade pela manhã e o mesmo à tarde, compactado em uma semana. Isso gerava problemas de freqüência, pois é difícil, ao funcionário, dispor de uma semana inteira sem interferências de ordem profissional e uma solicitação comum era de que o curso fosse mais espaçado no tempo.

Em 97, por iniciativa do UNIVÍDEO e com a aprovação da Reitoria, o DRH Departamento de Recursos Humanos, passa a apoiar a realização dos cursos como uma das atividades oficiais de treinamento do Departamento contando, inclusive, para pontuação na progressão da carreira dos funcionários. Por um lado isso tornou-se um estímulo às funções afetas à produção de vídeos, mas por outro foi incoerente, pois havia sido implantado um novo Plano de Carreira para os funcionários da USP em que justamente as funções relativas à produção audiovisual, especificamente as de vídeo, foram minimamente contempladas.

$\mathrm{Na}$ área de vídeo a USP tem adotado apenas três funções - de operador de audiovisual, analista de comunicação visual e produtor de comunicação visual. Chama a atenção que estas duas últimas funções não são propriamente designações da área audiovisual e perguntamos, será com isto que a USP resolve a demanda por funções especializadas em produção de vídeo na área da documentação e da divulgação científica?

$\mathrm{Na}$ ocasião a questão foi discutida pelo Conselho de Planejamento do UNIVÍDEO e remetemos um parecer ao DRH, porém nunca houve resposta (o Anexo IV apresenta cópia do documento enviado). 
Os cursos adotaram, desde o início, uma concepção distinguindo o trabalho de funcionários das atividades de docentes e pesquisadores, criando conteúdos programáticos distintos. Curiosamente a sugestão mais indicada, seja por docentes/pesquisadores, seja por funcionários, que, ao final, respondiam a um questionário de avaliação, pedia para aumentar as atividades práticas com equipamentos e, também, queriam continuar com cursos de especialização, principalmente em operação de câmera.

A proposta do UNIVÍDEO era justamente de propiciar, primeiro, uma formação básica sobre o processo de produção, os recursos técnicos requeridos e os usos possíveis para o vídeo na universidade e, depois, continuar a capacitação com cursos específicos em captação de imagem e som, em edição, em elaboração de projetos e roteiros

Os cursos demandam recursos financeiros, há custos de remuneração dos professores, alguns eram profissionais do mercado de produção de cinema e vídeo, e também custos de materiais de apoio, apostilas, fitas de vídeo. A CECAE nunca pode provê-los a contento e na falta de outro apoio os cursos para docentes e pesquisadores também não tem mais se realizado. Essa que foi uma das principais e mais significativas iniciativas do UNIVÍDEO e no momento aguarda soluções.

É pertinente inserir aqui um trecho do depoimento do Prof. Mário Guidi,

“..., eu comecei a ministrar cursos, que eu acabo ministrando até hoje na Psicologia, na ECA, sobre utilização de vídeo, de cinema na pesquisa científica. A facilidade do vídeo traz uma outra conseqüência, quer dizer, o vídeo realmente passa mais a ser operado pelo pesquisador e não por um operador visível. No caso do cinema, não tanto por uma questão filosófica, metodológica da ciência, mas por uma questão da maior dificuldade instrumental, quer dizer, se alguém queria fazer alguma coisa em película era o Mário Guidi que tinha que ir ali filmar porque realmente operar uma câmara ,mesmo que uma câmara 16mm, mas já era suficientemente complexo para o próprio pesquisador não se animar muito a tentar operar sozinho o equipamento. O vídeo desde o início facilita esse lado, que aliás é o lado que eu sempre enfatizo, é muito mais fácil você transformar o pesquisador num operador de vídeo para o seu trabalho, do que transformar um operador de vídeo em pesquisador. Então 
se você quer ter um camarada que opera um vídeo para fins de pesquisa, como operador você tem uma dificuldade muito grande. Você não vai encontrar esse camarada, você vai ter que formar esse camarada, porque na verdade você vai encontrar operadores de vídeo para o vídeo, vamos dizer, comum, que nós conhecemos, quer dizer, atividades de vídeo voltadas para a parte artística, para a parte espetáculo, para a parte cênica de uma maneira geral.

Para você transformar um operador de vídeo num sujeito desses que vai registrar comportamento social de macaco, você vai ter que refazer a cabeça do sujeito, porque na verdade a operação do equipamento em si não é uma coisa muito complicada, então o que faz hoje um bom câmara de vídeo não é tanto a habilidade dele de operar o equipamento em termos de fotometria, em termos de problemas da utilização de diferentes objetivas com distâncias focais diferentes, com eventuais filtros, como acontecia na cinematografia, mas é muito mais a sensibilidade dele ter a facilidade de ver a cena que vai ser captada, que interessa e dirigir a câmara no sentido de registrar os aspectos mais significativos daquela seqüência, daquele conjunto. Então você ensina o sujeito a operar uma câmera de vídeo, dali prá frente o problema não é como operar, é realmente a sensibilidade que o sujeito possa ter, a noção de timming do processo, o quanto uma cena deve ser mais demorada, o quanto deve ser mais rápida, mas não é o problema técnico da operação da câmera, quando antes o cameraman cinematográfico ele era realmente um cara ,só prá carregar, dependendo do tipo de câmera, Mitchel por exemplo, se o cara não fosse de circo ele dançava, ele queimava uma bobina de filme na hora de carregar a câmera. Descarregar a câmera, tinha que fazer com saco preto, quando você tava no campo. Coisas que realmente exigiam toda uma ...e isto acaba.

Isso facilita então aquilo que inclusive é importante na ciência, na pesquisa até na educação, que o próprio pesquisador seja capaz de operar o seu equipamento porque ele sabe realmente inclusive aquilo que é importante no operador de vídeo, ele sabe prever a seqüência e se colocar com a câmera não como alguém que corre atrás da imagem, mas alguém que se adianta à imagem que vai ocorrer, porque ele já tem mais ou menos a previsão do procedimento. Se ele tem uma bruta prática de socialização em primatas, naquela particular espécie de primatas, ele vai se adiantar 
num certo sentido ao processo se posicionando com a câmera, preparando a câmera para o possivel desenrolar de uma situação que é de interesse. "74

Em entrevistas com alguns dos participantes dos cursos, procurando saber do aproveitamento posterior, foi comum o comentário da sua validade como formação genérica, mas ficou como uma atividade isolada. $\mathrm{O}$ aprendizado não era colocado em prática, as unidades, não dispondo de equipamentos para a produção (geralmente tem uma câmera, mas falta o sistema de edição) pouco podiam fazer.

Os equipamentos cedidos pela POLI estavam destinados também a apoiar projetos de produção que fossem apresentados ao UNIVIDEO, pelas unidades interessadas. As normas de uso dos equipamentos definiam os procedimentos para a solicitação de gravações e de edições e foi estipulado um custo para tais serviços. A taxa, de $30 \%$ do valor de mercado de locação de equipamentos, era destinada à manutenção dos mesmos e de outras despesas envolvidas nas atividades do UNIVÍDEO (seguro dos equipamentos, cursos, apostilas, assessorias, etc). Porém essa possibilidade de produção foi pouco difundida e os projetos apresentados, alguns executados, ainda encontravam outra dificuldade básica, o único funcionário da CECAE, designado para o UNIVÍDEO e habilitado à operação dos equipamentos, tinha também funções em outras atividades da CECAE. A falta de apoio operacional/financeiro e por termos poucas pessoas dedicadas à execução das atividades, ninguém em tempo integral, foi minando o empenho do grupo e o Conselho de Planejamento foi se esvaziando.

Outra atividade realizada pelo UNIVÍDEO foram as duas Mostras de Vídeo da USP, em 1994 e 95. Em 1996 as duas Mostras se fundiram e foram apresentadas em alguns campi do interior. Com isso acontecendo logo no início do projeto pudemos verificar a capacidade de produção de vídeo das unidades e colher subsídios para uma análise da viabilidade de implantação do Selo UNIVÍDEO, um dos objetivos do projeto.

Na $1^{a}$ Mostra, em outubro de 94 no Anfiteatro Camargo Guarnieri, foram exibidos 27 vídeos em dois dias de programação. Participaram 11 unidades, algumas com vários programas, onde se destacam a diversidade da qualidade técnica e do uso da linguagem videográfica. A relação delas aponta para uma predominância de produções

\footnotetext{
${ }^{74}$ Depoimento coletado pelo autor em setembro de 1999.
} 
realizadas nas áreas de Biociências e de Humanas - 24 vídeos. Do conjunto de programas 10 são da área de Biociências, destacando-se a Saúde com 8 vídeos. A relação é a seguinte:

Escola de Enfermagem - 4

Hospital de Reabilitação de Bauru - 4

ESALQ - 1

Instituto de Biociências - 1

$\mathrm{ECA}-5$

FAU -3

FFLCH/Geografia - 1

Faculdade de Educação - 1

POLI - 1

IFQ - São Carlos - 1

Instituto de Geociências - 1

Participaram 4 co-produções, duas da ECA/FAU, uma ECA/ESALQ e uma FAU/Inst. Biociências.

$\mathrm{Na} 2^{\mathrm{a}}$ Mostra, realizada em outubro de 95 no Auditório da FEA, a distribuição dos 18 vídeos, pelas 3 áreas das ciências, foi a seguinte:

Instituto de Biociências - 2

Hospital de Reabilitação de Bauru - 1

Escola de Enfermagem - 1

Faculdade de Saúde Pública - 1

CDCC - São Carlos - 3

ESALQ - 1

$\mathrm{ECA}-3$

FAU -2

FFLCH/Sociologia - 1

POLI - 1

Duas co-produções da ECA, com o Museu Paulista e com o SIBI.

Com essas Mostras pudemos constatar que os vídeos produzidos na USP são dirigidos a contextos e públicos específicos, são documentários que objetivam 
determinados grupos e não a divulgação generalizada. Ficou claro também que o interesse do público não se dá apenas pelo mero anúncio da exibição dos vídeos que a universidade produz - o comparecimento foi praticamente nulo nos dois eventos. A questão de público está mais relacionada à especificidade dos materiais exibidos e à necessidade de incentivar as pessoas diretamente interessadas nas temáticas apresentadas a participarem do evento e isso implica numa estratégia de comunicação mais ampla, extra USP, envolvendo outras escolas em atividades programadas.

A Estação Ciência vem realizando a Mostra Ver Ciência há alguns anos e busca, sempre, articulações com as escolas públicas para levar os alunos às exibições dos programas que são, inclusive, de alta qualidade e de vários países, e mesmo assim ocorrem sessões com baixa freqüência.

O material enviado pelas unidades para participarem das Mostras permitiu a análise da qualidade técnica e dos tipos de vídeos que a USP vinha produzindo, o que era fundamental para o planejamento do Selo UNIVÍDEO. O quadro apresentado evidenciou uma enorme disparidade de qualidade técnica entre os programas, com realizações feitas em formato VHS (de uso doméstico) e outras em Betacam (utilizado pelas emissoras de TV). Alguns dos vídeos tinham o tratamento de conteúdo e a produção muito bem resolvidos, mas a imagem e o som muito precários, comprometendo a sua copiagem para distribuição.

Outra questão avaliada foi sobre a descontinuidade da produção de vídeos pelas unidades da USP, considerando que um plano de distribuição, em larga escala e de âmbito nacional, deveria contar com um número mínimo de novos programas a serem lançados periodicamente. No material que recebemos para as duas Mostras e no contato que tínhamos com funcionários técnicos e professores, nos cursos de capacitação, nada indicava que a produção desta ou daquela unidade era sistemática e constante, muito pelo contrário, verificava-se que eram trabalhos isolados e resultantes de um enorme esforço das pessoas envolvidas. Nesse sentido, o dado mais significativo que pudemos perceber é que o interesse em produzir vídeos é muito grande e as dificuldades também.

A inexistência de produções sistemáticas nas unidades da USP, como précondição para estruturarmos o Selo UNIVÍDEO, comprometia sua validade. Seria 
necessário, antes, melhorar as condições técnicas e também de apoio financeiro, para que as unidades passassem a realizar produções com freqüência e com melhor qualidade de imagem e som.

Em 1994 o UNIVÍDEO organizou a realização da Mostra Internacional de TV e Vídeo "Ver Ciência", no Centro Universitário Maria Antônia, em parceria com o Centro Cultural Banco do Brasil e a empresa Mediatech, do Rio de Janeiro. Nessa Mostra foram exibidos 31 programas, provenientes de nove países, para escolas de $1^{\circ} \mathrm{e}$ $2^{\circ}$ graus. Simultaneamente, também organizado pelo UNIVÍDEO, realizou-se o Seminário Internacional “Dez anos de Ciência na $T V$ ”, em parceria com a Academia Brasileira de Ciências, com a participação de 24 convidados de 4 países. Na ocasião foram extensamente discutidas as questões da concepção, da produção e da distribuição de programas de divulgação científica. No evento, participaram representantes ${ }^{75}$ da BBC, de Londres, da Rede POP/UNESCO, da TV da Venezuela, da Academia Brasileira de Ciências, da Fundação Roberto Marinho, da UNESP, da UFPA, da UnB, unidades da USP (HRB, IQ, FAU, ECA, IF, Estação Ciência, CECAE), as empresas Mediatech e Vídeociência, do Rio de Janeiro e o, então Pró-Reitor de Cultura e Extensão, Prof. Dr. Jacques Marcovitch.

Momento auspicioso pela presença de profissionais e cientistas que vem trabalhando com a divulgação científica nas várias mídias, com predominância da televisão e do vídeo, nos dois dias do evento registramos em áudio todas as discussões e proposições, faço um resumo a seguir.

\section{Considerações preliminares.}

No limiar do século XXI é urgente estabelecer um novo paradigma para a Ciência na sociedade. Esse novo paradigma coloca a Ciência e por extensão seus produtos, como um legítimo bem social, econômico e cultural desejado pela sociedade. $\mathrm{O}$

\footnotetext{
${ }^{75}$ Os representantes foram: Richard Reisz, BBC-Londres; Edoardo Martinez, do programa Expedicíon, Caracas, Venezuela; Lucila Martinez, Rede POP/UNESCO, Diógenes de Almeida Campos, Paulo de Goés, Beethoven Luiz Teixeira, Academia Brasileira de Ciências; Luiz Victorelli, HRB/USP; José Atílio Vanin, IQ/USP; Luiz Bargmann, FAU/USP; Marília Franco, ECA/USP; Ernst Hamburger, IF/USP; Manoel Chaparro, ECA/USP; Ary Plonsky, CECAE/USP; Reinuncio de Lima, UNESP; Carmem Lúcio José, UNESP; Yara Borges Caznok, UNESP; Luiz Gonzaga Mott, UnB; Juvêncio de Almeida Câmara, UFPA; Nilson P. de Oliveira, UFPA; José Renato Monteiro, Mediatech/RJ; Sergio Brandão, Video Ciência/RJ; Maria Theresa Walcacer e Mônica Teixeira, Fundação Roberto Marinho.
} 
conhecimento científico, como produto das atividades realizadas por cientistas com o apoio e consentimento de toda a sociedade, deve dispor de canais de distribuição que alcancem todo o corpo social.

É legítimo que as ações de divulgação científica, que envolvem cientistas, comunicadores, dirigentes políticos e o público, sejam o instrumento de implantação desse novo paradigma. Tais ações passam, necessariamente, pela pauta das decisões políticas do país.

É legítimo e urgente também, que as universidades e institutos de pesquisa, como principais representantes da atividade científica financiada pela sociedade, estabeleçam estratégias de socialização do conhecimento através da divulgação científica.

\section{Diretrizes para as ações de divulgação científica:}

- a divulgação científica deve ser valorizada por cientistas, comunicadores, dirigentes políticos e o público como uma prática da cidadania,

- as questões da divulgação científica devem ser levadas à pauta das instâncias decisórias, não se restringindo a grupos de especialistas,

- deve-se buscar o financiamento da divulgação científica tanto em agências institucionais de fomento à ciência como no setor privado,

- a divulgação científica deve ser dirigida a toda a população, em suas diversas camadas sociais e faixas etárias,

- a divulgação científica deve trabalhar com as informações e o conhecimento, mas também com o esclarecimento das metodologias das ciências e o papel do cientista no desenvolvimento científico,

- as atividades para a formação de profissionais de divulgação científica devem ser descentralizadas, com abrangência nacional,

- os produtos de divulgação científica devem buscar narrativas e tratamentos audiovisuais que estimulem o desejo de consumir ciência na população. 


\section{Principais propostas:}

- realização de cursos de especialização em divulgação científica para profissionais da comunicação,

- realização de cursos de especialização em divulgação científica para cientistas, pesquisadores e professores das universidades e institutos de pesquisa,

- criação de mecanismos que valorizem os trabalhos de divulgação científica na carreira dos cientistas, no âmbito das universidades e dos institutos de pesquisa

- as agências institucionais de financiamento da ciência devem criar programas específicos para apoio à divulgação científica,

- as agências institucionais de financiamento da ciência devem incluir um item específico de divulgação científica nas exigências dos relatórios dos pesquisadores,

- as agências financiadoras devem ser assessoradas por avaliadores de projetos especializados em produtos audiovisuais e em divulgação científica.

A divulgação científica é uma das áreas de atuação da produção de vídeos na Universidade, e as conclusões e propostas apresentadas nesse evento repercutem sobre várias das questões apontadas nesta dissertação.

No decorrer das atividades do UNIVÍDEO, o Conselho de Planejamento deliberou a realização de um levantamento das condições técnicas de produção de vídeo nas unidades da USP. O Diagnóstico UNIVÍDEO seria uma detalhada verificação da infra-estrutura de produção existente na universidade em termos de - equipamentos, técnicos especializados, usos correntes dos materiais de vídeo, projetos em andamento e futuros. Pretendia-se fazer um Raio X do estado da arte do vídeo na USP e avaliar seu potencial de produção, principalmente na perspectiva do estudo da viabilidade do Selo de distribuição. Nesse trabalho assumi uma função executiva, preparando o questionário e trazendo insumos para a discussão do trabalho no Conselho de Planejamento. Essa atividade, num primeiro momento colocou-se como o foco principal do que seria a minha pesquisa para o mestrado, porém com a interferência de fatores de ordem profissional e pessoal, não pude desenvolvê-la com a dedicação necessária, ficando para um segundo plano dentro do escopo do meu trabalho. 
Optamos por um questionário de auto-preenchimento a ser enviado pela CECAE aos Presidentes das Comissões de Cultura e Extensão das unidades da USP. Buscávamos verificar as seguintes questões:

1- Existe, na unidade, um setor específico para atender a demanda de serviços de vídeo?

2- Quais os equipamentos de vídeo de que a unidade dispõe?

3- A unidade tem funcionários técnicos capacitados à operação dos equipamentos?

4- A unidade tem projetos para a área de vídeo (instalação de equipamentos e/ou produção)?

5- Qual o grau de necessidade da unidade para: acervo de vídeos; aquisição de equipamentos; formação técnica para funcionários; verbas para custeio de produções.

6- Qual a frequiência do uso dos recursos de vídeo em atividades de Ensino, Pesquisa e Extensão?

Em junho de 96 remetemos os questionários às unidades. O desenvolvimento desse levantamento continuou a ser feito, então, por um aluno de graduação selecionado pelo UNIVÍDEO, bolsista da COSEAS, que passou a monitorar, por telefone, a recepção e o encaminhamento dos questionários. Um dos aspectos que nos chamava a atenção é de como se daria a coleta das informações dentro da unidade, visto que é comum a existência de recursos vinculados exclusivamente a uma pesquisa, a um laboratório, e que, eventualmente, nem seriam mencionados nesse levantamento.

Foram remetidos 47 questionários obtendo-se 10 respostas completas, 24 incompletas e 13 unidades não deram retorno. O material incompleto foi concluído através de contato telefônico com a pessoa indicada no questionário como responsável pelas informações. As unidades que não retornaram o questionário foram procuradas, mas a situação permaneceu a mesma. Portanto, num conjunto de 34 Unidades 
pesquisadas, 26 de Ensino e Pesquisa e 08 de Extensão e complementares, ${ }^{76}$ obtivemos os seguintes dados:

1- Do universo pesquisado, 19 unidades possuem um setor específico para atender a demanda de serviços de vídeo.

2- As unidades pesquisadas tem os seguintes equipamentos:

- todas as 34 unidades tem televisor e video-cassete para exibição de programas, num total de 169 conjuntos. Apenas 08 unidades tem projetor de vídeo (“telão");

- 28 unidades dispõe de câmera de vídeo, sendo 68 aparelhos tipo VHS, 22 do tipo Super-VHS e 01 do tipo Hi-8, num total de 91 câmeras;

- apenas 07 unidades pesquisadas tem equipamento de edição de vídeo, sendo 04 sistemas completos e 03 sistemas incompletos (que não dispõe de gerador de caracteres ou de mesa de efeitos).

3- Essas unidades contavam com 22 funcionários especializados para os serviços de vídeo e 35 não especializados atuando na área.

4- 12 unidades apontam projetos para a área de vídeo, em andamento, 7 projetos para objetivos de instalação de equipamentos e 5 projetos de produção de material didático e documentação de pesquisas.

5- A avaliação das necessidades das unidades na área de vídeo apresentou os seguintes dados:

- $\quad 91 \%$ tem necessidade média ou alta de aumentar o acervo de vídeos;

\footnotetext{
${ }^{76}$ As Unidades pesquisadas foram: Escolas - de Educação Física, de Enfermagem, de Enfermagem de Ribeirão Preto, de Engenharia de São Carlos, Superior de Agricultura “Luiz de Queiroz" de Piracicaba; Institutos - Astronômico e Geofísico, de Estudos Avançados, de Estudos Brasileiros, de Física, de Química, de Matemática e Estatística, de Oceanografia, de Psicologia, de Ciências Matemáticas de São Carlos; CEBIMAR de São Sebastião; Faculdades - de Educação, de Ciências Farmacêuticas, de Ciências Farmacêuticas de Ribeirão Preto, de Filosofia, Letras e Ciências Humanas, de Filosofia, Ciências e Letras de Ribeirão Preto, de Medicina de Ribeirão Preto, de Odontologia de São Paulo, de Ribeirão Preto e de Bauru, de Saúde Pública, de Zootecnia e Engenharia de Alimentos; outras Unidades - Museu Paulista, Museu de Arqueologia e Etnologia, Museu de Arte Contemporânea, de Zoologia, Estação Ciência, CDCC de São Carlos, SIBI e CEPEUSP.
} 
- $76 \%$ tem necessidade média ou alta de adquirir equipamentos para produção de vídeos;

- $67 \%$ tem necessidade média ou alta de aprimorar a formação técnica dos funcionários na área de vídeo

- $\quad 76 \%$ tem necessidade média ou alta de verbas para custeio de produções de vídeos

6- $22 \%$ das unidades utiliza periodicamente os recursos de vídeo na produção de programas para o Ensino, a Pesquisa e a Extensão e, 38\% não utiliza periodicamente, mas pretende utilizar.

A análise dos dados coletados permite-nos as seguintes considerações:

1- a existência de setores dedicados à área de vídeo, em mais da metade do universo pesquisado, é um fator positivo para viabilizar uma estrutura funcional de trabalho de produção de programas. Com setores já inseridos no organograma da unidade é possível iniciar a formação de uma equipe de funcionários e orientá-los para uma especialização técnica. Esta é uma primeira condição para garantir um desenvolvimento profissional que corresponda ao empenho e ao apuro técnico necessários à produção audiovisual.

2- a relação dos equipamentos apresentada indica um acentuado desequilíbrio dos recursos de gravação para os de edição. Essa situação é prejudicial à produção de programas, pois grava-se muito material e edita-se muito pouco, o que é revelador de uma demanda mal esclarecida. Se as solicitações restringem-se às gravações, não havendo interesse na edição do material, supõe-se que esse material não está sendo produzido para ser apresentado a um público. Mas então para que serve a gravação?

Isso não se aplica no caso de registro de atividades de pesquisa que podem até ser utilizadas em seu estado bruto, porém nas gravações de palestras, seminários, devese prever a edição do material para sua adequação a contextos de exibição. A edição, eliminando partes desnecessárias ou redundantes, com a inserção de letreiros informativos, permitirá um uso mais amplo do material, até mesmo fora da escola 
que produziu tal documentação. Cabe ressaltar também, como fator negativo no item equipamentos, a predominância de câmeras do tipo VHS (75\%), que é destinado ao uso doméstico e oferecem baixa qualidade de registro e prejudicam acentuadamente o seu processamento de edição e reprodução.

3- os dados apontam a existência de mais funcionários não especializados, 35, atuando na área de vídeo do que os especializados, 22.

Isso é decorrência de uma série de fatores: primeiro que, na contratação de um técnico especializado em produção de vídeo a universidade não é concorrente no mercado profissional, pois a remuneração, comparativamente, é muito baixa, portanto poucas pessoas já capacitadas serão candidatas a tais vagas; segundo, recorre-se freqüentemente ao remanejamento interno, quando aproveita-se o interesse de um auxiliar administrativo, por exemplo, e se lhe oferece uma nova função. Algumas unidades da USP, nessa estratégia, arcam com os custos de cursos para formar o novo técnico, outras contam apenas com a dedicação e a curiosidade do interessado na leitura de manuais e revistas. Nessa situação a sua classificação como especializado ou não, depende tanto de seu reenquadramento funcional como do reconhecimento, por parte da administração da unidade, de sua capacitação técnica.

4- o número total de projetos indicados nos questionários, de 12 unidades, é significativo em relação ao universo pesquisado, $35 \%$.

Caberia verificarmos, nos projetos de equipamentos de 07 unidades da USP, quais foram os procedimentos para a escolha da tecnologia, pois esta é uma área que sofre mudanças rápidas, com alto índice de obsolescência, onde o custo não pode ser o critério absoluto para a definição de tipos e modelos. Como levantamento sumário este item da pesquisa indica mais um potencial de desenvolvimento e um interesse das unidades no uso dos recursos do vídeo em suas atividades. Só um acompanhamento detalhado permitiria uma avaliação de seus propósitos e resultados.

5- os dados relativos às demandas das unidades são reveladores, também, do interesse e de algumas especificidades da área de vídeo. A questão do acervo de 
vídeos aponta para a enorme necessidade de produção de materiais educativos. A especialização das ciências, a abertura de novos campos do saber, implica numa divisão minuciosa de temas e subtemas, conteúdos específicos, de forma que, se uma biblioteca de Física contém milhares de volumes, sua videoteca também será vasta. As solicitações de programas nos acervos universitários, são predominantemente de materiais didáticos vinculados a disciplinas, os programas genéricos são pertinentes à difusão cultural, às atividades relacionados ao público leigo. Disso surge uma alta demanda por vídeos específicos que não seria suprida apenas com a produção da Universidade, mas também, com a aquisição de materiais produzidos fora dela.

As demandas por equipamentos, formação técnica para funcionários e de verbas para custeio de produções apontam, de modo geral, para o interesse das unidades em desenvolver o uso dos recursos do vídeo em atividades de Ensino, Pesquisa e Extensão e para a necessidade da Universidade de estabelecer estratégias de apoio financeiro de longa duração às unidades.

6- os dados sobre o uso periódico dos recursos de vídeo para a produção de programas, somente 7 unidades o fazem periodicamente e 13 pretendem fazer, expressa a baixa capacidade da universidade em atender à demanda de materiais educativos apontada no item anterior, porém é compatível com a infra-estrutura instalada visto que são apenas 6 as unidades que dispõe do equipamento de edição.

Esse levantamento realizado pelo UNIVÍDEO, entre junho e outubro de 96, é um retrato que deve ser visto apenas como uma referência daquele momento.

Alguns problemas perturbaram a qualidade das informações: primeiro, o modelo de auto-preenchimento revelou-se falível para representar tudo o que uma unidade universitária realiza nesta área, ao ser respondido por apenas uma pessoa do local que não conhecesse todas as situações dos recursos de vídeo da unidade, muitos deles dedicados exclusivamente a um só pesquisador (eventualmente não compartilhado e nem divulgada a sua existência). Seria necessário o acompanhamento da coleta das informações nas unidades por uma pessoa capacitada à verificação técnica de equipamentos, das formas de utilização e de produção e dos projetos em andamento; este foi um segundo problema pois, a CECAE não dispôs recursos financeiros ao 
UNIVÍDEO para dar seguimento a esse levantamento, da forma como se pretendia, que envolvia a visitação às unidades e a pertinente verificação dos dados previamente coletados pelo questionário. Todavia é uma referência que permitiria o encaminhamento de um programa de ações para a área de vídeo na USP.

Conforme já comentamos, a partir de 1997, as atividades do UNIVÍDEO sofreram um esvaziamento. O cadastramento do acervo de vídeos e filmes da USP foi interrompido, os cursos cessaram e o próprio Conselho de Planejamento se desfez. O entusiasmo inicial esgotou-se por falta de apoio e de resultados mais significativos.

Porém, em 1999, o UNIVÍDEO, ainda com a Coordenação Acadêmica da Profa. Marília Franco e tendo em vista a finalização das atividades de pesquisa deste mestrando, considerou pertinente realizar uma atualização do Diagnóstico de 96 e proceder a uma comparação dos dados. Foi mantido o mesmo questionário, de autopreenchimento,. o encaminhamento do material e seu acompanhamento ficou a cargo de um aluno de graduação, bolsista da COSEAS/USP. A proposta de obter registros de dois momentos distintos, um em 96 o outro em 99, era estimulante pela possibilidade de verificarmos as mudanças ocorridas e as tendências que seriam apontadas. Mas a sua validade exigiria um rigoroso controle dos procedimentos de coleta dos dados e da sua análise, sob o risco, simplesmente, de compararmos dados supostamente referentes a uma mesma questão e que, de fato, estão relacionados a interpretações distintas de quem respondeu aos questionários nos dois momentos.

A atualização do Diagnóstico enfocou o mesmo universo de 34 Unidades universitárias, que foram aquelas que haviam respondido ao questionário em 96. Obteve-se 25 respostas sendo 20 de Unidades de Ensino e Pesquisa e 5 de Extensão e complementares $^{77}$. Como já foi mencionado, o encaminhamento e o processamento do material ficou sob responsabilidade de um aluno da graduação, que não é da área de Comunicações e também não é o mesmo que cuidou do primeiro levantamento. Desde o

\footnotetext{
${ }^{77}$ As Unidades pesquisadas foram: Escolas - de Educação Física, de Enfermagem, de Enfermagem de Ribeirão Preto, de Engenharia de São Carlos, Superior de Agricultura “Luiz de Queiroz" de Piracicaba; Institutos - Astronômico e Geofísico, de Estudos Avançados, de Estudos Brasileiros, de Física, de Física de São Carlos, de Química, Oceanográfico, de Psicologia, CEBIMAR de São Sebastião; Faculdades - de Educação, de Ciências Farmacêuticas, de Ciências Farmacêuticas de Ribeirão Preto, de Filosofia, Letras e Ciências Humanas, de Odontologia, de Zootecnia e Engenharia de Alimentos; outras Unidades - Museu de Arte Contemporânea, Museu de Arqueologia e Etnologia, Museu Paulista, CEPEUSP, SIBI.
} 
início, em 96, havíamos colocado a necessidade de um apoio financeiro para que essa atividade fosse realizada por uma pessoa capacitada, especializada nas questões de equipamentos e nos problemas de produção de vídeos no ambiente acadêmico, porém não houve respostas aos nossos apelos. O único apoio obtido foi uma bolsa trabalho da COSEAS, para o aluno de graduação. Dessa forma a atualização do Diagnóstico deverá ainda passar por uma apurada análise dos dados coletados em 99 e, posteriormente, verificar-se as possibilidades de comparação com o material levantado em 96.

O projeto UNIVÍDEO não configurou-se como uma pesquisa acadêmica, portanto não poderia buscar apoio financeiro das agências de financiamento da atividade científica. Seu sucesso sempre dependeu do apoio da própria Universidade e, inicialmente, suas realizações foram fruto da dedicação do grupo que participava de seu Conselho de Planejamento. Na falta dos recursos financeiros necessários para consolidar o trabalho de uma equipe não foi possível o desenvolvimento sistemático e o aprimoramento das propostas inicialmente colocadas. 


\section{4 - Fundo de Cultura e Extensão}

Em outubro de 1995, a Pró-Reitoria de Cultura e Extensão da USP cria o FCEx Fundo de Cultura e Extensão Universitária, com a finalidade de fomentar as atividades

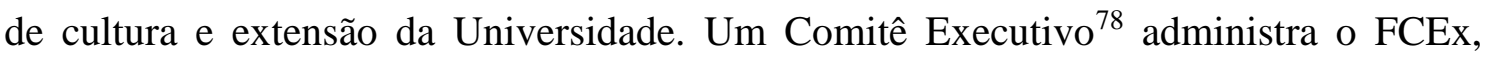
analisando e deliberando a concessão de recursos aos projetos apresentados pelas unidades da USP, por professores ou por alunos. As diretrizes para utilização de recursos do Fundo de Cultura enfatizam a necessidade dos projetos estarem associados a atividades de ensino e pesquisa. São priorizadas as seguintes áreas:

a) inclusão e coesão social: metodologias e iniciativas que enfrentem as causas da exclusão social,

b) cooperação com o ensino de $1^{\circ}$ e de $2^{\circ}$ graus: metodologias e experiências visando a melhoria da qualidade do ensino.

c) obtenção de recursos externos para iniciativas artísticas, culturais e de extensão universitária: recursos que possibilitem a elaboração de projetos artísticos e culturais. $^{79}$

Tais diretrizes permitem a apresentação de projetos de produção de vídeos. Um documentário pode abordar problemas de inclusão social estimulando o debate da questão, pode também ser utilizado em atividades de ensino ou pode ser um projeto artístico e cultural. A criação do FCEx abriu a possibilidade de resolver um dos problemas mais críticos da realização de vídeo na universidade que é, justamente, a obtenção de verbas para as despesas da produção ${ }^{80}$. Segundo as diretrizes aprovadas pelo Conselho de Cultura e Extensão, cada montante liberado pelo FCEx terá um teto máximo de $\mathrm{R} \$ 20.000,00$. Especificamente para a área de audiovisual, há uma orientação do Fundo para que sejam apresentados somente projetos de elaboração de roteiro e não de toda a sua produção, pois é considerado inviável o seu custeio de

\footnotetext{
${ }^{78}$ Esse comitê é composto pelo Pró-Reitor de Cultura e Extensão Universitária da USP, pelo coordenador da Câmara de Cultura, pelo Coordenador da Câmara de Extensão e por um representante do corpo discente.

${ }^{79}$ Conforme consta na Resolução 4206/95, 4259/96, da RUSP, e normas aprovadas pelo Conselho de Cultura e Extensão Universitária, de 12/03/98.

${ }^{80} \mathrm{O}$ problema dos custos de produção serão comentados no capítulo 5.
} 
integral. Desta forma, o FCEx poderá apoiar financeiramente a etapa de pré-produção de um documentário, que envolve pesquisa de conteúdo, levantamento de locações, entrevistas para seleção de depoentes e o planejamento da produção. Em alguns casos, de documentários fora de São Paulo, as despesas de pré-produção serão significativas. Foi com o apoio do FCEx, em 1998, que iniciamos, no Laboratório de Vídeo da FAU, a produção de um documentário na região de Cananéia. ${ }^{81}$

Vale a pena comentar que há uma contradição nestas normas, pois o recurso máximo, de $\mathrm{R} \$ 20.000,00$, é suficiente para custear toda uma produção, desde que a Unidade de origem do projeto já disponha de equipamentos profissionais e/ou de experiência de produção de vídeos. Esse é o caso de algumas Unidades da USP como a ECA, a FAU, a Faculdade de Educação, o Departamento de Antropologia da FFLCH, o Hospital Universitário. Limita-se o apoio a apenas uma etapa da produção, mas o valor possível de ser concedido atende, num orçamento dimensionado razoavelmente, à realização completa de um documentário. Como veremos a seguir, um outro programa de apoio, o SIAE, parte de uma referência inversa de valores, propõe o apoio integral à produção, mas com verbas geralmente insuficientes.

\footnotetext{
${ }^{81}$ O projeto apresentado ao FCEx era mais ousado e propunha a preparação de dois documentários sobre os caminhos da ocupação do território nacional, envolvendo viagens a diversos estados, de norte a sul do Brasil. O recurso concedido não foi suficiente (foi liberado $15 \%$ do valor solicitado) e fizemos uma drástica adaptação do projeto, adequando-o às nossas possibilidades reais e preservando a essência da temática.
} 
3.5 - SIAE - Sistema Integrado de Apoio ao Ensino das Pró-Reitorias de Graduação e de Pós-Graduação

A iniciativa recente, que mais repercutiu na área do audiovisual da USP, estimulando a produção de vídeos, foi a criação do Programa de Incentivo à Produção de Materiais Didáticos, pelas Pró-Reitorias de Graduação e de Pós-graduação, em março de 1997. Conhecido como SIAE - Sistema Integrado de Apoio ao Ensino, tem por objetivo apoiar projetos que visem à melhoria do ensino de graduação e de pósgraduação através da utilização de recursos didáticos que explorem novas tecnologias e que facilitem a divulgação interna e externa do conhecimento instalado na USP. Abrangendo diversas mídias, internet, CD-ROM, vídeo, banco de dados digitalizados, o SIAE liberou recursos diretamente para a produção desses materiais.

Na primeira edição do Programa, em 1997, dos 196 projetos inscritos 52 foram aprovados, sendo 28 da área de Ciências Biológicas, 14 da área de Ciências Exatas e 10 da área de Humanas. A distribuição das tecnologias escolhidas pelos projetos foi a seguinte: $37 \%$ optaram por desenvolver Web sites, 33\% produziram CD-ROM, 22\% produziram vídeos, 4\% internet/CD-ROM, 2\% internet/CD-ROM/Vídeo e 2\% texto/disquete. O site do SIAE indica os resultados alcançados (www.usp.br/siae).

O projeto realizado pelo Laboratório de Vídeo da FAU com recursos do SIAE 97, o documentário "Taipa de mão, casa de caboclo", obteve ótima receptividade junto ao público da USP e também o externo. Foi premiado como melhor vídeo universitário na II Mostra de Vídeo do Museu da Imagem e do Som, em outubro de 98 e, recebeu Menção Honrosa no $11^{\text {th }}$ International Housing and Planning Film/Video Competition, Lisboa, Portugal, em setembro de 98.

Esse projeto "Taipa de mão, casa de caboclo" já existia desde 1994, a partir de uma pesquisa sobre arquitetura vernácula na região do Alto Ribeira, mas não havia recursos para a sua produção. Todas as gravações eram no Vale do Rio Ribeira implicando em custos de transporte, alimentação e estadia da equipe de vídeo e só a partir do Programa SIAE é que foi possível a sua execução. 
A segunda edição do Programa, de 1998, ainda em andamento, aprovou 66 projetos (de 96 apresentados) sendo, 31 da área de Ciências Biológicas, 23 da área de Exatas e 12 de Ciências Humanas.

Alguns problemas, porém se colocam: primeiro, o SIAE limita o orçamento de um projeto a $R \$ 5.000,00$. Com esse valor a realização de um vídeo com boa qualidade técnica só é viável para as unidades da USP que já disponham de equipamentos de gravação e de edição de tipo profissional e de técnicos especializados em produção de vídeo. Nesta condição e com um projeto de pequena escala, que não demande muitas gravações, o recurso obtido junto ao SIAE poderá viabilizar a produção. As unidades que não dispõem de equipamentos e funcionários capacitados para a realização de vídeo dependerão de colaborações, pois o valor total de uma produção, incluindo a locação de equipamentos e os serviços de técnicos especializados, ultrapassa muito o limite estabelecido.

Outro problema apontado por participantes do Programa, foram as dificuldades próprias da produção audiovisual, seja de um CD-ROM, seja de um vídeo. Os docentes e/ou pesquisadores não estão habituados a produzirem materiais nas mídias eletrônicas e desconhecem os aspectos técnicos envolvidos e a elaboração de roteiros. Por ocasião do encerramento do SIAE 97, vários depoimentos de professores apontaram para a necessidade de orientação técnica no desenvolvimento da produção. É necessário oferecer um apoio aos projetos, além do financeiro, e nem a USP, nem o SIAE, possuem uma infra-estrutura que viabilize tal apoio.

A ECA, naturalmente, é solicitada à colaboração e constantemente o faz, porém suas próprias finalidades, de Ensino e de Pesquisa, impõem limitações operacionais e não há condições para atender toda a demanda apresentada. No projeto SIAE 97, a ECA apoiou as produções do Instituto de Psicologia, do Instituto de Física e da Faculdade de Odontologia.

Nesse sentido, cabe à USP verificar qual é a infra-estrutura necessária para amparar o investimento que está sendo feito nessa produção. 
Isto delineia a absoluta necessidade de articulação de condições para a produção do audiovisual e suas extensões - CD-ROM e sites - conforme está expresso no projeto inicial do UNIVÍDEO.

\section{6 - Fundação de Amparo à Pesquisa do Estado de São Paulo}

A FAPESP - Fundação de Amparo à Pesquisa do Estado de São Paulo, além da sua tradicional excelência no apoio à pesquisa científica, tem desempenhado um papel significativo no auxílio financeiro aos projetos que incluem os recursos do vídeo nas atividades das pesquisas propostas. $\mathrm{O}$ caso dos projetos desenvolvidos no Laboratório de Vídeo da FAU/USP é representativo desse apoio. No decorrer da última década, trabalhamos junto a pesquisadores, documentando pesquisas e editando programas para a difusão dessas pesquisas e, para isso, recorremos à FAPESP, na modalidade de auxílio individual, solicitando verbas para o custeio de despesas de produção da documentação e da edição (fitas de vídeo, transporte, refeições, materiais técnicos, serviços especializados de terceiros).

Na modalidade de apoio à infra-estrutura de equipamentos multi-usuários, por atendermos a diversos pesquisadores da FAU, realizamos uma atualização de tecnologia audiovisual que dificilmente seria possível com recursos da faculdade e, no apoio à infra-estrutura geral, obtivemos verba para criar novas instalações para o Laboratório de Vídeo, totalmente planejadas e adequadas tecnicamente às finalidades do setor. Sem dúvida, o fato deste laboratório manter sistematicamente um trabalho integrado às pesquisas desenvolvidas na FAU, sustentou nossas solicitações e a FAPESP continua apoiando esse trabalho.

A FAPESP atende também a propostas de publicações de resultados de pesquisas, pois a difusão do conhecimento científico e tecnológico é uma de suas atribuições. O conceito de publicação poderia ser flexibilizado e incluir a edição de outras mídias que cumprem, tanto quanto um livro, o papel de difusão. A difusão, inclusive, não é simplesmente resolvida com a impressão de um material, envolve ainda a distribuição, a divulgação e o acesso ao material. 
No final de 1999, a FAPESP implantou uma nova modalidade de apoio denominada "Programa José Reis de Incentivo ao Jornalismo Científico":

"De modo geral, a sociedade brasileira não demonstra um interesse significativo pelo curso e pelos produtos da ciência. Particularmente notável é o nível de desconhecimento sobre as atividades de pesquisa desenvolvidas no Brasil. Isso se deve, em grande parte, à carência de jornalistas com motivação específica e formação adequada no campo do jornalismo científico

..., estudo recentemente realizado pela National Science Foundation, publicado na revista Nature, vol. 394, p. 107, atribui a visão majoritariamente favorável da opinião pública americana a respeito do impacto social das atividades científicas e tecnológicas à intensa cobertura jornalística de que tais atividades são objeto nos diferentes meios de comunicação.

O presente programa tem por objetivo contribuir para a superação dessa carência, estimulando a formação de profissionais especializados no campo do jornalismo científico...,

Trata-se de programa de Bolsas de Jornalismo Científico, destinadas a apoiar a execução de propostas de pesquisa jornalística, que resultem na produção de documentos jornalísticos de divulgação, em veículos de comunicação de qualquer natureza - jornais, revistas, rádio, televisão, mídia eletrônica, etc. - de um ou mais projetos ou programas de pesquisa, paralelamente ao cumprimento de um programa específico de estudos. Esse programa deve incluir a realização de um Curso de Introdução ao Jornalismo Científico. Um dos objetivos específicos do programa é precisamente estimular a criação de tais cursos, dentro e fora do âmbito acadêmico, eventualmente com o patrocínio de empresas de comunicação." 82

Tal iniciativa é extremamente louvável e reflete a preocupação de implantar uma política de integração das ciências no cotidiano da sociedade. É interessante destacar que o programa da FAPESP articula-se com ações pertinentes à universidade, a criação de cursos de jornalismo científico (ou a volta deles, como os realizados pelo Núcleo José Reis) e, também, a sua vinculação a um ou mais projetos de pesquisa.

${ }^{82}$ FAPESP, "Programa José Reis de Incentivo ao Jornalismo Científico", disponível via internet, www.fapesp.br março de 2000. 


\section{7 - Educação Continuada a Distância}

Em 1995 a USP inicia um debate sobre a Educação a Distância, considerando a importância do tema na sociedade e na comunidade acadêmica. O Conselho de Cultura e Extensão da Pró-Reitoria de Cultura institui um grupo de trabalho ${ }^{83}$ para analisar a questão e verificar a experiência da USP na área. Em outubro de 95 é apresentado um seminário e um documento contendo propostas e os dados do levantamento realizado. Ali considerava-se,

“A inserção desse tema nas prioridades da USP é necessária e oportuna. Sua necessidade decorre da visão de universidade conectada com a sociedade e, portanto, sensível às suas demandas por conhecimento e inovação.

Sua oportunidade advém, por um lado, de fatores internos - em especial a germinação de diversas iniciativas de $E c a D$ na Usp, adiante expostas. Diversos agentes externos também concorrem, entre os quais se menciona: a recente sanção da lei 8.977/95, que dispõe sobre o serviço de TV a cabo; a integração da USP, em setembro p.p., ao Consórcio interuniversitário de Educação Continuada à Distância (que conta com cerca de meia centena de universidades); a entrada no mercado sul-americano de várias universidades estrangeiras pela via da $E c a D$; e, a solicitação de que a nossa Universidade participe de forma cada vez mais ativa de parcerias nacionais e internacionais." 84

Conforme tais considerações, entende-se que a administração da USP é levada a posicionar-se diante da questão da sua conexão à sociedade, através da Educação a Distância, pelo fato de que várias de suas unidades já estavam desenvolvendo atividades dessa natureza e também, com o espaço então criado pelas novas tecnologias de telecomunicações, acompanhar a movimentação das outras instituições de ensino superior na ocupação desse espaço. De fato, a USP, na sua grandeza e complexidade, comporta iniciativas que muitas vezes se adiantam à existência de programas articulados e planejados por sua administração central, criando uma relação dinâmica

\footnotetext{
${ }^{83}$ Participaram desse grupo os professores: Profa. Dra. Ana Luiza Vieira de Mattos, da Faculdade de Educação; Prof. Dr. Angelo Pedro Piovesan Neto e Prof. Dr. Luiz Fernando Santoro; da Escola de Comunicações e Artes; Prof. Dr. Antonio Helio Guerra Vieira, da Escola Politécnica; Profa. Dra. Diva Benevides Pinho, da Faculdade de Economia e Administração e pela Pró-Reitoria de Cultura e Extensão; Prof. Dr. Franco Levi, do Instituto de Geociências; Profa. Dra. Lygia Busch Iversson, da Faculdade de Saúde Pública e da Câmara de Extensão Universitária; Profa. Dra. Maria Amélia Azevedo, do Instituto de Psicologia; prof. Dr. Guilherme Ary Plonsky, da CECAE e o Prof. Dr. Jacques Marcovitch, Pró-Reitor de Cultura e Extensão.

${ }^{84}$ Educação Continuada à Distância na Universidade de São Paulo, CECAE/USP, 1995.
} 
entre as partes, ora a Reitoria se antecipa e propõe novas metas às unidades, ora seus professores e seus departamentos iniciam novos programas de ação. Assim, o referido documento propõe como política que, "A USP considera a Educação Continuada a Distância um meio relevante para a consecução de seus objetivos no campo da extensão universitária. A EcaD constitui uma continuidade das atividades de extensão."

É proposta, como diretriz para a política de EcaD na USP, estabelecer a Rede de Educação Continuada a Distância, visando reunir e facilitar a comunicação entre os responsáveis por tais iniciativas. Entre as ações indicadas para a Rede estão:

- promover o treinamento de pessoal docente e técnico requerido para a produção e realização de cursos de EcaD;

- promover a eficiência na utilização das competências profissionais e dos recursos materiais na Universidade, articulando e incentivando o intercâmbio de experiências;

- promover o compartilhamento de equipamentos e materiais, assim como a divulgação de informações sobre fornecedores de serviços, supridores de materiais e entidades financiadoras;

- organizar uma base de dados para consolidar e veicular informações técnicas e gerenciais sobre planejamento, pesquisa. gestão e avaliação de programas de EcaD.

Esse documento, aprovado no Conselho de Cultura e Extensão, em outubro de 95, localiza no UNIVÍDEO, várias das competências e recursos para atender à Rede de Educação a Distância, note-se a questão da capacitação técnica, da centralização e difusão de informações, do levantamento da base técnica de produção. Ora, considerando, como já mencionado anteriormente, que o UNIVÍDEO não obteve recursos para desenvolver plenamente suas atividades, que estas contemplavam substancialmente os propósitos da Rede EcaD, que a própria Rede não foi implantada e que a USP não dispõe nem mesmo de um site que informe quais as atividades de EcaD em andamento na USP, pode-se concluir que este é mais um caso da dificuldade desta 
Universidade em desenvolver programas articulados de uso das novas tecnologias da comunicação.

Em abril 1998, já com a nova LDB, o Ministério da Educação e Cultura normatizou o credenciamento de instituições para cursos a distância, inclusive no nível de graduação. Atualmente várias instituições públicas e privadas já tem programas consolidados de Educação a Distância. A Universidade de Brasília iniciou, em 98, um projeto piloto de ensino a distância que evoluiu para um consórcio de universidades federais e estaduais de Goiás, Mato Grosso e Mato Grosso do Sul. Envolvendo docentes dessas instituições, a Universidade Virtual do Centro Oeste brasileiro- Univir-CO, oferece cursos de graduação e de extensão e está acessível na internet (www.universidadevirtual.br).

A USP tem realizado algumas atividades de EcaD, porém continuam como ações isoladas das Unidades. O CDCC de São Carlos, a Escola Politécnica, o Instituto de Psicologia, a ESALQ tem programas que carecem de apoio, em geral realizados devido ao esforço e à dedicação dos docentes e técnicos das Unidades.

O CCE - Centro de Computação Eletrônica, investiu na montagem de um espaço preparado especialmente para atividades de Ensino, Pesquisa e Extensão, com recursos de informática e de vídeoconferência - o USP Oficina - o que é extremamente louvável, principalmente por ser de uma unidade de apoio a toda Universidade. ${ }^{85}$ Como indicava o documento supra mencionado, analisado e aprovado no CoCEX, uma das ações imediatas seria:

- propor uma política de instalação, adequação, aquisição ou locação de base física compatível,

- identificar e facilitar a obtenção de recursos extra-orçamentários em agências de fomento para iniciativas conjuntas.

Esse tem sido um ponto fundamental do fracasso de inúmeras tentativas e de experiências de utilização de recursos audiovisuais e de outras tecnologias da

${ }^{85}$ O CCE está em vias de inaugurar também um estúdio multimeios, integrado a equipamentos de edição, de computação gráfica, voltado para apoiar iniciativas na área da produção de vídeos. 
comunicação na USP, a falta de agilidade para definir estratégias de financiamento dos projetos.

Mas o aspecto principal e que antecede as questões práticas, é sobre a concepção de ensino e do uso das tecnologias da comunicação, conforme apontado pelo Prof. Claudio Zaki Dib ${ }^{86}$, especialista em Tecnologia Educacional,

"nós precisamos manter a universidade formal, eu não vou acabar com isso, ao lado disso nós devemos desenvolver a universidade virtual com a incorporação dessas tecnologias, a informática, as telecomunicações, gradualmente, por ex., a videoconferência, se eu tentar colocar alguma coisa certamente isso não vai ser bem recebido, é difícil, é muito conservadora a USP. Eu acho que a universidade devia ir incorporando mais rapidamente, promovendo o acesso a universidade a quem não pode vir a universidade todos os dias, através de programas de ensino à distância, com a criação gradual de programas ..., isso nós poderíamos fazer, como as universidades latino-americanas já fazem isso, ... as universidades mais variadas, na Argentina, no México, o Instituto Tecnológico de Monterey, tem programas à distância, via satélite, que oferecem para América Latina, aqui aFaculdade Anhembi-Morumbi tem um setor de educação à distância, que nós não temos na USP, ...nós ainda estamos discutindo se devemos sair da carroça ir para o carro. Eu fico constrangido ao ouvir 'é importante se usar a videoconferência', eles já usam a videoconferência direto, a questão é que videoconferência é um meio, serve para certos objetivos, não vamos tentar transformar tudo em videoconferência..., ...o presidente da Siemens me falou 'o senhor tem toda a razão, a videoconferência serve para algumas coisas ...', mas vende-se a videoconferência, por quê? Porque nós não sabemos exatamente como é que ocorre um processo de aprendizagem, e no momento em que nós entendermos, nós vamos saber até que ponto o uso do satélite interessa, internet interessa, intranet, videoconferência, multimídia, os vídeos, os áudios, o texto, o papel do professor, a dinâmica de grupo, o processo interativo. Quer dizer, nós somos muito ignorantes nesse sentido, nós somos muito enrolados ..., Dentro da universidade os procedimentos passam a ser procedimentos que não condizem, não correspondem, àquilo que é necessário, todo mundo centralizado no professor, no sistema educativo, pouco centralizado no aluno,

\footnotetext{
${ }^{86}$ Depoimento coletado pelo autor em outubro de 1999.
} 
na sociedade. Os objetivos nem sempre atendem aos objetivos nem de alunos, nem da sociedade, nós vamos ensinar uma física ao professor de $2^{\circ}$ grau, que é uma física do século passado, nós não atualizamos, os procedimentos são os mesmos de 100, 200, 300 anos atrás.

Até aqui tem sido o domínio da informação, daqui por diante tem que ser o domínio de habilidades superiores, o conhecimento já não é tão importante quanto as habilidades, ... precisa saber buscar a informação, saber pegar 40 mil na internet e tirar aquelas 20 que vão ajudar você a resolver aquele problema que você equacionou, ... é uma mudança de paradigma, você precisa desenvolver habilidades específicas no seu aluno e ele vai buscar a informação, então é outra postura e a nossa universidade não está absolutamente preparada para isso. É preciso uma mudança de paradigma, sair do velho modelo para novos modelos, um modelo centrado no consumidor, que é o aluno e a sociedade, não é fazer um super mercado, essa mudança de paradigma é fundamental." 


\section{8 - TV USP - CCS}

Para finalizar este levantamento de casos apresento a seguir um resumo do histórico e comentários, sobre a TV USP.

Em outubro de 1996 ocorreu o $1^{\circ}$ Encontro dos Canais de Acesso Público do Estado de São Paulo promovido pela ex-deputada Irma Passoni ${ }^{87}$. O Encontro visava discutir a organização das formas de participação das entidades interessadas em utilizar os canais de serviços públicos, pelo sistema de TV a cabo, garantidos pela Constituição. São 4 esses canais: educativo, comunitário, legislativo e universitário. Segundo a Constituição, as concessionárias de serviço de televisão a cabo, nas suas várias modalidades de transmissão, são obrigadas a reservar canais para fins de utilidade pública e em todo o município onde houver uma universidade deverá ser disponibilizado um canal universitário.

São Paulo tem várias universidades e a forma adotada para o compartilhamento do respectivo canal foi a criação de um consórcio das instituições interessadas. Foram nove as universidades que assumiram o compromisso de implantar o Canal Universitário: Universidade Bandeirante, Universidade Cruzeiro do Sul, Universidade Federal de São Paulo, Universidade Mackenzie, Universidade Paulista, Universidade Santo Amaro, Universidade São Judas Tadeu, Universidade de São Paulo, Pontifícia Universidade Católica de São Paulo. Foi firmado um convênio de cooperação mútua e definido que o início das transmissões se daria a partir das instalações da TV-PUC, pioneira na produção de programação para TV a cabo e que já estava conectada à rede de transmissão.

Na USP, a CCS - Coordenadoria de Comunicação Social, solicitou à Profa. Dra. Marília Franco a elaboração de um projeto, do qual participei como colaborador, que apontasse as necessidades e propostas da futura TV USP. Resgato aqui duas considerações apresentadas junto a uma primeira versão do projeto TV USP, de junho de 97, que abordam questões pertinentes a esta dissertação:

\footnotetext{
${ }^{87}$ Irma Passoni foi encarregada pelo Ministério das Comunicações de desenvolver a regulamentação dos canais dedicados a serviços públicos no sistema de tv a cabo.
} 
A primeira consideração leva em conta o fato de que a produção de televisão e as atividades acadêmicas são muito diferentes no que diz respeito à ritmo e aprofundamento. A primeira está baseada em rapidez e superficialidade, enquanto a academia orienta-se por aprofundar, no ritmo necessário, o desenvolvimento de todas as suas atividades.

Isto chama a atenção para que uma TV que emane do ambiente acadêmico construa características específicas de abordar seu objeto, o que evidencia a necessidade de desenvolvermos um projeto próprio, híbrido das duas naturezas, quase opostas, que lhe servem de parâmetro.

A segunda consideração refere-se à estrutura jurídico-administrativa-financeira que possa viabilizar um projeto que precisa ter ritmo e agilidade próprias, que não se encaixam na tradição administrativa da academia nem do serviço público. Mesmo não tendo os compromissos de produção e emissão de uma TV comercial, a TV USP precisará, sobretudo no seu processo de implantação, de agilidade para constituir-se como estrutura especial.

O Canal Universitário entrou em funcionamento em novembro de 1997 e a TV USP surge, no ambiente acadêmico da USP, como um novo vetor para a área da produção audiovisual. Sua existência é um estímulo à realização de vídeos, pois sempre há a possibilidade de exibição no Canal Universitário, o que é uma boa resposta à questão de como alcançar um público maior, não só da comunidade acadêmica, mas também extra universitário. Outro aspecto significativo é que, mesmo com as especificidades de ser uma TV com programação diária, com seu ritmo próprio e com programação voltada para um público definido a priori (ainda não existem aferições de audiência e de perfis de público na TV a cabo), a sua qualidade técnica e de tipos de programas vão tornar-se uma referência para outros produtores de vídeo da Universidade.

Perante o público que a assiste a TV USP é a vitrine da produção audiovisual desta Universidade. Infelizmente, até o momento, a própria USP ainda não tem a infraestrutura de cabeamento para apreciar a sua TV o que muito significaria no sentido de integrá-la efetivamente ao cotidiano universitário. 


\section{4 - Relatos pessoais}

O desenvolvimento da pesquisa sobre as experiências de produção audiovisual na USP contou com a colaboração de várias pessoas, algumas das quais concederam-me entrevistas. Esse material, com algumas partes já inseridas no decorrer deste relato, contém uma riqueza de comentários dos propósitos pessoais e dos contextos do trabalho audiovisual na Universidade, que considero pertinente apresentar três deles mais extensamente. Esses depoimentos refletem posturas e propostas distintas e não me parece correto fragmentá-los, são relatos de experiências de vida.

\section{1 - Mario Guidi}

O Prof. Dr. Mário Arturo Alberto Guidi, do Instituto de Psicologia, realizou sua tese de doutorado baseada inteiramente no registro cinematográfico de seu objeto de estudo - a etologia da formiga saúva. A etapa seguinte, de Livre Docência, foi realizada no CTR - Departamento de Cinema, Rádio e Televisão da ECA, versando sobre a história instrumental da cinematografia. Em seu percurso de mais de trinta anos de universidade, colaborou com vários pesquisadores incentivando o uso do cinema e do vídeo principalmente para a produção da imagem científica.

"Quando eu estive no CRPE - Centro Regional de Pesquisas Educacionais, por volta de 1955, eu trabalhei lá ainda como aluno, como auxiliar de pesquisa, eu estava no setor de estatística, mas eu sempre me interessei muito pela parte de fotografia, cinematografia, ... e existia um convênio com os EUA, com base no famoso 'Ponto 4'. Umas dessas atividades de ajuda norte americana à América latina, em função desse acordo, desse 'Ponto 4', no CRPE foi montado um laboratório, na verdade um estúdio de cinematografia em $16 \mathrm{~mm}$, profissional, semi profissional, tanto quanto se possa diferenciar o 16 do 35, como na verdade em termos de atividades científicas, educativas, o $16 \mathrm{~mm}$ sempre foi a bitola utilizada, podemos até falar realmente numa estrutura profissional mesmo, que incluiu a vinda de técnicos norte-americanos aqui para o Brasil, para a produção de material fílmico, em $16 \mathrm{~mm}$, para fins educativos. Eu cheguei a ver alguma dessas produções e eram de qualidade técnica indiscutível, 
realmente aquela coisa de americano: é prá fazer, é prá fazer. Então tinha moviola, câmera, equipamento de iluminação, tudo, um material de primeira linha.

Esse meu período no CRPE - Centro Regional de Pesquisas Educacionais foi relativamente curto, coisa de pouco mais de um semestre, apesar das minhas ligações permanecerem porque eu estava muito ligado ao grupo de professores que trabalhavam lá no Departamento de Estatística, naquela ocasião, mas efetivamente como trabalho regular mesmo eu tenho impressão que foi coisa que durou menos de um ano. E aí eu recebi o convite p/ trabalhar numa empresa cinematográfica, que na época era a empresa cinematográfica que tinha o maior volume na produção de filmes de propaganda para televisão. Antes da época do vídeo, toda propaganda da televisão, ou era ao vivo ou era em película, que depois era inserida na programação por meio de telecinagem, o telecine. .Então essa empresa que trabalhava nesse ramo, a J.Filmes, o diretor me convidou para trabalhar lá e essa empresa praticamente era constituída de elementos todos que tinham vindo para a famosa Vera Cruz. Eram todos técnicos, todo um pessoal que tinha vindo de fora: da França, da Inglaterra, até dos EUA, da Itália, quando se tentou a famosa "Cinecittá" brasileira, lá em São Bernardo do Campo.

Então eu adquiri, realmente, um certo conhecimento técnico mesmo de cinematografia que eu não tinha, eu tinha conhecimentos razoáveis de fotografia, mas de cinematografia praticamente eu não tinha nada. Aprendi lá com técnicos realmente muito bons, com profissionais muito bons, sejam os estrangeiros sejam profissionais que já tinham sido treinados na própria Vera Cruz.

Quando eu fui contratado pela USP, em 66, a minha idéia era realmente tentar utilizar um pouco mais a cinematografia, o filme como um instrumento de registro de dados científicos. A minha preocupação não era tanto voltada para o chamado filme educativo, mas para o filme científico strito-senso, quer dizer é o uso do registro da imagem como uma forma de registro de dados para o pesquisador, que aliás é como nasce o cinema ,né? Através do Etiènne-Jules Marey, a preocupação dele era usar o cinema como uma forma de registrar aquilo que ele estudava, que era o movimento do homem, dos animais, dos cavalos. O cinema na verdade não nasce espetáculo, o cinema nasce ciência, ele nasce científico. Ele é uma forma de registro de dados científicos. Posteriormente ele é aproveitado, naquilo que ele tem de sensacional, de novo, de inédito, que é a síntese do movimento, a reconstrução do movimento.

A minha preocupação inicial, na verdade, inclusive por conhecer exatamente a complexidade de uma produção cinematográfica, é que eu sabia ser praticamente 
inviável montar uma produtora de filmes educativos, mesmo porque existe toda uma filosofia por trás dessa minha postura. A idéia do que é o filme, do que é a imagem, o recurso audiovisual, possa vamos dizer, ser utilizado amplamente na educação sempre foi uma idéia, em alguns aspectos, um pouco utópica, ou um pouco otimista. Isso acabou sendo demonstrado em vários países quando se tentou, inclusive no próprio Brasil, na época do Estado Novo, na época do Getúlio, com o INCE: Instituto Nacional do Cinema Educativo, aonde a idéia era que em cada escola tivesse um projetor de cinema e que se produziria filmes educativos, educacionais, que então a educação daria um salto, mas aqui no Brasil, como em outros lugares, se verificou que não é tão simples assim a utilização ampla do cinema ou mesmo do vídeo num sistema educativo.

Eu acho que aí a gente pode usar aquele ditado adaptado, eu acho que o vídeo na educação, o cinema na educação, pode ser um bom servo, mas é um mau senhor. Se você emposta muito a tua proposta educacional, ou educativa, em torno do modelo visual, eu acho que as conseqüências podem ser muito pouco encorajadoras, precisa um pouco mais. Ou talvez precise de uma forma que nós ainda não atingimos, principalmente no que diz respeito aos processos interativos entre a mensagem e o receptor. Por mais dinâmico que seja o processo que você use na produção, na roteirização de um filme, de um vídeo, você continua deixando o espectador, neste caso o espectador - aluno, numa posição que é extremamente passiva diante do material que ele está vendo. A possibilidade de interação do aprendiz com o mestre, aí no caso a tela de cinema ou de vídeo, é praticamente muito pequena. Claro que existem todas as experiências que nós já conhecemos, dos sistemas interativos, mas eu acho que ainda estamos um pouco longe do modelo adequado.

Então minha idéia nunca foi realmente tentar fazer alguma coisa no sentido de um cinema educativo na psicologia, mas fazer cinema científico no seu conceito mais puro, mais restrito, quer dizer, se nós trabalhamos com observação de comportamento, como de fato se trabalhava e se trabalha até hoje, se nós observamos esse comportamento e o anotamos através de sistemas tradicionais, como caderninho de notas, um gravador, aonde transpor aquilo que nós estamos vendo, porque não fazer isso diretamente numa película cinematográfica?

Com isso eu consegui que fosse comprado um equipamento $16 \mathrm{~mm}$, câmera e um projetor de cinema e eu comecei a trabalhar registrando o arquivo que naquela época era, vamos dizer, dos núcleos de pesquisa mais importante na área de etologia, de psicologia comparada, como se dizia então, que era a pesquisa sobre saúva, que era 
liderada pelo Prof. Valter Hugo de Andrade Cunha que dispunha inclusive de um formigueiro, de um sauveiro de laboratório, um sauveiro artificial e que todo ano, por ocasião dos fenômenos da revoada dos formigueiros, ia a campo junto com os alunos. Inicialmente eu fiz um trabalho de registro fotográfico, e posteriormente eu comecei a utilizar a câmera cinematográfica. Isso durou um período bastante longo, mas o período mais intenso da minha atividade foi entre 67 e 73 quando eu utilizei o material que eu tinha coletado, filmado para elaborar a minha tese de doutoramento.

Agora, as dificuldades realmente sempre foram muito grandes, principalmente no que diz respeito a custo. O custeio do material, dos procedimentos cinematográficos, eram muito altos, mesmo excluindo toda parte de uma produção cinematográfica, tal como ela é entendida, no sentido assim de produção mesmo de filme. Mesmo para a finalidade pura e simples de registros de dados científicos, ainda assim o custo da película, o laboratório, quer dizer, eram obstáculos muito grandes e dificilmente conseguia o dinheiro necessário para isto.

Então eu passei boa parte da minha carreira, na Psicologia, construindo equipamentos, procurando soluções técnicas, instrumentais, para problemas de pesquisa, para situações particulares. Então eu tive uma certa facilidade nesse sentido, quer dizer, eu estava habituado a enfrentar esse tipo de problema. Eu construía suportes especiais pra utilizar a câmera, eu mandei fazer lentes de aproximação que depois eu adaptei na própria objetiva da câmera. Não é que eu conseguisse solucionar todos os problemas técnicos, mas eles não me pesaram tanto e eram desafios para alguém que estava mais ou menos preparado para enfrentá-los, porque, paralelamente a esta área de fotografia e cinema no Departamento, eu era responsável pela área técnica. Então montamos, por decisão do Departamento, uma pequena oficina mecânica, que existe até hoje aqui no Departamento e que produz toda uma série de pequenos equipamentos. Então eu estava com as duas coisas na mão: a oficina e o laboratório de foto-cinematografia. Então eu consegui juntar as duas coisas e não senti tanto o peso do problema instrumental, mas na verdade eu acabei praticamente desistindo da tentativa, porque efetivamente, o custo acabava sendo proibitivo. E lá pelas tantas é um custo que acabava sendo absorvido por mim, acabava tendo que pagar a conta do meu bolso, comprar película com o meu dinheiro. Existia a Fapesp sim, mas o problema era convencer - não era a Fapesp de hoje, hoje a Fapesp tem outra estrutura, tem outra dimensão - como explicar certos custos e certos 
investimentos na área de cinema num Departamento que era de Psicologia Experimental. Já por aí a coisa ficava meio difícil.

Mas na verdade eu acabei produzindo esse material das formigas, com 2 ou 3 versões desse material, com materiais diferentes acabei produzindo um material que foi utilizado como demonstração para a tese de doutoramento de um colega meu, de Ribeirão Preto, que trabalhava com abelhas, o José Elias, trabalho realizado em 16 mm, e mais algumas coisas esparsas. 1973 também coincide com a chegada, no mercado, dos primeiros equipamentos de vídeo portáteis. Ainda não eram os vídeos cassetes de hoje, mas já eram equipamentos portáteis, você podia levar para o campo. O primeiro que nós conseguimos adquirir, inclusive com verba da Fapesp, foi um equipamento da Aka, que era um gravador de rolo, com fitas de 1/4 de polegada e que já mostravam a sua potencialidade se não no lado, vamos dizer, qualitativo em termos da imagem, que ainda era uma imagem bastante precária em matéria de definição, branco e preto, mas na facilidade de utilização e no menor custo de operação. Então você podia gravar por um custo infinitamente menor, você podia eventualmente reaproveitar o próprio material.

Mas, o fato é que se ele efetivamente não substituiu a película já naquela época, tampouco substituiu hoje para certas finalidades, mas pelo menos sinalizou já uma direção em termos da tecnologia da imagem que depois se tornou uma realidade, então o negócio era mesmo para o lado do suporte magnético e não mais para o suporte fotoquímico para registro da imagem.

Apesar do alto custo da película, a película tem uma grande vantagem, você, se quiser, com uma gilete e um rolo de fita durex você monta um copião. Dá um pouco de trabalho mas você monta. E o vídeo exige uma ilha de edição, ou linear ou não. Digital ou analógica, mas exige uma ilha. Sem uma ilha a montagem fica muito prejudicada.

Se eu quero filmar interação da criança em atividades lúdicas, então eu vou para o recreio de uma escola infantil. Já começa a exigência do próprio pesquisador dizendo: mas eu queria selecionar todas as seqüências aonde existe, por exemplo, um toque corporal, quando uma criança toca na outra. Aí você começa a ter o problema se não de uma edição senso lato do termo, mas realmente o problema de uma edição senso restrito do termo. Como é que eu vou isolar essa seqüência? As ilhas VHS demoraram ainda para aparecer, então quando você trabalhava com esse equipamento de vídeo, de rolo 1/4 de polegada, as possibilidades de editar eram muito reduzidas, mesmo porque a gente tinha um vídeo só, e olha lá. Como é que você ia pedir dois 
vídeos prá Fapesp? O pessoal ia pensar que você era louco, porque, naquela época, o vídeo era uma coisa estranhíssima, pedir dois equipamentos ...

A primeira dificuldade realmente que se sentiu foi: o vídeo te oferece um horizonte bem mais amplo em termos de utilização, principalmente pelo seu baixo custo, pela sua facilidade operacional, mas te mostra também muito mais as limitações que já existiam na película, existiam "ma non troppo”, na pior das hipóteses a gente ia até a ECA, na ECA tinha uma moviola, e cê pegava e montava um copião na moviola, depois cê pedia pro Benê, ele montava o negativo prá você, depois cê ia no laboratório e mandava fazer uma cópia. Saía cara, tudo bem, mas o processo era muito simples em si. E o vídeo não, não tinha como passar de 1/4 de polegada, as máquinas de edição também, naquela época, não eram tão divulgadas assim.

São duas coisas que eu sempre faço questão de colocar como separadas: uma coisa é você utilizar o registro da imagem como uma forma de registro de dados, e outra coisa é você utilizar o registro da imagem como uma forma, vamos dizer, instrucional a respeito de qualquer evento que possa ocorrer, que seja lá a cópula entre macacos ou o debulhamento do milho por uma debulhadeira moderna. São coisas que eu acho que não se excluem, mas não se confundem, eu acho que você pode inclusive de um filme estritamente científico, aonde o sujeito passou anos registrando sei lá, comportamento sexual de baratas, você pode fazer disso um filme educativo, instrucional, senso lato do termo educação, para mostrar por exemplo um determinado tipo de comportamento sexual de insetos, que pode interessar o grande público como pode interessar ao pesquisador.

Agora, eu acho que é um pouco difícil você imaginar o contrário porque na hora que você está produzindo um filme, ou um vídeo, um material que você pretende que sirva como instrucional, educativo, você abre mão de certos rigores do controle dos procedimentos, principalmente no que diz respeito à sua seqüência, em benefício da compreensão do processo.

Eu tive uma vez um aluno aqui na psicologia, ele era veterinário, então ele estava interessado em fazer um vídeo onde mostrava o parto de uma vaca. Lá pelas tantas surgiu um problema desse tipo: eu posso cortar, vamos dizer, de um ponto aqui do parto para outro ou não? Depende do que você vai querer fazer com esse vídeo. Se você vai querer usar isso aí para aluno de veterinária, para eles saberem como é que é o parto de uma vaca é uma coisa, agora se você vai usar esse vídeo para especialistas e ginecologistas de vacas, aonde toda e qualquer contração do útero do animal no 
momento do parto é importante, porque é uma seqüência que prá ele tem um significado, então cê não pode cortar, se você cortar você tá falseando a verdade. Aí é um problema muito mais de filosofia da ciência, de modelos de procedimentos científicos do que de procedimentos técnicos e instrumentais.

A minha foi a primeira tese realizada em película, eu fiz questão de frizar que o meu trabalho principal era o registro em película. O texto que acompanhou era um texto mínimo, era coisa de 20 páginas, ilustrando uma hora e meia de imagens, causou realmente uma discreta celeuma na ocasião, no mundo acadêmico não precisa muito prá você ser malhado, mas eu fui duramente criticado, até, num certo sentido, insultado por colegas alegando até uma certa, quase que, desonestidade científica, acadêmica, da minha parte por querer fazer um trabalho deste tipo. E prevendo assim resultados desastrosos, que eu seria reprovado na tese, que a banca rejeitaria meu trabalho, eu realmente paguei prá ver. Eu fiz o trabalho, a banca que foi indicada foi uma banca que eu entendo ter sido uma banca de bom gabarito. Foi constituída toda de pessoas de notável reputação científica e acadêmica e meu trabalho foi aprovado com nota 10. Entendo que pelo menos não fui o único a defender esse ponto de vista, porque eu acho que a banca toda concordou com a minha colocação. Mas foi o primeiro trabalho na Faculdade de Filosofia, Ciências e Letras da Universidade de São Paulo a ser finalizado em película. Acho que primeiro e último, praticamente, porque eu não me recordo depois de nenhum outro trabalho. Mas isso corrobora aquilo que você acabou de dizer, realmente o mundo acadêmico ainda é muito restrito à forma tradicional de apresentação, ele aceita, vamos dizer, a imagem agora com relativa facilidade desde que essa imagem seja como uma ilustração de um texto, mas a mensagem principal deve ser ainda uma mensagem falada, impressa, escrita em palavras. Eu acho que é apenas um fenômeno de medievalismo contemporâneo.

Hoje conta o que você publica. O problema de publicar virou realmente um divisório das águas. Então todo mecanismo de poder dentro do grupo na academia está empostado no controle dos meios de publicação. Então, quem que publica, no fundo? Publica os melhores trabalhos? Eu estava conversando, há duas semanas atrás, com um dos nossos, eu considero, brilhantes cientistas contemporâneos aqui no Brasil, um sujeito que tem toneladas de coisas já publicadas, tem uma reputação científica internacional, e por coincidência é meu amigo de infância, então ele estava me contando de um resultado que ele conseguiu, sensacional. Realmente um dado importantíssimo sobre um problema da ciência atualíssima e que ele não consegue 
publicar. Que nenhuma revista, claro, internacional, porque ele estando nesse nível, obviamente nem se preocupa em publicar em revistas nacionais, quer dizer então que são as revistas americanas, as revistas inglesas), ele simplesmente teve seu "paper" rejeitado por duas ou três das grandes revistas e ele dizendo: "pô, mas tá todo mundo aí quebrando a cabeça, mas eles não querem publicar o meu paper”. E eu entendo, é o editor que vai resolver, são os assessores da revista que vão resolver. É uma panela, no fundo, que vai decidir isto. Então na verdade é muito mais importante você estar de bem com a panela, em certos casos, do que efetivamente você ter produzido um trabalho de grande valor. Esse é o lado ruim do processo. É que realmente ela acaba centralizando o poder de controle na mão de um grupo ou na mão de grupos e isso não deveria ficar na mão de grupos.

A publicação, não que não se deva, muito longe de querer acabar com a publicação científica, acho que a publicação científica é fundamental, ela caracteriza a passagem da alquimia para a ciência, das tentativas medievais, renascentistas, da ciência como nós a conhecemos a partir praticamente da metade do século passado prá cá. Mas eu acho que a excessiva ênfase pode levar a distorções desse tipo, quer dizer, você concentra o poder de controle sobre a informação científica na mão de grupos e o controle sempre que é centralizado, ele acaba sendo pernicioso. A universalidade do conhecimento, a universidade como nós a chamamos acaba de ser uma universidade, passa a ser uma particularidade. Então passa a ter o efeito contrário. E a outra coisa é que você realmente cria um esquema tão competitivo dentro do mundo acadêmico, dentro do mundo científico, que lá pelas tantas cê tem que lembrar aquele velho ditado: "quem tem pressa come crú".

Quantos e quantos pesquisadores no fundo acabam invertendo o processo? A publicação vira um fim em si e não o meio de dar conhecimento daquilo que você está fazendo ao resto da comunidade científica. Esse deveria ser o papel principal.

Bom, eu acho que em primeiro lugar, aquela colocação que eu fiz: ao nível da pesquisa o melhor produtor, o melhor operador para obter, pelo menos determinados tipos de materiais, teria que ser o próprio pesquisador e ele com muita freqüência não tá interessado nisto porque ele não conhece, apesar da simplicidade do procedimento, ele não quer conhecer. Ele acha muitas vezes que isso é um demérito para ele, ele largar, vamos dizer, senso lato do termo figurativo, largar o microscópio para pegar uma câmera de vídeo, não tem sentido, porque ele é um cara que mexe com altas instrumentações científicas. 
Eu não sei se é verdade ou não, mas alguém me contou uma vez que a USP, em relação a outras universidades de primeiro mundo, é aquela que tem maior número de técnicos em relação à cada pesquisador. Se você vai, sei lá, na Inglaterra, você encontra um prêmio Nobel no seu laboratório ele mesmo, eventualmente, lavando uma pipeta ou um vidro, etc. Aqui nós somos, ainda, os descendentes de uma universidade estilo "casa grande \& senzala".

Quer dizer, a USP foi criada na década de 30 para, em princípio, atender os filhos de fazendeiros de café arruinados pela crise de 29, e que não podiam mais mandar seus filhos estudar na Europa. E ao mesmo tempo, o fato do nazismo na Europa estar enxotando uma série de pesquisadores, seja pela sua nacionalidade judaica, seja pelos seus ideais políticos, então propiciou-se uma vinda para cá. Mas realmente eu sou testemunha viva dessa mentalidade porque quando nós mudamos o imóvel que a gente ocupava na Psicologia, naquela época, para a Cidade Universitária, onde nos construíram um galpão aqui perto dos galpões da Veterinária, eu fui criticado pela Chefe do Departamento, que não era catedrática, mas era regente de uma Cátedra de Psicologia, porque ela me viu carregando uma mesa junto com um funcionário, minha mesa, carregando pra levar para minha sala. Me chamou depois para me dizer, educadamente mas firmemente, que um docente não faz trabalhos desse tipo, que não ficava bem para o Departamento, para a Cadeira, então, era uma Cadeira do nível social e experimental, não ficava bem um professor que estivesse lá carregando uma mesa junto com um funcionário. E ela me deu essa bronca com toda honestidade. Era o pensamento dela e era o pensamento que predominava, e é o pensamento que ainda predomina em muitos casos. Quer dizer, coisa técnica é para os técnicos. Então voltamos àquele argumento que eu já expus, acho que ninguém pode ser o melhor operador de registro de imagem que o próprio pesquisador, que tá familiarizado com aqueles procedimentos, porque se ele vai querer formar um câmera man, um vídeo câmera que entenda tanto quanto ele daquele assunto, o cara vai trabalhar como pesquisador depois que é muito mais divertido.

Outro problema maior, outro problema grande também é aquela questão da incapacidade de se criar efetivamente um centro de produção, porque apesar do barateamento dos custos, quer dizer, esse barateamento dos custos não é tão barato assim. Nós acabamos de falar: uma câmera Beta digital, que é uma câmera que realmente te dá uma imagem de qualidade, a melhor qualidade que nós podemos ter hoje, você vai pagar algumas várias dezenas de milhares de dólares. Então não dá prá 
todo mundo ter uma câmera dessa e nem é necessário, na verdade freqüentemente você grava 2 horas de material, você tem material depois pra analisar durante 6 meses. Mas a idéia é: ou eu tenho meu equipamento ou então não, porque de repente eu vou trabalhar com equipamento dos outros, os outros vão querer que ..., sabe ..., nós ainda vivemos num mundo de ciumeiras, de desconfianças dentro da universidade, muito grande.

Então a idéia de um centro de produção, como sempre eu defendi também ao nível inclusive daquele tal Univídeo, quando foi começado eu fui convidado a participar das reuniões, eu sempre defendi essa idéia, quer dizer, então a universidade deveria ter era realmente uma central de produções aonde eventualmente o material só seria duplicado em casos efetivamente de extrema necessidade: 'Eu trabalho praticamente 24 horas por dia', tudo bem, então compra-se mais uma câmera para esse cidadão, mas $99 \%$ dos outros cidadãos não precisam de uma câmera Beta digital 24 horas por dia, não precisam de uma ilha não linear de 50, 60, 70 mil dólares. Pode perfeitamente ter uma ou duas ilhas não lineares ou quantas forem necessário para atender uma demanda da Universidade como um todo.

..., você poderia ter, vamos dizer, uma formação mista de trabalho, quer dizer, o pesquisador ficaria com a tarefa de resolver dois problemas: o problema dele que é de ter o registro de material específico que ele precisa e que exige uma dedicação inclusive intensiva ao problema e este material depois pode ser utilizado por outros, mas na elaboração de vídeos mais dirigidos a uma informação geral do público, à educação, mas prá isso você precisaria passar por cima dos pruridos individuais : 'Ah! Eu vou te ceder o material que eu gravei?', etc. Por quê? Porque existem inúmeros exemplos, efetivamente, situações nas quais o sujeito pega o material que o outro gravou ou que o outro escreveu e leva embora e diz que é dele.

E o grande problema é que a Universidade não é uma Universidade, é uma particularidade, como eu já tô dizendo prá você. Está se tornando cada vez mais difícil a colaboração dentro da Universidade. Eu acho que existe um clima até certo ponto, não sei, de desconfiança, dentro da Universidade que faz com que as pessoas tenham uma ressalva muito grande, um receio muito grande de partilhar o seu conhecimento, aquilo que elas tem, o seu equipamento, o seu conhecimento, então a coisa não vira, por causa disso. O sujeito diz: 'Quem me garante? Eu trabalho, trabalho, trabalho e a glória fica prá quem?' 
Mas teria que haver uma forma um pouco mais clara, talvez, no equacionamento dessas questões, né? Então, sei lá, o cara vai entrar com os conhecimentos de genética dele, você vai entrar com os seus conhecimentos de produção de vídeo, como é que fica a divisão das coisas? Não sei se é só um problema da Universidade, acho que é um pouco um problema geral, né, quer dizer, as pessoas estão cada vez mais competitivas, disputam meio metro no semáforo prá poder sair na frente do outro. Como é que você vai mudar aquilo que na verdade é toda uma atitude social, né?" 


\section{2 - Claudio Zaki Dib}

O Professor Claudio Zaki Dib, Doutor pelo Instituto de Física da USP, tem uma atuação intensa na pesquisa e no desenvolvimento da Tecnologia da Educação, com uma produção teórica (mais de 60 trabalhos científicos publicados no exterior e 12 livros científicos e educacionais editados) e também de planejamento e criação de materiais educativos para auto-aprendizagem (texto, áudio, vídeo, CD-ROM). Atualmente está coordenando o PAD - Programa de Apoio ao Docente, da Pró-Reitoria de Graduação da USP.

"O PAD Programa de Apoio ao Docente tem o objetivo mais amplo, compreende organizar palestras, seminários, mesas redondas, assessorar os docentes na análise de estratégias de procedimentos, tratar de apoia-los na implantação de programas alternativos, no sentido de desenvolver ações que visam a gradativa implantação de esquemas não formais ou menos formais de ensino.

Há uma demanda reprimida. Na verdade os docentes precisam de apoio e alguns se manifestaram na abertura desse Programa 'pela primeira vez a Universidade se preocupa conosco'. O que eu faço, eu trabalho com a tecnologia da educação aplicada a criação de sistemas de educação e treinamento sob encomenda, são pacotes elaborados sob encomenda para atender determinado público, determinados objetivos, determinada realidade, eu não faço a implantação, eu crio os materiais trabalhando com os especialistas no assunto, usando uma tecnologia muito especial de produção. A tecnologia da educação nada mais é que o uso da fundamentação científica na solução dos problemas na área educacional. Usamos princípios da psicologia, teoria de sistemas, teoria da comunicação, fundamentos socio-antropológicos, por ex. mecanismos de resistência à inovação, exatamente esse tipo de problema com o qual eu estou me defrontando nesse momento, nesse curso. Esses fundamentos científicos permitem então, a construção de uma tecnologia. Tecnologia não corresponde nem a máquinas, nem a equipamentos, mas na verdade é um estado de espírito distinto que eu vou buscar, que os malditos cientistas fazem e aplico isso para resolver os meus problemas, então eu tenho que ser eclético, eu tanto uso elementos sistêmicos, como os elementos de comunicação, como psicológicos, de diferentes linhas psicológicas.

Essa é a minha postura, eu me intitularia 'engenheiro educacional”, um tecnólogo educacional, na verdade tecnólogos não são apenas os que trabalham em 
engenharia, um médico pode ser um tecnólogo quando usa fundamentos científicos da biologia, da química, para resolver um problema, quando vamos a um consultório o médico é um tecnólogo, é um engenheiro biológico, o sociólogo que vai a uma favela e aplica os seus modelos sociológicos, então é um tecnólogo, é um engenheiro social. Tecnologia para mim tem uma concepção distinta, eu voltei às raízes da expressão, de uma origem grega, techné, transmissão de conhecimentos e habilidades profissionais. Dentro da tecnologia educacional o que se faz é busca, por ex., alternativas para se resolver problemas educativos, de treinamento, o que quer que seja, da área profissional.

Quando se busca uma solução analisa-se, faz-se um diagnóstico, estabelece-se uma nova estratégia, criam-se novos materiais, e esses materiais são produzidos com a melhor informação disponível, seja junto aos especialistas, seja junto aos materiais disponíveis, arquivos, etc, por ex., serão usados textos, serão usados textos mais meios interativos, serão usados textos para um auto-aprendizado, serão usados áudios, vídeos, vou usar vídeo não por que eu goste de vídeo, mas porque vídeo é o meio instrucional mais adequado para o alcance daquele objetivo, daquela população, dentro daquela realidade. Então o vídeo se coloca dentro dessa perspectiva do meu trabalho, é um dos meios que eu me valho para alcançar determinados objetivos, então eu não faço treinamento via vídeo, para mim isso é folclore, eu não sou produtor de textos impressos no papel, mas eu poderei fazer materiais impressos no papel, mas não se confundem com apostilas.

O Brasil não usa o áudio, fitas de áudio, é uma área maravilhosa, por que o áudio tem uma característica excepcional, você dá apenas uma parte, o restante o indivíduo constroe, então ele pode construir a cena toda. Quando nós damos a cena toda pronta, pode haver um questionamento no público 'ele está usando gravata, mas eu não uso gravata”, quando você põe só o áudio, ele constroe dentro da realidade dele. Tanto o áudio quanto o vídeo, a informática e outras técnicas de comunicação, são meio que eu me valho e nessa perspectiva não há um meio privilegiado, há um conjunto de meios para alcançar objetivos preestabelecidos. Eu não uso os meios sem levar em conta os objetivos, a população e a realidade, não adianta propor meios, o meio vídeo, se não há condições de exibição.

A produção de um vídeo vai envolver aquilo que nós chamaríamos de tecnólogo, que é alguém que domina a definição de estratégias, a sistemática de coleta de informações, o processamento dessas informações, então esse é o pessoal que vai 
participar possivelmente de um pré roteiro - porque não faz o roteiro de uma vez? Por que ele chega na superfície que o separa do profissional de teatro, de televisão, e ele não deve entrar nessa área se ele não estiver preparado, agora ele sabe processar informação e colocar num pré roteiro. Ele não conhece o assunto, ele é um tecnólogo da educação, ele domina os princípios da aprendizagem, os mecanismos de input, de output, controles de entrada, de saída, de feedback, seria uma equipe de analistas, pesquisadores, redatores, etc. Existe uma equipe que nós chamamos de especialistas no assunto, que é o pessoal que domina profundamente o assunto, mas que não tem, nem deseja, capacidade técnica para produzir materiais, ele conhece perfeitamente genética, isso não lhe dá nenhuma autoridade para fazer um vídeo de genética, agora eles vão interagir e dessa interação deve sair alguma coisa que nós poderíamos chamar de um briefing que seria, na verdade, um resumo organizado de todas as informações, na ordem, de tudo que tem que entrar. A partir daí tudo é checado, é revisto, em termos de qualidade de informação, esse briefing pode passar por um processo em que esses dois, o tecnólogo e o especialista do assunto, produzem o que chamaríamos de um pré roteiro. O pré roteiro já é o tratamento dessas informações, que são informações especiais, limpas, organizadas, já com algumas propostas de formas, aqui eles devem parar, aí entraria o terceiro grupo de profissionais, que é o pessoal de produção de vídeo. Esse pessoal vai produzir o roteiro, que vai ser checado pelos especialistas e pelos tecnólogos, para o controle de qualidade, e a partir do roteiro ele vai produzir o vídeo que, materialmente vai ser submetido ao controle de qualidade pelos tecnólogos, pelos especialistas.

Então temos um tripé para a produção de qualquer tipo de material, se for vídeo nós temos tecnólogos da educação, especialistas no assunto e os profissionais de criação de vídeo, se for texto, nós temos tecnólogos da educação, especialistas no assunto e aqui nós vamos ter um outro tipo de profissional, de programação visual, de arte gráfica, de produção gráfica, que é uma parte importantíssima.

Eu acho que educação é algo muito importante para ficar apenas nas mãos dos educadores, é um trabalho interdisciplinar, e quem vai participar desse grupo vai depender daquilo que se propõe, da proposta do trabalho. O ambiente da USP não favorece absolutamente nada sobre esse aspecto, a dificuldade de conseguir colaboradores numa área que não é privilegiada pela Universidade. As dificuldades estão associadas a uma mentalidade de que a Universidade de São Paulo é uma Universidade só de pesquisa, então o ensino é subvalorizado, a pesquisa é 
supervalorizada. Eu dou aulas que são muito bem recebidas, nunca tive nenhuma menção a esse fato, não há valorização, resultado educação é alguma coisa considerada como uma contribuição, os professores dão aula sem compromisso.

Nós não temos ainda uma Universidade no sentido pleno, ainda é um aglomerado de faculdades, eu vim da Maria Antônia, outros vieram de outros locais, cada um veio de um lado, tudo foi sendo juntado, não é uma universidade criada, ela é conservadora por que? Porque ela produziu muita coisa, muito importante, tem um volume de trabalho, níveis de pesquisadores muito elevados e, resultado, ela deitou em berço esplendido, ela produziu muito, viaja-se muito, participa-se muito, representa-se muito bem a Universidade. Então ela precisa mudar, os outros estão avançando nós não, a Universidade de São Paulo está muito atrasada."

\section{3 - Cristiano Mascaro}

Cristiano Mascaro formou-se arquiteto na FAU/USP em 1968, mas logo enveredou pela fotografia. Em 1973 volta para a Universidade para organizar e coordenar o Laboratório de Recursos Audiovisuais da FAU. Dedica-se a essa atividade até 1988, quando parte para a realização de sua vocação maior - fotografar as cidades, a arquitetura. Entre exposições e trabalhos para livros, atualmente faz a documentação para o projeto Monumenta, fotografando os principais conjuntos arquitetônicos do patrimônio histórico nacional.

"Na época eu trabalhava na Veja e resolvi voltar prá FAU, que foi uma coisa muito cara prá mim.

O que para nós parecia extremamente fascinante era a possibilidade de documentar a arquitetura paulistana, paulista ou brasileira. Não existe até hoje um registro sistemático e reunido num lugar só, e a gente imaginava que a gente já estava sendo pago prá isso, produzir fora é absolutamente caro. E aí que foi o grande entrave. Eu passei 14 anos na FAU me desgastando, me aborrecendo, errando, na tentativa de tocar essa parte que seria o cotidiano, eu pensei que seria só arrumar as pessoas prá tocar essas coisas, e a produção mesmo que seria a contribuição mesmo que a gente poderia dar de uma forma mais intelectual e com a formação que eu obtive na própria 
faculdade, esta: zero, zero. As poucas coisas que nós conseguimos fazer e daí com a contribuição valiosa que a gente teve, com a equipe que durante algum tempo chegamos a manter; o João (Musa), Raul (Garcez Pereira), Sérgio (Burge), o Toninho (Antonio Gonçalves da Silva), que foi um cara que atravessou esse laboratório carregando piano o tempo todo, e alguns outros que eu talvez possa esquecer o nome injustamente. A contribuição era não só técnica mas criativa, o Sérgio, Raul e João eram pessoas com formação acadêmica, nós formávamos um grupo, a gente brigava muito, no sentido de qual era a melhor forma de fazer.

O drama é o seguinte: a Universidade não pode competir com o mercado, trazer alguém do mercado era muito complicado, então a gente tinha que adaptar um auxiliar de escritório, um assessor administrativo, além dos equívocos todos, com a redemocratização surgiu o democratismo então todo mundo dizia: "todo mundo tem o direito de fotografar", eu tinha que montar um laboratório com laboratorista, o limpador de pia, tentando pagar o melhor salário, respeitá-lo como profissional, mas não podia... Esse foi um dos lados negativos, na Universidade você não tem aquela capacidade ou não consegue exercer a função de chefe. Eu queria demitir um fulano que tinha arrumado um outro bico no IPT, mal aparecia, mas a FAU teria que pagar uma grana, depositar no Banespa para abrir processo administrativo. Não sei se isso é bobagem minha, mas criou uma série de dificuldades, você não poder montar uma equipe de profissionais, só que o corpo docente exige que o trabalho seja bem feito $e$ sem querer culpar o corpo docente de tudo ele segrega aqueles que não fazem parte do grupo corpo docente, existe um preconceito, uma coisa de quartel. Aqueles fardados não respeitam os não fardados, quer dizer, quem não era docente era tido como pessoa que não está na carreira universitária, não está fazendo mestrado, nem doutorado. Quer dizer, eu fiz mestrado, fiz doutorado, não porque tivesse sendo estimulado, aliás a Élide Monzéglio foi minha professora e orientadora no mestrado, foi a única professora dos 50 ou mais professores com quem eu convivia, que eram colegas de turma ou de tempo de faculdade ou que tinham sido meus professores, que me estimulassem nesse sentido.

Eu então aproveitei o tempo que eu estava lá, que eu tinha disponibilidade e tempo de por no papel uma série de coisas. Tanto é que foi no mestrado que eu tentei botar no papel o que seria o laboratório de áudio visuais, a forma de desenvolver um aprendizado, estimular a vontade de os alunos poderem, através da fotografia e depois mais tarde seria o vídeo, a sair da faculdade e ver a cidade, que é o meio no qual o 
arquiteto atua, tentando projetar, equacionar, praticando a fotografia. Então eu enxergava dessa forma o laboratório dos alunos. Eles executando os trabalhos onde eles eram obrigados a ver criticamente a cidade e isso dura todo um trabalho, assim como num projeto de arquitetura você tem que pensar num todo, no seu desenvolvimento.

Eu imaginava, lá achavam pretensiosa, uma forma de documentar arquitetura, afinal eu era formado em arquitetura, tinha me tornado um fotógrafo profissional, me sentia com experiência para fazer, mas o pouco que a gente conseguiu fazer foi na base do "chutando a porta", na base da cotovelada. Um dos poucos projetos que a gente conseguiu fazer foi quando houve a CLEFA-Conferência Latino Americana de Ensino da Arquitetura, uma reunião de escolas de arquitetura latino-americanas que, naquele ano de 80 e poucos, foi na FAU, e onde ia se discutir a experiência de ensino de todas essas universidades.

Falei para o diretor da faculdade que o laboratório de recursos áudio visuais já tinha mais ou menos 10 anos de existência e tinha uma experiência a contar e a ser discutida. Resposta de pronto que nós recebemos: 'não temos verba'. 'Não seja por isso, eu posso arrumar um patrocínio', e a Fotóptica entrou com as ampliações todas, foi uma ajuda enorme, e o Fábio Magalhães, que na época era Secretário da Cultura, também entrou com uma grana suficiente prá gente comprar filme, produzir. E daí a gente teve a idéia de mostrar como a fotografia podia ser uma linguagem ou um meio de interpretação, de colocar em discussão a vida de uma cidade como São Paulo, e como o João Musa já tinha feito um trabalho anterior numa favela, eu iria fotografar o centro da cidade e o Raul Garcez a periferia, prá mostrar as diferenças da 'cidade clandestina e da cidade oficial'.

Antes da gente começar a trabalhar eu fui comunicar o diretor que a gente tinha conseguido uma verba razoável em função até do que a Faculdade tinha, 'Poxa, então você vai repassar parte desse dinheiro prá gente', disse o diretor, 'Em absoluto'. Ainda levamos várias rasteiras porque nos tiravam de lugar, mas com o patrocínio que a gente conseguiu a gente montou uma exposição enorme com painéis, pedimos a professores que eram simpáticos à idéia que fizessem textos. A exposição foi um sucesso, saiu na primeira página do jornal ...

Esse foi o início de uma certa má vontade, alguns comportamentos que me deixam aborrecido quando eu me lembro, nas relações entre laboratório e professores. Um professor falou prá mim: 'o pessoal não te suporta porque você quer ter essa 
independência toda'. Eu só quis ter essa independência porque eu não tinha solidariedade alguma.

Todas as nossas idéias a respeito do que o laboratório poderia auxiliar, apoiar, complementar o ensino da arquitetura, que é de fato responsabilidade dos Departamentos, a gente mandava as idéias através de circulares, comunicados, e não recebia sequer uma resposta.

Quando chegou o vídeo, nem a ECA tinha equipamento igual, os alunos queriam usar e o diretor mandava segurar. $O$ corpo docente foi comunicado que o equipamento de vídeo estava à disposição e nenhum professor se manifestou.

Vídeo foi adquirido com verba do CNPq, o vínculo era que a FAU produziria não sei quantos vídeos, em não sei quanto tempo, de interesse do CNPq. Isso nunca foi feito. Foi um processo longo, maluco. Prá comprar era importação direta, pela primeira vez ouvi falar em preço FOB e eu cheguei a fazer uns dez orçamentos, a cada semana o dólar mudava de valor. Depois de meses chegava, aí precisava contratar um despachante especializado em alfândega, não tem dinheiro prá fazer seguro ... É muito difícil, mas é possível administrar uma coisa pública, a EDUSP se modernizou.

Tentando resumir, existe um conflito grande entre o corpo docente que é a espinha dorsal da Faculdade e daqui prá frente vai ser cada vez mais, com computação, com fotografia, com vídeo, que requer pessoal não docente, técnicos especializados que tenham uma competência na área específica de cada um, superior a dos professores, e os professores não admitem, eles não entendem o que é roteiro adaptado, é como um filme feito de um livro, é outra linguagem.

Eu ouvi uma vez de um professor que os professores decidem o que fazer e os técnicos como fazer. Tudo bem, eu acho que não há restrição a isso desde que os professores 'bolem' o que fazer, mas não 'bolam'. Então aqueles técnicos que tem uma experiência profissional começam a tentar forçar, a fazer e daí criam-se os conflitos, $e$ foi o que aconteceu comigo.

Então entre mortos e feridos a experiência foi muito boa prá mim mas, existe fundamentalmente isso, uma incompatibilidade entre a atividade docente e uma atividade criativa como na nossa área. Felizmente hoje eu tenho um trabalho pessoal que eu pude desenvolver por ter estado na FAU, não que a FAU tivesse me permitido, foi porque eu fui abrindo caminho.

Em um ano ou dois, depois que eu saí da FAU, eu fotografei mais arquitetura do que os 14 anos que eu passei lá dentro." 
Os problemas que vão sendo apontados nos depoimentos, manifestam-se simultaneamente, repetidamente, exaustivamente. Considerei válido inserir aqui tais depoimentos principalmente por representarem posturas distintas em relação ao audiovisual na Universidade e pelas trajetórias pessoais, na busca da realização de suas idéias, nas suas conquistas e nos seus limites.

O Prof. Mario Guidi coloca sua própria história profissional, seu empenho no uso da imagem científica, como ele mesmo diz, strictu sensu, as dificuldades de apoio material e a resistência do meio acadêmico a esse uso como forma de expressão de um conhecimento. Aponta ainda o problema da autoria intelectual e do compartilhamento da informação. De seus comentários podemos perceber o potencial do registro audiovisual para a Pesquisa e para o Ensino e o que poderia ser um vasto banco de imagens científicas à disposição não só de pesquisadores, mas para toda a sociedade.

O Prof. Claudio Zaki Dib é muito claro ao expor uma metodologia e propósitos de utilização dos diversos recursos audiovisuais a serviço do Ensino. Desfaz a aura de fascinação que a tecnologia exerce na Universidade, justamente onde existe conhecimento e crítica para o discernimento. Aponta para o risco de se ver a técnica como solução, relegando-se a questão do processo ensino/aprendizagem para um segundo plano e alerta - a morosidade desta Universidade em iniciar ações efetivas de uso adequado das novas tecnologias da comunicação nos afasta da sociedade.

O depoimento de Cristiano Mascaro é, para mim, o mais contundente a respeito de dois aspectos fundamentais do audiovisual na USP: primeiro é a dificuldade de integrar os docentes na atividade de produção audiovisual, e o que essa dificuldade reflete (também apontado pelo Prof. Guidi) é a intransigência em não aceitar uma divisão de trabalho com um saber que não o seu, que é um saber teórico-técnicoartístico. E também, novamente, a intransigência em aceitar uma parceria de trabalho com um profissional que não é da mesma hierarquia, que não faz parte do seu grupo, que é apenas de outra categoria. Em segundo, é a dificuldade que a Universidade demonstra em aceitar e apoiar como sua, não de alunos e nem de professores, uma produção que não é propriamente científica, mas cultural e artística. O saber/fazer 
artístico não tem o reconhecimento acadêmico enquanto produção de conhecimento, não faz parte da carreira acadêmica.

É justamente a partir da incorporação de outras formas de pensar e fazer conhecimentos que a Universidade poderá buscar novos paradigmas para reconstruir-se como uma entidade da sociedade. A Universidade, além de tudo que lhe é intrínseco, suas tradições e seu fazer crítico, também precisa se perceber como um espaço onde esta sociedade se expõe e se transforma, não deve recusar o novo que a sociedade lhe traz.

Nelson De Luca Pretto, em sua tese de doutorado ${ }^{88}$, assim apresenta a questão,

"o conjunto de análises apresentado indica a necessidade de se trabalhar para a construção desta cultura audiovisiva nas Universidades, como um passo significativo para a aproximação da Universidade, e por extensão das escolas nos demais níveis, com o mundo externo a ela. Um mundo, como já foi enfatizado, de imagens, comunicação e informação.

A perspectiva adotada aqui é a de formar um novo ser humano, diferente daquele que estamos formando, e isso implica em uma concepção mais globalizante da produção do conhecimento, incluindo aí uma visão mais globalizante para as próprias estruturas audiovisuais das Universidades.

Nesse sentido, produção, distribuição, utilização, avaliação e pesquisa, constituemse em partes interdependentes de uma prática articuladora, que, também ela, tem na globalidade e na integridade seus vetores mais fundamentais.

Este conjunto de reflexões indicam, necessariamente, que não adianta se repensar isoladamente as políticas audiovisuais para as Universidades. Na verdade, poderíamos ir mais longe e até afirmar que a questão não é de política audiovisual, mas de uma política educacional para as Universidades brasileiras. Estas, neste momento histórico, precisam, necessariamente, refletir, nas diversas instâncias de planejamento universitário, sobre a necessidade de considerar a realidade do mundo contemporâneo e repensar a sua relação com a sociedade como um todo."

${ }^{88}$ Pretto, Nelson De Luca. A Universidade e o Mundo da Comunicação, análise das práticas audiovisuais das universidades brasileiras, tese de doutorado, São Paulo, ECA/USP, 1994. 


\section{5 - Problemas da produção de vídeo na USP}

As questões que serão aqui apresentadas partem da perspectiva da utilização dos recursos de produção de vídeo em atividades de Ensino, Pesquisa e Extensão da Universidade e que, em qualquer uma dessas finalidades, os problemas manifestam-se da mesma forma. Também é um pressuposto desta análise que o uso dos recursos atenda a uma demanda de materiais elaborados, não apenas como registro bruto de imagens e sons, e isso implica no trabalho de uma equipe de técnicos capacitados a executarem as etapas básicas da produção audiovisual - planejamento, captação e finalização. Mesmo no registro de experimentos científicos considero necessário que o material receba um mínimo de tratamento final, como a inserção de dados que facilitem a indexação e o acesso às imagens, ou de outros dados pertinentes à pesquisa documentada, como data, hora, local, número da amostragem, metodologia e procedimentos, etc, assim esse material se torna apto a constituir um banco de dados, de imagens, que outros pesquisadores poderão utilizar.

Vou comentar os problemas de produção de vídeo na Universidade em seus aspectos funcionais: do que é necessário para produzir e de como se realiza a produção.

\section{1 - Recursos humanos}

Em geral todos nós já reparamos na quantidade de nomes que passam na tela após assistirmos a um filme ou um programa de TV, seja uma novela ou uma reportagem. Isso decorre, simplesmente, de ser, a produção audiovisual, um trabalho de equipe. Sem dúvida, há muita diferença entre uma produção de um filme de longa metragem e de um documentário de divulgação científica. É possível acumular funções e trabalhar em pequenos grupos, no caso de documentários é até recomendável uma equipe reduzida, mas o processo de produção, no geral, será o mesmo.

A estruturação de um setor de produção de vídeos não se limita à escolha de equipamentos e à definição de propósitos a serem alcançados, estes são aspectos importantes, mas não únicos. Equipamentos sozinhos nada fazem e não será apenas um 
funcionário o suficiente para desenvolver uma produção, como é o caso de muitos setores de audiovisual existentes na Universidade. É necessário formar equipes e isso envolve problemas de outra ordem, da própria política de recursos humanos da Universidade e da concepção que esta Universidade tem sobre esse tipo de trabalho. Por exemplo, os funcionários da USP cumprem uma jornada de trabalho pré-fixada e não há o pagamento de horas extras. Ora, o trabalho de produção de vídeo apresenta situações de gravações, e isso é comum de acontecer, que não podem ser interrompidas porque termina o horário do expediente; ou, para gravar uma entrevista com alguma figura notável a equipe estará sujeita à agenda do entrevistado e se o evento for marcado para as 18:00 horas, não poderá ser realizado?

\subsection{1 - Composição de uma equipe de produção de vídeo}

A produção de vídeo implica em operar um certo conjunto de equipamentos, câmera, tripé, monitor, iluminação, microfones, de complexidade relativa ao nível de sofisticação específico dos mesmos. Implica também, no planejamento do trabalho de acordo com princípios básicos da linguagem audiovisual e dos procedimentos de organização das atividades concernentes. Compreende, assim, um saber teórico-técnicoartístico, que será mais técnico ou mais artístico, conforme os objetivos colocados para cada produção. A organização do trabalho e a operação dos equipamentos tem seus pressupostos, os aspectos técnicos exigem funções específicas. Considerando, para efeito da presente análise, uma proposta de produção de vídeos, sistemática e continuada, para finalidade de divulgação científica, uma equipe de vídeo deverá atender, no mínimo, às seguintes atividades (o Anexo V apresenta um descrição dessas atividades): 
- direção,

- pesquisa e roteiro,

- produção,

- captação de imagem,

- assistência técnica,

- iluminação,

- captação de som,

- edição,

- divulgação/distribuição dos programas.

Outras atividades concorrem para uma produção de boa qualidade: locução, computação gráfica, trilha sonora/música, cenário; mas sua presença é pontual, podem ser contratadas temporariamente e nem todas são sempre necessárias. Para o exercício das funções básicas, com a sobreposição delas, é viável compormos uma equipe com 5 pessoas da seguinte forma:

- diretor/roteirista

- produtor/divulgador

- operador de câmera/iluminador

- operador de áudio/assistente técnico

- editor

Tal composição de trabalho está aqui colocada apenas como um exemplo, há outras possibilidades de combinação das funções até em menor número de pessoas, sempre com o desempenho de duas ou mais funções por funcionário. A situação de acúmulo de funções técnicas é inevitável na atual estrutura funcional da Universidade e considero a equipe de cinco pessoas necessária e suficiente para a realização simultânea de produções audiovisuais num processo contínuo de trabalho. O importante, para a formação da equipe, para o incremento de sua sinergia, é a realização a médio e longo prazo de vários programas. Essa vivência propiciará o aperfeiçoamento da técnica, a elaboração de uma linguagem audiovisual apropriada às finalidades da Universidade e a integração dos esforços de trabalho da equipe. 
Cabe ressaltar ainda, que uma equipe de produção de vídeos não trabalha isoladamente. Como já foi apontado anteriormente, nos depoimentos dos Profs. Claudio Zaki Dib e Samuel Pfromm Netto, esta é uma atividade interdisciplinar, são vários os especialistas que participam, inclusive docentes e pesquisadores.

\subsection{2 - Formação profissional}

Um dos problemas que surge para compor uma equipe de produção de vídeo, é que a remuneração oferecida pela Universidade é muito defasada em relação aos salários da iniciativa privada e, dificilmente, um profissional do mercado aceitará tal condição de trabalho. A Universidade vai ter que formar o seu profissional de vídeo, seja ele um funcionário remanejado ou mesmo no caso de pessoa que venha a ser contratada, pois as características do trabalho de produção audiovisual na Universidade são peculiares conforme comentaremos a seguir.

É específico dessas atividades no ambiente da Universidade, que, como exposto no item anterior 'Composição de uma equipe de produção de vídeo', o funcionário desempenhará várias funções, será cinegrafista, editor, roteirista, implicando numa formação técnica polivalente. Isso contraria a regra geral dos profissionais do mercado que buscam aprimorar suas especializações conforme a evolução dos modos de produção de cinema, televisão e, mais recentemente, multimídia e sites para internet. Essa polivalência é uma característica do ambiente de trabalho da Universidade e é condição para que possamos produzir audiovisuais, e será, portanto uma qualidade a ser desenvolvida pelos funcionários da área.

Tal situação gera uma demanda por cursos de capacitação e isso tem passado despercebido pela USP, atualmente não existem programas oficiais de cursos na área de produção audiovisual. ${ }^{89}$. Ainda no ano passado, 1999, a Coordenadora Acadêmica do

\footnotetext{
${ }^{89}$ Conforme relatado anteriormente, o UNIVÍDEO/Cecae, em 1994/95/96, realizou cursos de capacitação para funcionários e para docentes e pesquisadores, em 97 os cursos para funcionários foram incorporados, como treinamento, pelo Departamento de Recursos Humanos da Reitoria e depois disso não mais foram realizados. Ressalte-se que tais cursos eram apenas introdutórios e só na fase seguinte, de especialização, é que se daria uma capacitação efetiva.
} 
UNIVÍDEO, Profa. Dra. Marília Franco, elaborou um projeto de cursos dirigido para capacitação de docentes, que foi encaminhado ao Departamento de Recursos Humanos da Universidade e está aguardando encaminhamento (o Anexo VI apresenta cópia deste projeto).

A tecnologia do vídeo acompanha a evolução contemporânea da informatização dos equipamentos. Câmeras e sistemas de edição já incorporaram os processos digitais e exigem de seus usuários conhecimentos de operação de softwares. Há uma grande diferença entre o uso standard de um equipamento profissional (nem considero os aparelhos de uso amador, isso é incompatível com uma produção de qualidade), e o seu uso completo, explorando todos os ajustes que o equipamento oferece, que é quando se obtém o melhor aproveitamento da tecnologia. A operação dessa tecnologia implica numa capacitação que envolve a informática, é recomendável um conhecimento básico de inglês, e, tratando-se de um processo constante de atualização, desenvolver o que o Prof. Claudio Zaki Dib designou como habilidades superiores, "daqui por diante tem que ser o domínio de habilidades superiores, o conhecimento já não é tão importante quanto as habilidades, ...precisa saber buscar a informação, saber pegar 40 mil na internet e tirar aquelas 20 que vão ajudar você a resolver aquele problema que você equacionou, ..."

Ora, o funcionário que vai desempenhar tais atividades precisa de uma formação de nível superior, pois na graduação desenvolve-se uma capacidade de busca, análise e síntese de informações e conhecimentos. No entanto, não é do conhecimento dos funcionários desta Universidade a existência de algum programa de incentivo e apoio à realização de cursos de graduação ou de pós-graduação, que a própria USP dispõe, e que representaria uma melhor qualificação dos funcionários para os trabalhos por eles realizados. 


\subsection{3 - Plano de Classificação de Funções na área do audiovisual}

As questões relativas aos recursos humanos serão analisadas tendo em vista a estrutura funcional e a administração de pessoal da USP e referem-se aos funcionários, termo usado geralmente nas universidades para os profissionais das atividades administrativas ou técnicas, distintos daqueles que executam atividades de ensino e de pesquisa, os professores ou docentes. Cada categoria tem seu próprio plano de carreira com diferentes formas de evolução profissional.

A estrutura funcional da USP contempla a área audiovisual com poucas funções - operador de audiovisual, operador de som, jornalista (o Anexo VII apresenta a descrição das funções compatíveis com a produção audiovisual). A USP tem utilizado outras definições, em seu Plano de Classificação de Funções, para enquadrar funcionários que trabalham na produção de vídeos, tais como: analista de comunicação visual e produtor de comunicação visual, que são, evidentemente voltadas para a comunicação visual, ou seja, o planejamento de sistemas visuais para informação pública em ambientes internos ou externos, com recursos gráficos e/ou cênicos. É flagrante a inexistência de designações mais adequadas à produção de vídeo, de cinema, de televisão e mais ainda de CD-ROM e sites e a implicação disso sobre a vida profissional do funcionário é negativa, afinal ele está contratado sob uma designação que não representa suas atividades.

Há também uma questão, que é geral para o funcionalismo na USP, trata-se da morosidade na progressão da carreira. Não há mecanismos ágeis para a valorização do desempenho profissional. Muitos funcionários, com vários anos de Universidade e de conhecimento do trabalho no meio acadêmico, habituados a lidar com pesquisas científicas e com atividades de Ensino, estão no mesmo nível salarial de um funcionário recém contratado. Essa situação cria uma insatisfação extremamente prejudicial, principalmente em atividades que envolvam criatividade e atualização tecnológica, como é o caso, da produção audiovisual.

Vale destacar que as tão necessárias habilidades superiores de que fala o Prof. Dib envolvem, além das habilidades técnicas, a compreensão dessas produções como mídias, isto é, como peças de comunicação social. Do mesmo modo vale lembrar o 
depoimento do Prof. Guidi quando sabemos que há funcionários que foram formados no contato com os pesquisadores e que adquiriram, portanto aquelas qualidades específicas de um técnico privilegiado para aquela área de conhecimento. Ora, a Universidade que mal estrutura as funções básicas da produção audiovisual não percebe que seus funcionários realizam atividades que ultrapassam a mera capacitação técnica, que na interação com o trabalho de cientistas e de professores desenvolvem uma formação sofisticada, de difícil comparação com as práticas profissionais usuais na iniciativa privada. Nada disso está minimamente contemplado nem no Plano de Classificação de Funções e muito menos nos manuais de avaliação de desempenho funcional.

\subsection{4 - Cooperação na produção}

Pesa ainda, sobre a questão em foco, os problemas de relacionamento entre professores e funcionários apontados nos depoimentos do Prof. Mario Guidi e de Cristiano Mascaro. O trabalho integrado, onde saberes distintos compartilham o mesmo espaço, requer o empenho dos participantes na contribuição e no respeito às capacidades específicas de cada um. Portanto, cabe, por exemplo, ao Doutor em Botânica elaborar um texto do conteúdo a ser roteirizado, o briefing, como explicou o Prof. Zaki Dib, um material selecionado e organizado. Não será possível ao roteirista desenvolver o seu trabalho se lhe for apresentado um compêndio, ou uma tese, como base para o roteiro.

Aos especialistas em produção de vídeo caberá solucionar, da melhor forma possível, os problemas técnicos e a criação de um material eficiente para a informação e para a comunicação desejada. O problema da competência das tarefas, ou dos direitos autorais do programa realizado, deveriam ser colocados com transparência e não escamoteados por relações de subordinação hierárquica. 


\section{2 - Equipamentos e tecnologia de produção de vídeo}

Os equipamentos para a produção de vídeos constituem um conjunto detalhado de vários itens, no senso comum fala-se sempre da câmera e da edição, mas são vários os itens que estão embutidos aí: tripé para câmera, baterias, lentes, filtros, microfones, cabos, monitor de vídeo, mesa de áudio, equalizador, gerador de caracteres, etc. É esse conjunto que vai garantir a funcionalidade do sistema de equipamentos para produção de vídeo. Portanto há uma questão básica a considerar que é a configuração do sistema de equipamentos, todos os itens do conjunto precisam ser compatíveis entre si. O processamento de imagens num sistema de vídeo consiste na captação e na copiagem dessas imagens e na interferência sobre seu aspecto (valores cromáticos, contraste, dimensão, textura, movimento, duração). O melhor desempenho do sistema é obtido quando os equipamentos utilizados operam sob os mesmos parâmetros técnicos, evitando-se a transposição da imagem de um padrão para outro.

A tecnologia de vídeo apresenta uma diversidade de tipos de fitas, de processos de gravação, de tipos de sinais de áudio e de vídeo, aos quais corresponderão diferentes qualidades de imagem e de som e de custos. Atualmente, com a coexistência de

equipamentos analógicos e digitais, a complexidade dos sistemas aumentou e a integração dos diversos tipos exige cuidadoso planejamento. Assim a qualidade técnica desejada para uma produção de vídeo e os custos dos equipamentos, são quesitos definidores do sistema que se pretende montar (no Anexo VIII apresento um quadro comparativo dos atuais tipos de equipamentos de produção de vídeo).

\subsection{1 - Processo de compra}

$\mathrm{O}$ que se verifica nas Unidades da Universidade que adquiriram equipamentos com recursos próprios, em geral, é que a compra buscou o preço mais baixo, não importando muito as especificações técnicas. Solicitou-se uma câmera de vídeo e só, sem maiores detalhes, daí veio a grande quantidade de câmeras tipo VHS (e o próprio nome informa Video Home Sistem) espalhadas pela USP. 
A aquisição de um sistema completo de produção de vídeo, de boa qualidade técnica, significa um alto investimento e mesmo com a captação de recursos externos, como fizeram as Unidades que dispõe de sistemas de produção, dificilmente é viável a aquisição, de uma só vez, de todos os equipamentos. Recorre-se, então, à compra gradual dos itens necessários. Como a tecnologia tem evoluído em velocidade crescente, a obsolescência também é rápida e a aquisição gradual de equipamentos acaba implicando em dificuldades de integração de novos equipamentos aos já existentes. Nesse sentido a escolha dos tipos de equipamentos deve ser baseada em especificações técnicas bem detalhadas e preferencialmente definidas junto a especialistas da área.

É muito importante também que os equipamentos sejam comprados em função do projeto de produção que a Unidade ou o Departamento queiram desenvolver. É a partir dos propósitos colocados nesses projetos que se deveria optar por uma ou outra tecnologia e não simplesmente por menor preço. O processo de compra de materiais, pelas normas da Universidade, é extremamente prejudicial, pois limita as opções de fornecedores e, consequentemente, de marcas de equipamentos e de seus preços.

Recentemente adquirimos, para o Laboratório de Vídeo da FAU, um scanner, que, sabíamos, era oferecido em lojas do ramo por um preço bem abaixo do que estava sendo proposto por fornecedores credenciados na USP. Em outras ocasiões, em que eu buscava opções de marcas e preços de equipamentos de vídeo, os vendedores, ao saberem que se tratava de compra pela Universidade, simplesmente encerravam a conversa dizendo que não negociavam com órgão público.

Independente da questão, justa, de que as empresas fornecedoras devem estar com seus recolhimentos fiscais em dia, as demais exigências, pagamento em conta do banco que detém os recursos do Estado, prazo de pagamento, acabam afastando da Universidade fornecedores de equipamentos de qualidade, com bons preços.

Como não existem fabricantes nacionais, a opção de realizar a importação direta, através do setor competente da Reitoria, revela-se morosa e exige a intermediação do representante da marca no Brasil, para efeito de garantia e assistência técnica. No âmbito das normas internas, definidas pela administração da USP, caberia uma 
verificação das alternativas possíveis para os procedimentos de compra, visando o melhor aproveitamento dos recursos investidos na aquisição de tecnologias específicas.

\subsection{2 - Cooperação técnica interunidades}

Outra questão sobre equipamentos para produção de vídeo, pelas Unidades que não dispõe desses recursos, refere-se à cooperação das Unidades já equipadas. O projeto UNIVÍDEO adotou como norma de uso dos equipamentos sob sua responsabilidade, o pagamento de uma taxa destinada à manutenção dos mesmos. Essa taxa, calculada em $30 \%$ do preço cobrado por empresas do ramo, permitiria, eventualmente, um investimento na aquisição de novos itens ou na melhoria da infra-estrutura física.

Tal procedimento tem sido adotado pelo Laboratório de Vídeo da FAU e nem sempre resolve a questão. De fato, além do equipamento é necessário que o funcionário especializado esteja disponível para atender ao serviço e, sendo um setor produtivo, geralmente o tempo livre será escasso. A cooperação interunidades é positiva e estimula a produção audiovisual, porém o incremento significativo na quantidade de programas realizados deverá buscar outras vias.

A idéia de uma Central de Produção na USP é recorrente. Em seu gigantismo, com quase 50 Unidades de Ensino, de Pesquisa e de Extensão, com números de alunos, professores e pesquisadores sempre na casa dos milhares, a USP teria, numa Central de Produção, um alto investimento a fazer e exigiria um cuidadoso planejamento da administração desse serviço. A principal questão aí embutida é do risco da centralização do poder de decidir as prioridades, ou mesmo das impossibilidades de atendimento das solicitações. Suprir a toda a demanda da Universidade seria quase utópico.

Um primeiro equacionamento do problema pode se dar por uma delimitação do serviço oferecido. A etapa de edição, por exigir maiores investimentos em equipamentos e permitir uma otimização de uso, mediante um detalhado roteiro de edição e a adequação do agendamento, poderia ser o principal serviço da Central. 
As gravações, sobre as quais incidem muitas variáveis ( locações, condições do tempo, acompanhamento de procedimentos de pesquisa etc,) ficariam a cargo dos recursos do interessado e de sua Unidade de origem, tanto equipamentos como pessoal técnico.

Trata-se de uma idéia potencialmente capaz de gerar um grande impulso à produção audiovisual da Universidade, porém sua pertinência deve ser fundamentada num planejamento preciso de todos os aspectos envolvidos na produção de vídeos,

desde a oferta de cursos de capacitação para docentes e funcionários, cursos de especialização, até a definição de estratégias de divulgação e distribuição dos materiais finalizados, ou seja, com o estabelecimento de uma política de audiovisual para a

\section{Universidade.}

\subsection{3 - Infra-estrutura física}

Um aspecto pouco considerado nos projetos de sistemas de equipamentos de vídeo desenvolvidos nas Unidades da USP, é o tratamento da infra-estrutura física do local de instalação desses sistemas.

Há recomendações específicas quanto ao controle de temperatura e umidade do ambiente e a não observação dessas especificações pode gerar dano ao equipamento. Principalmente os aparelhos de edição, que são os mais exigidos em tempo de uso, devem funcionar em ambiente climatizado e livre de poeira, mas geralmente por motivo de escassez de verbas, os setores de audiovisual são instalados em salas simples, sem maiores cuidados. Tais projetos deveriam também, incluir itens de segurança, como sistema de alarme, contrato de seguro contra roubos e acidentes, minimizando prejuízos ao patrimônio público. 


\section{3 - Processo de produção de vídeo}

Os procedimentos de produção envolvem outras questões, além das técnicas.

\subsection{1 - Formatos audiovisuais}

Ao iniciar uma produção de vídeo criam-se expectativas, mobilizam-se recursos, cada pessoa envolvida terá uma idéia na cabeça e impõem-se a necessidade de algumas definições como orientação para o trabalho conjunto. Geralmente a demanda é colocada por professores que desejam registrar um evento ou produzir um programa sobre uma pesquisa. A solicitação do serviço deveria conter informações para que o técnico em vídeo pudesse preparar um plano de trabalho conforme os métodos usuais de produção audiovisual, com um ante-projeto do vídeo e de suas demandas técnicas e então apresentá-lo ao solicitante para analisarem, conjuntamente, o desenvolvimento do projeto de produção. As informações preliminares que a solicitação do serviço deve conter compreendem:

- o objetivo do vídeo,

- a que público se destina,

- qual o conteúdo informativo,

- onde serão as gravações e o que se pretende gravar

- quais recursos, materiais, humanos e financeiros, estarão disponíveis.

Com isso o interessado estará, de fato, manifestando sua expectativa quanto ao vídeo e não, necessariamente, como ele será. A produção de vídeo implica no desenvolvimento de um projeto, é um processo de trabalho que vai exigir tempo e dedicação das pessoas envolvidas, cumprindo as etapas necessárias.

Há uma noção simplista na Universidade, 'se tem a câmera e um funcionário é só pegar uma fita e sair para gravar'. Elimina-se todo o planejamento, deixa-se o roteiro para depois, os problemas técnicos ficam para o funcionário e começa a gravação de um material sem a análise prévia de qual é a forma audiovisual adequada para aquele caso. 
É um método que já observei em várias produções da Universidade ${ }^{90}$ e foi mencionado por outros funcionários que participaram dos cursos que o UNIVÍDEO realizou.

Tome-se, por exemplo, a situação de gravações de palestras, tão comum de ser solicitado aos setores de audiovisual da Universidade e que geram uma enorme quantidade de material nunca editado e nem mesmo assistido. Exceto quando o palestrante utiliza projeção de slides ou de retroprojetor, a informação é $100 \%$ áudio e seria mais prático registrar a fala em fita K-7, transcrever e colocar à disposição como texto impresso. Em palestras, a pessoa usa de uma retórica extensa, repetitiva, e isso ocupa um longo tempo pouco adequado ao vídeo, um ciclo de palestras de dois ou três dias de duração terá de 12 a 15 horas de material gravado e, dos muitos eventos que já gravamos na FAU, pouquíssimos foram editados.

A validade do uso do vídeo em tais casos pode ser obtida com um planejamento adequado de produção, por ex. realizar uma entrevista com o palestrante, combinada com antecedência, com uma pauta previamente elaborada e realizar a gravação num ambiente apropriado, longe do burburinho dos auditórios. O palestrante poderá então apresentar para o entrevistador, e para a câmera (que faz o papel do público!), já uma síntese da sua explanação, ele mesmo fará um corte, elaborando seu discurso de forma mais objetiva, resultando num material de melhor qualidade técnica e de conteúdo, para ser colocado à disposição de alunos e outros interessados.

Uma primeira questão a ser colocada é - qual é o tratamento audiovisual cabível para a demanda apresentada? Para o registro de eventos acadêmicos, conforme exemplificado, é pertinente um tratamento jornalístico, e serão adotados os procedimentos adequados. Para a produção de um vídeo sobre uma pesquisa serão outras as providências.

A produção de documentários não utiliza roteiros detalhados, como na produção de ficção ou de publicidade, mas existe um planejamento, o tema escolhido é pesquisado, prepara-se um texto que resume as informações levantadas e que orientarão as gravações, elabora-se uma pauta para entrevistas, as locações são verificadas com

\footnotetext{
${ }^{90}$ As duas Mostras de Vídeo organizadas pelo UNIVÍDEO, em 1994 e 95 permitiram verificar os tipos de produção das unidades.
} 
antecedência, desenha-se um projeto do formato do programa. Sem um planejamento detalhado o material gravado geralmente fica em prateleiras, não há quem que se disponha a tentar uma edição.

Um outro aspecto a definir é a abordagem do tema. Um documentário sobre o processo de formação de favelas nas cidades pode ser preparado para um congresso de especialistas em sociologia, administração pública, planejamento urbano, ou pode ser dirigido para jovens alunos do $2^{\circ}$ grau. A escolha da abordagem, de como será tratado o tema, é fundamental para a execução das gravações, para a redação do texto de locução, para a edição, enfim, para toda a organização da produção do programa.

Já a produção de um vídeo didático exige um detalhamento de projeto mais preciso. Nesse caso será elaborado um roteiro com todas as cenas e falas, previamente planejadas segundo uma estratégia fundamentada em processos de ensino/aprendizado. É uma produção que permite a criação de cenas em estúdio, com atores, em salas de aula, laboratórios etc. Pode-se recorrer a um tratamento ficcional, mas o parâmetro será dado pela pedagogia e pela psicologia. Resgato aqui algumas colocações ${ }^{91}$ do Prof. Samuel Pfromm Netto, específicas para a discussão da Educação a Distância mas, também, apropriadas a estes comentários,

“O mundo inteiro já está saturado de saber que qualquer meio, para o ensino a distância, seja o vídeo, a TV, internet, qualquer coisa dessas, deve estar baseada num tripé que é o seguinte: primeiro o especialista do conteúdo, sem ele tudo desmorona, não adianta chamar só alguém que é da área, tem que ser o melhor, aquele que não deixa dúvida de conhecimento, você não pode mandar uma coisa para fora que alguém por aí vê e vai falar 'que besteira que esse cara falou!'. Quando o ensino vai para fora da sala de aula tem que ter muito cuidado com o que diz, o professor não está mais entre 4 paredes, só com seus alunos, onde algum deslize fica por ali mesmo e pode ser corrigido. Por isso o conteudista tem de ser o expert no assunto, o mais bem informado sobre as pesquisas na área.

O $2^{\circ}$ ponto de apoio desse tripé deve ser a participação de especialistas na produção audiovisual. Não dá mais para fazer 'cabeças falantes', não dá para ficar explicando oralmente coisas que a imagem coloca diretamente - então para explicar o 
funcionamento ou o mecanismo de uma máquina é só vê-la em ação. Tem de usar a imagem, usar o áudio e não deixar uma cabeça falante a falar sozinha.

O $3^{\circ}$ ponto de apoio do tripé são os especialistas no processo ensino/aprendizagem. Não se trata de mera transmissão de informações, o objetivo é a aprendizagem, e isso requer o conhecimento da psicologia, da pedagogia, que vão desenvolver técnicas e estratégias para garantir o aprendizado daquela matéria.

E tem outra coisa e esta vai no meio do tripé, e é ela que vai fazer o tripé existir - é um cifrão. Sem dinheiro não se faz um bom vídeo, uma boa televisão"

\subsection{2 - Planejamento}

O simplismo de grande parte da produção audiovisual da Universidade decorre principalmente da falta de conhecimento dos professores e pesquisadores sobre o processo de produção de vídeo e das particularidades da linguagem audiovisual. Não há propriamente uma concepção audiovisual, é comum produzir-se muitas imagens para depois serem anexadas a um texto de locução. Como são os principais solicitantes de serviços de vídeo, os docentes/pesquisadores necessitam de uma orientação anterior, de modo que as propostas de produção, desde o início, sejam organizadas segundo referências próprias do fazer audiovisual. Na organização do trabalho devem participar, com igual responsabilidade, saberes distintos, de um lado os docentes como especialistas no conteúdo e de outro, os funcionários como especialistas na produção de vídeo.

É uma exceção o funcionário ser chamado a opinar sobre o modo de produzir, em geral é apenas determinado um serviço, sem maiores considerações sobre os procedimentos e os objetivos da documentação. O funcionário, que na hierarquia da Universidade é subalterno ao professor, não tem um espaço reconhecido de tomada de decisões, seu conhecimento é subtraído pela hierarquia e ele deve apenas atender às solicitações. O que importa salientar é que o especialista em produção de vídeo é responsável não só por aspectos técnicos, de iluminação, de som etc, mas também, pela escolha de formas de narrativa, de organização das seqüências do roteiro, do tratamento 
visual e sonoro. É da sua competência decidir o como fazer, num sentido amplo conceitual, técnico e artístico.

\subsection{3 - Custos de produção}

Outra questão urgente para a produção de vídeo, já mencionada acima pelo Prof. Pfromm, é de custos. Na visão simplista basta a câmera, a fita e o funcionário, mas de fato, ocorrem despesas com materiais de consumo (fitas de vídeo para gravação e para edição, lâmpadas especiais, filtros e difusores de luz), com refeições e transporte, com serviços de terceiros (locutor, computação gráfica).

Os custos de produção serão implícitos ao projeto da produção. Se, por exemplo, planejamos 5 dias de gravações no centro da cidade para um documentário sobre cortiços, devemos incluir o custo das refeições da equipe. Com uma avaliação antecipada dessa questão, pelo funcionário técnico junto ao interessado na produção do vídeo, é possível fazer uma previsão de custos e, nos casos de pesquisas, incluí-la na solicitação de verbas normalmente feita às agências de fomento.

Nas produções que não são vinculadas a atividades de pesquisa, portanto sem recursos próprios, o problema é mais crítico. Os orçamentos das Unidades são, notoriamente, escassos e dificilmente podem arcar com as demandas específicas de uma produção. Como já comentamos, o FCEx, Fundo de Cultura e Extensão, da Pró-Reitoria de Cultura, e o SIAE, Sistema Integrado de Apoio ao Ensino, das Pró-Reitorias de Graduação e de Pós-Graduação, são duas fontes de recursos que, mesmo limitadas, vieram a favorecer a produção de vídeos na USP. Antes de surgirem tais iniciativas não havia meios de obter verbas para vídeos destinados ao ensino, à divulgação científica ou à difusão cultural. 


\subsection{4 - Distribuição e divulgação}

O processo de produção de vídeo não deve ser pensado isoladamente como um processo técnico que termina com uma cópia do programa editado. Há um antes e um depois que, se considerados e incentivados, darão um sentido maior a essa atividade.

Numa estratégia de comunicação, ampla e articulada, antes de iniciar uma produção busca-se levantar as demandas mais significativas por materiais audiovisuais, verifica-se quais as áreas em que se fazem mais necessários, localizam-se contextos onde serão melhor aproveitados, define-se um papel específico para o vídeo desempenhar.

A partir disso poderemos mobilizar os setores mais competentes da Universidade para colaborarem e participarem do processo. Tampouco, podemos permitir que uma produção termine com a copiagem de algumas fitas, uma para a biblioteca, outra para o professor.

Com uma produção planejada o programa finalizado poderá ter vida própria, ser distribuído a outras escolas, em São Paulo, em outros estados. Desde que apresente boa qualidade técnica e seu conteúdo independa de uma explicação anexa, um vídeo pode interessar a diversos grupos, não só de alunos e professores, mas outros pesquisadores, profissionais em busca de atualização, instituições culturais. A plena utilização do vídeo na Universidade envolverá, portanto, uma pesquisa, um planejamento, uma estratégia, que organize a demanda, que apoie a produção e que viabilize a difusão. 


\section{4 - O pensamento científico e o audiovisual}

A produção de vídeo no ambiente acadêmico se defronta com uma questão extremamente difícil, que é como integrar duas coisas tão essencialmente distintas - a ciência, com sua natureza vinculada ao processo da escrita e da leitura, e o vídeo, uma expressão que apela à imaginação, à criatividade, à simultaneidade de fluxos informativos, o visual, o sonoro, o textual. Este encontro, do vídeo com a ciência, de um professor universitário e um técnico de audiovisual discutindo a produção de um programa, traz implícita uma questão limite da contemporaneidade, a mudança de paradigma que as novas tecnologias da comunicação impõem aos processos do conhecimento. Conforme aponta Pierre Lévy,

"Novas maneiras de pensar e de conviver estão sendo elaboradas no mundo das telecomunicações e da informática. As relações entre os homens, o trabalho, a própria inteligência dependem, na verdade, da metamorfose incessante de dispositivos informacionais de todos os tipos. Escritura, leitura, visão, audição, criação, aprendizado são capturados por uma informática cada vez mais avançada. Não se pode mais conceber a pesquisa científica sem uma aparelhagem complexa que redistribui as antigas divisões entre experiência e teoria. Emerge, neste final de século XX, um conhecimento por simulação que os epistemologistas ainda não inventariaram.

...a escrita permite estender as capacidades da memória a curto prazo. É isto que explica sua eficácia como tecnologia intelectual. A informática da simulação e da visualização também é uma tecnologia intelectual, mas, ainda que ela estenda a 'memória de trabalho' biológica, funciona mais como um módulo externo e suplementar para a faculdade de imaginar." 92

A ciência e os cientistas estão formatados pelo processo da escritura. O desenvolvimento da escrita e das técnicas de impressão instrumentalizaram o Homem para um domínio do conhecimento, permitindo o acúmulo de informações, a permanência do conteúdo, a comparação, a atualização. A própria elaboração do pensamento científico foi estimulada a partir do momento em que o homem percebe seu pensar fora de si mesmo, colocado sobre um suporte visual, gráfico. Jack Goody considera que,

\footnotetext{
${ }^{92}$ Levy, Pierre. As Tecnologias da inteligência, São Paulo, Editora 34, 1993.
} 
“...a escrita, sobretudo a escrita alfabética, tornou possível uma maneira de examinar o discurso graças à forma semi-permanente que ela deu à mensagem oral. Esse meio de inspeção do discurso permitiu acrescentar o campo da atividade crítica, favoreceu a racionalidade, a atitude cética, o pensamento lógico ...Tornando possível o exame sucessivo de um conjunto de mensagens dispostas num período muito mais longo, a escrita favoreceu ao mesmo tempo o espírito crítico e a arte do comentário por um lado, o espírito ortodoxo e o respeito pelo livro do outro.

... não é por acaso que as etapas decisivas do desenvolvimento do que nós chamamos de 'ciência' seguiram por sua vez a introdução de uma mudança capital nas técnicas das comunicações: a escrita na Babilônia, o alfabeto na Grécia, a imprensa na Europa Ocidental."93

O pensamento científico nos coloca na condição de escritores e/ou leitores. É a forma escrita, por excelência, que confirma a validade da teoria, que apresenta sua fundamentação, que sustenta um novo passo na escalada do conhecimento. Esta ainda é a medida do mérito e da competência do cientista, as publicações realizadas. Mas, a partir das tecnologias da informática, a ciência vem transformando seus métodos de verificação e construção do conhecimento, o núcleo da atividade científica está se deslocando do raciocínio lógico para uma nova forma de conhecimento. Conforme Pierre Levy,

"Nossa capacidade de simular mentalmente os movimentos e reações possíveis do mundo exterior nos permite antecipar as conseqüências de nossos atos ... Parece mais plausível que as pessoas construam modelos mentais das situações ou dos objetos sobre os quais estão raciocinando, e depois explorem as diferentes possibilidades dentro dessas construções imaginárias. A simulação, que podemos considerar como uma imaginação auxiliada por computador, é portanto ao mesmo tempo uma ferramenta de ajuda ao raciocínio muito mais potente que a velha lógica formal que se baseava no alfabeto.

A teoria, sobretudo em sua versão mais formalizada, é uma forma de apresentação do saber, um modo de comunicação ou mesmo de persuasão. A simulação, pelo contrário, corresponde antes às etapas da atividade intelectual anteriores à exposição racional: a imaginação, a bricolagem mental, as tentativas e erros." 94

\footnotetext{
${ }^{93}$ Goody, Jack. Domestificação do pensamento selvagem, Lisboa, Editorial Presença, 1988; citado por Daniel, Taunay in Televisão e Comunicação Científica, dissertação de mestrado, Instituto de Artes, UNICAMP, Campinas, SP, 1995.

${ }^{94}$ Ibid.
} 
No dia a dia do mundo acadêmico, mesmo com a incorporação do computador, permanece o predomínio da formalização escrita. Porém, o que importa para a produção de vídeo sobre conhecimentos científicos são as características próprias das duas formas de expressão envolvidas, do audiovisual e da escrita, e principalmente, o comportamento do pesquisador diante de outra forma de comunicação que não aquela que ele conhece.

Taunay Daniel, em sua dissertação de mestrado, ${ }^{95}$ aponta uma distinção fundamental entre o vídeo e o texto impresso. O livro permite uma apreciação livre no tempo, lê-se quando se deseja, quantas páginas e no ritmo que se quiser, volta-se ao parágrafo anterior ou adianta-se até a conclusão, o fluxo da leitura independe de um tempo predeterminado. A situação de leitura também é livre, pode-se ler em casa, no trabalho, no ônibus, no consultório do dentista, o texto impresso é portátil e manuseável. No vídeo, e no cinema, há o tempo real da duração do que se vê, há um começo, meio e fim contínuo e, a obra foi elaborada considerando que o público a assistirá de uma só vez. No cinema esta é uma condição a priori da fruição do filme, ninguém assiste uma parte do filme hoje e deixa a outra para o dia seguinte, aliás ficamos chateados quando perdemos os primeiros minutos da projeção. No vídeo pode-se até considerar a possibilidade da interrupção ou voltar a fita e assistir outra vez, mas o tempo do programa será sempre o mesmo.

Essa questão do tempo é um ponto de conflito quando se propõe a colocação de um conteúdo científico sob a forma audiovisual. A apresentação de conhecimentos científicos na forma escrita, é linear e cumulativa, e segue uma racionalidade lógica, esse texto escrito não pode omitir etapas ou alterar a sua seqüência. Como o rigor científico exige o detalhamento dos cânones do saber, da fundamentação teórica, da metodologia, das premissas e conclusões, o texto correspondente ocupará dezenas ou centenas de páginas. Se tentarmos inserir um texto de uma pesquisa, com suas 100 páginas, como narração de um vídeo teremos um programa com a duração do tempo de sua leitura, será um tempo incompatível com o tempo audiovisual.

\footnotetext{
${ }^{95}$ Daniel, Taunay. Televisão e Comunicação Científica, Campinas, SP, Instituto de Artes, UNICAMP, 1995.
} 
$\mathrm{O}$ cinema descobriu, desde o final da primeira década do século $\mathrm{XX}$, com o recurso da montagem, o tempo cinematográfico, que não é o tempo real dos fatos, nem é o tempo de duração do filme, é um tempo representado. Estamos já muito acostumados com esse tempo, um filme nos mostra a história de várias gerações em 120 minutos, ou uma ação de poucos segundos é prolongada com sucessivos cortes das imagens detalhando os pormenores da cena. Se buscamos uma definição para o processo de passagem de um texto científico para um vídeo podemos pensar em uma "tradução", no sentido de uma recriação do original, ou, conforme o caso, o vídeo poderá ser "baseado em" tal original.

Ao cientista é muito difícil desprender-se de seu texto, é uma criação sua e, segundo sua concepção, todas as informações ali contidas são igualmente importantes. Mas o corte se impõe ou o vídeo terá algumas horas de duração.

Além da seleção do conteúdo, condição para a viabilidade da produção, outra questão relativa ao texto escrito exige nossa atenção. Na leitura de um livro nosso raciocínio se detém onde se faz necessária uma reflexão, avança conforme a nossa compreensão do texto o permite, dados anteriores podem ser checados, uma frase se sustenta sobre outra. O texto pode ser complexo, intrincado, cheio de referências a colocações já feitas, cabe ao leitor tecer o entendimento, manuseando o texto, relendo o não compreendido.

Na fruição do audiovisual, cinema ou vídeo, a priori, não há volta, cada frase deve conter informações numa quantidade apropriada, que não sature o público, qualquer perturbação na compreensão do conteúdo acarreta em perda de significado e a informação não captada é irrecuperável. A permanência do texto no audiovisual precisa da simplificação e da redundância, não podemos contar com a memória do público em associar uma frase aqui com outra lá do início do vídeo, pois há um fluxo extra textual, de imagens e sons que estão a exigir, também, sua atenção e compreensão.

Por estas questões o trabalho de produção de vídeo no ambiente das ciências será atravessado pela cisão, ainda existente, do pensamento científico, baseado na escrita, com o pensamento imagético, baseado na simultaneidade de informações. 


\section{6 - Conclusões}

No decorrer desta dissertação apresentei algumas das histórias de produção audiovisual na USP, muitas outras não foram comentadas - o Setor de Audiovisual do Hospital Universitário, o Centro de Apoio à Pesquisa em História da Faculdade de Filosofia, Letras e Ciências Humanas, o Laboratório Antropologia Visual também da FFLCH, as produções de vídeo realizadas no Instituto de Biologia.

Não pretendi um levantamento completo, mas procurei localizar ao longo da história desta Universidade a presença de intenções e realizações audiovisuais, todas essas experiências fornecem importantes subsídios à formulação de estratégias de fomento à produção audiovisual na Universidade. Nesse percurso algumas situações repetiam-se, fatores constantes marcavam presença, pretendo a seguir comentar tais situações e apresentar as conclusões desta dissertação.

\section{- Divulgação e/ou Comunicação}

O que é não só pertinente, mas urgente, é uma crítica ao conceito de divulgação científica. No sentido geral, como tenho visto na Universidade, em cursos específicos da área de comunicações ${ }^{96}$ e também em vídeos de divulgação, trata-se da transmissão de conhecimentos à população através da simplificação da linguagem, tornando o hermético texto científico acessível à compreensão leiga. Cabe estender essa questão, pois é subsídio às conclusões finais que apresentarei. Segundo as considerações da Profa. Dra. Cremilda Medina,

\footnotetext{
"Há uma distância histórica entre um projeto de divulgação ou difusão das informações produzidas na contemporaneidade e um projeto de comunicação social. No primeiro caso, o vetor informativo sai de acervos, fontes geradoras, centros de decisão que determinam os dados e significados que devem chegar aos receptores. No segundo, tanto ocorre uma oferta de informações quanto se expressam demandas coletivas, anônimas, ou grupais, descentralizadas dos grandes pólos de geração. Entre as estruturas difusionistas, com seus
}

\footnotetext{
${ }^{96}$ No caso, refiro-me ao curso de Divulgação Científica realizado em 1993, pelo Núcleo José Reis/ECA.
} 
instrumentos de divulgação, e os processos comunicativos, percebe-se, entre outros fatores, o papel mediador de agentes culturais que se consagraram, nas sociedades democráticas, como comunicadores." 97

Essa perspectiva aponta para uma efetiva integração da universidade à sociedade, pois esta participa do processo manifestando seus interesses, expressando o conhecimento que tem da sua própria realidade. Medina enfatiza a presença do comunicador nesse processo,

\begin{abstract}
"Se o comunicador social não invocar a poética, estará persistindo nos equívocos do signo difusionista, unidirecional, autoritário. Nenhum projeto de comunicação que se pretenda inovador, digno das expectativas sociais da transformação, pode se eximir da condição de uma oficina experimental. $\mathrm{O}$ eixo de tal oficina consiste na linguagem dialógica e na criação de narrativas democráticas a serviço da cidadania. Já o eixo tradicional da difusão se caracteriza pelas narrativas dirigidas, um vetor que sai das estruturas de poder para as consciências manipuláveis, concebendo o processo como mecanismo de causa e efeito, sujeito-objeto." 98
\end{abstract}

Ora, essa oficina requer um espaço amplo, dentro e fora da universidade, sem entraves políticos e administrativos. Aqui a atuação do comunicador requer autonomia, até porque a poesia é um movimento livre do pensamento, da imaginação. Essa é a meta. Caberá um esforço tenaz para alcançá-la.

Historicamente a USP não tem permitido espaços autônomos nem mesmo na tradição da difusão. Resgato uma passagem mencionada anteriormente, no processo da extinção do DCAS - Departamento de Cultura e Ação Social da Reitoria, na década de 50, sobre o papel da Divisão de Difusão Cultural,

\footnotetext{
“de fato, quando se estabelece que a Divisão entrará em entendimentos com as Faculdade e Institutos da Universidade de São Paulo para promover a difusão, o que se deve entender é que a iniciativa é da Divisão. Em vez de ser ela um órgão central auxiliar à disposição dos Institutos da Universidade, ela inverte a relação e passa a pedir ou a esperar que estes Institutos lhe tragam a sua contribuição. Mais ainda, se esses institutos se furtarem à colaboração, a Divisão poderá dar desenvolvimento ao seu magnífico programa de difusão cultural apelando ou comprando a colaboração de universidades nacionais e estrangeiras,
}

\footnotetext{
${ }^{97}$ Medina, Cremilda. O signo da relação, Política de Comunicação Social, CCS/USP, 2000.

${ }^{98} I d$.
} 
ou mesmo das entidades culturais em geral. Na universidade, cujo objetivo é a difusão cultural, um departamento especializado nessa função dá a entender que os demais órgãos, ou sejam os institutos universitários, não preenchem a contento essa função, ou então que não a devem preencher senão com o concurso daquele departamento, o qual, controlando parte dos recursos de que os institutos carecem, colocaria, na prática, os institutos em posição de subordinação" 99

Não se advoga, obviamente, uma independência de ações e propósitos. A questão é perceber quais as ações comunicacionais são necessárias sem estar limitado ao horizonte específico de apenas uma área científica, é estar sensível ao clamor além muros, ao que vem do outro lado. Então cabe aos comunicadores buscarem as demandas, proporem projetos e ações, e por extensão, considero tudo isso válido para os produtores de vídeo, fotógrafos, e outros profissionais que, trabalhando na Universidade, tem capacidade para desenvolver uma oficina.

O exemplo supra-citado, do DCAS dos anos 50 não representa uma coisa do passado, isolada. O depoimento de Cristiano Mascaro é eloqüente, em 14 anos na USP produziu uma exposição (por iniciativa própria) e foi criticado por sua independência. Em minha atividade como produtor de vídeo sempre me perguntam de qual professor é o vídeo que estou fazendo e não com qual professor estou trabalhando. Mesmo reconhecendo várias demandas de vídeos, demandas que são percebidas por não estar centrado na função acadêmica, não posso realizá-las sob pena de invadir um espaço privativo - o da iniciativa.

Portanto, uma das conclusões desta minha dissertação é que a falta de autonomia de ações, tem sido, ao longo da história da USP, para os que se dedicaram às atividades de produção audiovisual, uma força contraria à plena realização de suas vocações.

Um traço comum a vários dos casos relatados nesta dissertação é de terem sido realizações resultantes do empenho pessoal de algumas pessoas. O trabalho do Serviço de Documentação da Reitoria, nos anos 50 e 60, deve-se à dedicação de Guelfo Oscar Campiglia, os filmes documentários do IEB, em meados da década de 60, foi resultado do empenho de um grupo de cineastas que buscou apoio institucional da USP, outros projetos e realizações aconteceram e acontecem porque algumas pessoas investem seu

\footnotetext{
${ }^{99}$ Processo Rusp 10.839/55, pag. 11 e 12.
} 
tempo nesse trabalho e, regra geral, no impedimento, por qualquer motivo, de manterem tal dedicação, a experiência termina. A descontinuidade dos processos muitas vezes joga fora todo um investimento de recursos públicos feito em infra-estrutura e, também, perde-se o próprio saber gerado, não ocorre uma transferência daquele conhecimento desenvolvido para outras pessoas que poderiam dar seqüência à experiência. É justamente a continuidade das produções, o processo sistemático do pensar, do fazer e avaliar os vídeos que permitiria uma reflexão crítica e o surgimento de soluções para as dificuldades encontradas.

A USP não tem percebido, e não percebe por quê não valoriza, as experiências significativas de produção audiovisual que ocorreram e ocorrem no seu espaço, a ponto de, na inviabilidade da continuidade, acionar mecanismos que permitissem incorporar e disseminar os saberes ali desenvolvidos. Não existem tais mecanismos, não há estratégias de apoio emergencial que salvem experiências bem sucedidas. Elas ficam entregues à própria sorte. Assim, uma segunda conclusão é que a descontinuidade das práticas de produção audiovisual nesta Universidade tem gerado uma perda considerável de um conhecimento que é específico e que deixa de ser aproveitado por não existirem formas institucionalizadas de preservação e de disseminação desse conhecimento.

Por fim, todas as questões apontadas no decorrer desta dissertação devem buscar respostas a partir de uma visão global das possibilidades que a Universidade oferece. Ações isoladas correm o risco da incoerência. O Programa SIAE liberando verbas para a produção de materiais audiovisuais tem seu mérito, mas a USP deve prover os outros apoios necessários, cursos de capacitação, infra-estrutura técnica, inclusive, para que os recursos oferecidos por aquele Programa sejam aplicados com um melhor resultado. $\mathrm{O}$ UNIVÍDEO, que juntou de forma inédita docentes, pesquisadores, funcionários especializados e comunicadores para discutirem os problemas da produção e do uso do vídeo na Universidade, e que desenvolveu propostas articuladoras em várias questões do audiovisual, permaneceu como uma ação isolada, não obteve o apoio financeiro de que precisava e hoje subexiste em estado latente.

Sem verbas não se faz nada, mas sem planejamento a verba disponibilizada corre o risco de ser desperdiçada. Portanto, a uma ação global corresponderá uma política 
clara e duradoura, com o planejamento detalhado de projetos que se concretizem a partir de setores capacitados a sua implantação. Da integração de diversas ações resultará uma mudança de paradigma das políticas administrativas da Universidade. É uma política para o audiovisual que a USP deve buscar e esse é um caminho que poderá levá-la a um novo patamar nas relações intra-universidade e extra-universidade.

A produção de vídeos e de outros materiais audiovisuais (CD-ROM, WEB site) podem ser atividades de promoção da integração do trabalho de docentes, pesquisadores, funcionários especializados e alunos, mediante a sua valorização nos relatórios dos docentes e na avaliação funcional. Isso propiciaria uma interação da comunidade universitária e, sua plena realização exigiria também a ação conjunta de vários setores da instituição, criando, assim algo novo em seu ambiente tão marcado por isolamentos.

Os projetos e os instrumentos existem e até produzem, mas historicamente patinam em algumas engrenagens desajustadas da Universidade.

O vídeo é um meio para a Universidade estender-se à sociedade, uma forma de inserir-se no corpo social e de realizar uma reflexão em torno da tão comentada cultura televisiva contemporânea. 


\section{7-Bibliografia}

ANTUNHA, Heladio Cesar Gonçalves. Universidade de São Paulo, Fundação e Reforma, São Paulo, INEP/CRPE São Paulo, 1974.

ARISTARCO, Guido e Tereza. O Novo Mundo das Imagens Electrônicas, Lisboa, Edições 70, 1990.

BERNARDET, Jean-Claude e Alcides Freire RAMOS. Cinema e História do Brasil, São Paulo, Editora Contexto, 1998.

DANIEL, Taunay. Televisão e Comunicação Científica, Dissertação de Mestrado, Campinas, SP, Instituto de Artes/UNICAMP, 1995.

CAMPOS, Ernesto de Souza. História da Universidade de São Paulo, São Paulo, USP, 1954.

Temas Universitários, São Paulo, USP, 1952.

CAVALLETTI, Mauro. Expressão Audiovisual, Dissertação de Mestrado, São Paulo, ECA/USP, 1999.

FARKAS, Thomaz Jorge. Cinema Documentário: um Método de Trabalho, Tese de Doutorado, São Paulo, ECA/USP, 1972.

FRANCO, Marília da Silva. Escola Audiovisual, Tese de Doutorado, São Paulo, ECA/USP, 1987.

GOSCIOLA, Vicente. Nos Bastidores da Sala de Aula: a Videogravação no Processo de Ensino-aprendizagem, São Paulo, Dissertação de Mestrado, ECA/USP, 1995.

GUIDI, Mario. De Altamira a Palo Alto, Tese de Livre Docência, São Paulo, ECA/USP, 1991.

HOINEFF, Nelson. TV em Expansão: Novas Tecnologias, Segmentação, Abrangência e Acesso na TV Moderna, Rio de Janeiro, Editora Record, 1991.

KUNSCH, Margarida M. Krohling. Universidade e Comunicação na Edificação da Sociedade, São Paulo, Editora Loyola, 1992.

LEITE, Rogério C. Cerqueira. As Sete Pragas da Universidade Brasileira, São Paulo, Editora Duas Cidades, 1980.

LEVY, Pierre. As Tecnologias da Inteligência, Rio de Janeiro, Editora 34, 1993.

MACHADO, Arlindo. A Arte do Vídeo, São Paulo, Editora Brasiliense, 1988.

MACHADO, Arlindo. O Diálogo entre Cinema e Vídeo, in_Revista USP, n. 19, São Paulo, set/nov 93. 
MARTIRANI, Laura. Vídeo, Cultura e Linguagem, Tese de Doutorado, São Paulo, FE/USP, 1997.

MEDINA, Cremilda. O Signo da Relação, São Paulo, CCS/USP, 2000.

NETTO, Samuel Pfromm. Telas que Ensinam, Editora Alínea, Campinas, SP, 1998.

PARRA, Nélio. Recursos Audiovisuais e a Renovação Didática, Tese de Doutorado, São Paulo, FE/USP, 1972.

PRETTO, Nelson De Luca. A Universidade e o Mundo da Comunicação, Tese de Doutorado, São Paulo, ECA/USP, 1994.

SANTOS, Maria Cecília Loschiavo dos. USP: Alma Mater Paulista, São Paulo, Editora da USP, 1998.

SOUZA, Maria Adélia Aparecida de, e equipe. O Espaço da USP: Presente e Futuro, São Paulo, USP, 1985.

TOFFLER, Alvin. Powershift: as Mudanças do Poder, Rio de Janeiro, Editora Record, 1990.

WASHINGTON, Luís. Universidade de São Paulo, São Paulo, USP, 1950.

WATTS, Harris. On Camera, São Paulo, Summus Editorial, 1984.

\section{OUTROS DOCUMENTOS}

Anteprojeto TV-USP, elaborado pelos professores Carlos Augusto Machado Calil (coordenador), Dr. Mário Guidi, Ricardo Herling, Roberto Elizabetsky, Suely Pontes Valente, ECA/USP, 1989.

Arquivo da Secretaria Geral da Universidade de São Paulo, processos RUSP no. $10.839 / 55,15.625 / 63,17.534 / 64$.

Consolidação dos Estatutos da Universidade de São Paulo, USP, 1964.

Decreto no. 6.238 de 25 de janeiro de 1934, de Fundação da Universidade de São Paulo, 1934.

Educação Continuada à Distância na Universidade de São Paulo, CECAE/USP, 1995.

Estatuto e Regimento Geral da USP, Departamento de Jornalismo, ECA/USP, 1972.

Estatuto da Universidade de São Paulo, conforme Resolução no. 3461, de 07 de outubro de 1988, e complementações, USP, 1999. 
Resoluções 4206/95 e 4259/96, normas do FCEx, Fundo de Cultura e Extensão da PróReitoria de Cultura e Extensão da USP.

Regimento Geral da Universidade de São Paulo, conforme Resolução no. 3745, de 19 de outubro de 1990, e complementações, USP, 1998.

USP - Universidade de São Paulo, Secretaria da Ciência, Tecnologia e Desenvolvimento Econômico do Estado de São Paulo, 1990.

\section{DEPOIMENTOS}

Prof. Dr. Claudio Zaki Dib

Prof. Dr. Marcelo Tassara

Prof. Dr. Mário Arturo Alberto Guidi

Prof. Dr. Samuel Pfromm Netto

Cristiano Mascaro

Chicrala Haidar

Sergio Muniz

Oscar Campiglia 
$\underline{\text { ANEXO I - Decreto de Fundação da Universidade de São Paulo }}$

(cópia parcial do texto do documento) 
DECRETO N. 6.283 , DE 25 DE JANEIRO DE 1934.

Cria a Universidade de São Paulo e dả outras providências.

"O doutor Armando de Salles Oliveira, Interventor Federal do Estado de São Paulo, usando das atribuiçôes que the confere o decreto federal $\mathrm{n}$. $^{\circ} 19.398$, de 11 de novembro de 1930; e

considerando que a organizaçâo e o desenvolvimento da cultura filosófica, científica, literária e artistica constituem as bases em que se assentam a liberdade e a grandeza de um povo;

considerando que sómente por seus institutos de investigaçâo cientifica de altos estudos, de cultura livre, desinteressada, pode uma naçāo moderna adquirir a consciência de si mesma, de seus recursos, de seus destinos;

considerando que a formaçăo das classes dirigentes, mòrmente em paises de populaçōes heterogêneas e costumes diversos, está condicionada a organizaçāo de um aparêlho cultural e universitário, que ofereça oportunidade a todos e processe a seleção dos mais capazes:

considerando que em face do grau de cultura já atingido pelo Estado de Săo Paulo, com Escolas, Faculdades, Institutos, de formaçáo profíssional e de investigaçấo cientifica, é necessário e oportuno elevar a um nivel universitário a preparaçāo do homem, do profissional e do cidadāo,

Decreta:

TituLo I

\section{DA UNIVERSIDADE DE SÃO PAULO}

Art. $10^{\circ}-$

Fica criada, com sede nesta Capital, a Universidade de Sâo Paulo.

Art. $2 .^{\circ}$ - São fins da Universidade:

a) promover, pela pesquisa, o progresso da ciência;

b) transmitir, pelo ensino, conhecimentos que enriqueçam ou desenvolvam o espirito ou sejam úteis à vida;

c) formar especialistas em todos os ramos de cultura, e técnicos e profissionais em tôdas as profissỏes de base cientifica ou artistica;

d) realizar a obra social de vulgarizaçăo das ciências, das letras e das artes, por meio de cursos sintéticos, conferéncias, palestras, difusão pelo rádio, filmes científicos e congêneres. 


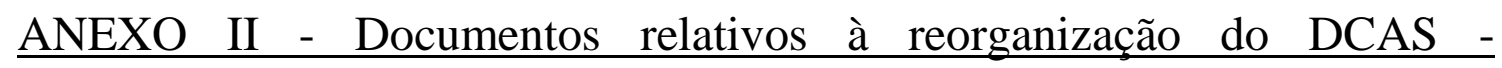

Departamento de Cultura e Ação Social

a) Ficha de transferência de patrimônio da Divisão de Rádio do DCAS para o Instituto de Eletrotécnica, 05/07/1956.

b) Minuta de Portaria relativa à reorganização de setores remanescentes do DCAS, 08/08/1960.

c) Ofício da Divisão de Documentação Técnica e Científica da Reitoria com indicaçào de chefias, 12/12/1960. 


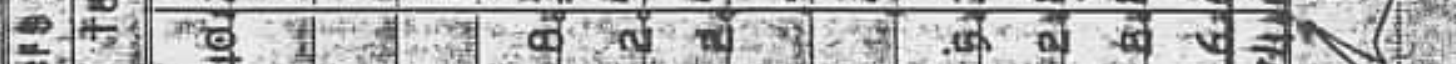

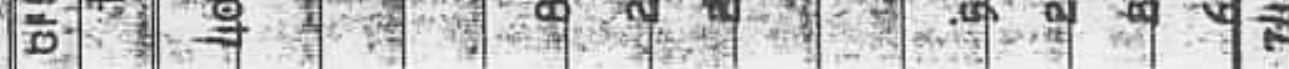
噌

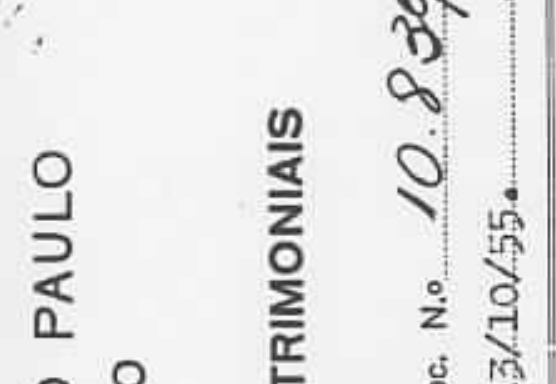

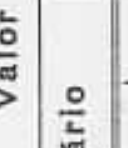

워

$\frac{3}{5}$ के वै ती in है ㄷำ व ?

凹造 造

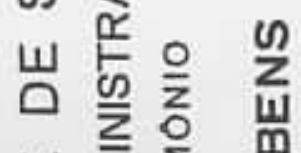

W

造它崖

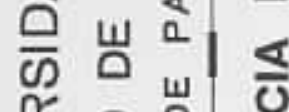

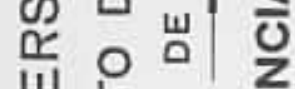

$\geq \sum_{0} 0$ 嵌

$\frac{\pi}{1}$

つ $\sum_{\leftarrow}^{\infty} \frac{\infty}{0}$

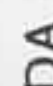

$\varangle \frac{5}{\alpha}$

$\leqslant$ 璐 妥

뭉

늠

-

U

$\frac{1}{2}$

(1)

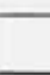

4

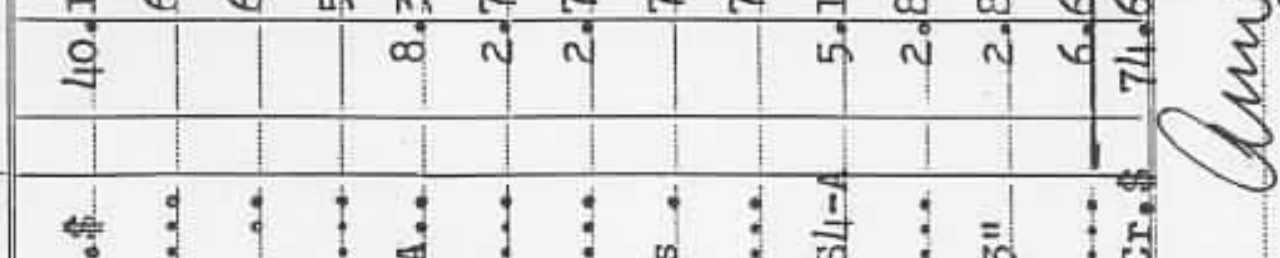

of $z$

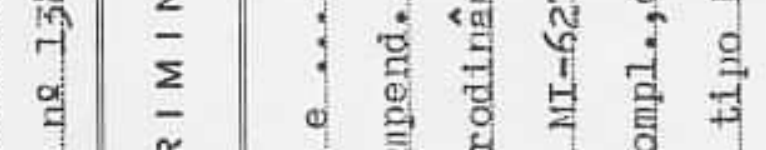

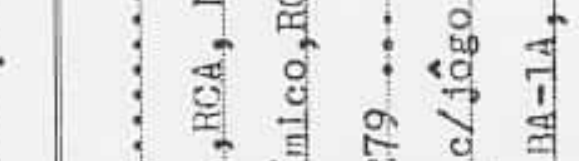

สำ 0

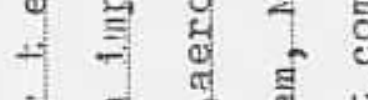

+ : $\bar{M}$

: : क्षे है

च वे ले बूँ

वे? 


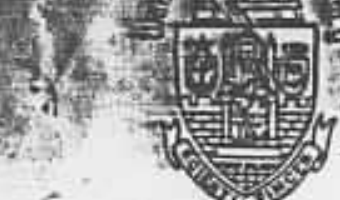

REITORIA DA UNIVERSIDADE

DE sAO PAULO

N.0. P. $10.839 / 55$

$\underline{P} \underline{0} \underline{R} \underline{\underline{T}} \underline{\mathrm{R}} \underline{\mathrm{I}} \underline{\mathrm{A}} \underline{\mathrm{N}} \underline{\underline{0}}$

O REITOR DA UNTVERSIDADE DE SÃO PAULO, $u-$ sando das atribuições que the são conferıdas por le1, devidamente autorizado pelo Senhor Governador do Estado, e consoante o decidido pelo Colendo Conselho Universitário, em Sessão de 8 de agôsto de 1.960 ,

R E S O L V E :

Artigo 1e - A Secretaria Geral, além da Secção de Expediente (artigo 26 do R.I. da R.U.S.P.), com preende :
a) Divisão de Difusão Cultural;
b) Divisão de Documentação Técnico-CientI flca;
c) Divisāo Bibliográfica.

Artigo 20 - Compete à Divisão de Difusäo Cultural promover e incentivar, mediante autorização supe rior, cursos, conferências, publicações e quaisquer ou tras atividades de caráter cultural destinadas à divulgaçäo dos conhecimentos e progressos verificados no setor da cultura, ciências, letras e artes, bem como secreta riar a Comissäo de Bolsas.

Artigo $3 e$ - A Divisão de Difusão Cultural compreende :

a) Secção de Cursos de Extensão Universitária;

b) Secção de Divulgação e Publicaçōes; e

c) Secção de Bolsas de Estudos e Intercâm bio Cultural. 
MEITORIA DA UNIVERSIDADE

São Paulo, 12 de dezembro de 1960.

DE SXO PAULO

RUA HELVETIA, BO

TEL: O2-TBOI

$\frac{\mathrm{DD}-242 / 60}{\mathrm{GOC} / \mathrm{LHC}}$

Senhor Secretário Geral:

Tenho a satisfação de indicar para responder pelas Chefias da Divisão de Documentação Técnica e Cientffica os seguintes funcionários:

1) Seç̧ão de Cinema:

Sta. Marine Cezar Marcondes Cabral.

2) Seç̧ão de Informações Documentá ries:

Sra. Laura Menezes de Castro.

3) Seç̧ãc de Fotodocumentação:

Sra. Maria Cordaro de Campos Salles.

WOTA: Estas indicações em parte,pre valecem atß̂́ a restruturação geral da Divisão.

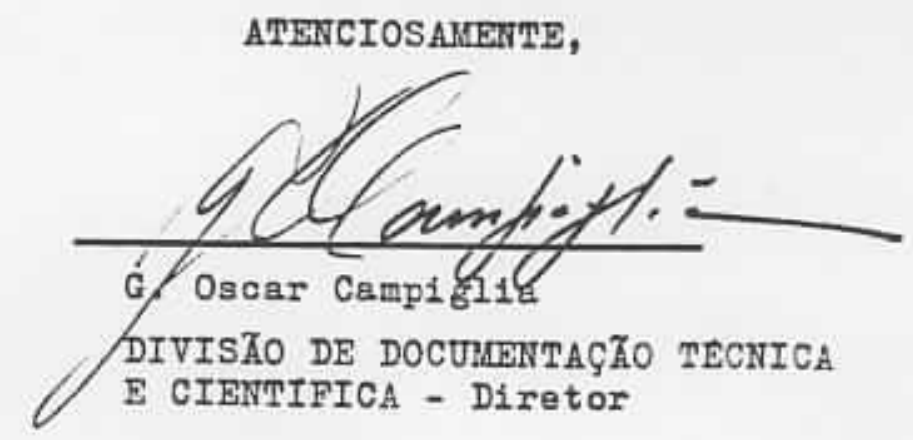

Ao Ilmo. Sr.

Dr. Júlio Mário Stamato

DD. Secretário Geral da

Reitoria da Universidade de São Paulo

CAPITAL 


\section{$\underline{\text { ANEXO III - Documentos relativos à TV Educativa USP/Ford Foundation }}$}

a) Correspondência da Ford Fundation ao Reitor da USP, Dr. Luis Antonio da Gama e Silva, 20/05/1964.

b) Página 01 do projeto da TV Educativa elaborado pelo Dr. Laerte Ramos de Carvalho, diretor do CRPE - Centro Regional de Pesquisas Educacionais, 21/07/1964.

c) Ofício do diretor da ECC - Escola de Comunicações Culturais, Prof. Julio Garcia Morejón, ao Reitor, Dr. Luis Antonio da Gama e Silva, solicitando a incorporação da TV Educativa ao patrimônio da ECC, 25/11/1966.

d) Relatório da Comissão de Televisão Educativa da USP, 07/12/1966.

e) Relação parcial dos equipamentos adquiridos para a TV Educativa da USP. 


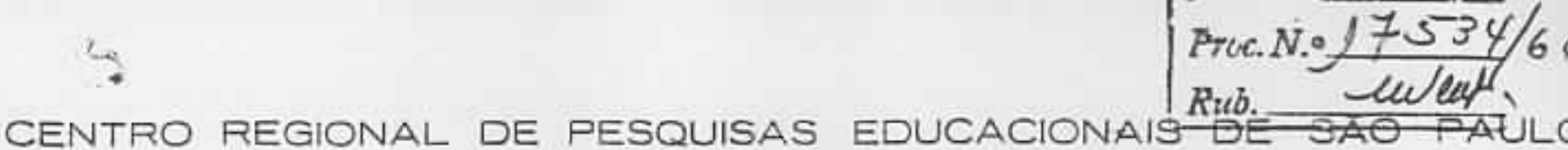
CIDADE UINIVERSITÁAIA

Fôlha de informaçōes rubricada sob n."

do Processo Adm. - Técn. - Pess. n. ${ }^{0}$

(a)

He $3021 / 64$

Os estudes referentes à instalação de TV en circuito fechadu na USP iniciaram-se con e sucinte esboço (Anex॰ ne I), de un documento preparado para a Ferd Foundation e apresentado a lagní fice Reitor, Prof. Dr. Luiz Antônio da Gana. Silva, numa rourião ctalizada no día 12 de agôsto do 1963 a que conpareceran of Srs. Representantes da Ford Foundation Janes W.Arnsey e Georgo F.Lite tle, - Prof. Jøhn F.Baxter, da Universidade de Flórila, B.U.A. • - abaix assinado, Diretor de CRPE de São Paulo.

Hesta reunião, - Kagnifico Reitor designou-me, para roalizar ostudos o manter contatos com a Ford Foundation, tendo on riata a efetivação das provilências indispensáveis à instalação es TV odu cativa en circuito fechado. 0 decumento original foi reelaborado, tendo en viata lefinir melher $\bullet$ papal que a TVE poderá repreaen $\operatorname{tar}$ na USP. (Anexo II) Proneveran-we, então, várias reuniõo co diferentes brupos de professôres. Para estas reuniões foi prepara do un decumento especial (Anexo no 3) e delas resultou um prineiro relatório (Anexo ne 4). Fil reuniäo con es Representantea la Ford Foundation, George little John Baxter, nов disa 8 e 10 de julho do corrente ano, ficou resolvido que no ano de 1965 sorian ninistrades os cursos de Metodelogia Geral. de Ensine, Peicologia ¿a Educkção, Administração Escolar e química.

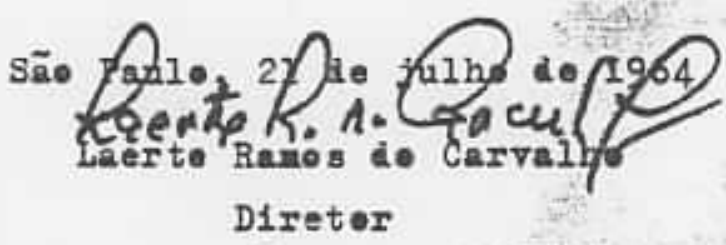




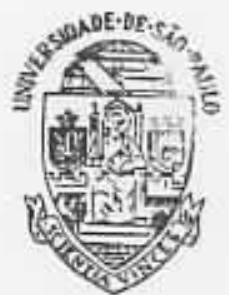

Cldade Univerniuris

Armando de Sallen Oliveira

Sato Pauis - Brasil

$27 / 66$

$\mathrm{eCO} / \mathrm{mo}$

Magnifico $R_{e}$ itor:

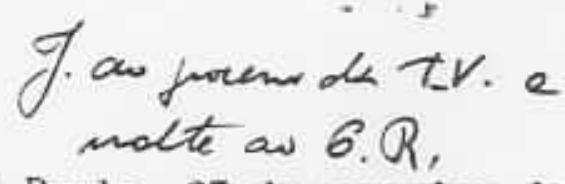
Säo Paulo, 25 de novembro de 1966

Tenho a honra de solicitar de Vossa Magnificencia pronunciamento sôbre o problema de instalaçāo e funcionamento da Televisāo Educativa da Universidade de São Paulo, com vistas ae ime diato funcionamento da mesma.

$$
\text { al }+8-\sqrt{x-1}-66 \text {. }
$$

aparel hos, dosmsiderando que há algum tempo encontram-se os aparelhos, dosmais modernos no genero, em condiçôs de serem aproveitados em benefício da nossa Universidade, na espectativa da che gada de um aparelho de micro-ondas que permita a distribuiçāo da imagem pelos diferentes monitores a serem instalados em pentos estratégicos da Cidade Universitária;

considerando que com a criação da Escola de Comunicaçōes Culturais da U.S.P., que deverá instalar muito breve seu Curso de Rádio e Televisāo, o equipamento já existente da Televisāo, doado pela Fundaçăo Ford, prestará relevantes serviços aos alunos do referido Curso, os quais terāo imensas facilidades para as suas práticas escolares;

considerando que o plano inicial de atividades da TV Educativa nāo ficará prejudicado, pois a mesma poderá desenvolver de imediato amplo programa didático, tanto para os futuros Cur sos Básicos da Universidade como para Cursos de outra espécie e pa lestras de divulgaçäo cultural e artísitca;

considerando que um aparelhamento de tão alto cus to e tāo delicado poderá sofrer sérios prejuízos se nāo för utilizado ou estiver em desuso durante alguns meses, pelo fenomeno de estrago próprio de todo ou quase todo o material eletrónico; considerando que foi reservada a ala direita do 22 andar do Prédio da USP para as instalaçóes provisórias da Escola de Comunicaçōes Culturais, cujos projetos de adaptaçäo já foram feitos pelo Funda para a Construçäo da Cidade Universitária, permito-me, amparado nestas consideraçöes, solici tar a Vossa Magnificencia se digne determinar a incorporaçăo da TV Educativa, propriedade da Universidade de São Paulo, a patrimônio da Escola de Comunicaçōes Culturais, sem prejuízo das atividades do centes planejadas para a referida TV e de acordo com os planos estabelecidos com a Fundaçäo Ford.

$$
\text { Ao ensejo, renovo a Vossa Magnificencia protestos }
$$
de minha mais alta estima e consideraçäo.

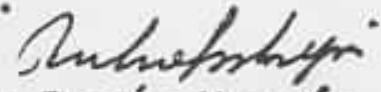

Julio García Morejón - Diretor

A Sua Magnificencia o Senhor

Prof. Dr. LUIS ANTÔNIO DA GAMA E SILVA

Magnifico Reitor da Universidade de Säo Paulo.- 


\section{PATIO}

0 presente relatório refere-se à orimem, desenvolvimento e estado atual do nrojeto de oriação de um Serviço de Televisão Educativa, na Universidade ie São Paulo, resumindo e ampliando o contevido de relatórios anteriores, preparados por esta Comissão e que constam do Processo sồre o Senvico de Televisẽo Tducativa arquivado no Centro Regional de Eesa - sas Bduoncionais Prof. Queiroz Filho.

E composto das seguintes partes: I. Objetiros do Serviço de Televieg̃o Educativa. II. Orirem e desenvolvimento do projeto. III. Pessoal e matērial. IT. Problemas lisados A. mudanca para o ediffoio da Reitoria. $\nabla$. Providências necessfriss.

\section{ORJETITOS DO SERVICO DE THITITST̃O EIDUCATITA}

Os objetivos do Serviço de Televisão Educativa da Universidade A.e Sĩo Paulo sño os seguintes:

(A) Atender à.s necessidades de ensino dos oursos da Universiinde -- inicialmente, cumeng te Ticenciature (Dgicolomin Bducrcional, Administracão Jsooler e Hetodolopis) e ie fuímioe, de Frouldede de F4.Losofia, Oiências a Letras, e, mais tarî̀, Cursos Básicos.

(B) Produzir nronramas en videotape, sồre aseuntos educativos, dientificos e oulturais, Jara uso da Tniversidede, do Instituto Nacional de Bstulos Pequágionos e do Ministério de Educecão e Cultura e de outras instituicões, em transmissões por circuito fechacio de sua própria estação, ou por circuito aberto, através de programes de estaçöes educativas ou comeroiais.

(c) Manter programas de intercâmbio com outras Universidades e Anstituioões nocionais e estrangeires que trabalhom em telovisão eduativa.

(D) Trangmitin em circuito aberto, desde mue obtida a concessão de canal para tanto, programas de onsater cultural, oivico e educativo.

(F) Converter-se, no futuro, em centro de troinamento para espec๋qlistas em televisão educativa.

\section{ORICIISS E DESENTOLVINTEMO}

\section{Entencimentod inioiais}




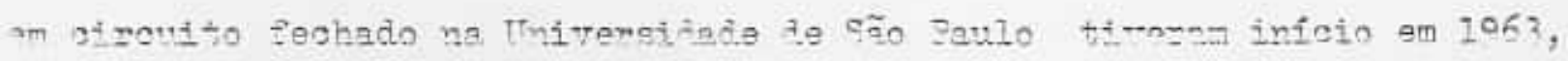

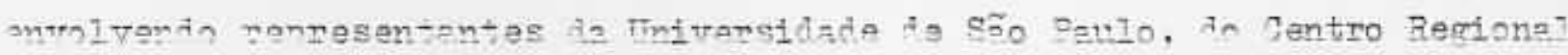

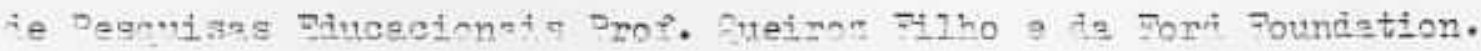

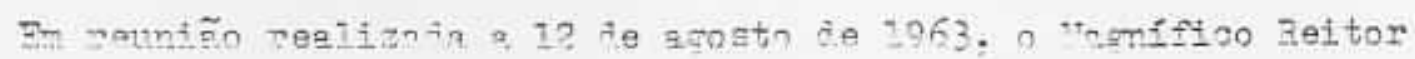
Aa TEP. Dr. Tuie intônio da Gara e Silvn, Aegimoun Dr. Laerte Bamos de

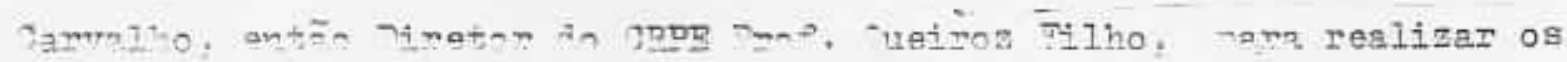

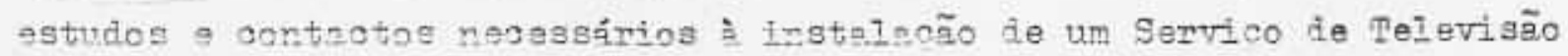
Daucetiva.

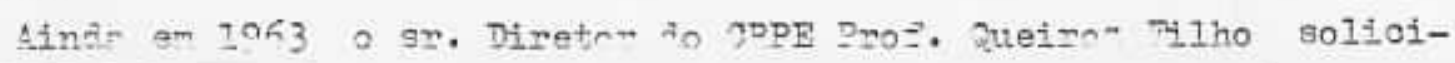

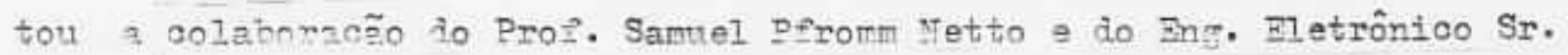

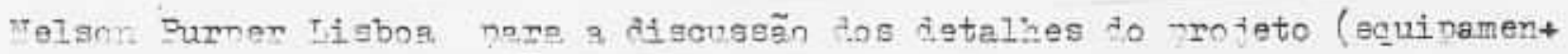

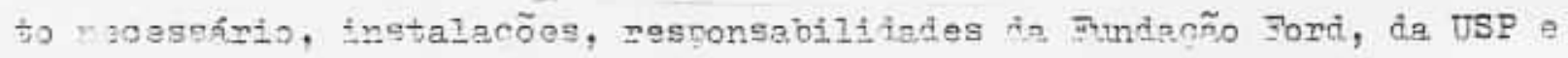
is CDDE Prof. Gueiroz Filho etc) juntamente com os Prof.s Ceorge F. Ifttle, de Fundacãn Ford, Br. Kenneth Thrietiansen, Diretor da Televisão

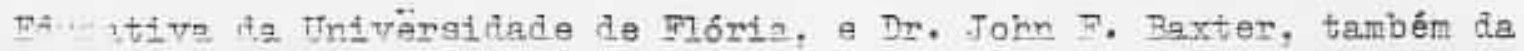
Maiverstiade A.e Flórida.

Os resultados de tais estuíos e mtenAi-entos Pnorem gnraminhedos no Tamilico Reitor a 7 de agosto de 1954 .

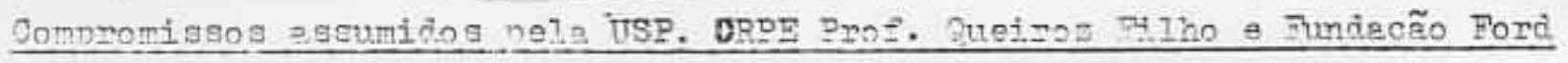

De noôndo anth o alle consta do rrocesso da USD ne 17534/64 (fls. 22. $21=25)$, abberia 3 Funiacão Ford o forncecimento de aucillio finan-

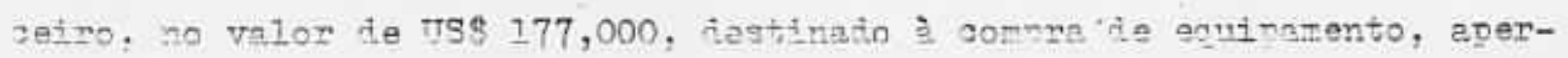
Eefcosmento de pessoel nos Eatados Thitios fa Ambmion do tonte e assistên-

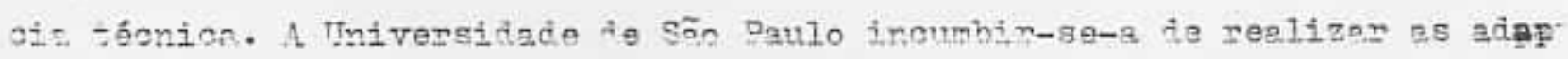

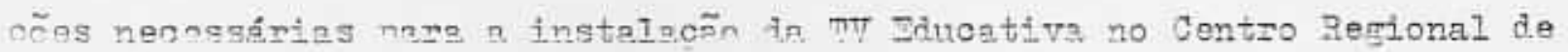
Descuiras पtuoroionais Prof. Queizos FHIho. ficando tambér a geu oargo 0 estahelecirento da rêde ie transmitasão e recenção e a colaboração de profe sôres a assistentes da Iniversidare. O Centro Rerional de Pesquisas Educacionaís ceiería parte dq f́rea entêo ocupada pelo Servico de Recursos AudioTisunis, para a instalação de estudio, esoritórios o outras dependências, contribuiria Ifnanceiramente tanto paro a insteleção da. TV educativa como nero o contrato e pagamento de pessosi.

Convém Iembrar que a locnlizacño ia TT educativa no Centro Regional ie Poscuises Ėuonoioneijs imnliosva na utilizacão dos vários servicos de zte to jispurhe êste Centro - Jesenho e Ietragen, gácuing "hot press" ie titulagem pazn cine e tv, ravarão e fllmagem cinemetoprófica, laboratório lotográficoo, seação de Eudio etc. - e do peseozl to Serviço de Recursos Autiovisuais. Tencio em vista o projeto de Tit equcative, a Direção do CRPE Prof. Queiroz Bilho valeu-se da oferta de bolsas de estudo para especiali\#aça nos Estados Unidos D roporoioneda pela AID/AIienç para o Progresso, enviando a Mahigan State Univergity três funcionários do Servico de Reour- 


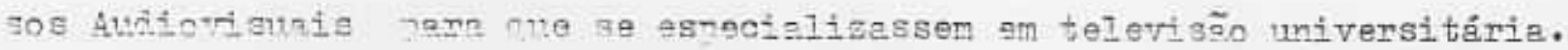
Tais pessogs -- A.I. Luiz Antonio Souso Iine de Vacedo, Profa. Ecyra Toledo a sr. Tinohelido Anrelo ie Taprolho - conoleteram sous estudos naouela Universiliade e recreggavem 30 Arast am 1055 e Iokh.

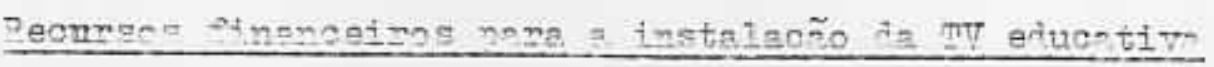

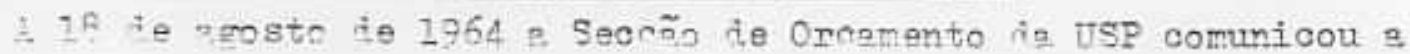
notacãc de comnomisso in thiversicate no montente de Or\& 21.140.000 nare inolusño ?o opcamento do exercicio de 1065 , a fil de atender ès despesas com a instalacão da TV Educ:tiva.

A 22 de setembrc de 1964 , a Ford. Founcation informou o Vegnifico Veitor ie concessão, pelo mrazo ie trîs anos (isto $\hat{e}$, sté 22 de setembro Ie 1967) Ae euritto no valor de US "177,000, "zare o agtrbelecimento de um sistaha te telgvigẽo em circuito techedo pare uso em ensino direto ne Univerginaç".

A 13 de moin de 1065. O ar. Diretor do CRPI Irof. Queiroz Filho, Inf meve que o IIIPP autorizare a degnese de Or\$ 16.465 .139 para a instale-

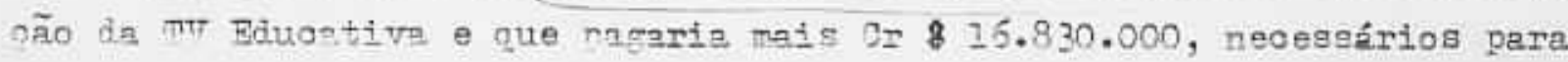
modiffcar o ststema de onergile elétrice do gRPD, 3 fim de atenter às neeessidedeg In tv educetive, totalizando asses dues desnesas o talor de Or\$ 33.295.139. Os trebalhos necessários foram realizados nelo Fundo de Donetruño de Cidade Univergitárí.

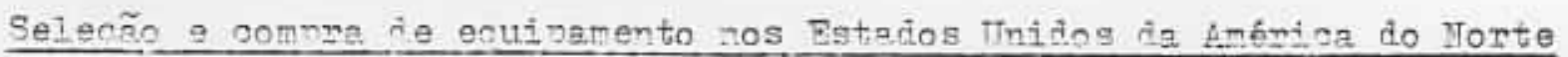

Dos sentegtos menticios entre os renpegententes Ford Foundiation

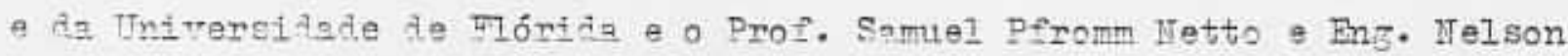

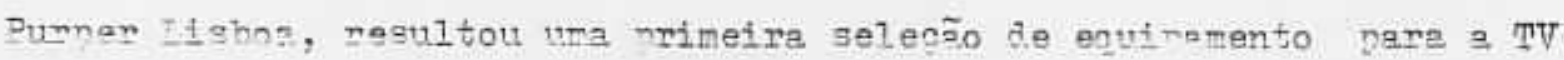
educstit3. Im novembro ie 1954 , o Enr. Iisoos sequiu nare os Estados Unidos, a Aim de ultinar providências a respeito da compra Aêsse equipemento e completar os entendimentos faitos, sssim como exteriar em estacõor de teleVisão de univensidades norte-ameriognas. \& selecõn do aruínamento $\theta$ as tronsacöss de on-nge sontaram com a nartioinanã i.o In. Wenneth Christiansen Diretor da TU Bducativa da Universidade de Flórida. Tizarens ie esturin e treinamento

Im janeiro de 1965, autorizadoe pelo sr. Diretor do CRPE Prof. queiros Fitho, os orofs. Samuel Peromm Hetto e Itélio Parra seguiram para. os Estecios Unicios da América do Forte, a filtr de se inteirarem do aistema. de funcionamento, oroducão e coordenaç̃o de gervicos universitúrios de tv edincetiva. Totamente com a coleboraç̃o do Diretor de TV Dducative da UniTersidade de 퀴órida, foi nossivel, naquela ocasiaó, definir mais preoisamente os objetitos e os passos a serem dados para a imnlantaça da televisão educative ne Universidade de São Paulo.

Preneracão ie aulzs nara televisão 


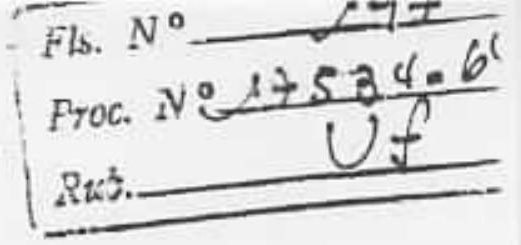

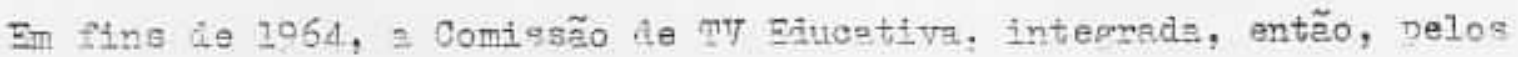
geus atuais memorog a maig o Dr. Iufz Antonio Sousa Time de Hacedo a o Prof. Paulo Borros Teixieire, iniciou contaotos cott os Frofessôres Amrigo Leonardo Anrelint, de Psicologia Fucacional, Fmesto Gisbreoht, de eufmiar Améli: Amaricano Domingues de Cestro, Ae Hatodoloric, e Tośb Querino Pibeiro, de Administraç̃o Escolar, pars toner as primeiras decisões a respeito jos curgos por televisão -- horários de produç̃o e transmissão, roteiros, téonica de aula p or tv etc. Almumes aulas chegeram a ser esbocadas, interrompenio-se essa atividade poraue o seu prossegrimento dependis Ae equipamento e instalacões.

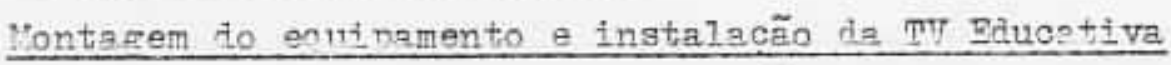

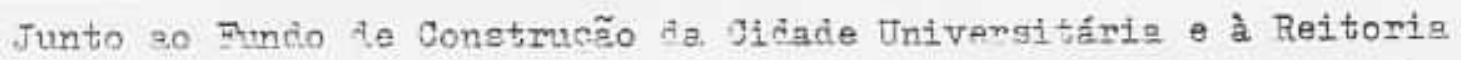
ie US?, Eng. Telson Purner Lisbos trebalhou no sentido de se conoretizarem as obres necessérias no CRPE Prof. Aueiros Fitho para a instalacão e funcionamento da IV Eduoativa. Tal instalação, de acôrỉo com os entendimer a mantidios com a. Fordi Foundation e Os assessôres norte-amerionos do rojeto, seria em perte das dependêncies em cue funoiona o Servico de Remursos Audiovisueis do CRPE Prof. Queiroz Filho. 0 sr. Nelson P. Lisboa tratou, einda, junto a Reitorie e ao Fundo de Construcão, das providências para a compra ie cebos onexiais e monitores, necessários para a traasmissä. dos nropramas. Obtide vorbe do IIIEP, formm executades, a partir de outubrc ie 1965 , a obres nara 3. instalacẽo te televisã no CRPE Prof. Queiroz Fitho. Joncluidas essas obras no conrente ano, nrocedeu-ge en seguide ao afuste e montezem do equinamento, pacebicio on novemiro de 1965 .

Sigteme de trangmissão

Previsto oximinalmente como sistema de asbos coaxiais subterrâneos, o sisteme de transmissão de tv ne Oldade Universitária foi, posteriormente, por. sugestäo do sr. Bng. Nelson Pumper Iisbo2, modificado pars miarooniss. A Tniversidade conta, jó, gom os monitores que deverão ser instalajos on salas de aule e con obbos coexiais jere distribuição intenna nos ediffcios, was a compra do sistema de mioroondas implica em novas deepesas, nẽo previstas nos plenos originais. Bm virtude disso, a Universidade de São Paulo consultou a Fundacão Ford. sôbre = nossibilidade de usa: papte do saldo tc loacão recebłda pare tal fim. A resposta da Fundação Fౌord 201 negativa.

De ncôrdo com os entrilimentne rentilos ne Untrersilace, os ediźcios inictelmente destirndos a peceber monitores serism a CRPI, o Conjunto iss evimioas e O Dafício Historie $\theta$ Geomrifia.

Ante-projeto de oxiecão do Servico de Televiaño Eduostiva

Durente o primeiro semestre de 1966 , a Comissão de Televisão Eadu- 


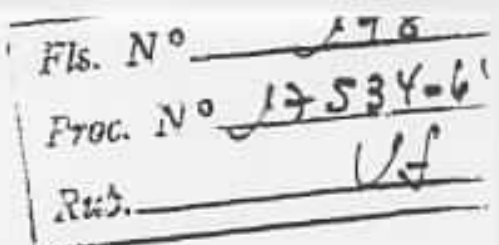

getivo reuniu-ge vémias veges con o Iiretor co ORPE Proż. Gueiroz Filiho, Dr. Jerlos Corres Nascaro. nara discutin providênci.ag a serem adotredes p estucien os planos de ormanizacão do Serviço de Tit. Thes reuniões con-

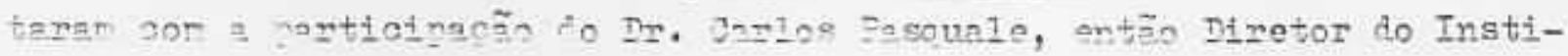

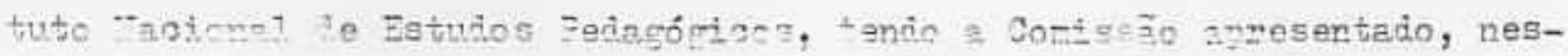

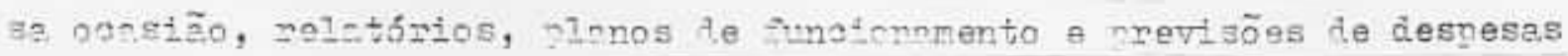
com pessogl a meteriel. Foi ginda roelizads una veuniso cia quel partici-

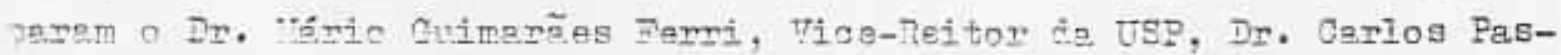
guale, Direton to IHEP, Dr. Carlos Dorrea Nesenno, Diretor do CRPE, e os membros is Comissão de TV, nare rever os têrmos do acôrcio original entre a Universidede, O CRPE a a Iundaç̃o प̄ord e estudar um ante-projeto de gonvênio prensrsio pelo sr. Iiretor co CRPs.

- Completecis as obres de instelacõo e a testacer to equipamento, a Comissão de TY Educetive prerlarou, pon solicitacão do Iggnifioo Peitor, "Hil ante-projeto ie oniecão do Servico de Televigẽo Educetiva da USP, assil

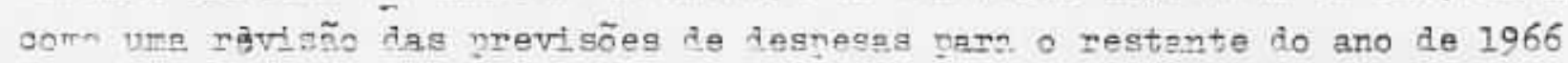
e pars 1967. Tais tocumentos foram enceminharios so Yagnifico Reitor em tritho ie $1966 \mathrm{e}$ enarados so Processo $n=17534 / 64$ is Reitorie. udiance des instalacões nara o Edifíloin da Beitoria

En outubro to ano corrente $=$. Comissão de It! Eduontiva recebeu fício do Dr. Adalberto Hendeg ios Santos, Diretor Erecutivo do Fundo de

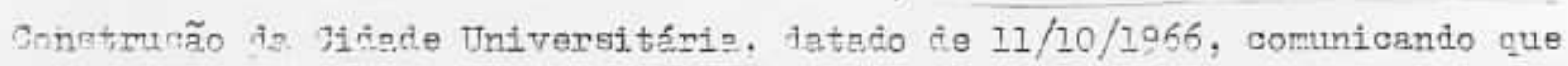

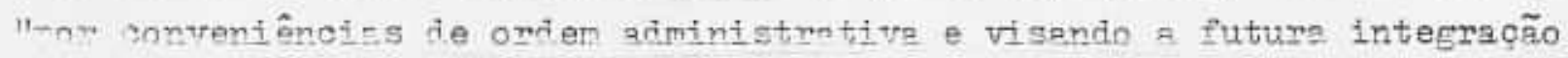
$A$ I Escola de Comunicacões, o estudio d.e T.T. eduontita da Universidade de

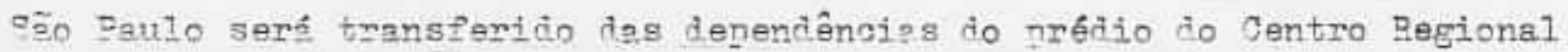
fe Pescuisas țucsoionais pnre o ediffoio ine Deitoria". Te zoôrio, ainda,

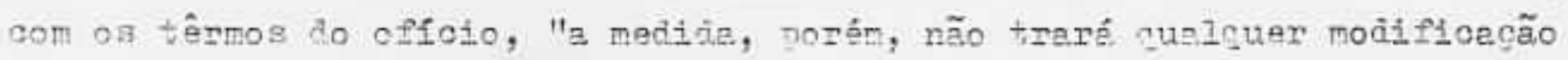
nos plenos nrevistos, continuando o mesto statu-nuo até ulterior delibenecão, inclusive, quanto à competênoin delegada anteriormente a essa digna Domissão".

\section{PESSOAI, I MAMERIAI}

II os sucessivos reletóriog grevarados por esta Comissão, tem sidio gempre goentuado que os problemes relativos ao contrato de pessoaI 9 souigicão de material permanente e ce consumo preoisan ser resolvidos, Pera que \ TelevisR̃o Thducstiva nossa funcionar.

Presentemente, o servico ie Tाt Ecucativa conte slenas com os três membros is Comissão, treinada especificamente nara o projeto nos Estados Jnidos. Im virtude de problemes de ordem finenceira, dois outros membros de Comissão, Dr. Iuiz Antonio Sousa Lima de Yacerio - que se preparou para فste projeto durante um ano na TV educativa da Michigen State Tniversity 
borar no nrojeto. Os nrofs. Samuel Ffromm Netto e Iĺsio Darra, ao mesmo temro cue pertioinam da Comiasão, continuam no exeroício de atividades focentes e ie pesquisa, na tniversidade, no caso do rineiro, e na Universi iacle e no GRFE Enof. Gueiroz Filino, no caso ino serundo. Sömente o Eng. Helson Purper Iisboe, ora 14 gacio so Fundc de Constmeño ila Gilade Universithíris, rem se derigendio exclusivamento à Televisão Educetiva da USP.

Além dos nomes oitados soima, tárias pessoas colaboraram, espontâneamente e sem remunirecão, na instelacão to equijamento, no planejamento do roteino etc. Alvumas dessa.s pessors pertencem so ouadro de pessogl to DRPE Frof. Gueiroz Filiho.

De s.côrio com entendimentos nróvios, a televisão educativa deverte convar, no segunio semestre de 1966, oom a oolaboracão de dois especialist IE Universitace de FI'́rida: O Dr. Kenneth Ohristiansen, Diretor do Serviço ie Meleviaz̃o cessä tniversidade, e, prov̀velmente, o Proł. Nark Damon, 1 lutor e diretor ie propramas. Coningme foi assinelatio antes, o Dr. Thristiansen, aomo assesson do nxo iato, tem zerticinario ativamente dêste ¿esde o inioio, assim como o Dr. John Baxter, da mesma Universidade. Em Virtude de mudanca do Servico de TV nara o predio da Reitoria, a vinda cos especialistas citados só moiená ocorrer, naturalmente, após a congluaẽo ia instalacäo e testagem do equipamento no novo nxócio. Pessoa.

0 custo ìe operacão de um semvico de televisão á elevado, narticularmente no neríodo inicial de funoionamento. Wão obstante a apreciével reducão oue ge obtém cuanio á nossível contar, como se previa no yrojeto orifinsl, com eouinamentos e servicos fa evistentes - neste osso, os servicos e equioamentos de oinema, Ietregem, desenho e "hot press", fotografie, audin sto. do Servicn de Requrang Audiotisuais do CRPE Prof. pueiroz Tilho -- e cnm a solabnracão तe nrofesaôres e estudantes, despessa com o pessoel da equipe de proincão e com a aoviaicão de material indispensável pera a instalação e funcionamento continuam grandes.

Im se tratando de pessoal, o minucioso estudo feito por I. $\mathrm{K}$. Helson (em Educational Television - The Hext Ten Years, ogpitulo sôbre financlamento da televisão educetive) levouto a concluir que sem o mínimo ie lez a doze pessoas f imossível onerer ume peonene unitecie de airouito leohedo que não inciui videotane e se destine apenas e dez salag de aula, em un único edifioio. A medida oue se amnila o equidemento, inoluindo, Dor exemplo, videotade, mais câmares etc., a aे meciidia que o alonnce de televisá se estende para vários ediffcios, aumentam as necessidg jes de pessoal; para operar em circuito aberto, por exemplo, dopendendo ia complexidade das operacões e do número de equipamentos usados, sssin como da natureza de trans- 
-issões etc., ag necessiciadeg de nesscal. nema estacão. î tr educativa, tariam de 23 hare 54 pessons, no mínino.

$\Delta$ s conclusões a cue cherou a Comisgão de Tr/ da Gidiade Tniversitúnia sôbne o nesenol necessánio, em mímero minimo, nana o funolonamento da telev

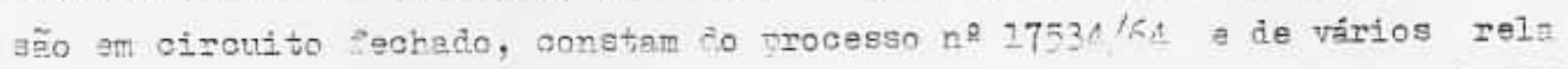
tórios. O pessogi envolvicio na operenão serie: UI Diretor do Serviço de TH $11 \mathrm{~m}$ Engerineiro-Thefe, um Diretor ce Producão exercendo cumulativamente a fur ç̃o de Diretor je oromramas, um encarregado de menutencẽo de eouipamento, opereinn de vileotane, 1 m artista gráfico, overaciores ile oâmara e de audio, essistentes de direção e auxiliares, essim gomo uma seorbtária-datilógrafa. Bùstoamente, êsse pessoal distrithulr-se-ie em três cotezorias: (a) pessoal

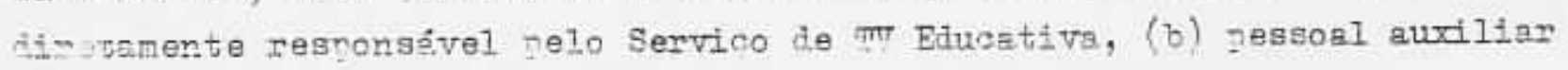
qualificnco, com preparaça em nivel superior nos Đ.U.A. nera trabalhar em tv ecucetiva, (a) gessoel guxiliar oom graus variéveis de experiência, para + Yas de natureza pais simnles.

taterin? jermenente e de consumo

A. Comissão de TV Educativa proceieu, tamỉm, aos estudos neoessáric para prever o minimo de meterial nermenente e de consumo requertio pelo Servico de TV Ednoativar móveis e equidemento, meterial ráfico e fotográ영. material elétrico e ede iluninacão. material ners sets, videotape etc. As iespesas previstes con tail iteng constam imainente do processo $n 27534 / 64$. da Rettoris.

IV. PPOBIEMIAS ITCADOS A YUDATCA PAPA O DDIFIOIO DA RTIMORTA DA TSE

Avós ter sido informada le cue, em virtude de deciaz̃o do Magnificc Beitor, a televisäo educetiva seria transferida pera o trédio da Reitoria, e ce cue tal decisão resultava do fato ie que em tal rrécíto funcionará o recém-crìdo Instituto de Comunicacões, a Comissão de mi Educativa examinov os rroblemss envolvitios nessa mudance, cheqentio d̀s semintes conclusões:

(1) Gomo o mroieto de TV Bancetivn fnt eloboratio levendo-se semprs em conta a instalecão deste no PRPE Prof. Queinnz Filho, funto ao Servico i, Recursos Audiovisuais, em locais orèvismente lesimndos, a compra de equipemento, o sistema de fluminacão e ventilação, os servicos auxiliares eto. estevem, naturelmenta, ajustedos às concicões oforecidas pelo CRPE. Seria necessário, sortanto, estudian a nova loosilzaoñ e venfftedar que mu-

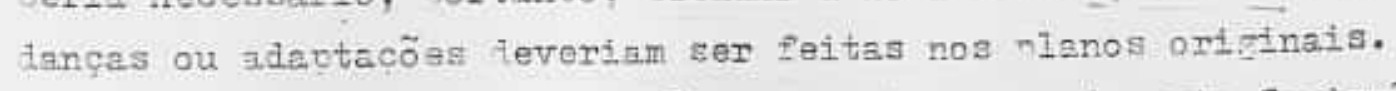

(2) A novr locelizacão apresenta, gegunio esta Comissø̃ę vários inconvenientes -- a localizacão não é no andar térreo, como sempre se recomenda, a altura disoonivel não narece ser adenuada pare $\beta$ instalação da "grid" de iluminacão eto. - e afasta a tv educative do conjunto de 
Servicos tudiovistrais to GRPE. indismensével cers saticfoger grante nerte Aas necegsidedes ie rotina dífria nes úreas ie cine, foto, andio, desenho,

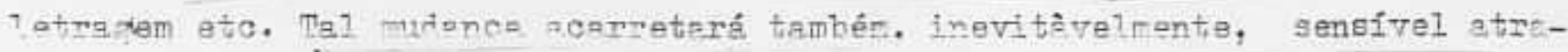

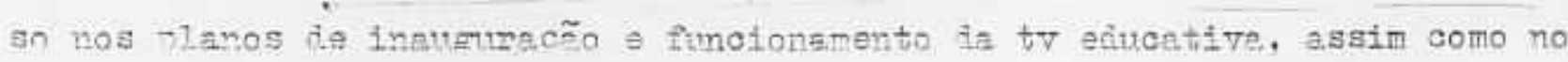
treinamento a ser rronnzoicnacio nelos agmecialistas norte-amemicanog. Admiticr. entrotanto, a decisão de muinnca somo fato consumado, a Comissão

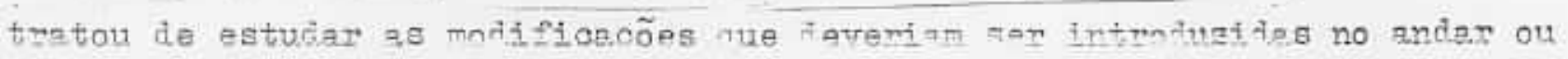
andares destimado(s) ฏ Tr, em sen novo Téñín. O Ene. Telson Purper Lisboa alaborou, nesse sentido, planos hara es noves instalacöes, aue foram entre-

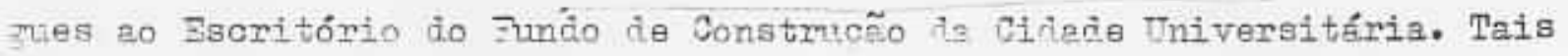
-lenos inoluem, al6́n do estridio, sala de contrôle e esoritórios, anteriormen-

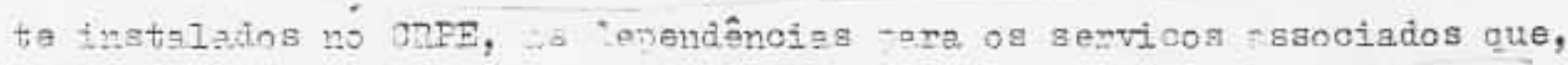
de zocirio com os Jlanos anteriores, seriam realizados nelo Servico de Recursc Audiovisuais do CRPE Prof. Queiroz Filho. Gonvén scentuer que tais serviços associadios devem funcionar junto à televisão, pois destinam-se a satisfazer

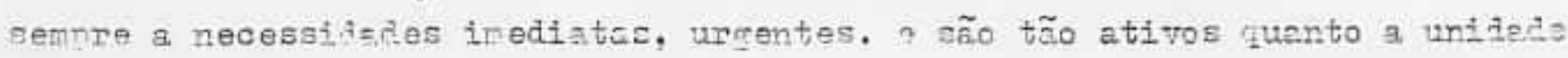

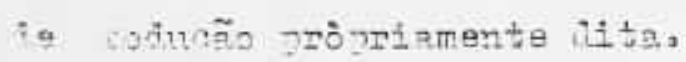

(3) Tem a On-izañ ie TV nem od assegeôner in. Fundacõo Ford e da Univer siznde de Flórida, aue estão orientando o mojeto, foram ouvitas sôbre a conventência ou näo Al mudanca - quo, z. esta 21 turs, é considerada pela

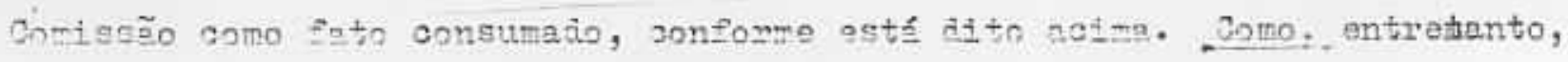

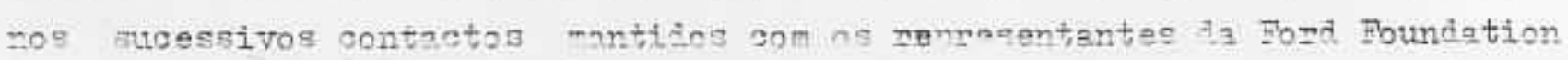

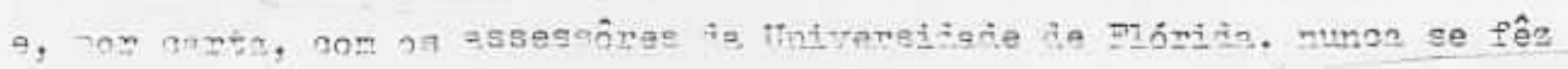

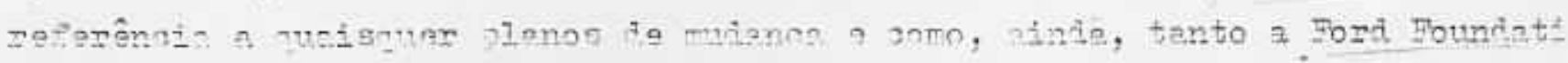

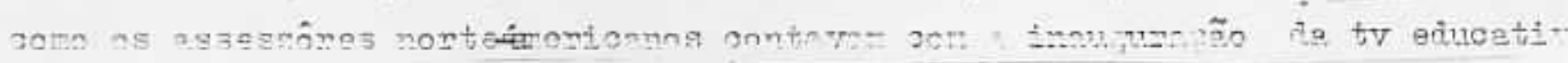

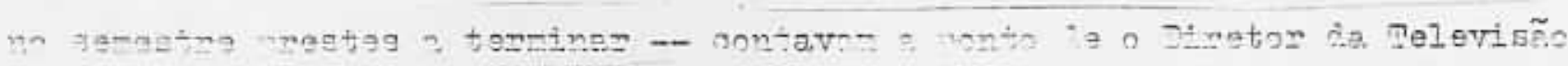

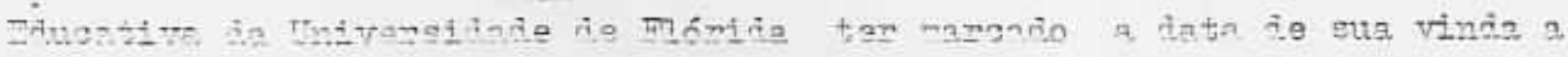

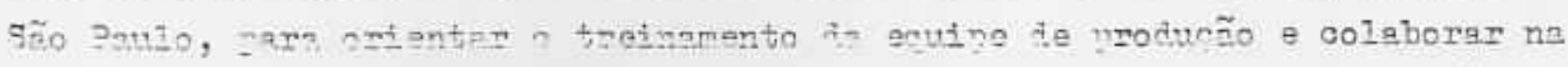

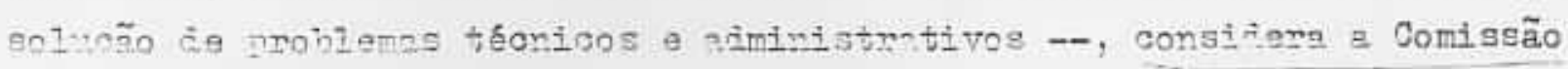
que s de tôda sonventênoi= sejan ? Fumciagño Ford a o Dr. Kenneth Christian-

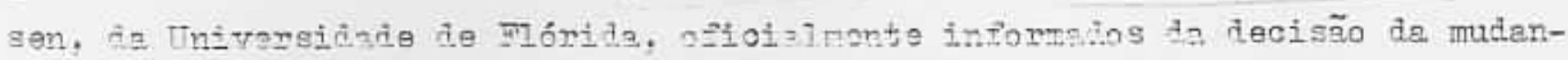
ca. Aoreditam tembér aue essn informecão ofici-l A.eva ser feita ao Dr.

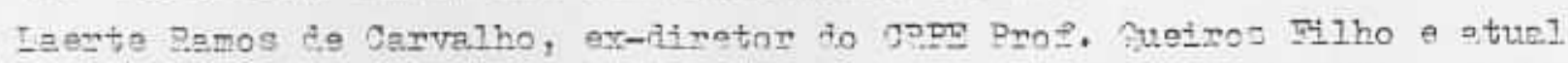

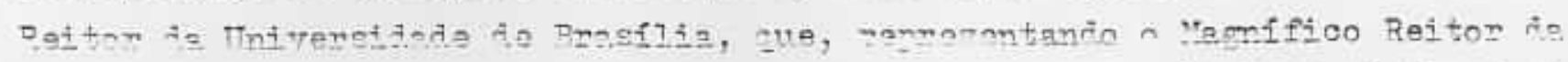

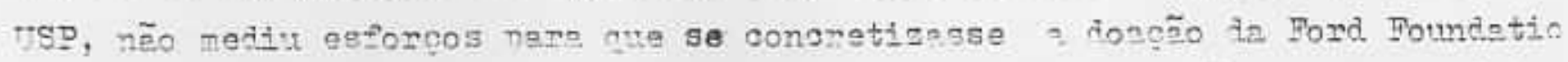

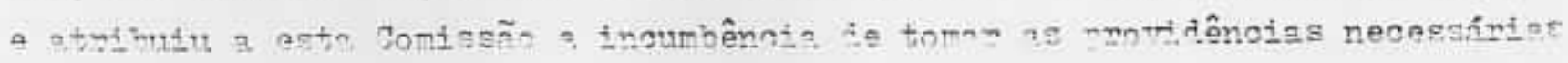

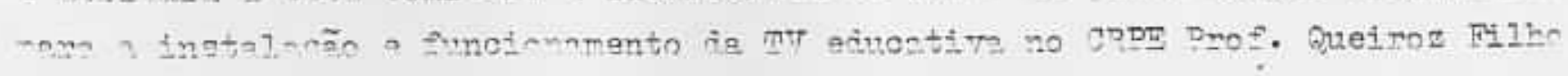

\section{T. PROTTDSTCIAS NECESSARTAS}

Fm virtuce do atraso consicigrével tue renresenta, para a implantaç̃o io siefema ile TrT entuostiva na USP, a minnen de todo o equipemento para o 


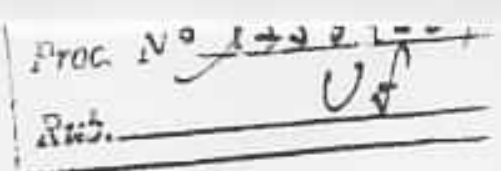

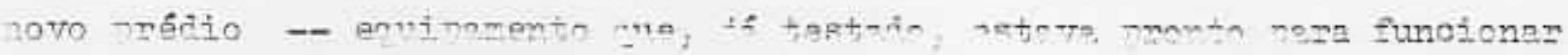
intemmente, no treingmento do grvine -.. g tento on ristz $z$ necessidacie

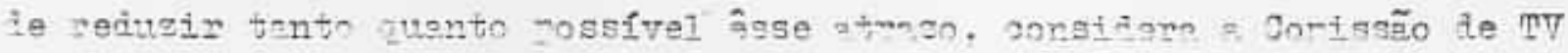

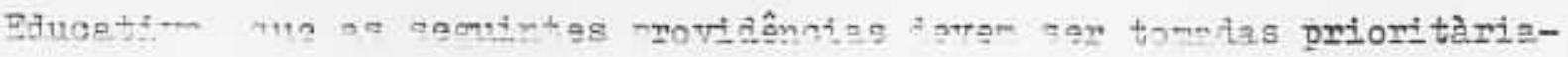
mente:

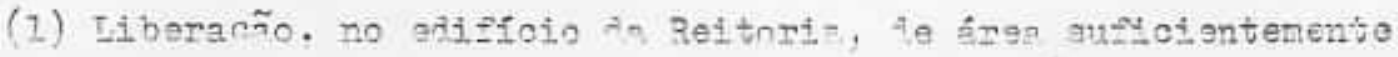

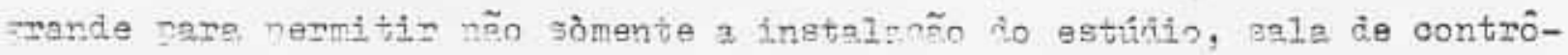
Ie e escritóring como também br trixios servicos internos indispenséveis vera o funcionemento ia tv; conforme os nlanos elaborados no Funio de Construtõo ie OAdade Tnitergitéria;

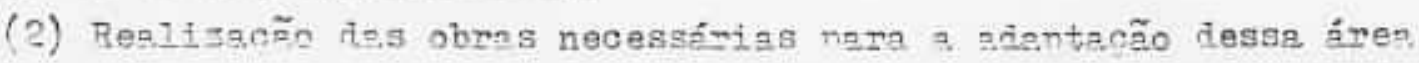

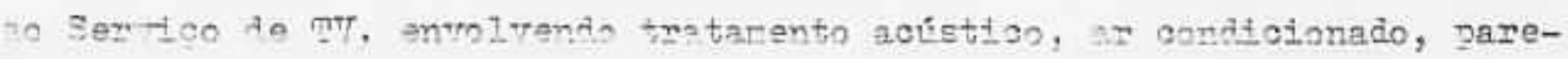
tes Al fisónies, bases pera videotape e ruIti-lexer, râlie de energía, instalzcõo ze "grid" de iluminanão eto.;

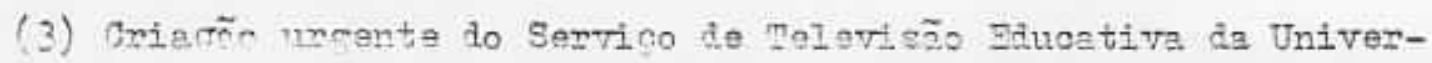

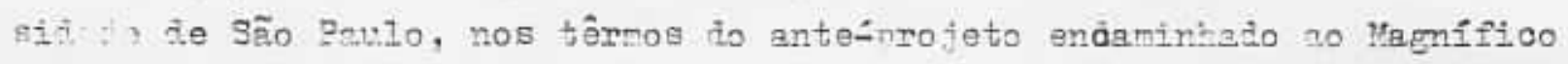

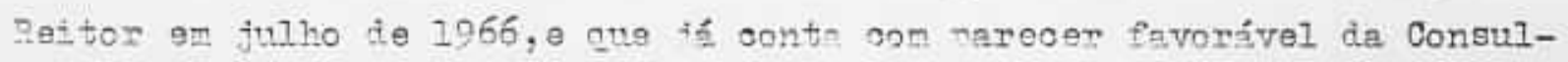
toria Juridica, ou en têrmos que os substituan;

(4) Iiberação de verbas pars s contrrtaç̃ te jessoal e formação in eouite ie producão e euriliares, bem somo hem 1 aq1if sinano de material anmnanta $e$ de anraumo;

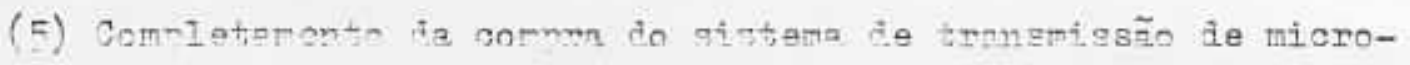

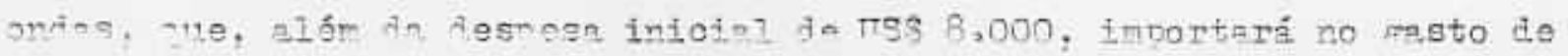

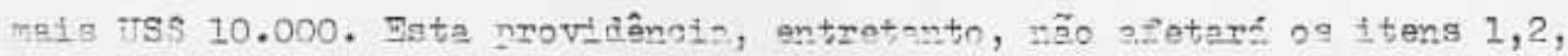
3 e 4 zof mn, Tiqto anmo funcioremento An tv educative, רms fins ie treinamento interno de sue equi-g, rodenéf ter intio assim cue se fossa conter onm o equizamento ie producão instalodo o testado $e$ com o pessoal devidizmente contratado;

(6) Entendimentos entre o Namifico Reitor, D Diretor da FacuIdacie da Filosofia, Olênoins e tetras e os Catedrítioos dor Departamentos 4. due pertiencem hois membros desta Comissão, Đ fim de se chegar a um. acôrico que nermita maior envolvimento dêstes iltimos nas atividacies da telsvisão, if que, presentemente, suas resronsabilifades docentes a de Descuise limitan sensivelmente o tempo de que jisnõen hare as tarefas -. que tendem a se tomer oada vez naiores - na fren ia tv eiucativa.

São Paulo, 7 dezembro 1966 Comi sรão de Televisão Tauortiva: SamueI Dfromm Netto NeIson Purper Lisbon 


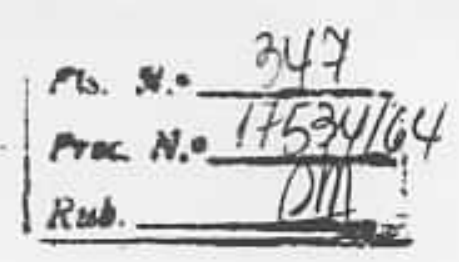

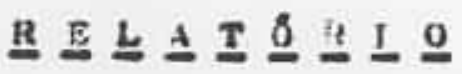

(Ner. eorreapondênesa de 92 de Janeiro de 1.969)

1 - Latalpemento

As primelrae modidas de order prítiea, rolativao mente to projeto da TV Lidueativa da Universidade de såo Paula foran tomadas no sentldo do tuo contatos fosso reallgadoe cea eapeolaliatas norte-americanos, para quo a aloģอ do oqulpe-

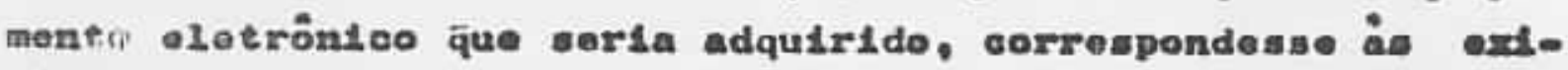
gênelas téenicas dotorainndas pelo proessso de gravaçe o trananisaño de nula» pela televisüo.

Após tor viextado diveraas Untveraldados dos Beo

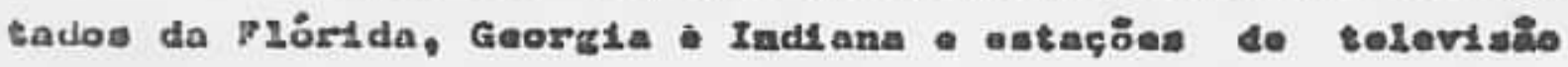
comerchal a aducat1va, - Ligg Neleon Purpor Llaboa, Juntanen-

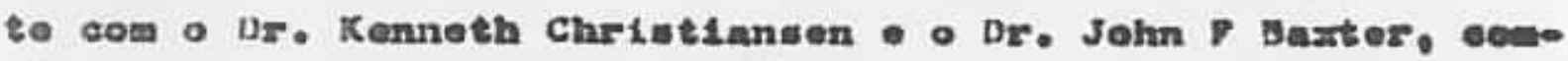
pôs a líata do matorlal eletrón1co. A eggulr, roram conmaltadal al firmas RCA-Victor, General fletrie, Dage, Kinmed e Sarkos Tarsian Ine., tendo esta úlelea apresentedo molhor equlpamento a mala homogenea linha do componentea.

Depois do selocionado o equipamento, na pabpria fábrica da Sarkes Tarsian Ine., on Bloomington, Indiana, fos fachado a contrato pelo valor total de USS 136.600 .00 ( Cento - trinta o sola mil salmcentos dólarea), inclusive frote e seguro. O matorial adquirldo eorrespondia ao mintmo necesahrlo para o functonamento de us elroulto fechado aplieado ¿

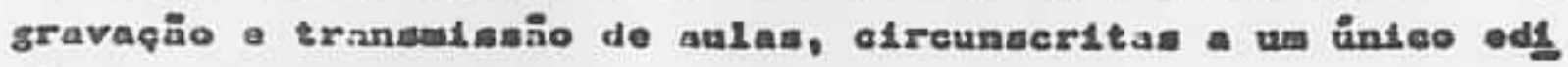
fleio. Foram Importadoss 


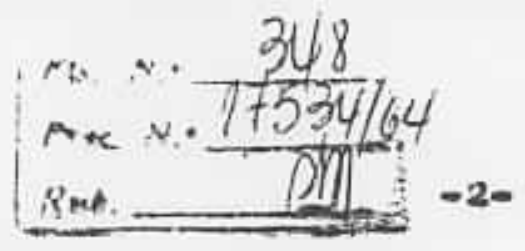

3 sabeçotes de aúmera ețva de 2,5 " modele $89-248$

3 unidades de procenanento mode10 35-250

3 aaboa con 25 pés para cámeras coe aneatore⿰, modele V-25 B.

I controles zumotos de dupla açāo aodolo $85-272$

3 abbos coa 50 pés para cämeras, do aztunsāo, mode10 V-50 B

3 tubon vidieon de $1.5^{n}$, modelo 3521

30.600

1

usjativa zoon - 25 - $350 \mathrm{~m} / \mathrm{a}$ f/ 3. I 1021 com controle romoto moo de 10 56-098

3.500

Objativas CaNNON TV 88 zoom 8" I/4 aom Irsa do controla rumoto modelo 56-103

objativas CANNON TV 38 5" $8 / 2.8$

$155 \mathrm{~m} / \mathrm{m}$ modelo 56-102

Objet1vas CARNON TV 38 2" $8 / 2$ $50 \mathrm{~m} / \mathrm{m}$ aodelo $56=099$

Cämera de Teloviäo para rılo • alśdes raodelo $1500 \mathrm{~V}$ eomposta des

2 eabeçote de câmera ativa modelo 85-249

1 controle de aünora modelo BS. 250

1 abo aon 25 pés pura cümera eca convetoras morlelo V-25 DR

1 Tubo Vidicon de 1.5" modelo 3521

1 Objativa $2.04 " 2 / 1.5$ modelo 36-040 


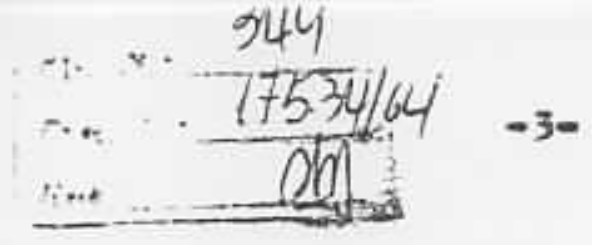

transporto

1

I

1

I

1

1

1

3

3

5

6

1

10

3

3 60 des uesum 85-25/ incluindo: dolo 85-256 trontz modelo $107-198$ $107 / 274$ 129
Slatema do eapolhos prtamít1eos para 3 ertradan modelo MPeso M

Projetor para f1lme $16 \mathrm{~m} / \mathrm{a}$, eod pedeotal marea Boll 6 Retreil mocolo cDVA 624 a tipe TaH - 14

Us?

44.230

2. 450

3.000

Controle remoto duplo para proje isor de P1Im alldes wodelo $P P C=20$

400

Projetor do alsdea MANDON ACESS para 50 alldal con anporte tambor de reserva modelo TSP -

2.500

Objetiva para o projetor da s11-

60

Gerador de elnerontmo modele o

2 gerador do 11nhas aruzadas mo-

3. 400

Hean metalicaa tipo consolete para colocação doi monttorea controles modelo SC-15 B

Monteras de Televiuio duplon de 8" narea Conrae, modelo 107-171

2. 860

Monteorea de rorrsa de onda Tals -

5.500

Menttores de Talevila io do $17^{\circ}$ ou easiza de aço aurea CGNRAC modelo

8.200

S1atema do intorcomunxeaçāo de sod cormpeato modelo $85-265$

500

Fones de ouvtdio modelo $107^{\prime} 120$

750

Podestals com rodizisa pora as oj meras maroa BuncimaNM nodolo 1077

1.560

Bercon articulados para muportar as eàmera marce HAUSTUN PE,illiss modelo $107-184$

2.560

68.395 
2

Cabszos cen palnás de 2 lados

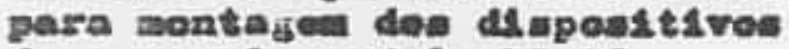
de controle modelo un 28

Merofones ELETRO Vexcr tipo Lavalies modelo 107-226

450

2

3

1

MSerogone SLETRO YOICE tipo mear moivio $107-258$

200

Pectestal para ateroronea AThds HS 223 medole $P 2043$

25

Pedostal de mona para meroroo nea SLLTio vorCz modelo 429 ts po 107-257

\section{Chave selatora para video} and10 oom 6 entradas 4 cal das murea DINAIR modolo P 1044 Gquipamento completo para ro produçäo de dlacan ronegrártcos marca GATrs espo cB-83 modeloP 2045

\section{0}

1

Mesa do comando para dsatribui ६̧äo do audso marca GaTes espo Consolot modelo CA $\mathbf{2 0 0 0}$

Alto ralantes do duplo cone of cajiza acústica tspo LC 1.t mode 201 P. 1046 e P 1047

Alto salantos de $12^{\prime \prime}$ modelo $\mathrm{P}=$ 2048

Amp1121cadores de andlo com val vulag moctolo It 4375 P 1098

Conjuntor de basos conectorn para interaonerióea tipo BA 31 modulo P 1060

Jegos to valvelas para on appli rleadoras actma t1po 399 modelo P 1062

Qacsloacópilo para toata mareaTytrtidzx tipo 535 t modalo :1064 
ANEXO IV - Carta enviada ao Departamento de Recursos Humanos da USP pelo UNIVÍDEO/Cecae 


\section{Sr. Presidente}

O Conselho de Planejamento do PROJETO UNIVÍDEO/CECAE toma a liberdade de encaminhar à essa Comissão alguns comentários sobre o Plano de Carreira de Pessoal não Docente da USP, recentemente implantado, com o objetivo de colaborar para o aprimoramento das diretrizes nele apontadas.

O PROJETO UNIVÍDEO/CECAE vem atuando na USP no sentido de desenvolver algumas ações que favoreçam o mapeamento, aglutinação e expansão das atividades com recursos audiovisuais já desenvolvidas de forma dispersa em várias Unidades da USP.

Neste momento, considerando principalmente as perspectivas colocadas pela PRCEU para o desenvolvimento de atividades de Educação à Distância e também por existir uma significativa produção de vídeos e filmes realizada com recursos e técnicos da própria USP, é da maior importância que a estrutura funcional da Universidade atenda à complexidade do fazer audiovisual, dispondo de funções suficientes e capazes para serviços voltados para uma demanda crescente e cada vez mais valorizada pela Sociedade e também pela própria USP.

Ao tomar conhecimento do Plano de Carreira recém implantado, o Conselho de Planejamento do PROJETO UNIVÍDEO analisou em detalhes as funções descritas na área de Comunicação e apresenta aqui os seguintes comentários:

- apesar do Plano de Carreira contemplar diversas funções relativas à produção de Imagem e Som, as específicas para realização de vídeos e filmes são insuficientes.

- as atividades relativas a vídeos e filmes podem ser divididas em três níveis:

o básico, que se refere a instalação, operação e conservação de equipamentos de exibição de vídeos, áudio e filmes (televisor, vídeo cassete, projetor de filmes, gravadores de som, etc. )

o médio, que abrange a operação de equipamentos sofisticados de captação de imagem e/ou som, de edição de vídeo e/ou áudio e de aparalhos do tipo geradores de caracteres, de efeitos especiais, de computação gráfica, cuja manipulação requer especialização

o nível superior, que envolve as atividades de produtor e de diretor, que soluciona aspectos criativos da linguagem audiovisual, coordena a equipe de trabalho, assessora a elaboração de projetos, define sistemas de equipamentos. 
- a produção de vídeos e filmes, ao contrário da exibição que pode ser feita por uma só pessoa, será sempre executada por uma equipe de funcionários, implicando numa hierarquia e numa divisão de funções que são complementares e que se distribuem nos três níveis acima indicados.

- a melhoria da qualidade e da quantidade da produção audiovisual (especificamente vídeos e filmes ) da Universidade de São Paulo, é um anseio da comunidade acadêmica e de políticas recém propostas pela PRCEU e outras áreas que, para implementarem-se necessitam do respaldo de uma estrutura funcional capaz de atender as demandas próprias da área.

Esperamos com esses comentários estarmos evidenciando nossa disposição de contribuir com os esforços dessa Comissão no sentido de aperfeiçoar as condições de trabalho nesta Universidade e pomo-nos ao inteiro dispor de Vs. Ss. para um diálogo através do qual possamos estar cumprindo os objetivos do PROJETO UNIVÍDEO.

Cordialmente,

Presidente da Comissão Central de Recursos Humanos

Prof. Dr. Helio Nogueira da Cruz

cc PRECEU/ Reitoria/ Sintusp. 
$\underline{\text { ANEXO V - Descrição de atividades na produção de vídeo }}$ 
Apresentamos a seguir um quadro sucinto das atividades desempenhadas pelas principais funções de uma produção de vídeo. As formas de organização do trabalho variam conforme as áreas de produção, no mercado publicitário há um alto nível de especialização, na televisão estrutura-se uma linha de atividades extremamente segmentada e ágil, como uma indústria, o fator determinante é sempre o financeiro, mas o contexto do trabalho e seus propósitos também influenciam a composição de uma equipe. Na produção de documentários, geralmente, as equipes são reduzidas a poucas pessoas, todavia as funções básicas sempre serão atendidas. É para esse caso a presente descrição, considerando uma proposta de trabalho integrado e participativo, com as pessoas interagindo desde a apresentação do tema do documentário e dos propósitos em vista, o grupo vai discutir a forma de organizar as atividades e, coletivamente, acompanhar cada etapa de sua execução.

Pesquisa - é a busca de informações dos aspectos estabelecidos pela equipe da produção. Recorre a fontes bibliográficas, mapotecas, iconografia, entrevistas, internet e publicações diversas. Numa etapa seguinte, a pesquisa desenvolve-se "em campo", coletando informações diretamente no ambiente onde serão feitas as gravações.

$\underline{\text { Roteiro }}$ - é o mapa de orientação da equipe no transcorrer da produção. Como texto indica onde e o quê será gravado, qual a pauta das entrevistas, quais os aspectos mais relevantes devem ser registrados. Na produção de documentários, geralmente, prepara-se um préroteiro antes das gravações, o roteiro definitivo será elaborado após a coleta de todo o material visual e sonoro e será feito a partir da análise desse material.

Direção - num sentido estrito a direção define como será feita a gravação, qual a posição da câmera, o enquadramento, o decorrer da ação a ser gravada, orienta a edição do material, articulando as cenas, as sequiências visuais e sonoras. Num sentido mais amplo a direção cuida de manter uma coerência e uma intencionalidade nas atividades de toda a equipe, evitando que a idéia se dilua perdendo expressividade. 


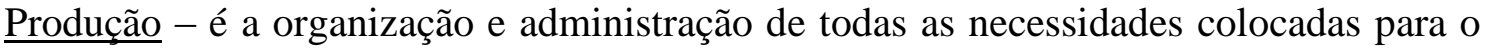
bom andamento dos trabalhos da equipe. Obtém as autorizações de gravação, providencia o transporte, a alimentação e demais materiais necessários aos trabalhos. Atua criativamente na busca de locações, ambientes e situações, que contribuam para a expressão audiovisual do trabalho.

Captação de imagem - atividade de caráter técnico e artístico, implica na operação da câmera mediante o conhecimento detalhado dos ajustes possíveis em relação a luminosidade, contraste, cores, tipos de lentes e filtros, movimentos. Envolve um apurado senso de composição visual e de criatividade na captação de imagens significativas para o tema em foco.

Captação de som - as atividades são semelhantes ao trabalho com a imagem. Há uma tendência a super valorizar o visual em detrimento do sonoro, mas sua realização exige grande sensibilidade e conhecimento técnico.

Assistência técnica - principalmente na captação de imagem, que envolve um maior aparato de equipamentos, é necessário o apoio técnico na montagem da câmera, do tripé, na organização das baterias, fitas de vídeo, filtros e demais acessórios, e também no transporte de todo esse material.

Iluminação - a luz é o princípio do trabalho de imagem, envolve conhecimento técnico de fotometria, colorimetria, dos diversos tipos de refletores, do posicionamento, da intensidade e da natureza das luzes. Exige sensibilidade artística para a obtenção de resultados adequados à expressão visual.

Edição (ou montagem) - essa atividade é da maior importância na realização audiovisual. Além do conhecimento técnico na operação do sistema de edição, que envolve informática e tecnologia de vídeo, é necessário o domínio das formas de narrativa audiovisual, do uso de efeitos visuais e sonoros, do ritmo. O trabalho consiste na seleção e ordenação das imagens, entrevistas, textos de locução, sons, artes gráficas, e na sua articulação para compor uma história harmônica, verossímil e envolvente. A edição é a 'alma' do audiovisual, sem ela as imagens, por mais expressivas que sejam, serão apenas retalhos de uma idéia. 
Divulgação e distribuição - concluída a produção é necessário um trabalho que viabilize a exibição do vídeo em larga escala, ampliando seu alcance social. Não existem formas consolidadas de veiculação de vídeos 'independentes'. Conforme o objetivo da produção e o público visado deve-se organizar estratégias específicas de divulgação mediante a publicação de releases na imprensa escrita em geral e na especializada, o envio de mala direta, a participação em mostras e festivais de vídeos, o contato com emissoras de televisão que tenham programações compatíveis com o trabalho realizado e também a preparação do material para atender a pedidos cópias. 
$\underline{\text { ANEXO VI - Projeto de Capacitação de Docentes enviado ao Departamento }}$ de Recursos Humanos da USP pelo UNIVÍDEO/Cecae 


\section{UNIVÍDEO \\ CECAE}

818-4165

São Paulo, 24 de Novembro de 1999

\section{Prof. Dr. Gilberto Tadeu Shinyashiki DD Diretor de Recursos Humanos - USP}

Venho encaminhar a V. S. a documentação do Programa de Capacitação de Docentes para a Produção de Material Didático em Vídeo e Multimídia.

Conforme nossa conversa quando da análise das demandas e possibilidades de desenvolvimento de programas dessa natureza, encaminho também uma primeira avaliação das necessidade de pessoal e orçamento.

Lembro também que o pleno desenvolvimento do Programa demandaria ainda a capacitação e/ou aperfeiçoamento de funcionários técnicos das unidades que tivessem projetos de docentes realizados a partir das orientações do Programa. No entanto, a avaliação mais precisa dessas demandas só poderá ser feita cruzando-se as informações obtidas no desenvolvimento dos cursos e os dados compilados e analisados no Diagnóstico do Potencial de Produção em Novas Tecnologias na USP, que está em fase de finalização no UNIVÍDEO, com previsão de conclusão em abril de 2000.

Por essas considerações avalio que estes documentos tenham um caráter de orientação para previsão orçamentária, ficando o Programa sujeito ao aperfeiçoamento de seus custos e procedimentos, ainda que dentro dos patamares indicados.

Assim encaminho à V. apreciação:

- Curso de Iniciação ao desenvolvimento de projetos pedagógicos em novas tecnologias programa e orçamento

- Curso de Iniciação ao planejamento e a roteirização de vídeo e multimídia - programa e orçamento

- Bolsas de apoio para a produção dos projetos desenvolvidos - orçamento e condições de desenvolvimento

À disposição para qualquer esclarecimento,

cordialmente,

\section{Profa. Dra. Marília Franco}

\section{$\mathrm{CC}$}

Prof. Dr. Guilherme Ary Plonski

DD Coordenador da CECAE 
CECAE

818-4165

PROGRAMA

CAPACITAÇÃo de docentes PARA PRODUÇÃo de MATERIAL DIDÁTICO EM VIDEO E MULTIMÍdiA

\author{
CURSO \\ Iniciação ao desenvolvimento \\ de projetos pedagógicos com novas tecnologias
}

Carga horária

12 horas/aula em 4 períodos de 3 horas.

Número de alunos por turma

30 alunos

Objetivos

Orientar a realização de um tratamento inicial de projetos de produção audiovisual nas mais diversas mídias através da informação das aplicações pedagógicas, elementos de linguagem audiovisual e recursos tecnológicos e humanos envolvidos no processo de produção.

Justificativa

Há a necessidade de aumentar a comunicação de disciplinas, pesquisas e especialidades através de difusão multimídia. Para tanto os docentes devem estar aptos a criar projetos de comunicação multimídia completos, utilizando as novas tecnologias disponíveis.

Esse curso oferece uma introdução sobre a atividade de criação de material didático utilizando novas tecnologias, permitindo que docentes integrem a comunicação multimídia em seus projetos.

Conteúdo

- Implicações e aplicações pedagógicas de novas tecnologias

- Linguagens audiovisuais e multimídia: semelhanças e diferenças

- Aparato tecnológico e humano

- Pesquisa e diagnóstico de anteprojetos

Metodologia

Todo o desenvolvimento do conteúdo será feito levando em conta propostas de projetos trazidos pelos alunos, de modo que cada participante saia com um pré-projeto ao final do curso.

Docentes com projetos selecionados pelo SIAE

Público alvo

Docentes de quaisquer unidades da USP

Coordenadores de projetos que envolvam produções audiovisuais e de multimídia

Apresentação de uma proposta de produção de material didático utilizando novas tecnologias

Requisitos 


\section{UNIVÍDEO}

CECAE

818-4165

\section{MULTIMÍDIA}

\section{ORÇAMENTO DO CURSO \\ Iniciação ao desenvolvimento de projetos pedagógicos em novas tecnologias}

No. de horas: 12 horas/aula - 4 períodos de 3 horas

No. de vagas: 30

No. de docentes: 4

Apoio logístico: produção, desenvolvimento e avaliação do curso de estagiário do DRH orientado pelo UNIVÍDEO (já designado)

Custo: R\$150,00 (cento e cinqüenta reais) por docente incluindo elaboração de material didático a ser distribuído para os alunos.

Custo/aluno sem material didático e encargos - $\mathrm{R} \$ 20,00$

Total por curso - $\mathbf{R} \$ \mathbf{6 0 0 , 0 0}+$ encargos

Previsão: 1 curso por semestre em 2000

Resultados previstos: : desse curso serão selecionados 10 pré-projetos a serem desenvolvidos no curso de Iniciação ao planejamento e a roteirização de vídeo e multimídia

A seleção deverá ser feita levando-se em conta, além da qualidade didática dos pré-projetos, as reais condições de produção apresentadas pelo docente/departamento/unidade, a partir do potencial de tecnologia, RH e recursos financeiros e das práticas já desenvolvidas pelo docente/departamento/unidade. 


\title{
UNIVÍDEO \\ CECAE \\ 818-4165
}

PROGRAMA

CAPACITAÇão de docentes Para PRodução de material didático em Video e
MUltimídia

\author{
PROGRAMA DO CURSO \\ Iniciação ao planejamento e a roteirização de vídeo e multimídia
}

Carga horária

30 horas/aula em 10 períodos de 3 horas.

Número de alunos por turma

10 alunos

Objetivos

Analisar os elementos de linguagem que caracterizam produções audiovisuais e multimídia.

Identificar as etapas básicas de elaboração de projetos.

Acompanhar e orientar a prática de realização de um roteiro audiovisual e de multimídia.

Justificativa

Diversos projetos ligados ao ensino e à pesquisa têm se utilizado dos recursos audiovisuais e de multimídia como ferramentas de auxílio no processo de difusão do conhecimento.

Para que esses projetos possam alcançar plenamente seus objetivos de comunicação é preciso que eles sejam produzidos de forma consistente no que se refere ao desenvolvimento do conteúdo.

Para tanto, é fundamental dedicar uma atenção especial à elaboração dos roteiros dos projetos, cujo papel consiste em organizar e estruturar os elementos do projeto fornecendo-lhe a linguagem e o formato necessários a sua realização.

Além disso, o roteiro é um elemento que permite visualizar o produto em sua forma final, possibilitando identificar, previamente, as necessidades de produção colaborando, assim, para evitar problemas na fase de realização e finalização.

1 - Função do roteiro nas produções audiovisuais e de multimídia

Conteúdo

2 - Tipos de roteiro: linguagens e formatos

3 - Elementos estruturais do roteiro: linguagens e formatos

4 - Etapas do processo de elaboração do roteiro;

5 - Desenvolvimento e finalização do roteiro

Metodologia

Os tópicos do conteúdo serão desenvolvidos em aulas teóricas expositivas; aulas práticas de análise dos elementos de linguagem dos roteiros a partir da exibição de diferentes tipos de produções; análise e discussão de pré-roteiros; orientação e acompanhamento no desenvolvimento dos projetos

Público alvo

Docentes com projetos selecionados pelo SIAE

Docentes de quaisquer unidades da USP

Coordenadores de projetos que envolvam produções audiovisuais e de multimídia

Requisitos

Ter um pré-projeto selecionado no curso de iniciação ao desenvolvimento de projetos 


\section{UNIVÍDEO}

CECAE

818-4165

CAPACITAÇÃo de dOCENTES PARA PROdUÇÃo de MATERIAL didÁtico EM VIdeO E MULTIMÍdIA

\section{ORÇAMENTO DO CURSO \\ Iniciação ao planejamento e a roteirização de vídeo e multimídia}

No. de horas: 30 horas/aula - 10 períodos de 3 horas

No. de vagas: 10

No. de docentes: 2

Apoio logístico: produção, desenvolvimento e avaliação do curso por estagiário do DRH orientado pelo UNIVÍDEO (já designado)

Custo docente: $\mathrm{R} \$ 150,00$ (cento e cinqüenta reais) por período incluindo elaboração de material didático a ser distribuído para os alunos e supervisão da correção dos trabalhos elaborados ao longo do curso

Total docentes: $\mathbf{R} \$ \mathbf{1 . 5 0 0 , 0 0}$

Apoio didático: para orientação do desenvolvimento dos projetos: 2 estagiários - sendo um com especialização em produção de vídeo e um com especialização em produção de sites e Cdrom.

Esses estagiários trabalharão por seis semanas sendo uma de apoio à preparação do curso e cinco de desenvolvimento do curso.

Suas tarefas serão de atender aos alunos no desenvolvimento dos projetos sob a supervisão dos docentes do curso.

Custo estágio: considerando-se que esses estagiários sejam selecionados a partir daqueles que cursam os dois últimos anos da graduação e trabalhem 20 horas semanais, o custo por estagiário seria de $\mathrm{R} \$ 475,00$ (seis semanas)

Total estagiários: $\mathbf{R} \$ \mathbf{9 5 0 , 0 0}$

Custo por aluno: $\mathrm{R} \$ 245,00$

TOTAL DO CURSO: R\$ 2.450,00

Previsão: 1 curso por semestre em 2000

Resultados previstos: os alunos sairão do curso com os projetos de vídeo, site ou CDrom completos e prontos para a produção, tanto no que diz respeito ao planejamento didático e estético quanto aos orçamentos e procedimentos necessários para a realização. 


\title{
UNIVÍDEO \\ CECAE \\ 818-4165
}

\section{CAPACITAÇÃo dE DOCENTES PARA PRODUÇão DE MATERIAL DIDÁTICO EM VIDEO E MULTIMídiA}

\author{
Bolsas de apoio para a produção dos projetos desenvolvidos
}

Justificativa

A implantação e o desenvolvimento deste Programa, no ano 2000, deverá ter um caráter experimental, para implementar novos procedimentos de produção de material didático com uso de novas tecnologias, em ritmo mais acelerado e envolvendo atividades multidisciplinares e equipes multifuncionais.

Os projetos desenvolvidos durante os cursos receberão um apoio adicional de RH especializado para viabilizar sua realização dentro de prazos curtos.

A supervisão e o controle dos conteúdos ficará com os docentes geradores dos projetos e as atividades que exigem capacitação especializada serão desenvolvidas por estudantes - bolsistas que tenham comprovada formação.

A concessão dessas bolsas representa um esforço inovador da Universidade no sentido de garantir resultados práticos e imediatamente aplicáveis do Programa de CAPACitação DE DoCentes PARA PRODUÇÃo DE MATERIAL DIDÁTICO EM VIDEO E MULTIMÍDIA

Metodologia

Cada um dos 10 projetos desenvolvidos terá cerca de seis meses para sua produção.

Nesse período cada projeto contará com 5 bolsistas sendo 2 permanentes, responsáveis pelo apoio técnico e viabilização do cumprimento de prazos e 3 que apoiarão, em rodízio, as atividades mais específicas e que necessitem menos tempo para desenvolvimento.

Número de bolsas de apoio

Calculam-se 32 bolsas de $\mathbf{2 0}$ horas sendo 20 representadas pelos dois estudantes vinculados permanentemente a cada projeto e 12 para o rodízio de funções.

Custo de cada bolsa ...........R \$ 317,00 mês x 6 meses.....................R $\quad 1902,00$

Custo total das bolsas por seis meses $(32)$..................................R $\$ \mathbf{6 0 . 8 6 4 , 0 0}$

Supervisão

Esses bolsistas deverão ser supervisionados por dois coordenadores do Programa com experiência em produção audiovisual e informática.

Esses supervisores terão a função de:

- orientar os procedimentos técnicos mais adequados a cada projeto;

- orientar a escolha dos bolsistas;

- orientar a distribuição dos apoios operacionais pelas Unidades com maior infra-estrutura técnica;

- acompanhar o cumprimento dos cronogramas;

- viabilizar soluções para problemas imprevistos durante o processo de produção;

- orientar formas de avaliação dos resultados do uso dos produtos desenvolvidos.

Apresentar relatório do desenvolvimento do Programa que possa orientar a continuidade e ampliação dos procedimentos experimentais. 


\section{É altamente desejável que haja um pró-labore para essa atividade de supervisão.}

Compromisso da Unidades

O Programa deve prever formas de conquistar o apoio das Escolas e dos Departamentos cujos docentes tenham projetos selecionados para a realização.

Do mesmo modo precisa conquistar a parceria daquelas Unidades que formem os alunos (bolsistas potenciais) para as funções técnicas específicas desses tipos de produção e que, por conseqüência, tenham já instalada a capacidade técnica para essas produções.

\section{Resultados esperados}

Esta etapa do Programa representa a garantia para a boa conclusão de todo o processo, sendo o papel dos supervisores e o apoio das Unidades decisivos para viabilizar a finalização dos produtos e seu imediato aproveitamento pela comunidade acadêmica.

A boa qualidade dos materiais produzidos será indicativa da constituição de um acervo de material pedagógico com potencial de venda para o mercado de educação e cultura. 


\section{UNIVÍDEO}

CECAE

$818-4165$

PROGRAMA

\section{RESUMO DO ORCAMENTO}

\section{1) Iniciação ao desenvolvimento de projetos pedagógicos em novas tecnologias}

* TOTAL POR CURSO - R\$ 600,00 + encargos

* pagamento exclusivo de docentes

2) Iniciação ao planejamento e a roteirização de vídeo e multimídia

* TOTAL DO CURSO: R $\mathbf{2 . 4 5 0 , 0 0}+$ encargos

* pagamento de docentes e estagiários

3) Bolsas de apoio para a produção dos projetos desenvolvidos

Custo total das bolsas por seis meses (32)..........* $\mathbf{R} \$ \mathbf{6 0 . 8 6 4 , 0 0}+$ encargos

* pagamento exclusivo de estagiários

mais pró-labore dos supervisores

que poderão ser docentes ou funcionários técnicos de nível superior 
$\underline{\text { Anexo VII - Funções existentes no Plano de Carreira dos funcionários da }}$ USP compatíveis com produção de vídeo. 
DADOS DE IDENTIFICAÇĀO

Funçāo

Grupo

OPERADOR DE AUDIOVISUAL TÉCNICO

Inicio I A

Fim III J

\section{DESCRIÇĀO}

A partir de uma programação de trabalho previamente estabelecida, realiza trabalhos de transmissão e captaçāo de imagem e som, operando equipamentos de áudio e vídeo.

Pode, tambem, trabalhar com elementos e equipamentos de projeção de slides e retroprojeção.

Deve ter conhecimento de àngulos de captaçāo, luz e adequação de som à imagem. Poderá, eventualmente, fazer montagens de imagens captadas, eliminando partes desnecessárias.

ESCOLARIDADE MINIMA: $2^{\circ}$ Grau Completo, ou $1^{\circ} \mathrm{Grau}$ completo com 03 anos de experiência na função.

ÁREA DE ATUAÇĀO: Em todos os Órgãos da USP que requeiram essa habilidade

$\mathrm{CCRH}$

$07 / 03 / 95$

Presidente 
DADOS DE IDENTIFICAÇĀO

Funçāo

OPERADOR DE SOM

Grupo TÉCNICO

Inicio I A

Fim III J

DESCRIÇĀO

Opera equipamento de som de estúdio, teatro ou apresentação externa. Para tanto, segue roteiros e intervalos da produçāo, atua em seus dispositivos e efetua gravaçōes e montagens, acompanhando o andamento do trabalho. Propōe alteraçōes necessárias, para garantir a qualidade do resultado, bem como adequaçăo à atividade.

Colabora ńa manutenção de máquinas e equipamentos de trabaiho, para conservá-los em bom estado de funcionamento.

ESCOLARIDADE MINIMA: $2^{\circ}$ Grau Completo, ou $1^{\circ} \mathrm{Grau}$ Completo com 03 anos de experiência na função.

ÁREA DE ATUAÇĀO: Rádio

Presidente 
DADOS DE IDENTIFICAÇĀO

Funçāo

LOCUTOR

Grupo

TÉCNICO

Inicio I A

Fim III J

DESCRIÇĀO

Reúne habilidades vocais e de transmissâo de programação, ou apresentaçăo, tanto em estúdio como ao vivo. Essas apresentaçōes podem ser noticiosas, textuais, publicitárias ou discursivas. Para tanto, deve acompanhar uma programação definida pela produção do programa, podendo ter estilo roprio.

A clareza e exatidão da apresentaçāo é importante para a qualidade đa programação.

ESCOLARIDADE MINIMA: $2^{\circ}$ Grau Completo. Registro em Órgāo Profissional.

ÁREA DE ATUAÇĀO: Rádio.

Presidente 


\section{DADOS DE IDENTIFICAÇĀO}

Funçāo

Grupo

Início I A

Fim III J

\section{DESCRIÇĀO}

Apura, redige, revisa, relata, comenta e coordena noticias e informaçōes da atualidade e outros textos de várias naturezas, para divulgaçāo pela mídia escrita e falada. Para tanto, seleciona, revisa, prepara e distribui matérias para publicaçāo; executa a revisāo e preparação do material publicitário; pesquisa, colhe e redige noticias e informaçōes de interesse, adaptando-as à linguagem jornalistica; prépara roteiros para programas de rádio, cinema ou televisảo; redige anúncios de produtos ou serviços, objetivando transmitir informaçōes ao usuário.

Pode participar da distribuição gráfica do texto, fotografia, ou ilustraçao, de caráter jornalistico, para fins de divulgação.

ESCOLARIDADE MINIMA: $3^{\circ}$ Grau Completo em Jornalismo. Registro em Orgão Profissional.

ÁREA DE ATUAÇĀO: Coordenadoria de Comunicaçōes, Escola de Comunicaçōes, Pró-Reitoria, GR. 
$\underline{\text { ANEXO VIII - Tipos de equipamentos para produção de vídeo }}$ 
Apresentamos uma classificação dos atuais tipos de equipamentos de vídeo que considera características básicas de operação e os usos possíveis

\begin{tabular}{|c|c|c|}
\hline Tipo de equipamento & caraterísticas & utilização \\
\hline $\begin{array}{l}\text { VHS, VHS-C, } 8 \mathrm{~mm} \text {, } \\
\text { Câmeras e video cassete } \\
\text { recorder. }\end{array}$ & $\begin{array}{l}\text { Baixa qualidade de imagem prejudica } \\
\text { a edição ( } 200 \text { a } 250 \text { linhas horizontais). } \\
\text { Cores e linhas de contorno imprecisas, } \\
\text { difícil controle de contraste. Câmeras } \\
\text { com acesso limitado aos controles de } \\
\text { foco, zoom e luminosidade. Um } \\
\text { sistema de produção (uma câmera e } \\
\text { ilha de edição simples) custa em torno } \\
\text { de U\$ 5,000.00 }\end{array}$ & $\begin{array}{l}\text { Amador. } \\
\text { É possível o uso para registros } \\
\text { genéricos, os detalhes não } \\
\text { apresentam boa definição. } \mathrm{Na} \\
\text { geração de cópias perde-se muita } \\
\text { qualidade. }\end{array}$ \\
\hline $\begin{array}{l}\text { SuperVHS, Super-VHS-C, } \\
\text { Hi8 (analógicos), DV } \\
\text { (digital) } \\
\text { Câmeras, video cassete } \\
\text { recorder, sistemas de edição } \\
\text { analógico ou digital com } \\
\text { gerador de caracteres e de } \\
\text { efeitos visuais. }\end{array}$ & $\begin{array}{l}\text { Média qualidade de imagem (em torno } \\
\text { de } 400 \text { linhas horizontais). Edição de } \\
\text { áudio e vídeo com efeitos visuais } \\
\text { padronizados e interface para entrada } \\
\text { de computação gráfica simples. } \\
\text { Câmeras oferecem poucos recursos de } \\
\text { controle de cor e contraste. Um sistema } \\
\text { completo de produção (uma câmera, } \\
\text { ilha de edição completa) custa em } \\
\text { torno de U\$10,000.00.* }\end{array}$ & $\begin{array}{l}\text { Amador sofisticado. } \\
\text { É possível o registro de detalhes. A } \\
\text { edição gera uma fita matriz que } \\
\text { permite cópias de qualidade } \\
\text { razoável. }\end{array}$ \\
\hline $\begin{array}{l}\text { SuperVHS, Hi8 } \\
\text { (analógicos), DV (digital) } \\
\text { Câmera, video cassete } \\
\text { recorder, sistemas de edição } \\
\text { analógico ou digital com } \\
\text { gerador de caracteres e de } \\
\text { efeitos visuais. }\end{array}$ & $\begin{array}{l}\text { Boa/média qualidade de imagem ( } \\
\text { acima de } 400 \text { linhas horizontais. } \\
\text { Edição de áudio e vídeo com efeitos e } \\
\text { interface para entrada de computação } \\
\text { gráfica. Câmeras oferecem bons } \\
\text { recursos de controle de cor e contraste. } \\
\text { Um sistema completo de produção } \\
\text { (uma câmera com acessórios, ilha de } \\
\text { edição completa) custa em torno de U\$ } \\
30,000.00 .^{*}\end{array}$ & $\begin{array}{l}\text { Indústrias e escolas. } \\
\text { Essa linha de equipamentos, } \\
\text { chamada industrial ou semi- } \\
\text { profissional, geralmente é utilizada } \\
\text { para produção de programas de } \\
\text { treinamento e didáticos. Requerem } \\
\text { capacitação técnica para operação } \\
\text { plena dos recursos. Permite cópias } \\
\text { de boa/média qualidade. }\end{array}$ \\
\hline $\begin{array}{l}\text { Super-VHS, Betacam } \\
\text { (analógico), DVCAM, DVC } \\
\text { Pro } \\
\text { Câmeras, video cassete } \\
\text { recorder, sistemas de edição } \\
\text { analógico ou digital com } \\
\text { gerador de caracteres e de } \\
\text { efeitos visuais. }\end{array}$ & $\begin{array}{l}\text { Boa qualidade de imagem (500 a } 600 \\
\text { linhas horizontais). Edição de áudio e } \\
\text { vídeo com efeitos visuais e interface } \\
\text { para entrada de computação gráfica. } \\
\text { Câmeras oferecem bons recursos de } \\
\text { controle de cor e contraste. Um sistema } \\
\text { de produção ( uma câmera com } \\
\text { acessórios, ilha de edição completa) } \\
\text { custa em torno de U\$ 80,000.00.* }\end{array}$ & $\begin{array}{l}\text { Produtoras de vídeo. } \\
\text { Equipamentos profissionais, } \\
\text { requerem capacitação técnica para } \\
\text { operação plena dos recursos e } \\
\text { oferecem cópias de boa qualidade } \\
\text { para apresentação em televisão. }\end{array}$ \\
\hline $\begin{array}{l}\text { Super-VHS Digital, Betacam } \\
\text { (digital), DVCAM, DVC Pro } \\
\text { Câmeras, video cassete } \\
\text { recorder, sistemas de edição } \\
\text { analógico/digital com } \\
\text { gerador de caracteres e de } \\
\text { efeitos visuais em três } \\
\text { dimensões. }\end{array}$ & $\begin{array}{l}\text { Ótima qualidade de imagem (em torno } \\
\text { de } 750 \text { linhas horizontais). Edição de } \\
\text { áudio e vídeo com efeitos visuais e } \\
\text { interface para entrada de computação } \\
\text { gráfica. Câmeras oferecem ótimos } \\
\text { recursos de controle de cor, linhas de } \\
\text { contorno, e contraste. Um sistema de } \\
\text { produção ( uma câmera com } \\
\text { acessórios, ilha de edição completa) } \\
\text { custa em torno de U } \$ 250,000.00 .^{*}\end{array}$ & $\begin{array}{l}\text { Televisão, produtoras de vídeo. } \\
\text { Equipamentos profissionais, } \\
\text { requerem capacitação técnica para } \\
\text { operação plena dos recursos e } \\
\text { oferecem cópias de ótima } \\
\text { qualidade para televisão. É } \\
\text { utilizado para edição e acabamento } \\
\text { de filmes publicitários. }\end{array}$ \\
\hline
\end{tabular}

* (custo estimado em cotações no mercado norte-americano, indicado apenas para uma referência da escala de valores, não estão inclusos os custos de importação e impostos). 
Universidade de São Paulo

Programa de Pós-Graduação em Ciências da Comunicação

PRODUÇÃO AUDIOVISUAL NA UNIVERSIDADE DE SÃO PAULO

Domingos Luiz Bargmann Netto

São Paulo - SP

Maio de 2000 